\title{
Living benthic foraminifera: biogeographical distributions and the significance of rare morphospecies
}

\author{
JOHN W. MURRAY \\ National Oceanography Centre Southampton, University of Southampton Waterfront Campus, European Way, Southampton SO14 3ZH, UK \\ *Corresponding author (e-mail jwm1@noc.soton.ac.uk)
}

\begin{abstract}
Previous studies have investigated regional distribution but this is the first attempt to investigate the global biogeographical distribution of individual morphospecies of living/stained smaller benthic foraminifera. From 8032 samples collected between 1952 and 2011 data have been gathered on the relative abundance of $>120$ species in five major environments ranging from marsh to deep sea. There is a spectrum of six groups of species with abundance ranging from very high (Group 1) to extremely low (Group 6). In the latter species abundance never reaches $10 \%$ of an assemblage and, in many cases, it is only $1-2 \%$. Individual species are shown to occupy a range of environments with very few being confined to a single environment (usually either marsh or deep sea). Some species occur in several oceans while others are confined to just one. There is no correlation between species abundance and being either widely or narrowly distributed. Propagules are the most likely mechanism of dispersal but some narrowly distributed species may not produce them. Generalists may be widely or narrowly distributed but opportunists are likely to be widely distributed. The rare species of Group 6 contribute to high diversity in shelf and deep-sea assemblages. These species may be adapted to minor differences in microhabitats induced by disturbance and patchy food supply. Patterns of biogeography have application to ecology, palaeoecology and taxonomy. J. Micropalaeontol. 32(1): 1-58, January 2013.
\end{abstract}

SUPPLEMENTARY MATERIAL: Taxonomy and details of types; sources of data (N1-N55) additional to that of Murray (2006); and sources of data for Figures 4-95 plus other agglutinated and hyaline taxa are available at www.geolsoc.org.uk/SUP18576

KEYWORDS: rare, biogeography, disjunct, propagules

\section{BACKGROUND TO THE STUDY}

In the early 2000 s the author became interested in the distribution of rare morphospecies of benthic foraminifera. Rare species must have some ecological significance as they are key contributors to high diversity. However, it soon became apparent that the topic could not be pursued without gathering all the data on species occurrences and that took a lot of time and effort. When those data had been gathered it led to the writing of the book on ecology (Murray, 2006) but the focus was on assemblages and common species rather than rare species. Constraints of time and the size of the book agreed with the publishers meant that consideration of rare species had to be saved for a future date.

In 2011 the author decided to go through the post-book literature in order to complete the survey of living occurrences to that date. Initial results from the analysis of abundance and biogeographical distributions of a few species yielded a number of surprises. For example, some species thought to be universally rare have occasional occurrences of higher abundance. Rare, common and abundant are relative terms (without any numerical definition) for describing segments of a continuous series of occurrences. It became obvious that defining rarity could best be achieved by comparing the numerical abundance and biogeography of a spectrum of species from this continuous series. Although it is already known that even an abundant species is rare towards the margins of its distribution this new analysis reveals the extent of that rarity in a way that has not previously been possible.

\section{INTRODUCTION}

It is a paradox that rare species are common.

Who can explain why one species ranges widely and is very numerous, and why another allied species has a narrow range and is rare? Yet these relations are of the highest importance, for they determine the present welfare and, as I believe, the future success and modification of every inhabitant of this world.

Thus wrote Darwin in 1859 in his Introduction (final paragraph) to the Origin of Species. Although much has since been written on this topic very few answers have emerged, as can be seen from the following comments. 'Understanding the causes and consequences of rarity is a problem of profound significance because most species are uncommon to rare, and rare species are generally at greater risk to extinction' (Hubbell, 2001, p. 30). Among the key concepts discussed by Hayek \& Buzas (2010, p. 2) in their valuable overview of the statistics of surveying natural populations is that 'All organisms have the potential to reproduce at a geometrical rate, and hence to populate the world'. However, we know from observation that this rate of expansion is never fully realized not even in abundant species. But the reasons for this are largely unknown.

In spite of the fact that the majority of species of all groups of animals and plants are rare many ecologists seem to consider rarity to be anomalous (e.g. Angel, 1995; Kunin, 1997). They seek special explanations for rarity and for how rare species manage to survive. This is partly because some rare species are threatened by the activities of humans so research on rarity is funded for its potential in planning conservation. Indeed, much of the literature on rarity is either conservation-orientated, especially with respect to land plants, certain land animals and marine fish stocks, or is theoretical (Hubbell, 2001). But is rarity an anomaly? Looking at the matter objectively and without preconceptions, if most species are rare then that is the norm and may require no special explanation. The unusual species are those that show local geographical or temporal abundance. Perhaps we should be less concerned with 
how or why rare species survive and more concerned with determining why only some species become so abundant.

The differences between rare and common morphospecies may be better understood by analysing a group of organisms that has been widely studied and which is not in the public eye so there are no concerns over loss of species or of conservation. Benthic foraminifera fulfil this role. Their distribution is reasonably well known (Murray, 2006; 2007) based on an analysis of 2.4 million living (stained) individuals in $\sim 7300$ samples of surface sediment. They occur from the intertidal zone to the deepest ocean trench and from pole to pole. There are $\sim 2140$ recorded species of which $\sim 33 \%$ have abundances $>10 \%$ and $\sim 67 \%$ are of minor importance. Yet, with the exception of being used in calculations of species diversity, rare species are largely ignored in ecological studies of benthic foraminifera. Perhaps we should give them more attention as they may be more ecologically significant than we have hitherto realized. The aim of this paper is to open up the topic for consideration and debate.

A choice had to be made as to whether to use data on live (stained) or dead forms. The author favours the former because dead distributions have always been subject to post-mortem change, some of which may be very significant. On a local scale there may be transport from one environment to another (e.g. from marsh to adjacent lagoon) but this causes only minor anomalies. However, some processes are much more wide-ranging. For example, on continental shelves there are faunas relict from former lower sea-level (e.g. Gulf of Mexico drowned reefs, Ludwick \& Walton, 1957; European shelf, Blanc-Vernet, 1969) and there is significant downslope mass-flow transport of sediment in submarine canyons from shelf and upper slope to continental rise and abyssal plains (leading to the deposition of turbidites) and also mass slides on continental margins (e.g. Storegga slide (Bugge et al., 1987) involving Tertiary to Quaternary sediments). In some areas Neogene and older foraminifera are reworked from erosion of cliffs or submarine outcrops (e.g. Uchio, 1960). In the author's opinion it is better to have reliable data from fewer locations than to include data of such uncertain reliability from dead or relict distributions.

This study is the first attempt to examine the global biogeography and abundance of individual living/stained morphospecies. Previous studies of foraminiferal biogeography have been concerned with the recognition of faunal provinces based on assemblages of morphospecies (including live and dead) mainly through the detailed work of Buzas and Culver (see Culver \& Buzas, 1999 and references therein; review in Murray, 2006, pp. 257-260) and the only global analyses of individual morphospecies have been of shallow-water larger foraminifera (Belasky, 1996). The internet World register of Marine Species (WoRMS) lists the distribution (presence/absence) of modern species based on any type of data: live, dead, total without making any distinctions between them and without any information on abundance. Using data on 938 common morphospecies from Murray (1991), Pawlowski \& Holzmann (2008) determined that more than 50\% show a restricted distribution from 1-10 biogeographical regions. Only 20 of the 25 most widely distributed morphospecies occur in more than 5 regions. Biogeographical studies are also being made on phylotypes (via molecular genetics; e.g. Hayward et al. 2004; Pawlowski et al., 2007; Pawlowski \& Holzmann, 2008; Schweizer et al., 2011). These are fundamentally altering our concept of some morphospecies and throwing new light on biogeography.

\section{METHODS}

\section{Definition of terms}

Several of the terms used in ecological and biogeographical studies are relative with no numerical definition. The definitions used in this study are presented here.

- Rare species: one that is infrequently encountered. Most truly rare species have a very low relative abundance of $<1 \%$ of an assemblage.

- Low abundance: generally any species forming $<5 \%$ of an assemblage and very low abundance for $<1 \%$ of an assemblage.

- Biogeographical distributions: two ill-defined terms have been used to define broad extremes: 'cosmopolitan' for widely distributed species and 'endemic' for those species restricted to a limited area. In a critical review of the concept of endemism, Anderson (1994) pointed out that the term means different things to different people (e.g. biogeographers, evolutionists, those studying diseases). There are many factors that control the restriction of a species to an area: the size of the area under consideration, the size of the organisms and their taxonomic status, changes in distribution through time (seasonal, annual, geological), variability or stability of the environment, etc. Because there is no consensus on the precise definition of these terms they are avoided here. Instead the terms 'wide' and 'narrow' are used for the two extremes of distribution. The widest distribution is occurring in all oceans. The narrowest distribution is occurring in part of a single ocean.

- Major environments:

- Marsh/mangal have been separated from other marginal marine environments because they are permanently vegetated with higher land plants and are distinctive.

- Marginal marine includes estuaries and lagoons and their non-vegetated intertidal zones; the Baltic is considered to be marginal marine because it is brackish.

- Fjord relates to glacially deepened valleys that are connected to the sea but invariably having shallow sills that restrict the exchange of deep marine water with the adjacent shelf. Fjords are restricted to higher latitudes.

- Shelf includes environments on the continental shelf including some deeper enclosed basins resulting from glacial erosion. The shelf break dividing the shelf from the continental slope varies in depth according to regional geology but is broadly in the depth range $100-200 \mathrm{~m}$. A depth of $200 \mathrm{~m}$ is taken as the deeper limit of the shelf.

- The deep sea $(>200 \mathrm{~m})$ includes the continental slope and rise, the abyssal plains and trenches. It also includes the borderland basins of the California margin of the USA.

- Salinity. No unit is given. Measurements from older literature are based on chemical methods (ppt, \%o) and, more recently, by the conductivity ratio (practical salinity unit, psu, or more correctly Practical Salinity Scale, PSS; see Simpson \& Sharples, 2012).

\section{Selection of species}

The morphospecies chosen for biogeographical analysis include many forms selected because they are easily identified (e.g. Patellina corrugata, Spirillina vivipara) but also several species of a single genus for comparison (e.g. Fissurina, Pullenia). They span a range of relative abundance from high to very low, and a range of distribution from wide to narrow. It has not been possible 
to check the identification of every species since not all authors provide illustrations and rarer species are commonly not illustrated. The taxa are listed in Supplementary Publication table 1 together with the original name, the type locality, type level and age. No attempt has been made to plot the occurrences of any monothalamous organic or agglutinated taxa.

\section{Samples}

Every synthesis depends on the available published data. The author is unaware of any study of benthic foraminifera that has been designed specifically to target rare species. All distributional studies concentrate on the common forms. In those cases where there is only a single survey of the fauna of an area (most studies), it can be regarded as a preliminary study. Only rarely is there repeat sampling of an area over a period of time in order to track temporal changes.

The history of development of sampling methods has been reviewed by Schönfeld (2012). The almost universally utilized staining method for recognizing 'living' foraminifera uses rose Bengal to stain protoplasm red (Walton, 1952; see reviews by Bernhard, 2000 and Murray \& Bowser, 2000 for discussion of problems and solutions). In the six decades since 1952 hundreds of surveys of the abundance and local distribution patterns of stained ('living') foraminifera have been carried out. Most are single surveys taken over a period of days and never repeated. Few studies include replicate sampling. Apart from affecting abundant taxa the time-scale of sampling must also affect rare taxa and this may be particularly significant as regards the recording of short-term, localized blooms of abundance resulting from infrequent reproduction.

There is a range both of sieve size used and number of individuals counted in each sample. Examples of the range of sieve size are given by Schönfeld (2012, table 1). The commonly used size fraction for marsh, marginal marine and shelf samples is $>63 \mu \mathrm{m}$ but for fjords and the deep sea many authors use $>125$ or $>150$ or even occasionally $>250 \mu \mathrm{m}$. It is not possible to assess the effect of this on the results discussed here except to point out the obvious fact that small tests will be most commonly overlooked when larger size fractions are studied. Some samples are quantitative so the absolute number of individuals per unit area of sea floor and volume of sediment are known; others are qualitative with no information on either area or volume so only relative abundance $(\%)$ can be determined. Quantitative samples are more readily taken in intertidal settings. They can also be taken in cohesive (usually muddy) sediments from the shelf or deep sea using multicorers or box corers (see Schönfeld, 2012). Coarse, non-cohesive sediments are not easily sampled using corers. The size of the count $(n)$ and the number of species encountered $(S)$ are linked to the species diversity of the sample. Another aspect of sample size is whether a given sample is large enough to be representative of the species present. By definition, rare species (i.e. those infrequently sampled) have low absolute and relative abundance $(<1 \%)$. Hayek \& Buzas $(2010$, pp. 144-145) demonstrate that the confidence limits of very low abundances 'contribute nothing to the characterization of the flora or fauna' because of the degree of fit of the Normal approximation. This improves as $p$ (estimated abundance) comes closer to 0.5 . Furthermore, they conclude (pp. 148-9) 'if we were to apply statistical theory, we could say that we would never be able to sample anywhere near all the rare species'. In other words, the recorded data are incomplete and there is nothing we can do about it. Although this generalization is true for a single sample a suite of
Table 1. The six categories of abundance based on the proportion of samples having species abundances $>10 \%$ in an assemblage.

\begin{tabular}{lc}
\hline Group & $\%$ of samples \\
\hline 1 & $>40$ \\
2 & $20-40$ \\
3 & $10-20$ \\
4 & $2-10$ \\
5 & $0.1-2$ \\
6 & 0 \\
\hline
\end{tabular}

samples from a restricted area will provide a more representative record of rare species, albeit still incomplete.

\section{Counting/census data}

It would be impractical to use only standing crop data in an analysis of rare species as the pool of information would be very limited. Therefore, relative abundance data (\%) are the basis for this study but they are supplemented with information on standing crop (normally number of individuals per $10 \mathrm{~cm}^{3}$ sediment) where that is available. Nevertheless, where the standing crop of a sample has been determined, the number of individuals of each species can be calculated from the relative abundance. For a standing crop of 1000 per unit area, $1 \%=10$ individuals. As it is relatively uncommon for a standing crop to reach 1000 per $10 \mathrm{~cm}^{3}$ sediment, it follows that almost all $<1 \%$ occurrences invariably represent few individuals.

\section{Sources and treatment of data}

Altogether, data on 8032 samples have been compiled (using only those with a count $>50$ individuals; choosing a higher count would have eliminated a large number of samples). Virtually all the counting/census information in publications from 1952 (introduction of staining method) to June 2005 is available in spreadsheets in Murray (2006, web appendix tables WA-1-WA-219; 7276 samples of living assemblages). There are additional new data from papers published since 2005 (Supplementary Publication table 2, 756 samples). Where authors have used separate size fractions from the same sample these are treated as separate samples because unequal parts of the different fractions were often counted (S. Hess, pers. comm., 2011) so a true average cannot be calculated.

For each species, all the abundance data have been organized by major environment and geographical area. Zero occurrences have been ignored in calculating mean values.

Five major environments are recognized: marsh/mangal, marginal marine, fjord, shelf, deep sea, as defined above.

A species abundance $>10 \%$ in an assemblage is the criterion for defining the six categories of abundance (Table 1).

\section{Biogeographical template}

The scope of data is shown on the world map (Fig. 1). In order to show both biogeography and environment it is much more convenient to plot species distributions on a template (Fig. 2). This allows more detail to be recorded in less space.

\section{RESULTS}

\section{Summary of numerical data}

The complete dataset comprises 8032 samples. The 7276 samples of living assemblages considered by Murray (2006) are distributed 


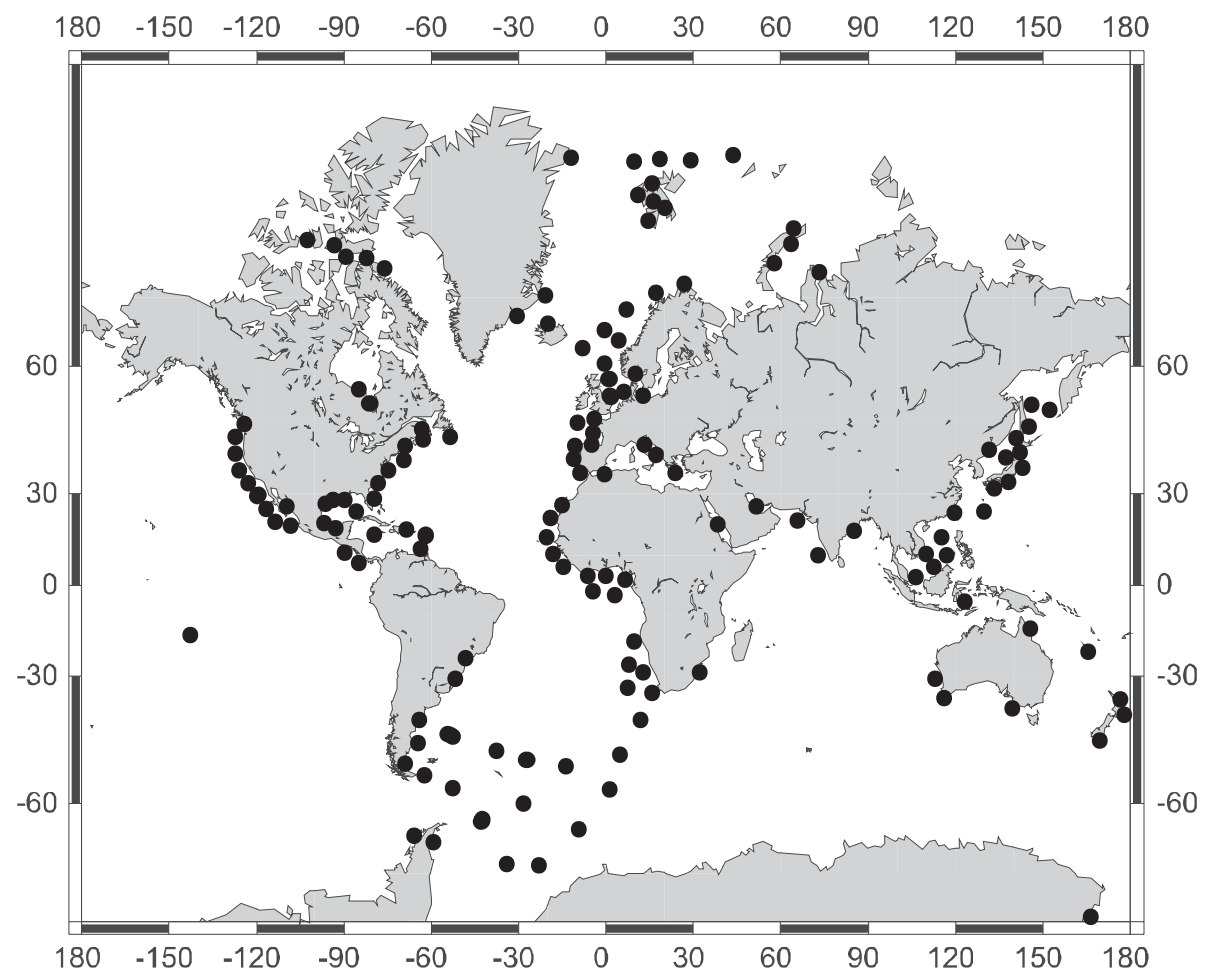

Fig. 1. Map broadly indicating the distribution of data by means of dots.

between environments in the following way: $52 \%$ marginal marine, $5 \%$ fjords, $31 \%$ continental shelf and $12 \%$ deep sea. The geographical distribution of species which are dominant or subsidiary (having $>10 \%$ abundance) is shown in a series of diagrams in the book. Species that never reach $10 \%$ abundance are omitted from the diagrams but are nevertheless included in the web appendix tables. There is a strong bias towards the North Atlantic with very little information from the Pacific in relation to its great size (mainly from western USA and Japan) or the Indian Ocean which has hardly been explored. The 756 additional samples from 2005-2011 show the same geographical bias and the distribution by environments is broadly similar to that of the book data: $37 \%$ marginal marine, $1 \%$ fjords, $43 \%$ continental shelf and $18 \%$ deep sea.

Summary information on the distribution of abundance in the complete dataset and between environments is given in Table 2 . The taxa are listed alphabetically to make it easier to find a species. The data are presented in the following way, taking the example of Ammoastuta inepta. This species occurs in 46 samples which make up $0.6 \%$ of the 8032 samples. There are 13 samples where the species abundance is $>10 \%$ and these make up $28.3 \%$ of the samples in which this species is present. Therefore, $71.7 \%$ of the occurrences have a species abundance of $<10 \%$. There are 2 samples with a species abundance of $<1 \%$ and these make up $4.3 \%$ of the occurrences of this species.

All species have some abundances $<1 \%$ even if they are locally highly abundant. The section of Table 2 labelled ' $\%$ samples in each major environment' shows the distribution of samples between major environments. Perhaps the most surprising feature of these results is the number of environments over which some species are spread; in many cases it is 3 or 4 out of the 5 divisions. The only species confined to a single environment are Balticammina pseudomacrescens (marsh), Guttulina problema,
Reussella spinulosa, Vasiglobulina (shelf), and 12 deep sea species: Astrononion echolsi, Fursenkoina apertura, Gyroidina altiformis, G. polia, Laticarinina pauperata, Nuttallides pusillus, $N$. umboniferus, Oridorsalis sidebottomi, O. tener, Osangularia culter, Pullenia salisburyi and P. simplex. None of the taxa studied is confined to either marginal marine or fjord environments.

Statistics have been assembled on 31 agglutinated, 2 porcelaneous and 99 hyaline taxa (Table 3). The overall mean abundance is not commonly $>10 \%$ in the species selected for study. The maximum abundances refer to the single highest value in each environment. Nevertheless, some maximum abundances of $>10 \%$ are found even in species having a low mean abundance.

\section{Categories of species abundance}

A species abundance in an assemblage of $>10 \%$ is the criterion for defining the six categories in Tables 1 and 4 . The proportion of occurrences $(\%)$ relates to the number of samples in which the species is present. At the high extreme, Group 1, the listed species have abundances $>10 \%$ in $>40 \%$ of the occurrences. In the case of Group 6 no samples have $>10 \%$ abundance for any of the species listed. Graphical plots of species abundance against number of occurrences show different patterns from group to group (Fig. 3). The curves of rare species in Group 6 are flat along the $\mathrm{x}$-axis whereas the very abundant forms in Group 1 have a significant number of high values.

\section{Biogeography and comments on species ecology}

Details of the numerical distributions are given in Tables 2 and 3. In order to improve the flow of the text the notes and biogeographical plots of individual taxa (Figs 4-95) are given in the Appendix. The sources of data used to compile these figures are given in Supplementary Publication tables 3-18. 


\begin{tabular}{|c|c|c|c|c|c|c|}
\hline$\sim$ lat. N-S & Area & Marsh & Marginal marine & Fjords & Shelf & Deep sea \\
\hline & Arctic Ocean & & 36 & $95-98$ & 36,111 & 111,212 \\
\hline $70-60$ & N \& W Norway & & \multicolumn{3}{|c|}{$99,100, \mathrm{~N} 19, \mathrm{~N} 20$} & 193, N41 \\
\hline 65 & Iceland & & & & 191 & 191,192 \\
\hline $55-59$ & S Scandinavia/Baltic & 1 & $37,112, \mathrm{~N} 10, \mathrm{~N} 11$ & $101-106$ & 113 & \\
\hline 56 & Seas around UK & $1-3, \mathrm{~N} 1$ & $38-46$ & 107 & $40,114-120,192$ & \\
\hline $43-45$ & Biscay & 4,5 & $47-49$ & & $121,122, \mathrm{~N} 25, \mathrm{~N} 26$ & 199,N26,N42-N46 \\
\hline 39 & Portugal & N5 & N5 & & $123,194, \mathrm{~N} 47$ & $123,194-196, \mathrm{~N} 47-\mathrm{N} 49$ \\
\hline 43 & W Mediterranean & & 90 & & $90, \mathrm{~N} 27, \mathrm{~N} 28$ & 204, N50-N51 \\
\hline 45 & E Mediterranean & 6 & $50,51, \mathrm{~N} 12,124$ & & $124-130, \mathrm{~N} 29$ & 127 \\
\hline 20 & NW Africa & & & & 131,132 & 131,200 \\
\hline 0 & Gulf of Guinea & & & & 133 & 133,201 \\
\hline $10-30$ & S Atlantic & & & & & 202 \\
\hline $35-56$ & S Atlantic & & & & & 203 \\
\hline
\end{tabular}

\begin{tabular}{|c|c|c|c|c|c|c|}
\hline$\sim$ lat. N-S & Area & Marsh & Marginal marine & Fjords & Shelf & Deep sea \\
\hline 70 & E Greenland & & & 93,94 & & 197,198 \\
\hline 73 & Arctic Canada & & & & 134,135 & 134,135 \\
\hline $50-43$ & Canada & $7-13, \mathrm{~N} 2$ & $52-54$ & & $53,136,137$ & \\
\hline $45-40$ & E USA & $14-16$ & $55-57,59,60$ & & 138,139 & 205,206 \\
\hline $40-25$ & E USA & $17-20,62, \mathrm{~N} 3, \mathrm{~N} 4$ & $58,61-66$ & & $140-142$ & N52 \\
\hline 30 & N Gulf of Mexico & $21-23$ & $67-69,91,92, \mathrm{~N} 13$ & & $91,92,143-146$ & 207 \\
\hline $25-18$ & S Gulf of Mexico & & $70-72$ & & & \\
\hline $18-12$ & Caribbean Sea & & $73-76,78$ & & $147-149, \mathrm{~N} 30$ & \\
\hline 5 & French Guiana & 24 & & & & \\
\hline $24-31$ & Brazil & 25,26 & 79,80 & & & \\
\hline $38-54$ & Argentina & 25 & 81 & & 150,151 & 151 \\
\hline 58 & Scotia Sea & & & & & 214 \\
\hline 67 & Weddell Sea & & & & & $173,213,215,216$ \\
\hline
\end{tabular}

REST OF WORLD

\begin{tabular}{|c|c|c|c|c|c|c|}
\hline$\sim$ lat. & Area & Marsh & Marginal marine & Fjords & Shelf & Deep sea \\
\hline 48 & Pacific Canada & 27,28 & & & & \\
\hline $47-33$ & Pacific USA & 27,29 & $82-84,152, \mathrm{~N} 14$ & & 153 & $154-160,208,209$ \\
\hline 28 & Baja California & $27,30,31$ & 30,31 & & 153 & 160 \\
\hline 12 & El Salvador-Nicaragua & & & & 162 & 162, N31 \\
\hline 35 & Korea \& Japan & 32,86 & $85, \mathrm{~N} 15$ & & 163-167,181,N33 & 163-166, N40,210 \\
\hline $\mathrm{x}$ & S China Sea & & 86 & & N32 & $211, \mathrm{~N} 53$ \\
\hline 5 & Banda Sea & 35 & & & & \\
\hline 40 & New Zealand & $33,34, \mathrm{~N} 6$ & & & 169 & \\
\hline \multirow[t]{2}{*}{18} & Atolls & & & & $170, \mathrm{~N} 34$ & \\
\hline & Red Sea/Arabian Gulf & & $182-183,185$ & & 184 & \\
\hline 10 & Indian Ocean & & 88 & & 88,171 & N54,N55 \\
\hline 28 & S Africa & & 89 & & & \\
\hline $15-30$ & Australia & N7 & 168 & & & \\
\hline 65 & Antarctic & & & & 172,217 & $217-219$ \\
\hline
\end{tabular}

Fig. 2. Template for plotting biogeography by environment. The numbers refer to the data spreadsheets (see Supplementary Publication table 2).

\section{DISCUSSION}

'Explaining observed patterns of densities by environmental variables is much more difficult than their recognition' (Buzas et al., 1977, p. 56).

No synthesis of data collected over six decades can provide an instantaneous 'snapshot' of distribution or abundance; at best they give an overview. Nevertheless, some clear patterns are evident:

Although all species show low abundance (are rare) in part of their range, only some species also show high abundance (Fig. 3).

For the first time it is shown that species thought to be typical of one environment are also found quite commonly in other environments (Tables 2, 3).

There is a mix of disjunct (discontinuous) and continuous biogeographical distributions (Figs 4-95).

\section{Patterns of abundance}

Six categories of abundance are distinguished (Fig. 3, Tables 1, 4). It is inevitable that the typical representatives of Group 1 are from low diversity assemblages because only where the number of species is low is it likely that high relative abundances can be reached. What is surprising is that even in species normally considered to be abundant the proportion having a relative abundance of $>10 \%$ is modest. For example, this value is reached in only $45 \%$ of samples containing Miliammina fusca and $41 \%$ for Stainforthia fusiformis (both in Group 1). Textularia earlandi, a Group 4 species which is widespread (Fig. 27) ), has only 5\% of its occurrences $>10 \%$ while $50 \%$ of its occurrences have relative abundances of $<1 \%$. As discussed in the Introduction, many ecologists regard rarity as an anomaly whereas these results clearly show that for benthic foraminifera it is quite normal.

\section{Environmental spread of species}

The divisions between major environments are arbitrary and anthropogenic (e.g. selecting a specific depth as the boundary between shelf and slope) whereas in nature there is a continuum between adjacent environments. Therefore, it is not surprising that individual species do not respect these boundaries. Thus, marginal marine species may extend their distributions on to marshes or inner continental shelf, and shelf and deep-sea species may overlap. However, it is very surprising that so many species occur in four of the major environments (Table 2, e.g. Ammobaculites agglutinans, Ammoscalaria 
Table 2. The number of samples and their proportions in the whole dataset.

\begin{tabular}{|c|c|c|c|c|c|c|c|c|c|c|c|c|c|}
\hline \multirow[b]{2}{*}{ Species } & \multicolumn{7}{|c|}{ Occurrences } & \multirow[b]{2}{*}{$\begin{array}{l}\text { Abundance } \\
\text { Group }\end{array}$} & \multicolumn{5}{|c|}{$\%$ of samples in each major environment } \\
\hline & $\begin{array}{l}\text { Samples } \\
\text { with sp. }\end{array}$ & $\begin{array}{c}\% \text { all } \\
\text { samples }\end{array}$ & $\begin{array}{c}\text { Samples } \\
\text { abund } \\
>10 \%\end{array}$ & $\begin{array}{l}\% \text { samples } \\
\text { abund } \\
>10 \%\end{array}$ & $\begin{array}{l}\% \text { samples } \\
\text { abund } \\
<10 \%\end{array}$ & $\begin{array}{c}\text { Samples } \\
\text { abund } \\
<1 \%\end{array}$ & $\begin{array}{c}\text { \% samples } \\
\text { abund } \\
<1 \%\end{array}$ & & Marsh & $\begin{array}{l}\text { Marginal } \\
\text { marine }\end{array}$ & Fjord & Shelf & $\begin{array}{l}\text { Deep } \\
\text { sea }\end{array}$ \\
\hline \multicolumn{14}{|l|}{ Agglutinated } \\
\hline Ammoastuta inepta & 46 & 0.57 & 13 & 28.26 & 71.74 & 2 & 4.35 & 2 & 56.52 & 41.30 & absent & 2.17 & absent \\
\hline Ammobaculites agglutinans & 228 & 2.84 & 10 & 4.39 & 95.61 & 102 & 44.74 & 4 & absent & 4.82 & 0.88 & 26.75 & 67.54 \\
\hline Ammobaculites balkwilli & 103 & 1.28 & 10 & 9.71 & 90.29 & 45 & 43.69 & 4 & 1.94 & 93.20 & 4.85 & absent & absent \\
\hline Ammobaculites dilatatus & 92 & 1.15 & 5 & 5.43 & 94.57 & 30 & 32.61 & 4 & 38.04 & 47.83 & absent & 14.13 & absent \\
\hline Ammobaculites exiguus & 89 & 1.11 & 17 & 19.10 & 80.90 & 26 & 29.21 & 3 & 68.54 & 7.87 & absent & 23.60 & absent \\
\hline Ammobaculites filiformis & 75 & 0.93 & 2 & 2.67 & 97.33 & 38 & 50.67 & 4 & absent & absent & absent & 1.33 & 98.67 \\
\hline Ammoscalaria runiana & 114 & 1.42 & 7 & 6.14 & 93.86 & 45 & 39.47 & 4 & 1.75 & 83.33 & 9.60 & 5.26 & absent \\
\hline Ammotium salsum & 620 & 7.72 & 267 & 43.06 & 56.94 & 66 & 10.65 & 1 & 51.77 & 40.32 & absent & 7.90 & absent \\
\hline Arenoparella mexicana & 214 & 2.66 & 50 & 23.36 & 76.64 & 37 & 17.29 & 2 & 84.11 & 15.89 & absent & absent & absent \\
\hline Balticammina pseudomacrescens & 337 & 4.20 & 265 & 78.64 & 21.36 & 4 & 1.19 & 1 & 100.00 & absent & absent & absent & absent \\
\hline Eggerella advena & 517 & 6.44 & 103 & 19.92 & 80.08 & 277 & 53.58 & 2 & 1.16 & 9.28 & 1.35 & 62.28 & 25.92 \\
\hline Eggerella europea & 18 & 0.22 & 0 & 0.00 & 100.00 & 16 & 88.89 & 6 & absent & absent & 16.67 & 83.33 & absent \\
\hline Eggerelloides medius & 110 & 1.37 & 24 & 21.82 & 78.18 & 11 & 10.00 & 2 & absent & absent & 24.55 & 73.64 & 1.82 \\
\hline Eggerelloides scaber & 846 & 10.53 & 141 & 16.67 & 83.33 & 231 & 27.30 & 3 & absent & 14.30 & 16.78 & $\mathbf{5 9 . 5 7}$ & 9.34 \\
\hline Gaudryina exilis & 98 & 1.22 & 4 & 4.08 & 95.92 & 36 & 36.73 & 4 & 21.40 & 61.20 & absent & 17.30 & absent \\
\hline Gaudryina pauperata & 32 & 0.40 & 1 & 3.13 & 96.88 & 10 & 31.25 & 4 & 56.30 & 21.90 & absent & 18.75 & 3.13 \\
\hline Glomospira gordialis & 155 & 1.93 & 1 & 0.65 & 99.35 & 96 & 61.94 & 5 & 0.64 & 17.95 & 0.64 & 35.90 & 44.23 \\
\hline Haplophragmoides bradyi & 314 & 3.91 & 15 & 4.78 & 95.22 & 143 & 45.54 & 4 & absent & absent & 8.60 & 28.66 & 62.74 \\
\hline Haplophragmoides shallow spp. & 402 & 5 & 119 & 29.60 & 70.40 & 45 & 11.19 & 2 & 92.79 & 6.97 & absent & 0.25 & absent \\
\hline Jadammina macrescens & 818 & 10.18 & 363 & 44.38 & 55.62 & 118 & 14.43 & 1 & 81.42 & 17.97 & 0.12 & 0.49 & absent \\
\hline Miliammina fusca & 1807 & 22.50 & 808 & 44.71 & 55.29 & 173 & 9.57 & 1 & 56.89 & 40.01 & 1.77 & 1.33 & absent \\
\hline Reophax moniliformis & 256 & 3.19 & 17 & 6.64 & 93.36 & 123 & 48.05 & 3 & 11.72 & 76.56 & 0.39 & 11.33 & absent \\
\hline Reophax nana & 170 & 2.12 & 15 & 8.82 & 91.18 & 84 & 49.41 & 4 & 19.41 & 71.18 & absent & 9.41 & absent \\
\hline Siphotrochammina lobata & 56 & 0.70 & 14 & 25.00 & 75.00 & 4 & 7.14 & 2 & 82.10 & 17.90 & absent & absent & absent \\
\hline Textularia earlandi & 607 & 7.56 & 33 & 5.44 & 94.56 & 305 & 50.25 & 4 & 13.51 & 34.43 & 6.59 & 28.83 & 16.64 \\
\hline Tiphotrocha comprimata & 412 & 5.13 & 194 & 47.09 & 52.91 & 19 & 4.61 & 1 & 98.30 & 1.70 & absent & absent & absent \\
\hline Trochammina inflata & 1169 & 14.55 & 548 & 46.88 & 53.12 & 166 & 14.20 & 1 & 81.42 & 17.97 & 0.12 & 0.49 & absent \\
\hline Trochammina lobata & 21 & 0.26 & 0 & 0.00 & 100.00 & 7 & 33.33 & 6 & absent & absent & absent & 95.20 & 4.80 \\
\hline Trochammina pacifica & 197 & 2.45 & 18 & 9.14 & 90.86 & 84 & 42.64 & 4 & absent & 6.60 & absent & 44.67 & 48.73 \\
\hline $\begin{array}{l}\text { Uszbekistania charoides } \\
\text { Porcelaneous }\end{array}$ & 150 & 1.87 & 0 & 0.00 & 100.00 & 93 & 62.00 & 6 & absent & 6.67 & absent & 15.33 & 78.00 \\
\hline Cornuspira involvens & 428 & 5.33 & 15 & 3.50 & 96.50 & 253 & 59.11 & 4 & 28.97 & 13.32 & 3.97 & 31.78 & 21.96 \\
\hline Pyrgo williamsoni & 77 & 0.96 & 1 & 1.30 & 98.70 & 43 & 55.84 & 5 & absent & 1.30 & 32.47 & 31.17 & 35.06 \\
\hline Hyaline & & 0 & & & & & & & & & & & \\
\hline Amphicoryna & 180 & 2.24 & 3 & 1.67 & 98.33 & 114 & 63.33 & 5 & absent & absent & absent & 51.67 & 48.33 \\
\hline Astacolus & 52 & 0.65 & 0 & 0.00 & 100.00 & 43 & 82.69 & 6 & absent & absent & 5.77 & 67.31 & 26.92 \\
\hline Asterigerina carinata & 70 & 0.87 & 12 & 17.14 & 82.86 & 17 & 24.29 & 3 & absent & 61.43 & absent & 38.57 & absent \\
\hline Asterigerinata adriatica & 23 & 0.29 & 2 & 8.70 & 91.30 & 5 & 21.74 & 4 & absent & absent & absent & 100.00 & absent \\
\hline Asterigerinata mamilla & 150 & 1.87 & 2 & 1.33 & 98.67 & 93 & 62.00 & 5 & absent & 14.67 & absent & 84.67 & 0.67 \\
\hline Astrononion echolsi & 46 & 0.57 & 0 & 0.00 & 100.00 & 15 & 32.61 & 6 & absent & absent & absent & absent & 100.00 \\
\hline Astrononion gallowayi & 151 & 1.88 & 19 & 12.58 & 87.42 & 54 & 35.76 & 3 & absent & absent & 34.44 & 39.74 & 25.83 \\
\hline Astrononion sidebottomi & 64 & 0.80 & 1 & 1.56 & 98.44 & 37 & 57.81 & 5 & absent & absent & absent & 100.00 & absent \\
\hline Astrononion stelligerum & 39 & 0.49 & 0 & 0.00 & 100.00 & 26 & 66.67 & 6 & absent & 2.56 & absent & 79.49 & 17.95 \\
\hline Astrononion all spp. & 361 & 4.49 & 21 & 5.82 & 94.18 & 161 & 44.60 & 4 & absent & 1.94 & 14.13 & 45.71 & 38.23 \\
\hline Buliminella elegantissima & 887 & 11.04 & 109 & 12.29 & 87.71 & 373 & 42.05 & 3 & 1.80 & 56.26 & 0.23 & 40.92 & 0.79 \\
\hline Dentalina spp. & 228 & 2.84 & 0 & 0.00 & 100.00 & 178 & 78.07 & 6 & absent & 0.44 & 5.26 & 38.16 & 56.14 \\
\hline Ehrenbergina & 72 & 0.90 & 4 & 5.56 & 94.44 & 29 & 40.28 & 4 & absent & 1.39 & absent & 33.33 & 65.28 \\
\hline Fissurina laevigata & 132 & 1.64 & 1 & 0.76 & 99.24 & 94 & 71.21 & 5 & 0.76 & 21.21 & 3.79 & 71.97 & 2.27 \\
\hline Fissurina lucida & 416 & 5.18 & 4 & 0.96 & 99.04 & 251 & 60.34 & 5 & 7.21 & 59.62 & absent & 30.05 & 3.13 \\
\hline Fissurina marginata & 108 & 1.34 & 2 & 1.85 & 98.15 & 60 & 55.56 & 5 & absent & 12.04 & 4.63 & 64.81 & 18.52 \\
\hline Fissurina orbignyana & 70 & 0.87 & 0 & 0.00 & 100.00 & 45 & 64.29 & 6 & absent & 1.45 & absent & 86.96 & 11.59 \\
\hline Fissurina all spp. & 1140 & 14.19 & 12 & 1.05 & 98.95 & 868 & 76.14 & & 3.17 & 11.37 & 1.67 & 52.86 & 30.93 \\
\hline Fursenkoina apertura & 113 & 1.41 & 49 & 43.36 & 56.64 & 11 & 9.73 & 1 & absent & absent & absent & absent & 100.00 \\
\hline Fursenkoina bramletti & 30 & 0.37 & 0 & 0.00 & 100.00 & 19 & 63.33 & 6 & absent & absent & absent & absent & 100.00 \\
\hline Fursenkoina complanata & 97 & 1.21 & 0 & 0.00 & 100.00 & 53 & 54.64 & 6 & absent & 25.77 & absent & 59.79 & 14.43 \\
\hline Fursenkoina earlandi & 45 & 0.56 & 11 & 24.44 & 75.56 & 13 & 28.89 & 2 & absent & absent & absent & 4.44 & 95.56 \\
\hline Fursenkoina mexicana & 35 & 0.44 & 1 & 2.86 & 97.14 & 18 & 51.43 & 4 & absent & 22.86 & absent & 2.86 & 74.29 \\
\hline Fursenkoina pontoni & 212 & 2.64 & 103 & 48.58 & 51.42 & 32 & 15.09 & 1 & absent & 28.30 & absent & 64.62 & 7.08 \\
\hline Fursenkoina punctata & 158 & 1.97 & 18 & 11.39 & 88.61 & 39 & 24.68 & 3 & absent & 31.01 & absent & 68.99 & absent \\
\hline Fursenkoina sandiegoensis & 78 & 0.97 & 3 & 3.85 & 96.15 & 34 & 43.59 & 4 & absent & 16.67 & absent & 2.56 & 80.77 \\
\hline Fursenkoina schreibersiana & 81 & 1.01 & 2 & 2.47 & 97.53 & 31 & 38.27 & 4 & absent & 23.46 & absent & 64.20 & 12.35 \\
\hline Glandulina & 106 & 1.32 & 0 & 0.00 & 100.00 & 75 & 70.75 & 6 & absent & absent & 3.77 & 66.04 & 30.19 \\
\hline Globulina all spp. & 22 & 0.27 & 0 & 0.00 & 100.00 & 16 & 72.73 & 6 & absent & absent & 9.09 & 72.73 & 18.18 \\
\hline Globocassidulina subglobosa & 595 & 7.41 & 33 & 5.55 & 94.45 & 284 & 47.73 & 4 & absent & 4.37 & absent & 45.04 & 50.59 \\
\hline Guttulina lactea & 30 & 0.37 & 0 & 0.00 & 100.00 & 20 & 66.67 & 6 & absent & 3.33 & 3.33 & 93.33 & absent \\
\hline Guttulina problema & 53 & 0.66 & 3 & 5.66 & 94.34 & 18 & 33.96 & 4 & absent & absent & absent & 100.00 & absent \\
\hline Guttulina all spp. & 154 & 1.92 & 7 & 4.55 & 95.45 & 80 & 51.95 & 4 & absent & 4.55 & 10.39 & 81.82 & 3.25 \\
\hline
\end{tabular}


Table 2. (Continued)

Occurrences

$\%$ of samples in each major environment

Samples \% all $\begin{gathered}\text { Samples } \% \text { samples } \% \text { samples } \\ \text { abund abund }\end{gathered}$ abund abund abund abundance with sp. $\quad$ samples $\quad>10 \% \quad>10 \% \quad<10 \% \quad<1 \% \quad<1 \% \quad$ Group Marsh Marginal $\quad r$ Deep

Gyroidina altiformis

Gyroidina lamarckiana

Gyroidina neosoldanii

Gyroidina orbicularis

Gyroidina polia

Gyroidina umbonata

Gyroidina all spp.

Haynesina germanica

Haynesina orbiculare

Helenina anderseni

Hoeglundina elegans

Hopkinsina pacifica atlantica

Hyalinea balthica

Lagena clavata

Lagena gracillima

Lagena laevis

Lagena striata

Lagena substriato

Lagena all spp.

Lamarckina haliotidea

Laricarinina pauperata

Lenticulina peregrina

Lenticulina all spp.

Marginulina

Melonis barleeanum

Melonis pompilioides

Melonis all spp.

Nodosaria

Nonion depressulus

Nonionellina labradorica

Nuttallides pusillus

Nuttallides umboniferus

Oolina

Oridorsalis sidebottomi

Oridorsalis tener

Oridorsalis umbonatus

Osangularia culter

Patellina corrugata

Polymorphinid

Pullenia bulloides

Pullenia osloensis

Pullenia quinqueloba

Pullenia salisburyi

Pullenia simplex

Pullenia subcarinata

Reussella aculeata

Reussella atlantica

Reussella pacifica

Reussella spinulosa

Reussella all spp.

Robertina arctica

Robertina charlottensis

Robertina all spp.

Siphonina bradyana

Siphonina pulchra

Siphonina reticulata

Siphonina tubulosa

Siphonina all spp.

Sphaeroidina bulloides

Spirillina vivipara

Stainforthia fusiformis

Stainforthia concava

Stainforthia loeblichi

Trifarina angulosa

Trifarina fluens

Vasiglobulina

$\begin{array}{rr}76 & 0.95 \\ 90 & 1.12 \\ 50 & 0.62 \\ 121 & 1.51 \\ 83 & 1.03 \\ 167 & 2.08 \\ 739 & 9.20 \\ 185 & 14.75 \\ 134 & 1.67 \\ 148 & 1.84 \\ 290 & 3.61\end{array}$

$354 \quad 4.41 \quad 38$

$246 \quad 3.06$

$\begin{array}{ll}46 & 0.57\end{array}$

$54 \quad 0.67$

$\begin{array}{ll}49 & 0.61 \\ 64 & 0.80\end{array}$

$\begin{array}{ll}38 & 0.47\end{array}$

$825 \quad 10.27$

$\begin{array}{ll}61 & 0.76\end{array}$

$35 \quad 0.44$

$95 \quad 1.18$

$\begin{array}{ll}955 & 7.91\end{array}$

$\begin{array}{rr}43 & 0.54 \\ 553 & 6.88\end{array}$

$124 \quad 1.54$

$679 \quad 8.45$
55

$55 \quad 0.68$

$548 \quad 6.82$

$205 \quad 2.55$

$\begin{array}{rr}51 & 0.63 \\ 150 & 1.87\end{array}$

$133 \quad 1.66$

$\begin{array}{ll}7 & 0.09\end{array}$

$\begin{array}{rr}31 & 0.39 \\ 335 & 4.17\end{array}$

$48 \quad 0.60$

$215 \quad 2.68$

$124 \quad 1.54$

$\begin{array}{ll}389 & 4.84\end{array}$

$83 \quad 1.03$

$100 \quad 1.25$

$\begin{array}{ll}63 & 0.78\end{array}$

$105 \quad 1.31$

$366 \quad 3.31$

$42 \quad 0.52$

$84 \quad 1.05$

$16 \quad 0.20$

$\begin{array}{ll}223 & 2.78 \\ 376 & 4.68\end{array}$

4.68

$\begin{array}{ll}81 & 1.01 \\ 28 & 0.35\end{array}$

$\begin{array}{ll}288 & 3.59\end{array}$

$33 \quad 0.41$

$\begin{array}{ll}38 & 0.47\end{array}$

$\begin{array}{ll}16 & 0.20\end{array}$

$\begin{array}{rr}23 & 0.29 \\ 114 & 1.42\end{array}$

$114 \quad 1.42$

$133 \quad 1.66$

$\begin{array}{ll}277 & 3.45 \\ 647 & 8.06\end{array}$

$\begin{array}{ll}647 & 8.06 \\ 102 & 1.27\end{array}$

$\begin{array}{ll}102 & 1.27 \\ 70 & 0.87\end{array}$

$621 \quad 7.73$

$\begin{array}{ll}74 & 0.92\end{array}$

$40 \quad 0.50$

$\begin{array}{rcrrr}0.00 & 100.00 & 58 & 76.32 & 6 \\ 0.00 & 100.00 & 45 & 50.00 & 6 \\ 0.00 & 100.00 & 27 & 54.00 & 6 \\ 2.48 & 97.52 & 59 & 48.76 & 4 \\ 0.00 & 100.00 & 51 & 61.45 & 6 \\ 0.60 & 99.40 & 118 & 70.66 & 5 \\ 0.68 & 99.32 & 462 & 62.52 & \end{array}$

$\begin{array}{llll}0.68 & 99.32 & 462 & 62.52\end{array}$

$\begin{array}{llll}69.28 & 30.72 & 78 & 6.58\end{array}$

$\begin{array}{llll}50.75 & 49.25 & 12 & 8.96\end{array}$

$\begin{array}{llll}17.57 & 82.43 & 54 & 36.49\end{array}$

$\begin{array}{rrrr}8.62 & 91.38 & 120 & 41.38\end{array}$

$\begin{array}{llll}10.73 & 89.27 & 117 & 33.05\end{array}$

$\begin{array}{llll}4.47 & 95.53 & 125 & 50.81\end{array}$

$\begin{array}{llrl}0.00 & 100.00 & 35 & 76.09\end{array}$

$\begin{array}{llll}0.00 & 100.00 & 44 & 81.48\end{array}$

$\begin{array}{llll}0.00 & 100.00 & 38 & 77.55\end{array}$

$\begin{array}{llll}1.56 & 98.44 & 56 & 87.50\end{array}$

$\begin{array}{llll}0.00 & 100.00 & 28 & 73.68\end{array}$

$\begin{array}{llll}0.48 & 99.52 & 631 & 76.48\end{array}$

$\begin{array}{llll}0.00 & 100.00 & 33 & 54.10\end{array}$

$\begin{array}{llll}0.00 & 100.00 & 24 & 68.57\end{array}$

$\begin{array}{llll}0.00 & 100.00 & 78 & 82.11\end{array}$

$\begin{array}{llll}0.31 & 99.69 & 519 & 81.73\end{array}$

$\begin{array}{llll}0.00 & 100.00 & 42 & 97.67\end{array}$

$\begin{array}{llll}20.25 & 79.75 & 138 & 24.95\end{array}$

$\begin{array}{llll}1.61 & 98.39 & 53 & 42.74\end{array}$

$\begin{array}{llll}1.77 & 98.23 & 194 & 28.57\end{array}$

$\begin{array}{llll}0.00 & 100.00 & 48 & 87.27\end{array}$

$\begin{array}{llll}14.05 & 85.95 & 231 & 42.15\end{array}$

$\begin{array}{lrrr}34.15 & 65.85 & 32 & 15.61\end{array}$

$\begin{array}{llll}31.37 & 68.63 & 19 & 37.25\end{array}$

$\begin{array}{llll}12.00 & 88.00 & 53 & 35.33\end{array}$

$\begin{array}{llll}0.00 & 100.00 & 96 & 72.18\end{array}$

$\begin{array}{llll}0.00 & 100.00 & 3 & 42.86\end{array}$

$\begin{array}{ll}0.00 & 100.00\end{array}$

$5.07 \quad 94.93$

$\begin{array}{ll}0.00 & 100.00\end{array}$

$3.72 \quad 96.28$

$0.00 \quad 100.00$

$5.14 \quad 94.86$

26.51

73.49

$0.00 \quad 100.00$

$3.81 \quad 96.19$

\begin{tabular}{l}
$1.50 \quad 98.50$ \\
\hline
\end{tabular}

2.38

3.57

6.25

1.79

2.39

3.70

0.00

2.08

0.00

0.00

0.00

0.00
0.00

0.00
13.00

40.65

0.98

15.71

12.40

2.70

0.00

96.43

93.75

98.21

97.61

96.30

100.00

97.92
100.00

100.00

100.00

100.00

100.00

$\begin{array}{rrr}87.00 & 109 & 39.35\end{array}$

$\begin{array}{lll}59.35 & 149 & 23.03\end{array}$

$\begin{array}{lll}99.02 & 68 & 66.67\end{array}$

$\begin{array}{lrr}84.29 & 22 & 31.43\end{array}$

32.21

100.00

$\begin{array}{ll}17 & 22.97 \\ 20 & 50.00\end{array}$

absent absent absent absent $\mathbf{1 0 0 . 0 0}$

$\begin{array}{lllll}\text { absent } & \text { absent } & \text { absent } & 3.33 & \mathbf{9 6 . 6 7}\end{array}$

absent absent absent $2.00 \quad \mathbf{9 8 . 0 0}$

absent absent absent $0.83 \quad \mathbf{9 9 . 1 7}$

absent absent absent absent $\mathbf{1 0 0 . 0 0}$

$\begin{array}{lllll}\text { absent } & \text { absent } & \text { absent } & 14.97 & \mathbf{8 5 . 0 3}\end{array}$

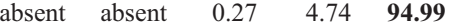

$\begin{array}{lllll}15.78 & \mathbf{8 1 . 7 7} & 1.10 & 1.35 & \text { absent }\end{array}$

$\begin{array}{llll}35.07 & \mathbf{5 0 . 7 5} & 14.18 \text { absent absent }\end{array}$

$\begin{array}{llll}\mathbf{5 1 . 3 5} & 31.76 & 16.89 & \text { absent absent }\end{array}$

absent absent absent $14.48 \quad \mathbf{8 5 . 5 2}$

absent 47.46 absent $\mathbf{5 2 . 5 4}$ absent

$\begin{array}{lllll}\text { absent } & \text { absent } & 11.79 & \mathbf{4 8 . 3 7} & 39.84\end{array}$

$\begin{array}{lllll}\text { absent } & 13.04 & \text { absent } & \mathbf{8 4 . 7 8} & 2.17\end{array}$

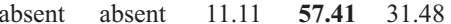

$\begin{array}{lllll}\text { absent } & 12.00 & 6.00 & \mathbf{7 8 . 0 0} & 4.00\end{array}$

absent $\quad 4.69$ absent $\quad \mathbf{8 9 . 0 6} \quad 6.25$

$\begin{array}{lllll}\text { absent } & 7.89 & 2.63 & \mathbf{8 4 . 2 1} & 5.26\end{array}$

$\begin{array}{lllll}2.91 & 4.48 & 2.18 & \mathbf{6 2 . 0 6} & 28.36\end{array}$

$\begin{array}{lllll}\text { absent } & 9.84 & 1.64 & \mathbf{8 8 . 5 2} & \text { absent }\end{array}$

absent absent absent absent $\mathbf{1 0 0 . 0 0}$

absent absent absent $18.95 \quad \mathbf{8 1 . 0 5}$

$\begin{array}{llllll}\text { absent } & 0.79 & 0.94 & 46.61 & \mathbf{5 1 . 6 5}\end{array}$

absent absent absent $48.84 \quad \mathbf{5 1 . 1 6}$

$\begin{array}{lllll}\text { absent } & \text { absent } & 2.17 & 22.97 & \mathbf{7 4 . 8 6}\end{array}$

$\begin{array}{lllll}\text { absent } & 4.03 & \text { absent } & 29.84 & \mathbf{6 6 . 1 3}\end{array}$

$\begin{array}{lllll}\text { absent } & 0.74 & 1.77 & 24.15 & \mathbf{7 3 . 3 4}\end{array}$

$\begin{array}{lllll}\text { absent } & 1.82 & 1.82 & \mathbf{5 6 . 3 6} & 40.00\end{array}$

$\begin{array}{lllll}0.91 & \mathbf{6 0 . 4 0} & 0.73 & 37.96 & \text { absent }\end{array}$

$\begin{array}{lllll}\text { absent } & \text { absent } & \mathbf{5 8 . 5 4} & 21.46 & 20.00\end{array}$

absent absent absent absent $\mathbf{1 0 0 . 0 0}$

absent absent absent absent $\mathbf{1 0 0 . 0 0}$

$\begin{array}{llllll}3.01 & 3.76 & 1.50 & 36.84 & \mathbf{5 4 . 8 9}\end{array}$

absent absent absent absent $\mathbf{1 0 0 . 0 0}$

absent absent absent absent $\mathbf{1 0 0 . 0 0}$

$\begin{array}{lllll}\text { absent } & \text { absent } & 1.19 & 2.09 & \mathbf{9 6 . 7 2}\end{array}$

absent absent absent absent $\mathbf{1 0 0 . 0 0}$

$\begin{array}{lllll}\text { absent } & 4.15 & 3.69 & \mathbf{8 0 . 1 8} & 11.98\end{array}$

$\begin{array}{lllll}\text { absent } & \text { absent } & 14.71 & \mathbf{7 3 . 5 3} & 11.76\end{array}$

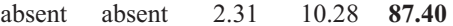

$\begin{array}{lllll}\text { absent } & \text { absent } & 20.48 & \mathbf{6 5 . 0 6} & 14.46\end{array}$

absent absent absent $7.00 \quad \mathbf{9 3 . 0 0}$

absent absent absent absent $\mathbf{1 0 0 . 0 0}$

absent absent absent absent $\mathbf{1 0 0 . 0 0}$

$\begin{array}{llll}\text { absent absent } & 2.26 & 15.79 & \mathbf{8 1 . 9 5}\end{array}$

$\begin{array}{lllll}\text { absent } & 2.33 & \text { absent } & \mathbf{9 7 . 6 7} & \text { absent }\end{array}$

absent 39.29 absent $\mathbf{6 0 . 7 1}$ absent

absent 6.25 absent $\mathbf{9 3 . 7 5}$ absent

absent absent absent $\mathbf{1 0 0 . 0 0}$ absent

absent 9.31 absent $\mathbf{9 0 . 6 9}$ absent

$\begin{array}{lllll}\text { absent } & 1.23 & 19.75 & \mathbf{6 6 . 6 7} & 12.35\end{array}$

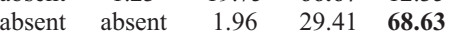

$\begin{array}{lllll}\text { absent } & 0.35 & 6.60 & 30.90 & \mathbf{6 2 . 1 5}\end{array}$

$\begin{array}{llll}\text { absent absent absent } & 18.18 & \mathbf{8 1 . 8 2}\end{array}$

$\begin{array}{lllll}\text { absent } & \mathbf{5 5 . 2 6} & \text { absent } & 42.11 & 2.63\end{array}$

absent absent absent $\mathbf{6 2 . 5 0} \quad 37.50$

$\begin{array}{lllll}\text { absent } & 4.35 & \text { absent } & \mathbf{9 1 . 3 0} & 4.35\end{array}$

$\begin{array}{lllll}\text { absent } & 19.30 & \text { absent } & \mathbf{5 0 . 0 0} & 30.70\end{array}$

absent absent absent $23.31 \quad \mathbf{7 6 . 6 9}$

$\begin{array}{lllll}9.72 & 12.11 & \text { absent } & \mathbf{7 6 . 4 7} & 1.74\end{array}$

absent $\quad 23.96 \quad 17.31 \quad \mathbf{5 4 . 1 0} \quad 4.64$

$\begin{array}{lllll}\text { absent } & 0.98 & 17.65 & \mathbf{6 4 . 7 1} & 16.67\end{array}$

$\begin{array}{llll}\text { absent absent } & \mathbf{6 4 . 2 9} & 30.00 & 5.71\end{array}$

$\begin{array}{lllll}\text { absent } & 3.22 & 1.77 & \mathbf{6 8 . 2 8} & 26.73\end{array}$

absent absent $20.27 \quad 35.14 \quad \mathbf{4 4 . 5 9}$

absent absent absent $\mathbf{1 0 0 . 0 0}$ absent

Column 2 gives the number of samples containing a named species and column 3 its proportion of the whole dataset. Column 4 gives the number of samples where the species abundance is $>10 \%$. Columns 5 and 6 give the proportion of samples where the abundance of a species is $>10 \%$ or $10 \%$ respectively. Column 7 gives the number of samples where the species abundance is $<1 \%$ and Column 8 the proportion of samples with this abundance. Column 9 gives the abundance group defined in Table 1 . Columns

10-14 give the proportion of samples of the named species in each major enviornment; the maximum values are highlighted in bold. 
Table 3. Mean and maximum abundance values for each taxon in each major environment.

\begin{tabular}{|c|c|c|c|c|c|c|c|c|c|c|c|}
\hline \multirow[b]{2}{*}{ Species } & \multirow[b]{2}{*}{$\begin{array}{c}\text { Overall } \\
\text { mean } \%\end{array}$} & \multicolumn{5}{|c|}{ Environments - abundance mean \% } & \multicolumn{5}{|c|}{ Environments - abundance maximum \% } \\
\hline & & Marsh & Marg. mar. & Fjord & Shelf & Deep sea & Marsh & Marg. mar. & Fjord & Shelf & Deep sea \\
\hline \multicolumn{12}{|l|}{ Agglutinated } \\
\hline Ammoastuta inepta & 11.33 & 17.12 & 3.95 & absent & 1.00 & absent & 51.50 & 12.00 & absent & 1.00 & absent \\
\hline Ammobaculites agglutinans & 2.51 & absent & 0.89 & 5.00 & 1.65 & 2.94 & absent & 2.20 & 6.00 & 15.40 & 25.60 \\
\hline Ammobaculites balkwilli & 3.75 & 6.95 & 3.73 & 3.00 & absent & absent & 13.60 & 44.00 & 7.50 & absent & absent \\
\hline Ammobaculites dilatatus & 3.76 & 6.09 & 2.67 & absent & 1.14 & absent & 93.00 & 34.00 & absent & 3.20 & absent \\
\hline Ammobaculites exiguus & 5.76 & 7.61 & 1.26 & absent & 1.85 & absent & 90.00 & 2.00 & absent & 13.80 & absent \\
\hline Ammobaculites filiformis & 1.66 & absent & absent & absent & 0.20 & 1.68 & absent & absent & absent & 0.20 & 14.90 \\
\hline Ammoscalaria runiana & 3.06 & 1.19 & 3.40 & 1.75 & 0.77 & absent & 1.60 & 34.65 & 3.80 & 1.50 & absent \\
\hline Ammotium salsum & 16.39 & 17.17 & 17.22 & absent & 7.07 & absent & 100.00 & 100.00 & absent & 38.00 & absent \\
\hline Arenoparella mexicana & 9.13 & 10.12 & 3.86 & absent & absent & absent & 92.00 & 28.10 & absent & absent & absent \\
\hline Balticammina pseudomacrescens & 39.69 & absent & absent & absent & absent & absent & 39.69 & absent & absent & absent & absent \\
\hline Eggerella advena & 7.90 & 1.13 & 26.68 & 2.20 & 7.68 & 2.29 & 2.00 & 78.80 & 6.40 & 68.40 & 30.80 \\
\hline Eggerella europea & 0.50 & absent & absent & 0.37 & 0.53 & absent & absent & absent & 0.40 & 4.80 & absent \\
\hline Eggerelloides medius & 7.02 & absent & absent & 14.19 & 4.80 & 0.10 & absent & absent & 49.40 & 24.90 & 0.10 \\
\hline Eggerelloides scaber & 6.39 & absent & 4.16 & 16.17 & 4.87 & 1.92 & absent & 67.60 & 83.20 & 47.60 & 10.51 \\
\hline Gaudryina exilis & 2.41 & 5.74 & 1.79 & absent & 0.51 & absent & 27.50 & 5.70 & absent & 1.30 & absent \\
\hline Gaudryina pauperata & 2.41 & 2.12 & 3.76 & absent & 1.93 & 1.00 & 8.00 & 14.00 & absent & 3.00 & 1.00 \\
\hline Glomospira gordialis & 1.11 & 2.20 & 1.49 & 2.67 & 1.32 & 0.76 & 2.20 & 17.02 & 2.67 & 7.02 & 3.20 \\
\hline Haplophragmoides bradyi & 2.29 & absent & absent & 7.23 & 2.16 & 1.67 & absent & absent & 15.38 & 13.64 & 26.15 \\
\hline Haplophragmoides shallow spp. & 11.71 & 12.51 & 1.47 & absent & 1.00 & absent & 96.05 & 9.60 & absent & 1.00 & absent \\
\hline Jadammina macrescens & 16.84 & 19.84 & 3.73 & 0.50 & 2.95 & absent & 100.00 & 76.30 & 0.50 & 4.60 & absent \\
\hline Miliammina fusca & 19.66 & 26.75 & 10.42 & 9.83 & 7.64 & absent & 100.00 & 100.00 & 88.00 & 44.90 & absent \\
\hline Reophax moniliformis & 3.20 & 3.75 & 3.41 & 3.80 & 1.22 & absent & 34.20 & 19.60 & 3.80 & 10.90 & absent \\
\hline Reophax nana & 3.92 & 4.14 & 4.11 & absent & 2.00 & absent & 17.00 & 48.00 & absent & 7.70 & absent \\
\hline Siphotrochammina lobata & 7.63 & 8.62 & 3.08 & absent & absent & absent & 33.00 & 8.30 & absent & absent & absent \\
\hline Textularia earlandi & 2.64 & 2.69 & 2.79 & 2.05 & 2.85 & 2.16 & 17.10 & 58.50 & 26.80 & 30.30 & 25.50 \\
\hline Tiphotrocha comprimata & 14.74 & 14.96 & 2.17 & absent & absent & absent & 80.00 & 2.30 & absent & absent & absent \\
\hline Trochammina inflata & 17.37 & 19.84 & 3.73 & 0.50 & 2.95 & absent & 100.00 & 76.30 & 0.50 & 4.60 & absent \\
\hline Trochammina lobata & 2.71 & absent & absent & absent & 2.82 & 0.65 & absent & absent & absent & 27.50 & 1.30 \\
\hline Trochammina pacifica & 3.27 & absent & 2.10 & absent & 5.33 & 1.53 & absent & 34.97 & absent & 38.33 & 16.00 \\
\hline Uszbekistania charoides & 1.06 & absent & 1.10 & absent & 0.84 & 1.15 & absent & 1.00 & absent & 5.74 & 4.62 \\
\hline \multicolumn{12}{|l|}{ Porcelaneous } \\
\hline Cornuspira involvens & 2.19 & 3.03 & 2.07 & 4.41 & 1.85 & 1.27 & 53.00 & 37.30 & 48.40 & 47.00 & 35.00 \\
\hline Pyrgo williamsoni & 1.67 & absent & 0.47 & 1.27 & 1.83 & 0.91 & absent & 0.47 & 5.94 & 19.17 & 3.00 \\
\hline \multicolumn{12}{|l|}{ Hyaline } \\
\hline Amphicoryna & 1.37 & absent & absent & absent & 1.46 & 1.29 & absent & absent & absent & 15.40 & 11.30 \\
\hline Astacolus & 0.67 & absent & absent & 1.54 & 0.55 & 0.79 & absent & absent & 4.21 & 1.90 & 2.40 \\
\hline Asterigerina carinata & 5.33 & absent & 2.77 & absent & 9.41 & absent & absent & 5.20 & absent & 27.64 & absent \\
\hline Asterigerinata adriatica & 4.54 & absent & absent & absent & 4.54 & absent & absent & absent & absent & 14.00 & absent \\
\hline Asterigerinata mamilla & 1.52 & absent & 2.00 & absent & 1.45 & 0.50 & absent & 5.20 & absent & 27.64 & 0.50 \\
\hline Astrononion echolsi & 2.29 & absent & absent & absent & absent & 2.29 & absent & absent & absent & absent & 8.02 \\
\hline Astrononion gallowayi & 4.38 & absent & absent & 4.87 & 5.43 & 2.12 & absent & absent & 34.97 & 38.33 & 16.00 \\
\hline Astrononion sidebottomi & 1.19 & absent & absent & absent & 1.19 & absent & absent & absent & absent & 11.00 & absent \\
\hline Astrononion stelligerum & 1.27 & absent & 1.40 & absent & 1.43 & 0.57 & absent & 1.40 & absent & 6.50 & 2.00 \\
\hline Astrononion all spp. & 2.74 & absent & 1.57 & 4.96 & 2.91 & 1.78 & absent & 4.00 & 34.97 & 38.33 & 16.00 \\
\hline Buliminella elegantissima & 4.75 & 4.42 & 4.91 & 0.10 & 4.60 & 2.93 & 21.00 & 77.23 & 0.10 & 97.00 & 17.00 \\
\hline Dentalina spp. & 0.76 & absent & 0.60 & 0.24 & 0.89 & 0.72 & absent & 0.60 & 1.40 & 7.70 & 4.80 \\
\hline Ehrenbergina & 3.02 & absent & 0.51 & absent & 2.29 & 3.44 & absent & 0.51 & absent & 22.00 & 18.96 \\
\hline Fissurina laevigata & 0.87 & 0.70 & 1.75 & 0.98 & 0.61 & 0.63 & 0.70 & 10.00 & 2.22 & 2.90 & 0.60 \\
\hline Fissurina lucida & 1.34 & 3.29 & 1.39 & absent & 0.79 & 1.12 & 10.30 & 10.00 & absent & 3.60 & 3.00 \\
\hline Fissurina marginata & 1.31 & absent & 0.83 & 0.57 & 1.36 & 1.65 & absent & 2.35 & 2.22 & 10.53 & 12.50 \\
\hline Fissurina orbignyana & 0.98 & absent & 1.80 & absent & 0.91 & 0.84 & absent & 1.80 & absent & 3.20 & 0.90 \\
\hline Fissurina all spp. & 1.09 & 2.86 & 1.41 & 1.13 & 0.94 & 1.06 & 10.30 & 10.00 & 2.22 & 24.20 & 12.66 \\
\hline Fursenkoina apertura & 12.60 & absent & absent & absent & absent & 12.60 & absent & absent & absent & absent & 62.00 \\
\hline Fursenkoina bramletti & 1.54 & absent & absent & absent & absent & 1.54 & absent & absent & absent & absent & 6.20 \\
\hline Fursenkoina complanata & 1.29 & absent & 1.75 & absent & 1.07 & 1.36 & absent & 8.00 & absent & 5.10 & 8.90 \\
\hline Fursenkoina earlandi & 8.62 & absent & absent & absent & 1.00 & 8.98 & absent & absent & absent & 22.00 & 67.00 \\
\hline Fursenkoina mexicana & 2.68 & absent & 0.64 & absent & 0.80 & 3.38 & absent & 1.20 & absent & 0.80 & 23.10 \\
\hline Fursenkoina pontoni & 16.65 & absent & 13.61 & absent & 18.62 & 10.80 & absent & 74.70 & absent & 90.10 & 25.80 \\
\hline Fursenkoina punctata & 4.90 & absent & 8.78 & absent & 3.16 & absent & absent & 56.40 & absent & 22.20 & absent \\
\hline Fursenkoina sandiegoensis & 2.31 & absent & 4.31 & absent & 0.40 & 1.96 & absent & 13.00 & absent & 0.60 & 12.00 \\
\hline Fursenkoina schreibersiana & 2.51 & absent & 2.66 & absent & 2.70 & 1.19 & absent & 9.60 & absent & 38.60 & 3.00 \\
\hline Glandulina & 0.83 & absent & absent & 0.66 & 0.94 & 0.63 & absent & absent & 2.00 & 6.90 & 2.00 \\
\hline Globulina all spp. & 1.01 & absent & absent & 0.41 & 1.17 & 0.67 & absent & absent & 0.50 & 1.31 & 0.68 \\
\hline Globocassidulina subglobosa & 2.54 & absent & 3.62 & absent & 2.37 & 2.61 & absent & 18.18 & absent & 27.00 & 28.80 \\
\hline Guttulina lactea & 0.82 & absent & 0.20 & 1.20 & 0.83 & absent & absent & 0.20 & 1.20 & 2.92 & absent \\
\hline Guttulina problema & 3.47 & absent & absent & absent & 3.47 & absent & absent & absent & absent & 15.22 & absent \\
\hline Guttulina all spp. & 2.30 & absent & 11.12 & 0.45 & 2.12 & 0.42 & absent & 45.44 & 1.20 & 15.22 & 1.30 \\
\hline
\end{tabular}


Environments - abundance mean \%

Environments - abundance maximum \%

\begin{tabular}{|c|c|c|c|c|c|c|c|c|c|c|c|}
\hline Species & $\begin{array}{l}\text { Overall } \\
\text { mean \% }\end{array}$ & Marsh & Marg. mar. & Fjord & Shelf & Deep sea & Marsh & Marg. mar. & Fjord & Shelf & Deep sea \\
\hline Gyroidina altiformis & 0.91 & absent & absent & absent & absent & 0.91 & absent & absent & absent & absent & 9.79 \\
\hline Gyroidina lamarckiana & 1.62 & absent & absent & absent & 0.70 & 1.65 & absent & absent & absent & 0.90 & 9.00 \\
\hline Gyroidina orbicularis & 1.91 & absent & absent & absent & 0.06 & 1.92 & absent & absent & absent & 0.06 & 24.70 \\
\hline Gyroidina polia & 1.16 & absent & absent & absent & absent & 1.16 & absent & absent & absent & absent & 5.77 \\
\hline Gyroidina umbonata & 1.02 & absent & absent & absent & 1.30 & 0.97 & absent & absent & absent & 8.20 & 11.80 \\
\hline Gyroidina all spp. & 1.31 & absent & absent & 0.55 & 1.64 & 1.29 & absent & absent & 0.80 & 11.80 & 24.70 \\
\hline Helenina anderseni & 6.62 & 12.11 & 0.77 & 0.92 & absent & absent & 78.00 & 3.00 & 5.00 & absent & absent \\
\hline Hoeglundina elegans & 3.59 & absent & absent & absent & 5.68 & 3.23 & absent & absent & absent & 30.30 & 46.39 \\
\hline Hopkinsina pacifica atlantica & 4.75 & absent & 6.99 & absent & 2.72 & absent & absent & 56.36 & absent & 24.42 & absent \\
\hline Hyalinea balthica & 2.60 & absent & absent & 3.43 & 2.47 & 2.51 & absent & absent & 11.30 & 29.79 & 72.73 \\
\hline Lagena clavata & 0.66 & absent & 0.96 & absent & 0.62 & 0.40 & absent & 1.32 & absent & 2.09 & 0.40 \\
\hline Lagena gracillima & 0.70 & absent & absent & 1.23 & 0.67 & 0.58 & absent & absent & 3.51 & 4.10 & 2.37 \\
\hline Lagena laevis & 0.74 & absent & 1.05 & 0.57 & 0.69 & 1.01 & absent & 1.92 & 1.10 & 2.41 & 1.14 \\
\hline Laricarinina pauperata & 0.80 & absent & absent & absent & absent & 0.80 & absent & absent & absent & absent & 4.02 \\
\hline Lenticulina peregrina & 0.73 & absent & absent & absent & 0.56 & 0.77 & absent & absent & absent & 2.02 & 3.60 \\
\hline Lenticulina all spp. & 0.33 & absent & 0.84 & 0.62 & 0.41 & 0.64 & absent & 1.30 & 1.40 & 10.53 & 11.69 \\
\hline Marginulina & 0.40 & absent & absent & absent & 0.44 & 0.37 & absent & absent & absent & 0.88 & 1.32 \\
\hline Melonis barleeanum & 7.89 & absent & absent & 6.42 & 7.49 & 8.06 & absent & absent & 16.34 & 60.22 & 86.40 \\
\hline Melonis pompilioides & 2.04 & absent & 0.73 & absent & 3.11 & 1.63 & absent & 1.07 & absent & 11.61 & 8.99 \\
\hline Melonis all spp. & 6.80 & absent & 0.73 & 6.42 & 6.50 & 6.97 & absent & 1.10 & 16.34 & 60.22 & 86.40 \\
\hline Nodosaria & 0.58 & absent & 0.16 & 0.28 & 0.54 & 0.68 & absent & 0.16 & 0.28 & 1.52 & 2.00 \\
\hline Nonion depressulus & 7.19 & 3.84 & 9.97 & 3.40 & 2.90 & absent & 5.32 & 66.50 & 9.60 & 32.40 & absent \\
\hline Nonionellina labradorica & 11.80 & absent & absent & 11.84 & 9.63 & 14.00 & absent & absent & 58.54 & 17.56 & 23.90 \\
\hline Nuttallides pusillus & 7.88 & absent & absent & absent & absent & 7.88 & absent & absent & absent & absent & 39.71 \\
\hline Nuttallides umboniferus & 4.17 & absent & absent & absent & absent & 4.17 & absent & absent & absent & absent & 33.66 \\
\hline Oolina & 0.86 & 1.50 & 1.11 & 1.00 & 1.13 & 0.62 & 2.00 & 2.84 & 1.50 & 5.88 & 5.62 \\
\hline Oridorsalis sidebottomi & 1.00 & absent & absent & absent & absent & 1.00 & absent & absent & absent & absent & 5.80 \\
\hline Pullenia simplex & 2.48 & absent & absent & absent & absent & 2.48 & absent & absent & absent & absent & 25.00 \\
\hline Pullenia subcarinata & 1.61 & absent & absent & 4.30 & 0.86 & 1.68 & absent & absent & 13.74 & 4.88 & 41.40 \\
\hline Reussella aculeata & 2.24 & absent & 0.40 & absent & 2.29 & absent & absent & 0.40 & absent & 11.23 & absent \\
\hline Reussella atlantica & 2.25 & absent & 2.72 & absent & 1.94 & absent & absent & 10.34 & absent & 10.00 & absent \\
\hline Reussella pacifica & 2.15 & absent & 0.40 & absent & 2.27 & absent & absent & 0.40 & absent & 13.00 & absent \\
\hline Reussella spinulosa & 1.71 & absent & absent & absent & 1.71 & absent & absent & absent & absent & 23.18 & absent \\
\hline Reussella all spp. & 1.88 & absent & 2.59 & absent & 1.80 & absent & absent & 11.23 & absent & 23.18 & absent \\
\hline Robertina arctica & 2.17 & absent & 0.79 & 4.12 & 1.63 & 2.14 & absent & 0.79 & 24.52 & 11.83 & 5.00 \\
\hline Robertina charlottensis & 1.91 & absent & absent & 2.44 & 1.84 & 1.93 & absent & absent & 2.44 & 4.00 & 29.30 \\
\hline Robertina all spp. & 1.55 & absent & 0.79 & 3.81 & 1.46 & 1.35 & absent & 0.79 & 24.52 & 11.83 & 29.73 \\
\hline Siphonina bradyana & 1.12 & absent & absent & absent & 1.29 & 1.08 & absent & absent & absent & 5.43 & 7.09 \\
\hline Siphonina pulchra & 2.02 & absent & 2.38 & absent & 1.62 & 1.00 & absent & 9.80 & absent & 4.40 & 0.68 \\
\hline Siphonina reticulata & 0.88 & absent & absent & absent & 1.24 & 3.02 & absent & absent & absent & 4.50 & 6.67 \\
\hline Siphonina tubulosa & 1.64 & absent & 3.22 & absent & 0.94 & 0.14 & absent & 3.22 & absent & 2.00 & 0.14 \\
\hline Siphonina all spp. & 1.63 & absent & 2.42 & absent & 1.24 & 1.38 & absent & 9.80 & absent & 5.43 & 7.09 \\
\hline Sphaeroidina bulloides & 1.17 & absent & absent & absent & 1.53 & 1.06 & absent & absent & absent & 5.30 & 9.92 \\
\hline Spirillina vivipara & 4.11 & 6.86 & 1.40 & absent & 4.25 & 0.90 & 89.00 & 5.40 & absent & $\mathbf{5 0 . 0 0}$ & 1.50 \\
\hline Stainforthia fusiformis & 18.83 & absent & 2.25 & 40.57 & 20.72 & 1.26 & absent & 32.00 & 98.41 & 93.10 & 12.40 \\
\hline Stainforthia concava & 1.20 & absent & 3.17 & 1.24 & 1.26 & 0.77 & absent & 3.17 & 5.90 & 19.20 & 2.80 \\
\hline Stainforthia loeblichi & 5.05 & absent & absent & 4.14 & 6.72 & 6.53 & absent & absent & 14.90 & 32.90 & 20.90 \\
\hline Trifarina angulosa & 5.22 & absent & 1.55 & 1.65 & 2.78 & 12.15 & absent & 4.71 & 5.52 & 41.30 & 76.00 \\
\hline Trifarina fluens & 2.95 & absent & absent & 1.54 & 2.53 & 3.92 & absent & absent & 34.97 & 38.33 & 16.00 \\
\hline Vasiglobulina & 1.49 & absent & absent & absent & 1.49 & absent & absent & absent & absent & 6.77 & absent \\
\hline
\end{tabular}

Values $>10 \%$ are highlighted. 
Table 4. Categories of species abundance.

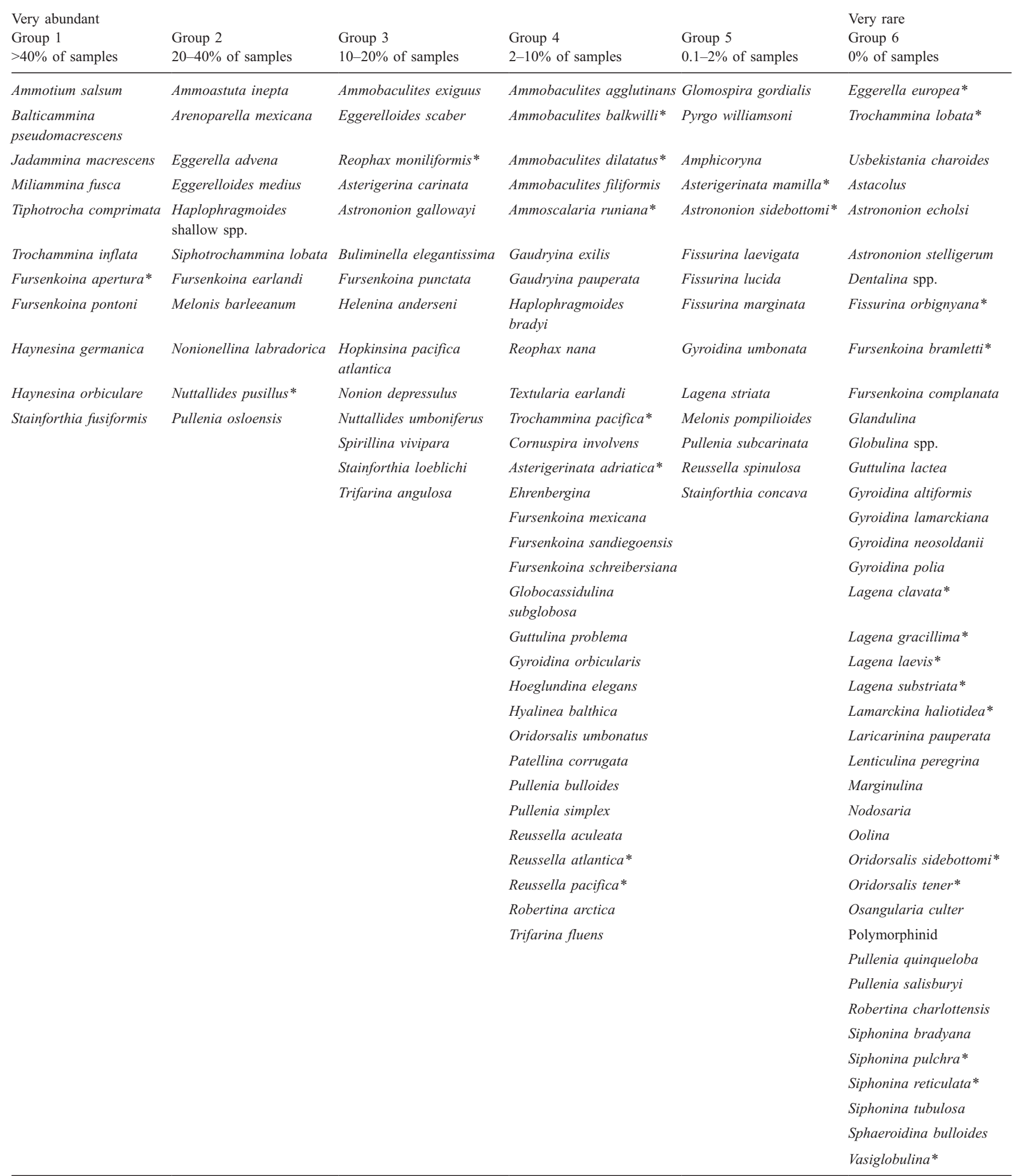

Species sorted on $\%$ of occurrences with $>10 \%$ abundance.

*Morphospecies showing a narrow distribution 
Living benthic foraminifera
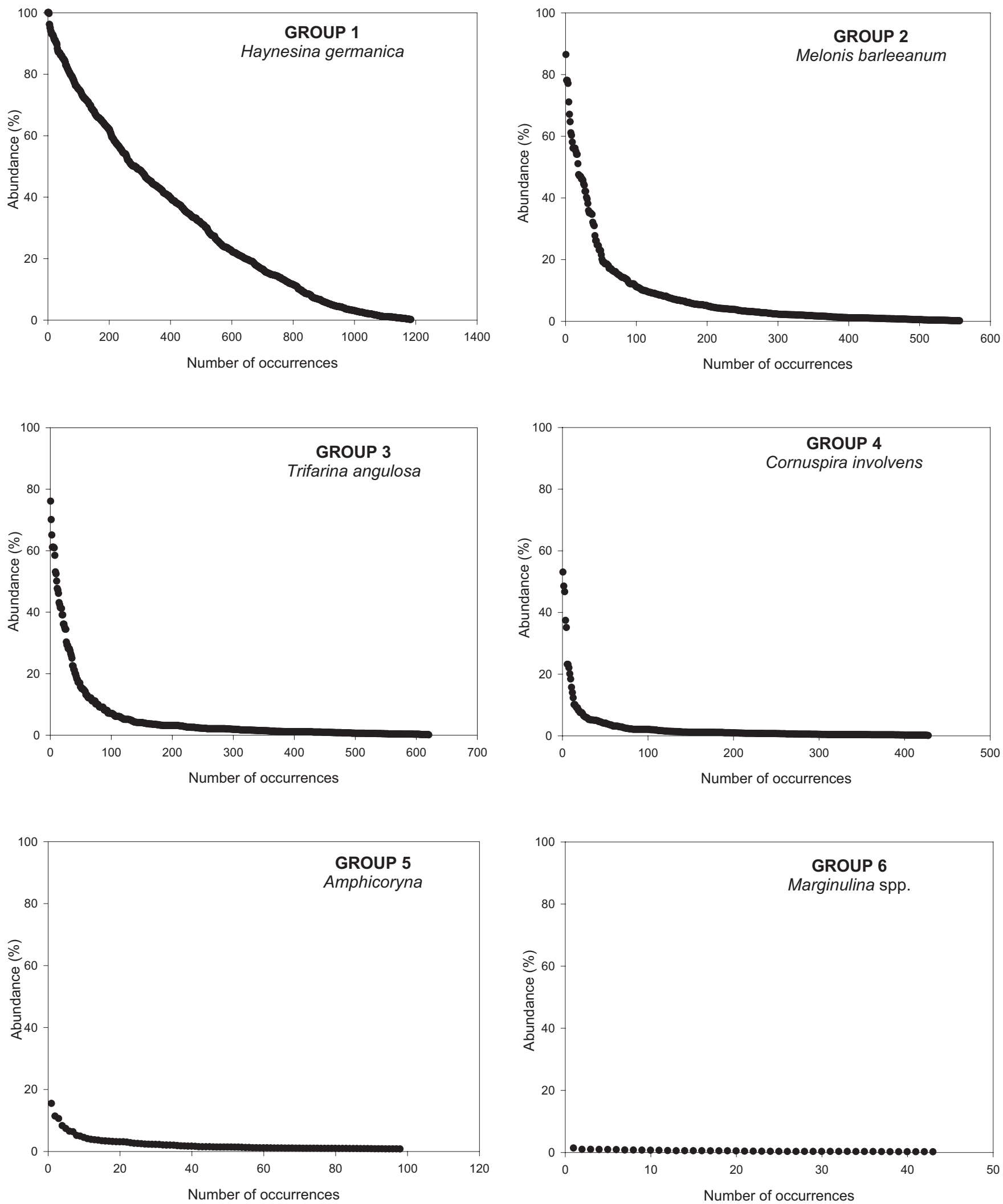

Fig. 3. Examples of abundance/occurrences plots for the six groups shown in Table 4 . 
Table 5. Distribution of morphospecies in the oceans.

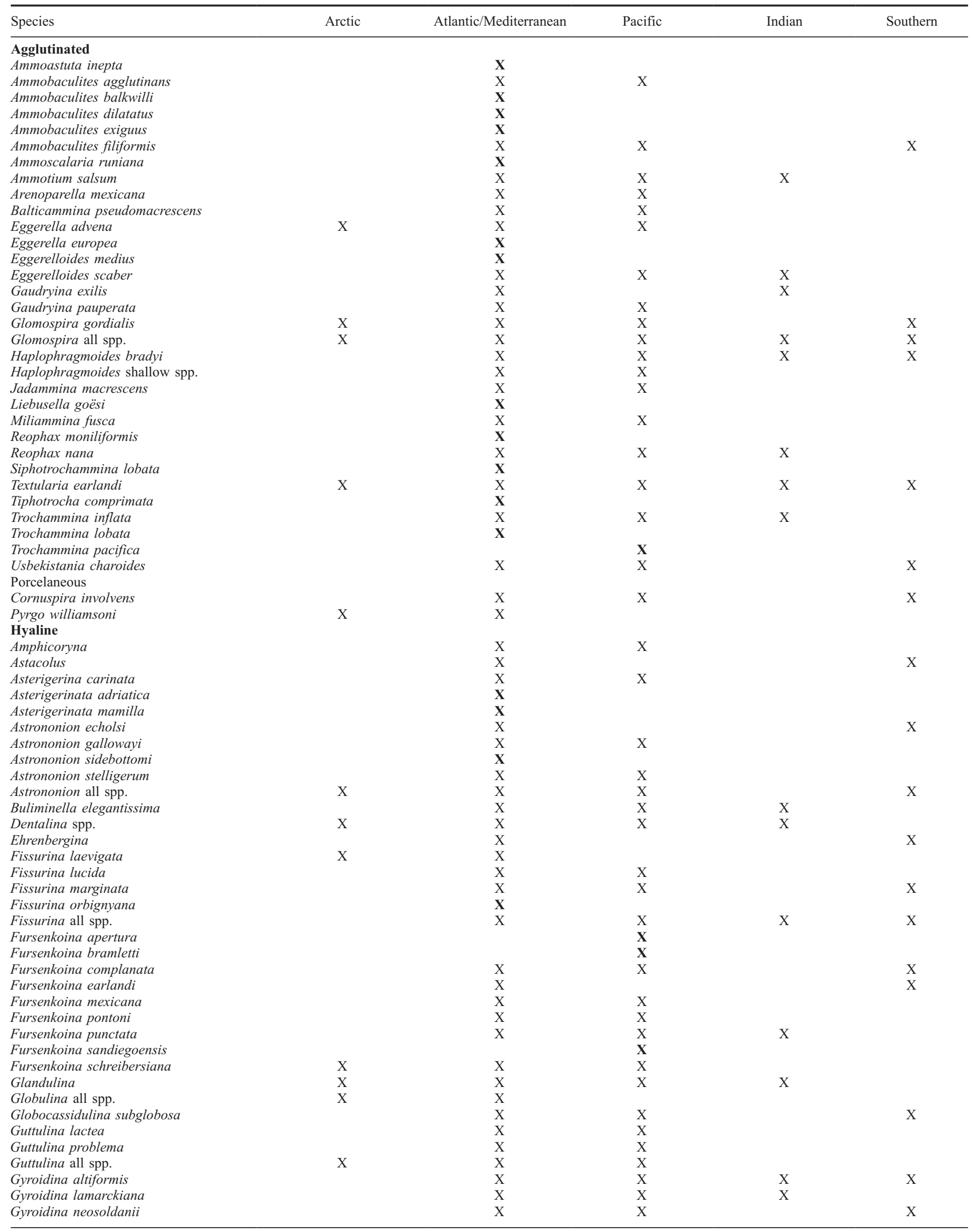


Living benthic foraminifera

Table 5. (Continued)

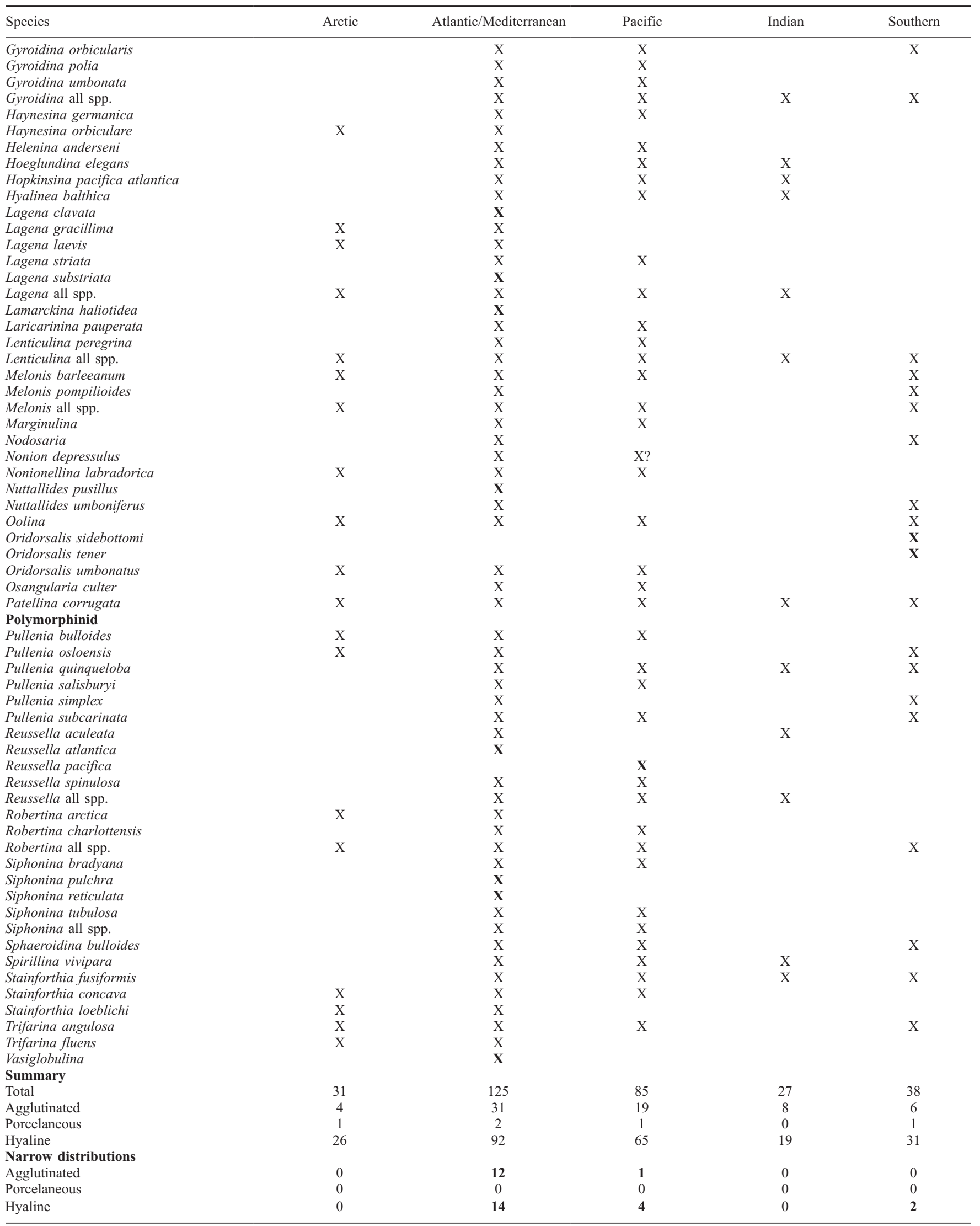

Those confined to one ocean are marked with $\mathbf{x}$ in bold. 
runiana, Eggerelloides scaber, Patellina corrugata, Spirillina vivipara) and some span all five (Eggerella advena, Glomospira gordialis, Textularia earlandi, Fissurina laevigata). In some cases misidentification of species may be responsible. For instance, before Ammobaculites balkwilli was described some authors identified it as A. agglutinans. Juvenile Liebusella goesi are easily misidentified as Eggerelloides scaber (Alve \& Goldstein, 2010) and the latter species has not always been separated from $E$. medius. Very few of the taxa analysed are restricted to a single major environment: Balticammina pseudomacrescens high marsh and Vasiglobulina shelf. All the others are from the deep sea: Astrononion echolsi, Fursenkoina apertura, F. bramletti, Gyroidina altiformis, G. polia, Laticarinina pauperata, Nuttallides pusillus, N. umboniferus, Oridorsalis sidebottomi, O. tener, Pullenia salisburyi, P. simplex.

\section{Biogeographical distributions}

Most biogeographical analyses aim to determine patterns of distribution of faunas based on evolutionary (e.g. cladistics, molecular genetics), geological (e.g. plate tectonics) or ecological criteria. This paper is not concerned with either evolutionary or geological aspects but it is noted that the majority of the types are from the Recent although some come from the Tertiary and one from the Cretaceous (Supplementary Publication table 1). Nor is it concerned with the recognition of faunal provinces because only a selection of species has been studied rather than complete faunas. This study deals with individual morphospecies, with the main emphasis on those that are relatively rare.

Ideally global coverage of data is a prerequisite for studying biogeography but this target is rarely met. The data for benthic foraminifera are not yet global in coverage and they are not a snapshot at one time as they represent 60 years of observation. The North Atlantic has the best record of living/stained distributions; therefore, the absence of a species from any part may be real rather than the limitation of sampling. Patterns can be established within the limitations of present knowledge. Some distributions are geographically more or less continuous but others are discontinuous (disjunct). Two extreme disjunct distributions are those of Pullenia osloensis (Fig. 82) ) and P. simplex which are essentially bipolar: the former in the Arctic Ocean, high latitude North Atlantic and Southern Ocean; the latter in the mid-latitude North Atlantic and South Atlantic-Southern Ocean. Such distribution patterns have implications for taxonomy. Are these disjunct species genetically the same? In other cases a single occurrence remote from the main area of occurrence may be a consequence of misidentification (e.g. Gaudryina pauperata in the Scotia Sea; Usbekistania charoides in a Gulf of Mexico lagoon; Nonion depressulus in an Australian mangal). From molecular genetic evidence of similarity in the disjunct occurrence of shallow-water phylotypes, such as Ammonia T6, it has been suggested that this is through transport of water as ballast in ships (Pawlowski \& Holzmann, 2008; Schweizer et al., 2011).

In Table 5 the Mediterranean and Gulf of Mexico-Caribbean Sea are treated as parts of the broader Atlantic Ocean. Most of the selected taxa are moderately widely distributed (94) rather than restricted to a part of one ocean (30); a higher proportion of agglutinated than hyaline forms are narrowly distributed.

\section{Narrowly distributed species}

Narrow distributions are of ecological interest. There are several reasons why a species may have a very restricted distribution: (a) it may have recently evolved and not yet developed its full range (Asterigerinata adriatica?); (b) its ecological requirements may be such that its range is limited (Eggerella europea, Eggerelloides medius); (c) it is newly described and, therefore, other occurrences have yet to be recorded (no examples have been studied here); (d) it may be unable to cross a barrier to distribution (see example below).

Thirty-three morphospecies show narrow distributions (Table 5). Among the agglutinated forms most are predominantly marsh-marginal marine inhabitants but Eggerella europea, Eggerelloides medius and Trochammina lobata are predominantly shelf inhabitants, whereas T. pacifica is a shelf-deep-sea form. Among the hyaline taxa a predominantly marginal marine inhabitant is Nonion depressulus; marginal marine-shelf Fursenkoina sandiegoensis, Siphonina pulchra; shelf Asterigerinata adriatica, A. mamilla, Astrononion sidebottomi, Fissurina orbignyana, Lagena clavata, L. gracillima, L. laevis, L. substriata, Reussella atlantica, R. pacifica, Siphonina reticulata and Vasiglobulina; deep sea Fursenkoina apertura, F. bramletti, Lamarckina haliotidea, Nuttallides pusillus, Oridorsalis sidebottomi and O. tener.

There is no correlation between species abundance and narrow distribution as there are examples in all groups (Table 4). This shows that being narrowly distributed is not an ecological disadvantage. The converse must be that being widely distributed does not always lead to high abundance.

In the North Atlantic narrowly distributed Ammobaculites dilatatus and $A$. exiguus are confined to mainly marsh-marginal marine environments along the US margin (Figs 6, 7) and absent from similar environments along the European seaboard. Similarly, Ammobaculites balkwilli (Fig. 5), Ammoscalaria runiana (Fig. 9), and Reophax moniliformis (Fig. 24), are confined to the European seaboard. Ellison \& Murray (1987) suggested that a possible explanation for Ammobaculites and Ammotium is that brackish conditions are more continuous along the coastal areas of North America, thus facilitating dispersal, whereas off Europe brackish conditions are confined to discontinuous settings, such as estuaries and lagoons. It was also postulated that the species might be evolving in North America and may have been introduced only recently into European waters. However, the presence of species restricted to either the east or the west side of the ocean may require a different explanation.

In 1936 Myers suggested that the distribution of benthic foraminifera in shallow waters depends on 'a brief pelagic phase assumed by juvenile or adult individuals' (Myers, 1936, p. 143). These are now termed propagules (tiny juveniles) and their existence has been proven by experiments (see Alve \& Goldstein, 2010 and references therein). This mechanism must be a common way of extending the range of species into suitable habitats and possibly across oceans. It readily explains the disjunct distributions of marsh and marginal marine faunas. It may be a more widespread mechanism than transport of sediment/foraminifera on the feet of birds from one area to another. But do all species have propagules? Are these agglutinated narrowly distributed species examples of taxa that do not produce propagules?

\section{Widely distributed species}

It might be expected that widely distributed morphospecies would be abundant over at least part of their range and that they would also be common. Although this is true of many of the species, it 
is not universally so. From Table 4 it can be seen that Groups 5 and 6 have few or no samples with $>10 \%$ abundance for the named species. Furthermore, most of the species in Group 6 are present in $<1 \%$ of all the samples analysed. The exceptions are Fursenkoina complanata, Gyroidina lamarckiana, G. polia, Lenticulina peregrina, Pullenia quinqueloba, Sphaeroidina bulloides and Usbekistania charoides present in $<2 \%$ of all the samples and Dentalina (2.8\%). For Group 5, most species occur in $<3 \%$ of the samples with the exception of Fissurina lucida $(5.2 \%)$ and Pullenia subcarinata $(3.3 \%)$.

Species that are widespread in occurrence but low in abundance are generally considered to be ecologically vulnerable (Hubbell, 2001). The nodosariids (Nodosariida of Haynes, 1981; Nodosariacea of Loeblich \& Tappan, 1987) evolved in the Permian, reached their culmination in the Jurassic and since then have declined in importance. Haynes pointed out that prior to the Cretaceous nodosariids occupied shallower-water environments whereas modern examples are generally from deeper water and are therefore not good analogues for interpreting Mesozoic environments. Modern representatives discussed here include Astacolus, Amphicoryna, Dentalina, Fissurina, Glandulina, Globulina, Guttulina, Lagena, Lenticulina, Marginulina, Nodosaria, Oolina and Vasiglobulina. With the exception of some species of Fissurina and Lagena and the genus Vasiglobulina, all are widely distributed (Table 5). In terms of abundance $>10 \%$ (Table 4 ) there are no examples in Groups 1-3, Guttulina is present in 4, and the rest are in 5 or 6 so they are generally of very low abundance. The main environments are shelf and deep sea but some species extend into fjord, marginal marine and marsh (in low abundance in the latter) (Table 2).

\section{Opportunists and generalists}

The terms 'opportunist' and 'generalist' are sometimes applied to species. These terms are subjective adjectives not based on precise measurement. It is simple to recognize extreme examples but it is not easy to classify the majority of species that fall in the middle of the range.

An opportunist is able to spread into a new habitat or rapidly increase its numbers in response to an environmental change. A clear example is Stainforthia fusiformis which rapidly responds to an increase in food beneath a hydrodynamic front and also to the early recovery of a previously anoxic environment (Alve, 2003). Textularia earlandi is also said to be an opportunist (Alve \& Goldstein, 2010). The species listed in Group 1 in Table 4 may be opportunists.

A generalist species tolerates a wide range of environmental conditions and is less responsive to rapid environmental changes; this probably applies to the majority of species. Generalists may be widely or narrowly distributed but opportunists are likely to be widely distributed.

One of the keys to being opportunistic or a generalist is reproduction. Some species reproduce throughout the year (e.g. Haynesina germanica; Murray \& Alve, 2000a) while others do so annually (Elphidium crispum; Lister, 1895). Some other very rare species may reproduce only when conditions are favourable (e.g. sufficient food). This leads to a short-lived 'bloom' in abundance and may be on a time-scale longer than one year. This may be the case for Group 5 abundance (Table 4; Fig. 3) because the majority of abundances are very low. The forms in Group 6 either never produce many offspring when they do reproduce or else they reproduce so rarely that it has yet to be recorded. If the availability of food is the main control on the onset of reproduction then to a certain extent even rare species may be considered opportunistic, albeit on a modest scale.

\section{Summary of the ecological controls noted for the species discussed}

All species distributions are characterized by many zero occurrences and these have been ignored in compiling the data. It is evident that there is great variability in abundance in some taxa, as can be seen from the mean and maximum values of abundance (Table 3). The presence or absence of a species is likely to be controlled by many interdependent factors but the extent of that interdependence has not yet been determined for any species. Therefore, authors discuss each factor separately. Nevertheless, it must always be borne in mind that different factors may be more important at different times or in different areas.

The ecological controls include biotic (quantity and type of food, competition, predation, availability of phytal or other substrates elevated above the sea floor), abiotic (salinity, temperature, oxygen levels in the bottom water and sediment, tides/currents, substrate) and biotic/abiotic disturbance brought about by organisms affecting the substrate (bioturbation, trails). The ecological notes accompanying the species distributions bring together comments from various authors and list the citations.

In recent years the role of food as an ecological control has received much attention. Although many different types of feeding have been postulated, most discussion concerns the availability of plant food (see Murray, 2006). It must be assumed that there is always a 'hidden' bacterial element in all food resources (Lee, 1980). Higher plant detritus is essential for marsh dwellers. Intertidal and shallow-water forms feed primarily on benthic food (diatoms and other algae) whereas in deep water, where such food resources cannot grow, phytoplankton (phytodetritus) is the major source (Gooday, 2002). Some species seem to prefer fresh material (Eggerelloides medius, Textularia earlandi, Fursenkoina apertura, Pullenia osloensis, Stainforthia fusiformis), others degraded material (Eggerella europea, Haplophragmoides bradyi) and others are less specific (Melonis barleeanum). At present there is no information on whether specific phytoplankton species are preferred. The range and optimum supply of organic carbon is given for some of the species discussed (Altenbach et al., 1999).

Salinity is clearly a control on many species; for stenohaline taxa the salinity must be $\sim 35$ and for euryhaline taxa each species has its preferred range. For example, Haynesina germanica tolerates an extreme range (0-35) yet its absence from areas of permanently very low salinity may be because it needs salinity to exceed a certain minimum in order to reproduce. Salinity is a significant control between some major environments (marsh, marginal marine, fjords and shelf, deep sea). Temperature is a significant factor for many shallow-water taxa; cold water forms include Astrononion gallowayi and Nonionellina labradorica; and there are temperature thresholds that affect reproduction (e.g. as shown experimentally for Patellina corrugata). Temperature controls the latitudinal distribution of marsh to shelf taxa. Bottom waters and subsurface sediments low in oxygen exclude many taxa but there are some that are adapted to tolerate such 
conditions (e.g. Fursenkoina pontoni, Reussella spinulosa, Stainforthia fusiformis). There are major differences in the faunas of different sediment types. Trifarina angulosa is especially abundant in coarse sands/gravels along shelf edges subject to currents. Stainforthia fusiformis is a mud dweller.

\section{Ecological significance of rare species}

As already noted, even species that are abundant through part of their range (Groups 1-5, Table 4) will be rare towards the limits of their distribution but here we are concerned with species that are always rare (Group 6). Rare species and high diversity are interlinked. In any given assemblage some of the rare species will be from the marginal distributions of Groups 1-5 and some from Group 6. Since higher diversities are a feature of shelf seas and deep sea it follows that the majority of Group 6 rare species feature in these environments.

We can pose various questions: why are they always rare? How do they manage to continue to be present while being rare? How do they maintain genetic exchange with such dispersed and discontinuous distributions? Rarity cannot be an adaptive strategy nor can it arise through natural selection (Rabinowitz, 1981). Gaston (1997, p. 39) considers 'The extent to which rare species remain rare in space and time is arguably a pivotal question in community biology'.

From a practical point of view the opportunity to reproduce is fundamental to survival. Benthic foraminifera reproduce both sexually and asexually. In the former the need for individuals to meet, the size of the standing crop and of $3 \mathrm{D}$ space may place limitations on the chances of meeting. What is the size of spacing beyond which individuals of a given species are unlikely to meet to reproduce? What are the controls on timing of sexual reproduction for individuals of the same species? There are no such restrictions for asexual reproduction. The latter could be synchronous or random - it would make no difference except that synchronous reproduction would give a greater chance of a species having a period of high abundance. Kunin (1997) noted that in land plants all rare species show disproportionately high levels of asexuality. In benthic foraminifera asexual reproduction is often more frequent than sexual. Asexual reproduction is certainly potentially advantageous when individuals are widely dispersed from one another. However, it is not known whether rare foraminiferal species preferentially reproduce asexually.

One attribute of widely distributed rare species is that they must be broadly tolerant of small-scale environmental variability yet species with small populations are more sensitive to disturbance and more likely to local extinction according to Gilpin \& Soulé (1986). The role of disturbance in promoting opportunity was first proposed by Grassle \& Sanders (1973) and is now recognized to be very significant. The biodiversity of soft-bottomed communities is much influenced by 'ecosystem engineers' that alter the sea floor and create microhabitats for meiofauna, e.g. bioturbators providing not only burrows but also bio-irrigation of sediment, or taxa building elevated structures, such as reefs or macroalgae, which provide substrates for colonization (Heip et al., 2003). Such activity is of potential significance to benthic foraminifera. They also stress the role of microorganisms in the remineralization of organic matter. One has only to examine fresh muddy sediment under a microscope to see how mucus secreted as a lubricant by molluses and other benthos holds together fine sedimentary particles which are not otherwise already incorporated in faecal pellets, yet its importance is rarely mentioned. Even at the scale of foraminifera, infaunal taxa create tiny burrows and move detrital particles. This may not be of consequence to larger organisms but it could affect microbial activity. These processes were summarized by Schönfeld et al. (2011, p. 199) 'patchy food input and physical disturbance creates a patchiness to maintain the sea floor as a series of small-scale successional mosaics, which as a whole promote a comparatively high diversity'. Minor differences in the patches may provide a range of microhabitats that individually suit particular rare species. That we cannot specify the precise ecological requirements of rare species is not surprising since the same applies to common species.

There is a view that only a few species are needed for an ecosystem to function and, therefore, most species are redundant. This concept is important for understanding the significance of rare species. If they are redundant, lost species could be replaced without having much impact on the ecosystem. An alternative view is the rivet hypothesis that proposes that interspecific connections mean that every species has some effect on the functioning of an ecosystem. The third alternative is the idiosyncratic response hypothesis which suggests that addition or loss of species will lead to unpredictable changes in the function of an ecosystem (see review by Graf, 2003).

In a review of the diversity-stability concept, McCann (2000) concluded that, on average, diversity gives rise to ecosystem stability; but diversity is not the driver; instead ecosystem stability depends on species that are capable of differential response. There is still great uncertainty about the consequences either of the loss of a species by local extinction or how gain of a species by invasion will affect an ecosystem. As pointed out by Heip et al. (2003, p. 294) 'The overall question is how many species and functional groups are needed to sustain a stable ecosystem'. None of this discussion is specially targeted at rare species. Nevertheless, one must consider what level of reduction in a rare species distribution will ultimately lead to its local or global extinction. In general most attention is paid to changes in abundance of dominant species in monitoring pollution using foraminifera (see examples in Murray \& Alve, 2002) but it is often the rare species that die out with increasing stress. It has been argued that rare species are important in community studies and critical for bioassessment (Cao et al., 1998).

\section{Differences between macroorganisms and microorganisms}

The distribution of organisms reflects their evolution, ecology, means of or ability to disperse and the consequences of plate tectonic rearrangements through time. A recent conference on the biogeography of microscopic organisms addressed these problems (Fontaneto, 2011). It discussed the theoretical background and examined the distribution of mainly soft-bodied terrestrial groups but also shelled diatoms and testate amoebae. Among the topics discussed was the controversial proposal by Finlay (2002) that there is a size threshold of $2 \mathrm{~mm}$ above which there are macroorganisms which show distinct biogeographical patterns and below which there are microorganisms which occur everywhere ('ubiquity hypothesis' or everything is everywhere, EiE, hypothesis) but 
only where the environment is suitable ('the environment selects'). This latter assertion is based on the idea that all microorganisms have resting stages that can colonize an environment if it changes to become favourable for any given species. A second problem concerns the use of morphospecies as the basic taxonomic unit. Most of the microorganisms studied lack hard parts and morphospecies are, therefore, less clearly defined than is the case for foraminifera which are primarily meiofaunal but mainly $<2 \mathrm{~mm}$ in size. Molecular genetic studies are used to determine genetically-based phylospecies which may also be recognized morphospecies, cryptic species within a morphospecies or totally new species as yet undescribed. In monothalamous forms with organic or agglutinated tests from the Arctic and Antarctic, Pawlowski \& Holzmann (2008) found 12 unnamed phylotypes with restricted geographical distributions. However, three deepsea morphospecies (Cibicidoides wuellerstorfi, Epistominella exigua, Oridorsalis umbonatus) show high genetic similarity (Pawlowski et al., 2007). Such results have consequences for evolutionary and ecological applications of biogeography. The overall conclusions of the conference were that

Given the complexity of the spatial patterns in microorganisms, it seems that their biogeography is more likely to depend on a complex set of interacting phenomena, in which size is of course important, but it is not the only driver. The differences between micro- and macroorganisms can thus be included in a gradient, disregarding the hypothesised abrupt threshold assumed by the EiE hypothesis. (Fontaneto, 2011, p. 9).

The results from this study clearly demonstrate that benthic foraminifera are not present everywhere; even widely distributed species are restricted to parts of oceans and to specific environments. Unlike most biogeographical studies, which are concerned with groups of morphospecies, the focus of this study has been to establish the pattern for individual species. Some abiotic parameters may exert an obvious control, such as temperature differences favouring cool- or warm-water species. Even then there are subtle differences in the response to temperature; some species are more cold-tolerant than others (e.g. Eggerelloides medius compared with Eggerelloides scaber). Since each species has its own distinct niche controlled by a plexus of factors it is to be expected that each distribution will be different and that appears to be the case in the results presented here. Further studies of biogeography and ecology will be mutually beneficial and there will be significant input from molecular genetic studies as more phylotypes are recognized.

\section{Applications}

This review brings together ecological data on a wide range of morphospecies and their distributions which throw new light on ecology and will be of value in palaeoecological interpretations. It also has consequences for taxonomy: recognizing possible misidentifications for isolated records of species outside their normal range and also for questioning whether bipolar distributions are truly of single morphospecies or of two separate morphospecies or even cryptic species. Only genetic studies can resolve that problem.

\section{CONCLUSIONS}

This is the first attempt to gather virtually all the available data on live/stained benthic foraminifera to: (a) establish the pattern of relative abundance with respect to number of occurrences, and (b) establish the full environmental range and relative abundance of $>120$ taxa in each major environment. It is the most detailed investigation of global biogeographical distributions of individual benthic foraminiferal morphospecies. There are a number of main conclusions.

- All species have some very low abundance but only a subset has some high abundance.

- There is a continuum of six groups of species with relative abundance/number of occurrences from the extremes of very high abundance $(>40 \%$ of samples with $>10 \%$ abundance) to very low (no samples with $>10 \%$ abundance).

- Although most species may be predominant in one major environment they also extend into other environments. In an extreme case they span from marsh to deep sea (e.g. Eggerella advena, Cornuspira involvens).

- Few species are restricted to a single major environment (usually either marsh, e.g. Balticammina pseudomacrescens, or deep sea, e.g. Gyroidina altiformis, Laticarinina pauperata).

- There are widely distributed species (present in several oceans, e.g. Jadamminia macrescens) and narrowly distributed species (confined to part of a single ocean, e.g. Trochammina pacifica).

- There is no correlation between species abundance and narrow distribution; there are narrowly distributed species in all six abundance groups.

- Not all widely distributed taxa have some areas of high abundance, e.g. Astacolus.

- Some widely distributed taxa are both rare in abundance and found in only a tiny proportion of the samples analysed (often $<1 \%$ ), e.g. Ehrenbergina.

- Disjunct patterns of distribution have implications for taxonomy: are they truly single species (e.g. bipolar distribution of Pullenia osloensis)?

- Some disjunct patterns may be due to misidentification (where there is a single record from an area distant from all other occurrences). These require further investigation.

- Propagules are the most likely mechanism of dispersal of species along the margins and across an ocean as well as between oceans.

- The restriction of some species to a segment of an ocean may be because they lack the ability to produce propagules and, therefore, are not easily dispersed.

- Generalists may be widely or narrowly distributed but opportunists are likely to be widely distributed.

- It is the presence of rare species that contributes to high species diversity.

- Group 6 rare species are found mainly in shelf seas and the deep sea.

- Widely distributed rare species must be broadly tolerant of small-scale environmental variability.

- Minor differences in microhabitats may suit individual rare species.

- These results have implications for ecology, palaeoecological interpretations and taxonomy. 


\section{APPENDIX}

\section{Biogeography and comments on species ecology}

The biogeographical plots are given in a series of figures (Figs 4-95). In these figures the areas with no data are light grey (blue online), present with a mean $>1 \%$ is dark grey (red online), Max indicates the area with the highest relative abundance, * denotes mean $<1 \%$, and absence is unshaded. Where a species is missing from an entire section of the figure (e.g. East or West Atlantic or Rest of World) then that section is omitted to save space. In a few cases there is an additional graph showing the distribution of abundance with respect to environment (Figs 58, 93, 94). Comments on species ecology are from the literature and are provided to help explain the distributions. The sources of data are given in Supplementary Publication tables 3-7 (agglutinated), 8 (porcelaneous) and 9-18 (hyaline). For those species with low abundance in the deep sea information is given on the deepest occurrences.

\section{Agglutinated taxa}

Ammoastuta inepta. The range of this species is primarily in the Gulf of Mexico where it occurs on marshes in Mississippi and Texas, USA, in a lagoon in Mexico, and rarely on the Mississippi shelf. It has also been recorded as rare infaunal $(2-4 \mathrm{~cm})$ in North Carolina marshes, USA (Culver \& Horton, 2005).

Ammobaculites agglutinans. The main environment is deep sea and shelf (Fig. 4). In the Weddell Sea it is infaunal to $3.5 \mathrm{~cm}$ (Mackensen \& Douglas, 1989). The occurrences in fjord and marginal marine may be incorrect identifications. It occurs where the mean sea floor organic $\mathrm{C}$ flux is $7 \mathrm{~g} \mathrm{~m}^{2} \mathrm{a}^{-1}$ (Altenbach et al., 1999).

Ammobaculites balkwilli. Two distinctive features of this species are the circular cross-section of the uniserial part and its habit of incorporating dark sedimentary particles into its wall. Although it was first described from a marsh and has since been recorded in another marsh (Arcachon, France, Le Campion, 1970, as A. agglutinans) the main occurrences are in marginal marine settings from shallow subtidal to low intertidal (Alve \& Murray, 1994). It is restricted to the NE Atlantic (Fig. 5). The range of salinity tolerated in marginal marine southern Scandinavia is 15-29 (Alve \& Murray, 1999).

Ammobaculites dilatatus. Most occurrences are marginal marine or marsh, mainly in the West Atlantic but it is also present in the Pacific (Fig. 6). There are minor occurrences on the shelf off North Carolina and Texas, USA. It occurs infaunally to $8 \mathrm{~cm}$ off North Carolina (Lueck \& Snyder, 1997).

Ammobaculites exiguous. Most occurrences are marsh but it is also present on the shelf off North Carolina and Texas, USA, and there are a few records from marginal marine settings (Fig. 7). It is absent from the East Atlantic and the Indian Ocean. It is infaunal down to $8 \mathrm{~cm}$ on the shelf (Murosky \& Snyder, 1994) and to $10 \mathrm{~cm}$ in a marsh (Steineck \& Bergstein, 1979).

Ammobaculites filiformis. With the exception of a single record from the shelf off Cape Hatteras this is known exclusively from the deep sea of the Atlantic and Pacific oceans (Fig. 8).

Ammoscalaria runiana. This species has a very restricted distribution with the majority of occurrences in marginal marine, some
Ammobaculites agglutinans

EAST ATLANTIC
\begin{tabular}{|c|c|c|c|c|c|c|}
\hline$\sim$ lat. N-S & Area & Marsh & Marg mar & Fjords & Shelf & Deep sea \\
\hline & Arctic Ocean & & & & & \\
\hline $70-60$ & N \& W Norway & & & & & \\
\hline 65 & Iceland-Norwegian Sea & & & & & \\
\hline $55-59$ & S Scandinavia/Baltic & & & & & \\
\hline 56 & Seas around UK & & $x$ & & & \\
\hline $43-45$ & Biscay & & & & & \\
\hline 39 & Portugal & & & & & \\
\hline 43 & W Mediterranean & & & & & \\
\hline 45 & E Mediterranean & & $x$ & & & \\
\hline 20 & NW Africa & & & & & \\
\hline 0 & Gulf of Guinea & & & & & \\
\hline $10-30$ & S Atlantic & & & & & \\
\hline $35-56$ & S Atlantic & & & & & \\
\hline
\end{tabular}

WEST ATLANTIC
\begin{tabular}{|c|c|c|c|c|c|c|}
\hline$\sim$ lat. N-S & Area & Marsh & Marg mar & Fjords & Shelf & Deep sea \\
\hline 70 & E Greenland & & & & & \\
\hline 73 & Arctic Canada & & & & & \\
\hline $50-43$ & Canada & & & & & \\
\hline $45-40$ & E USA & & & & & \\
\hline $40-25$ & E USA & & & & & \\
\hline 30 & N Gulf of Mexico & & & & & \\
\hline $25-18$ & S Gulf of Mexico & & & & & \\
\hline $18-12$ & Caribbean Sea & & & & & \\
\hline 5 & French Guiana & & & & & \\
\hline $24-31$ & Brazil & & & & & \\
\hline $38-54$ & Argentina & & & & & \\
\hline 58 & Scotia Sea & & & & & Max \\
\hline 67 & Weddell Sea & & & & & \\
\hline
\end{tabular}

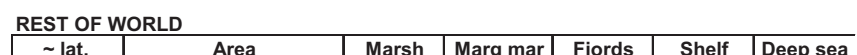

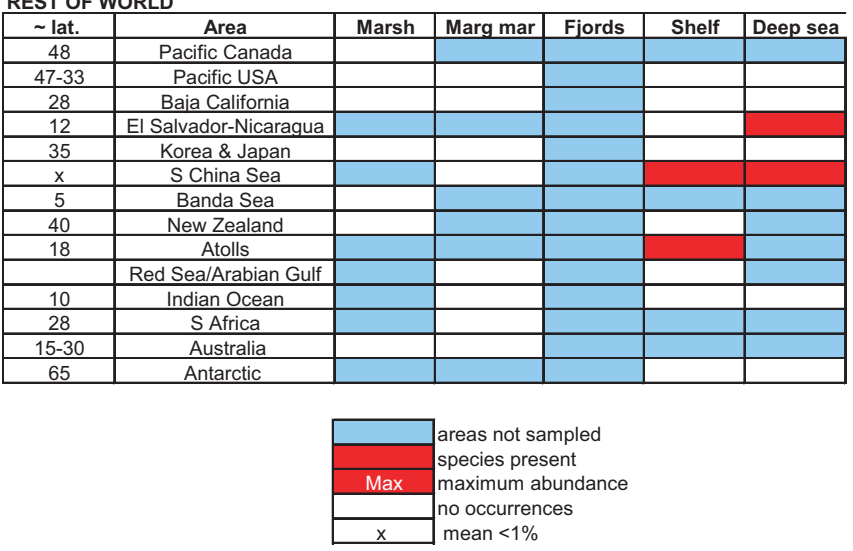

Fig. 4. Ammobaculites agglutinans. Key to symbols: areas with no data are light grey (blue online), present with a mean $>1 \%$ is dark grey (red online), Max indicates the area with the highest relative abundance, *indicates mean $<1 \%$, and absence is unshaded.

Ammobaculites balkwilli
\begin{tabular}{|c|c|c|c|c|c|c|}
\hline$\sim$ lat. N-S & Area & Marsh & Marg mar & Fjords & Shelf & Deep sea \\
\hline & Arctic Ocean & & & & & \\
\hline $70-60$ & N \& W Norway & & & & & \\
\hline 65 & Iceland-Norwegian Sea & & & & & \\
\hline $55-59$ & S Scandinavia/Baltic & & Max & & & \\
\hline 56 & Seas around UK & & & & & \\
\hline $43-45$ & Biscay & & & & & \\
\hline 39 & Portugal & & & & & \\
\hline 43 & W Mediterranean & & & & & \\
\hline 45 & E Mediterranean & & & & & \\
\hline 20 & NW Africa & & & & & \\
\hline 0 & Gulf of Guinea & & & & & \\
\hline $10-30$ & S Atlantic & & & & & \\
\hline $35-56$ & S Atlantic & & & & & \\
\hline
\end{tabular}

Fig. 5. Ammobaculites balkwilli.

fjord, with rare records in marsh and shelf. In southern Scandinavian marginal marine environments it is common only on sediments with $<20 \%$ mud, a median diameter of medium to fine sand, and low total organic carbon (TOC, 0.2-0.7\%) (Alve \& Murray, 1999). It is confined to the NE Atlantic and Baltic Sea (Fig. 9). 

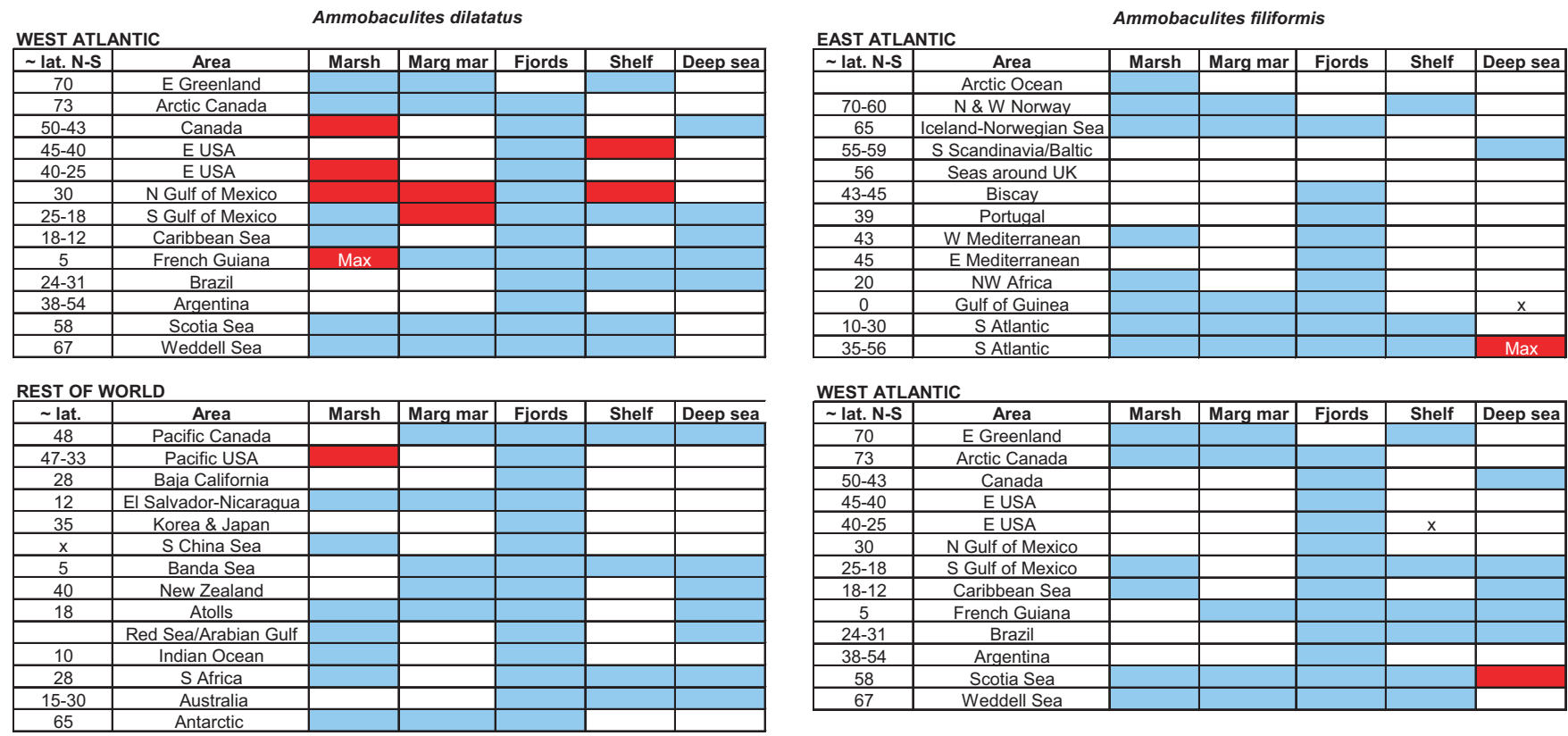

Fig. 6. Ammobaculites dilatatus.
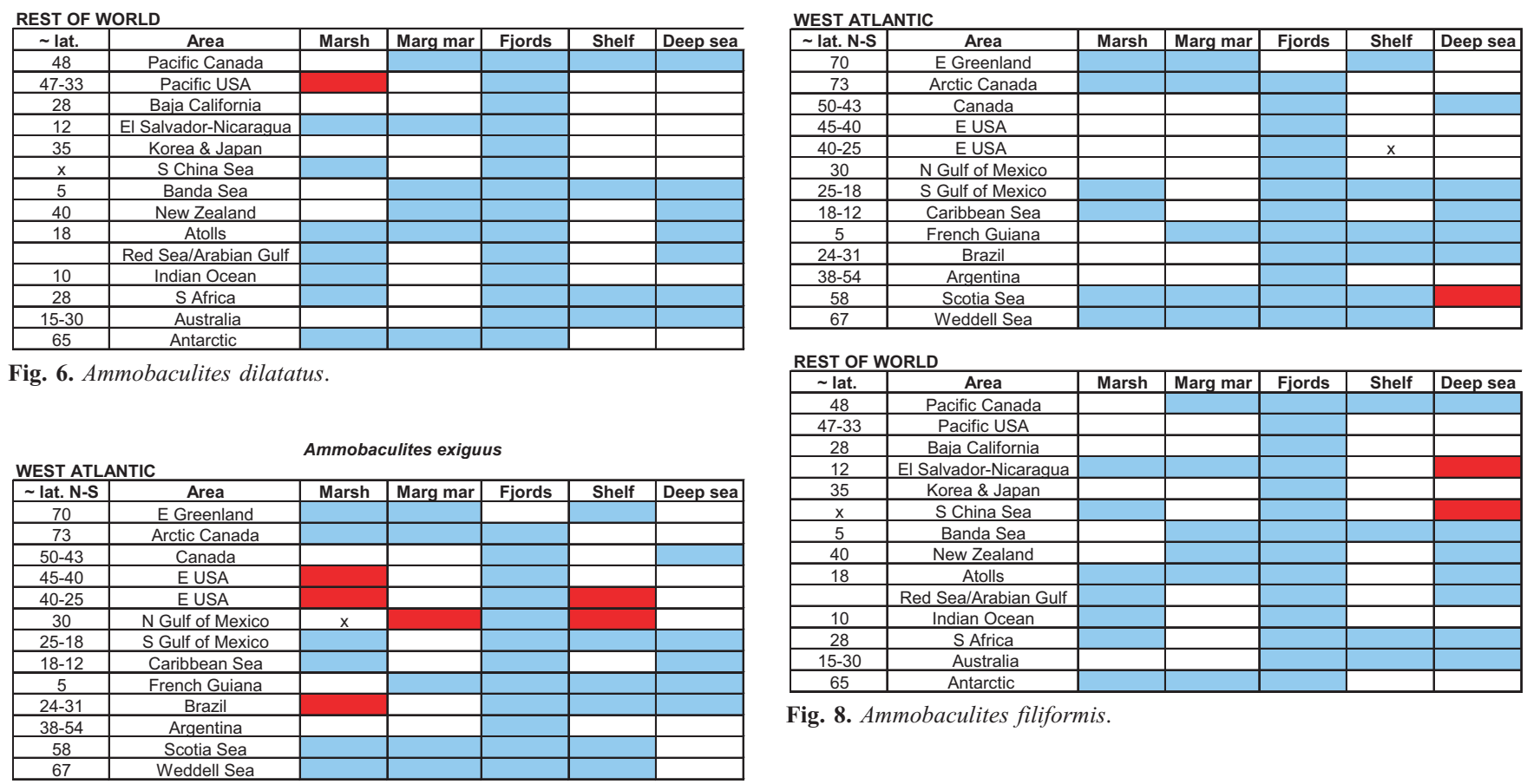

Fig. 8. Ammobaculites filiformis.

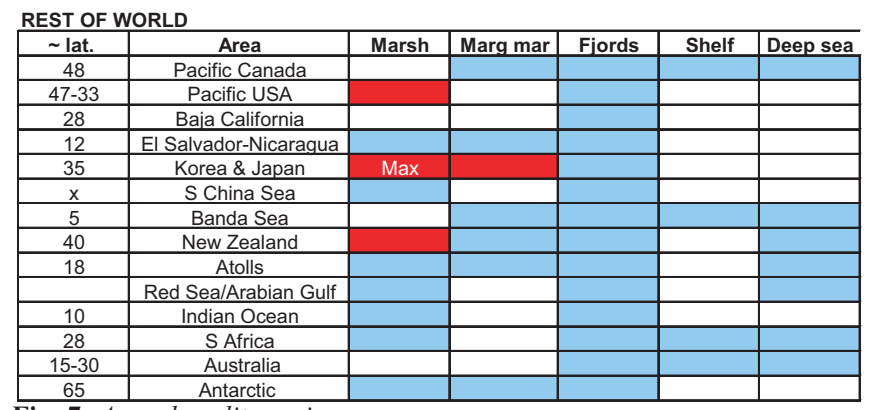

Fig. 7. Ammobaculites exiguus.

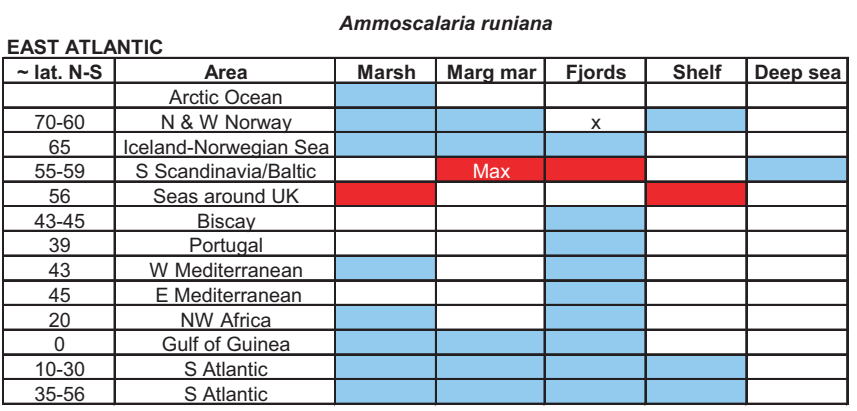

Fig. 9. Ammoscalaria runiana.

Ammotium salsum. This species occurs in the Atlantic, Mediterranean and Pacific oceans (Fig. 10). It is abundant in marsh and marginal marine environments with a few occurrences on the shelf. In some instances it forms monospecific assemblages (brackish to hypersaline marsh, Texas, USA, S 2-42 (Phleger, 1966) and very brackish lagoon, S $0-10$, in Mexico (Phleger \& Lankford, 1978)). The range of salinity tolerated in marginal marine southern Scandinavia is 15-27 (Alve \& Murray, 1999). It has been shown to be infaunal $(0-10 \mathrm{~cm})$ in North Carolina marshes, USA (Culver \& Horton, 2005). In the NE Atlantic and Mediterranean it is much less widespread in marginal marine environments than it is in the West Atlantic and Gulf of Mexico. In the Adriatic it shows a high correlation with the density of sea grass and also with specific diatoms as a food resource but rejects blue-green algae (Hohenegger et al., 1989). In the Gulf of Mexico it extends on to the shelf adjacent to the Mississippi delta. It is a detritivore feeding on bacteria (Matera \& Lee, 1972).

Arenoparrella mexicana. A dominantly marsh species it is also found in marginal marine lagoons especially on the western side of the North Atlantic. Occurrences in the NE Atlantic are restricted to France; it is infrequent in South America and the 
Ammotium salsum

EAST ATLANTIC
\begin{tabular}{|c|c|c|c|c|c|c|}
\hline$\sim$ lat. N-S & Area & Marsh & Marg mar & Fjords & Shelf & Deep sea \\
\hline & Arctic Ocean & & & & & \\
\hline $70-60$ & N \& W Norway & & & & & \\
\hline 65 & Iceland-Norwegian Sea & & & & & \\
\hline $55-59$ & S Scandinavia/Baltic & & & & & \\
\hline 56 & Seas around UK & & & & & \\
\hline $43-45$ & Biscay & & & & & \\
\hline 39 & Portugal & & & & & \\
\hline 43 & W Mediterranean & & & & & \\
\hline 45 & E Mediterranean & & & & & \\
\hline 20 & NW Africa & & & & & \\
\hline 0 & Gulf of Guinea & & & & & \\
\hline $10-30$ & S Atlantic & & & & & \\
\hline $35-56$ & S Atlantic & & & & & \\
\hline
\end{tabular}

WEST ATLANTIC
\begin{tabular}{|c|c|c|c|c|c|c|}
\hline$\sim$ lat. N-S & Area & Marsh & Marg mar & Fjords & Shelf & Deep sea \\
\hline 70 & E Greenland & & & & & \\
\hline 73 & Arctic Canada & & & & & \\
\hline $50-43$ & Canada & & & & & \\
\hline $45-40$ & E USA & & & & & \\
\hline $40-25$ & E USA & & & & & \\
\hline 30 & N Gulf of Mexico & Max & & & & \\
\hline $25-18$ & S Gulf of Mexico & & Max & & & \\
\hline $18-12$ & Caribbean Sea & & $x$ & & & \\
\hline 5 & French Guiana & & & & & \\
\hline $24-31$ & Brazil & & & & & \\
\hline $38-54$ & Argentina & & & & & \\
\hline 58 & Scotia Sea & & & & & \\
\hline 67 & Weddell Sea & & & & & \\
\hline
\end{tabular}

REST OF WORLD
\begin{tabular}{|c|c|c|c|c|c|c|}
\hline$\sim$ lat. & Area & Marsh & Marg mar & Fjords & Shelf & Deep sea \\
\hline 48 & Pacific Canada & & & & & \\
\hline $47-33$ & Pacific USA & & & & & \\
\hline 28 & Baja California & & & & & \\
\hline 12 & El Salvador-Nicaragua & & & & & \\
\hline 35 & Korea \& Japan & & & & & \\
\hline $\mathrm{X}$ & S China Sea & & & & & \\
\hline 5 & Banda Sea & & & & & \\
\hline 40 & New Zealand & & & & & \\
\hline 18 & Atolls & & & & & \\
\hline & Red Sea/Arabian Gulf & & & & & \\
\hline 10 & Indian Ocean & & & & & \\
\hline 28 & S Africa & & & & & \\
\hline $15-30$ & Australia & & & & & \\
\hline 65 & Antarctic & & & & & \\
\hline
\end{tabular}

Fig. 10. Ammotium salsum.

Pacific (Fig. 11). Infaunal down to $2 \mathrm{~cm}$ in New England marshes (Saffert \& Thomas, 1998), and in Georgia, USA, it is patchy in surface sediments of the low marsh but infaunal down to $30 \mathrm{~cm}$ in moist high marsh sediments (Goldstein \& Harben, 1993). It is found infaunal down to $50 \mathrm{~cm}$ in an Australian mangal (Berkeley et al., 2008).

Balticammina pseudomacrescens. There has been some taxonomic confusion surrounding this species. It is recorded as Trochammina macrescens f. macrescens by Scott and as T. macrescens type A by De Rijk \& Troelstra (1999) (see Alve \& Murray, 1999). This is one of the few species found exclusively in a single environment, highest marsh: in the NE Atlantic from southern Scandinavia to southern England, West Atlantic from Canada (where it reaches it greatest abundance) to the northern Gulf of Mexico, then a gap past Brazil to Argentina. In the Pacific Ocean it is known from California, USA, and Japan (Fig. 12). It is epifaunal and associated with damp, rotting leaf litter (Alve \& Murray, 1999) and is an extremely low-salinity euryhaline species.

Eggerella Cushman, 1935 and Eggerelloides Haynes, 1973. The Mesozoic genus Verneuilina d'Orbigny, 1839, was used by nineteenth- and early twentieth-century workers for triserial forms that have now been assigned to other genera, such as Eggerella and Eggerelloides. Loeblich \& Tappan (1987) place Verneuilina in the
Arenoparrella mexicana

EAST ATLANTIC
\begin{tabular}{|c|c|c|c|c|c|c|}
\hline$\sim$ lat. N-S & Area & Marsh & Marg mar & Fjords & Shelf & Deep sea \\
\hline & Arctic Ocean & & & & & \\
\hline $70-60$ & N \& W Norway & & & & & \\
\hline 65 & Iceland-Norwegian Sea & & & & & \\
\hline $55-59$ & S Scandinavia/Baltic & & & & & \\
\hline 56 & Seas around UK & & & & & \\
\hline $43-45$ & Biscay & & $x$ & & & \\
\hline 39 & Portugal & & & & & \\
\hline 43 & W Mediterranean & & & & & \\
\hline 45 & E Mediterranean & & & & & \\
\hline 20 & NW Africa & & & & & \\
\hline 0 & Gulf of Guinea & & & & & \\
\hline $10-30$ & S Atlantic & & & & & \\
\hline $35-56$ & S Atlantic & & & & & \\
\hline
\end{tabular}
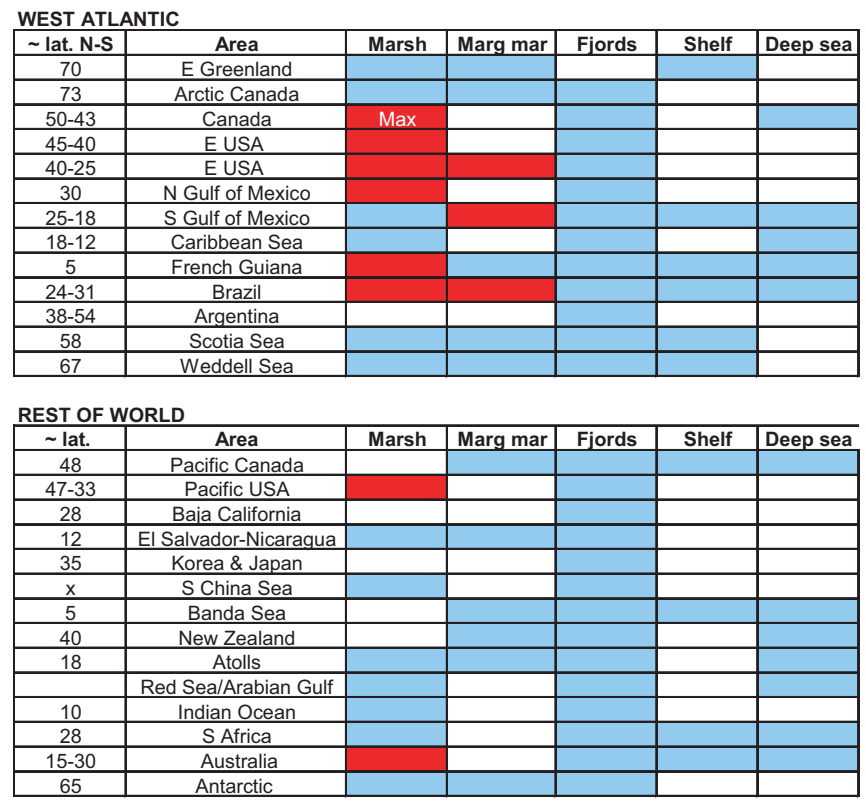

Fig. 11. Arenoparrella mexicana.

Superfamily Verneuilinacea and Eggerella and Eggerelloides in the Textulariacea. In both superfamilies the wall is said to be canaliculate yet this is not true for all species assigned to Eggerella or for Eggerelloides. However, when Cushman erected the genus Eggerella he described the wall as having calcareous cement but made no mention of canaliculae.

The type species of Eggerella is Verneuilina bradyi Cushman, 1911. This is a deep-sea form with a canaliculate wall and calcareous cement. This is not the case for Eggerella advena so the reason for placing the species advena in this genus is not clear but perhaps Cushman did not consider the nature of the cement to be a significant taxonomic feature. Eggerelloides was erected by Haynes (1973) with the type species Bulimina scabra Williamson, 1858. Like Eggerella advena it has an agglutinated wall with organic cement. The aperture of the former is a low arch at the base of the apertural face, whereas that of Eggerelloides is a high loop-shaped slit extending up the apertural face.

Eggerella advena. Cushman (1922, p. 57) gave as his description: 'Variety differing from the typical in the smaller size and more slender form'. From comments on p. 56 it is clear that 'the typical' is what is now called Eggerelloides scaber. Of the 215 occurrences along the eastern seaboard of North America, 57\% are from marginal marine settings (mainly Long Island Sound, Buzas, 1965), $37 \%$ are on the shelf and the remainder are from marsh 


BAST ATLANTIC
\begin{tabular}{|c|c|c|c|c|c|c|}
\hline$\sim$ lat. N-S & Area & Marsh & Marg mar & Fjords & Shelf & Deep sea \\
\hline & Arctic Ocean & & & & & \\
\hline $70-60$ & N \& W Norway & & & & & \\
\hline 65 & Iceland-Norwegian Sea & & & & & \\
\hline $55-59$ & S Scandinavia/Baltic & & & & & \\
\hline 56 & Seas around UK & & & & & \\
\hline $43-45$ & Biscay & & & & & \\
\hline 39 & Portugal & & & & & \\
\hline 43 & W Mediterranean & & & & & \\
\hline 45 & E Mediterranean & & & & & \\
\hline 20 & NW Africa & & & & & \\
\hline 0 & Gulf of Guinea & & & & & \\
\hline $10-30$ & S Atlantic & & & & & \\
\hline $35-56$ & S Atlantic & & & & & \\
\hline
\end{tabular}
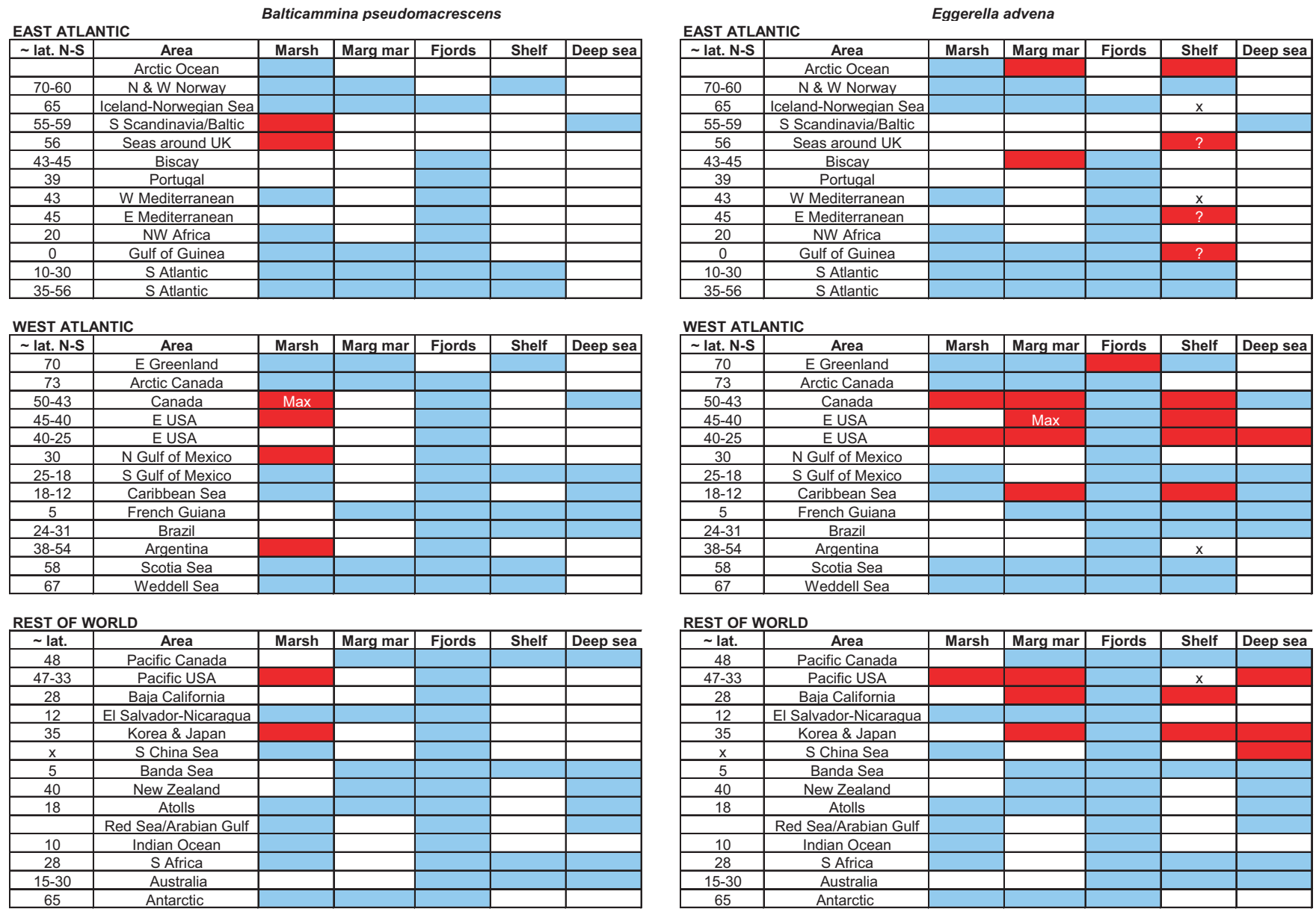

Fig. 12. Balticammina pseudomacrescens.

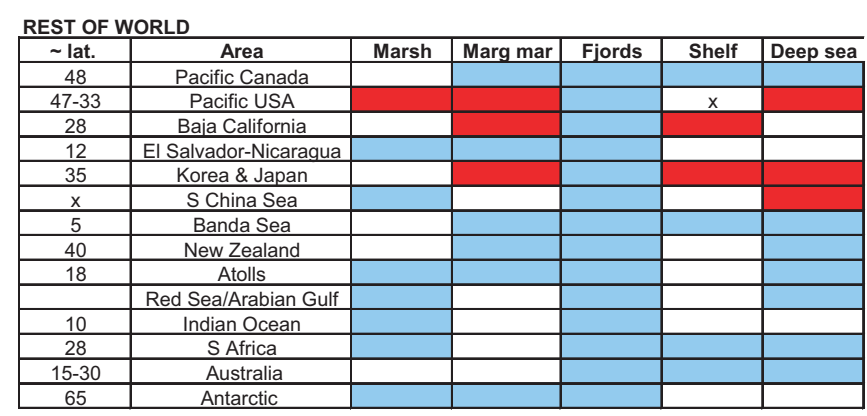

Fig. 13. Eggerella advena.

and fjord. These are all from cool waters derived from the north. The salinity in Long Island Sound is 25-29 and on the open shelf it is $32-35$. Buzas (1965) considered that the abundance of $E$. advena is probably related to food supply. There are only 5 occurrences in the Caribbean (Jamaica, Puerto Rico) and the identification of these may not be correct.

Along the Arctic, Atlantic and Mediterranean coasts of Europe E. advena has been reported mainly from the shelf $(97 \%$ of 168 occurrences) (Fig. 13). It is likely that some of the identifications are suspect. Scott et al. (2003) recorded it in the Celtic Sea (30 samples). However, the author has never seen it there although Eggerelloides scaber is present. Daniels (1970) separated E. advena from E. scaber in the Adriatic Sea on the basis that the former was mainly half the size of the latter. Since both species were recorded in 115 samples it may be that they are really one and that is likely to be $E$. scaber with the juveniles being reported as advena. Together these two instances account for $86 \%$ of the 168 occurrences. The records from the Arctic may be authentic.

On the Pacific seaboard of North America there are 186 occurrences, $67 \%$ of which are from borderland basins (which extend down to $>1000 \mathrm{~m}$ ), $25 \%$ from shelf and the remainder from marsh and marginal marine. Most of the basin occurrences are those of Uchio (1960), who erected the species E. scrippsi on the basis that the wall is composed of finer particles and is smoother than that of E. advena. Nevertheless, he had difficulty separating the two species. Here they are both considered as E. advena.

There are 66 records from Japan. Of these, 26 are from heavily polluted Osaka Bay which has restricted connections with the open sea (Tsujimoto et al., 2006). Over the past 50 years there has been a major faunal change which the authors attribute to the increase in pollution leading to hypoxia and anoxia. However, this species is abundant in Ishikari Bay which is open to the sea and was not reported as polluted or hypoxic at the time of sampling (Ikeya, 1970).

This appears to be a detritivore (Murray, 1991) and to tolerate hypoxic conditions in areas subject to pollution. It is highly mobile (Schafer \& Young, 1977) and was a pioneer species in recolonizing sediment dumped from dredging in Canada (Schafer, 1982). It is infaunal down to $10 \mathrm{~cm}$ off North Carolina (Murosky \& Snyder, 1994).

Eggerella europea. This distinctive small, elongate species was first recorded by Höglund (1947) in Gullmar fjord, Sweden as Verneuilina advena Cushman. It has an organic-cemented wall so does not truly fit in Eggerella. Rare living occurrences are confined to Hardangerfjord, Norway, the Skagerrak and the shelf west of Scotland. In a two-year experiment, where the fauna was deprived of fresh phytodetritus, it increased in abundance, indicating that it feeds on degraded food (Alve, 2010). 


Eggerelloides medius
EAST ATLANTIC
\begin{tabular}{|c|c|c|l|l|c|c|}
\hline$\sim$ lat. N-S & Area & Marsh & Marg mar & Fjords & Shelf & Deep sea \\
\hline & Arctic Ocean & & & & & \\
\hline $70-60$ & N \& W Norway & & & & & \\
\hline 65 & Iceland-Norwegian Sea & & & & & $\times$ \\
\hline $55-59$ & S Scandinavia/Baltic & & & Max & & \\
\hline 56 & Seas around UK & & & & & \\
\hline $43-45$ & Biscay & & & & & \\
\hline 39 & Portugal & & & & & \\
\hline 43 & W Mediterranean & & & & & \\
\hline 45 & E Mediterranean & & & & & \\
\hline 20 & NW Arrica & & & & & \\
\hline 0 & Gulf of Guinea & & & & & \\
\hline $10-30$ & S Atlantic & & & & & \\
\hline $35-56$ & S Atlantic & & & & & \\
\hline
\end{tabular}

Fig. 14. Eggerelloides medius.

Eggerelloides medius. First described from Gullmar Fjord, Sweden, this species was originally confused with E. scaber. Where the two species co-occur care has to be taken to separate them; medius generally has a coarse finish to the wall and is slightly less pointed at the initial end than scaber. Eggerelloides medius lives primarily on the shelf (74\%) and in fjords in Scandinavia $(24 \%)$ with rare occurrences in deeper water (Fig. 14). The shelf occurrences extend from the northern North Sea and Skagerrak to southern England and to the west of Scotland where core records show it down to $3 \mathrm{~cm}$ (the limit of sampling) (Murray, 2003). There are rare records from the deep sea from west Norway down to $856 \mathrm{~m}$ (Mackensen, 1985). Eggerelloides medius is a cool temperate species. It is confined to water depths $>90 \mathrm{~m}$ where some mud is present in the sediment (Murray \& Alve, 2000b). In a fjord (Alve \& Nagy, 1986), in the North Sea (Klitgaard-Kristensen \& Sejrup, 1996) and on the shelf off Scotland (Murray, 2003) it shows a correlation with \% TOC and fine sediment fraction. In a two-year experiment, where the fauna was deprived of fresh phytodetritus, it decreased in abundance, indicating a need for fresh food (Alve, 2010).

Eggerelloides scaber. Particularly common in the NE Atlantic but absent from the West Atlantic (Fig. 15). It occurs in marginal marine, fjord, shelf and deep sea but is most abundant on the shelf, although the single highest abundance is from Oslo fjord. The range of salinity tolerated in marginal marine southern Scandinavia is 19-28 (Alve \& Murray, 1999). It requires a salinity of at least 24 for most of the year in order to flourish and the optimum is 29-35 (Lutze et al., 1983). It may have been more common in the western Baltic in the past but is now found only in higher salinity areas, such as deeper Kiel Bight (Polovodova et al., 2009). It tolerates a broad range of temperature but the optimum may be $15-20^{\circ} \mathrm{C}$ (Murray, 1968). Although it tolerates oxygen levels of $<0.5 \mathrm{ml} \mathrm{l}^{-1}$ it took more than one year for it to colonize sediments recovering from a prolonged period of anoxia (Alve, 1995a). In the Adriatic Sea it occurs in shallow water where there is periodic oxygen deficiency (Donnici \& Serandrei Barbero, 2002). In Drammensfjord, Norway, it is most abundant in the upper part of transitional water masses due to a combination of salinity conditions, increased organic flux and depleted oxygen (Alve, 1990). However, Schönfeld (2001) considers it to be an oxic species based on measurements of pore water oxygen. In the Celtic Sea it correlates with high sand content (Scott et al., 2003). It is tolerant of heavy metal pollution (Frontalini \& Coccioni, 2008). In the deep sea it extends down to a maximum of $1500 \mathrm{~m}$ in the

EAST ATLANTIC
\begin{tabular}{|c|c|c|c|c|c|c|}
\hline$\sim$ lat. N-S & Area & Marsh & Marg mar & Fjords & Shelf & Deep sea \\
\hline & Arctic Ocean & & & & & \\
\hline $70-60$ & N \& W Norway & & & & & \\
\hline 65 & Iceland-Norwegian Sea & & & & & \\
\hline $55-59$ & S Scandinavia/Baltic & & & Max & x & \\
\hline 56 & Seas around UK & & & & & \\
\hline $43-45$ & Biscay & & X & & & \\
\hline 39 & Portugal & & & & & \\
\hline 43 & W Mediterranean & & & & & \\
\hline 45 & E Mediterranean & & & & & \\
\hline 20 & NW Africa & & & & & \\
\hline 0 & Gulf of Guinea & & & & & \\
\hline $10-30$ & S Atlantic & & & & & \\
\hline $35-56$ & S Atlantic & & & & & \\
\hline
\end{tabular}

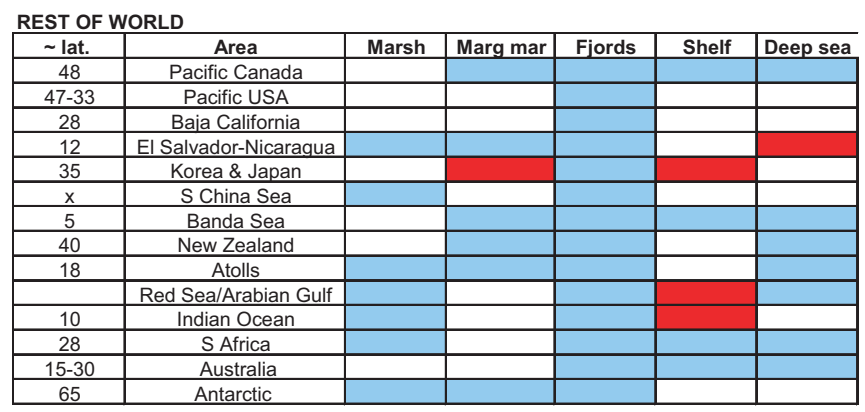

Fig. 15. Eggerelloides scaber.

Gulf of Guinea and, in submarine canyons, down to $920 \mathrm{~m}$ in the Gulf of Lions and $3097 \mathrm{~m}$ in Nazare canyon off Portugal. Some of the deep-sea occurrences might be misidentified juveniles of Liebusella goesi (Alve \& Goldstein, 2010). It is also reported from Japan and the Indian Ocean where it is named E. scaber australis. It is generally infaunal: in the North Sea down to $25 \mathrm{~cm}$ with peak values at 0-7 cm (Moodley, 1990) and in the Adriatic down to $7 \mathrm{~cm}$ but it occurs predominantly in the top $\mathrm{cm}$ where it may reproduce (Barmawidjaja et al., 1992). It is also epiphytic on seagrass (Debenay, 2000; Semeniuk, 2001). It sometimes has green protoplasm (suggesting herbivory) but Alve $\&$ Goldstein (2010) conclude that it is an omnivore.

Gaudryina exilis. This is primarily a marginal marine form but it also occurs on marsh (where it reaches it highest abundance) and shelf. It is absent from the East Atlantic and Pacific. It is present in the warmer parts of the West Atlantic and the Indian Ocean (Fig. 16).

Gaudryina pauperata. On the Pacific margin of North America it occurs on marshes and in marginal marine environments, while off Japan it is found on the shelf. The only record from the Atlantic is from the shelf in the Caribbean (Fig. 17). The single record from the deep sea at $537 \mathrm{~m}$ in the Scotia Sea is almost certainly a misidentification.

Glomospira gordialis. The records span all environments from marsh to deep sea but this is essentially a shelf and deep-sea form (Fig. 18). It is present on shelves in the Arctic, on both sides of the North Atlantic, off California, USA, and Japan. The deep sea records are from the Atlantic Ocean, Scotia Sea and Southern Ocean, Japan and South China Sea. Most abundances are very low and the only location where it exceeds $10 \%$ is a single sample from a lagoon in Brazil (Duleba \& Debenay, 2003). It occurs where the mean sea floor organic $C$ flux is $7-9 \mathrm{~g} \mathrm{~m}^{2} \mathrm{a}^{-1}$ (Altenbach et al., 1999). 

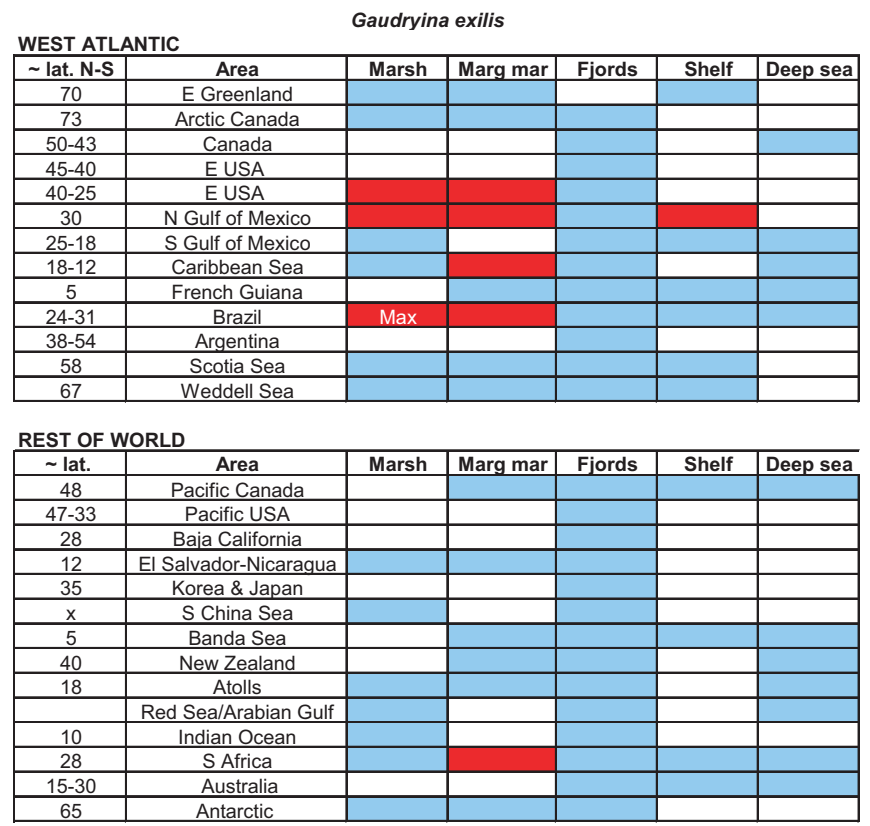

Fig. 16. Gaudryina exilis.
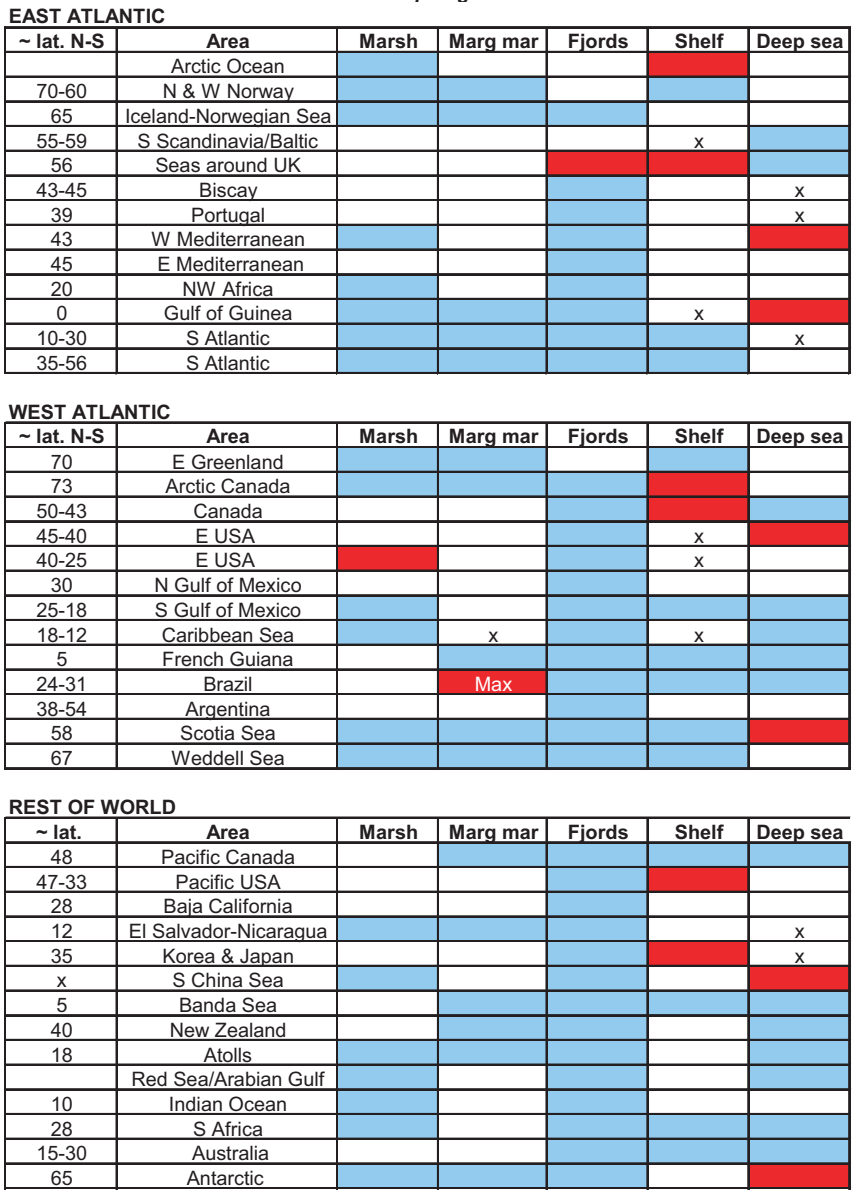

WEST ATLANTIC
\begin{tabular}{|c|c|c|c|c|c|c|}
\hline$\sim$ lat. N-S & Area & Marsh & Marg mar & Fjords & Shelf & Deep sea \\
\hline 70 & E Greenland & & & & & \\
\hline 73 & Arctic Canada & & & & & \\
\hline $50-43$ & Canada & & & & & \\
\hline $45-40$ & E USA & & & & & \\
\hline $40-25$ & E USA & & & & & \\
\hline 30 & N Gulf of Mexico & & & & & \\
\hline $25-18$ & S Gulf of Mexico & & & & & \\
\hline $18-12$ & Caribbean Sea & & & & & \\
\hline 5 & French Guiana & & & & & \\
\hline $24-31$ & Brazil & & & & & \\
\hline $38-54$ & Argentina & & & & & \\
\hline 58 & Scotia Sea & & & & & \\
\hline 67 & Weddell Sea & & & & & \\
\hline
\end{tabular}

REST OF WORLD
\begin{tabular}{|c|c|l|l|l|l|l|}
\hline$\sim$ lat. & Area & Marsh & Marg mar & Fjords & Shelf & Deep sea \\
\hline 48 & Pacific Canada & & & & & \\
\hline $47-33$ & Pacific USA & & & & & \\
\hline 28 & Baja California & & Max & & & \\
\hline 12 & El Salvador-Nicaraqua & & & & & \\
\hline 35 & Korea \& Japan & & & & & \\
\hline$x$ & S China Sea & & & & & \\
\hline 5 & Banda Sea & & & & & \\
\hline 40 & New Zealand & & & & & \\
\hline 18 & Atolls & & & & & \\
\hline & Red Sea/Arabian Gulf & & & & & \\
\hline 10 & Indian Ocean & & & & & \\
\hline 28 & S Africa & & & & & \\
\hline $15-30$ & Australia & & & & & \\
\hline 65 & Antarctic & & & & & \\
\hline
\end{tabular}

Fig. 17. Gaudryina pauperata.

Haplophragmoides bradyi. Although often considered to be a deep-sea form, $H$. bradyi also occurs commonly on the shelf and more rarely in Norwegian fjords (where it has its highest mean value). Most occurrences are in the East Atlantic (Fig. 19) but it also occurs in the Pacific, Indian and Southern oceans. In a twoyear experiment, where the fauna was deprived of fresh phytodetritus, it increased in abundance, indicating that it feeds on degraded food (Alve, 2010).

Haplophragmoides shallow-water species. The common shallowwater species are Haplophragmoides bonplandi, H. manilaensis,

Fig. 18. Glomospira gordialis.

H. subinvolutum and $H$. wilberti. All these forms are morphologically variable so it is uncertain whether there are truly as many species as have been named. Alve \& Murray (1999) noted that their $H$. wilberti included forms regarded as $H$. manilaensis by D.B. Scott (pers. comm.). These four Haplophragmoides species are typical marsh forms (93\% of occurrences) although there are sparse records in marginal marine and shelf settings (Fig. 20). They occur in East and West Atlantic and Pacific oceans. Haplophragmoides wilberti is recorded widely present elsewhere; $H$. bonplandi is found in Canada and North Carolina, USA; $H$. manilaensis in Portugal, eastern USA, Gulf of Mexico, Brazil and Japan; H. subinvolutum Texas, USA, and Pacific USA. Haplophragmoides manilaensis is found down to $2 \mathrm{~cm}$ in New England marshes (Saffert \& Thomas, 1998). The range of salinity tolerated by $H$. wilberti in marginal marine southern Scandinavia is 10-27 (Alve \& Murray, 1999).

Jadammina macrescens. Although a typical marsh species, J. macrescens also occurs in adjacent intertidal marginal marine environments. In the NE Atlantic marshes it extends from southern Scandinavia to Portugal and also into the Eastern Mediterranean (Greece, Italy: Scott et al., 1979). In the West Atlantic it occurs from Canada to the northern Gulf of Mexico; there is a gap until it reoccurs in Brazil and Argentina. Pacific occurrences are from Canada to Baja California, also the Banda 
Haplophragmoides bradyi

EAST ATLANTIC
\begin{tabular}{|c|c|c|c|c|c|c|}
\hline$\sim$ lat. N-S & Area & Marsh & Marg mar & Fjords & Shelf & Deep sea \\
\hline & Arctic Ocean & & & & & \\
\hline $70-60$ & N \& W Norway & & & & & \\
\hline 65 & Iceland-Norwegian Sea & & & & & \\
\hline $55-59$ & S Scandinavia/Baltic & & & & & \\
\hline 56 & Seas around UK & & & & & \\
\hline $43-45$ & Biscay & & & & & $\mathrm{x}$ \\
\hline 39 & Portugal & & & & & \\
\hline 43 & W Mediterranean & & & & & \\
\hline 45 & E Mediterranean & & & & & \\
\hline 20 & NW Africa & & & & & \\
\hline 0 & Gulf of Guinea & & & & & \\
\hline $10-30$ & S Atlantic & & & & & $\mathrm{x}$ \\
\hline $35-56$ & S Atlantic & & & & & $\mathrm{x}$ \\
\hline
\end{tabular}

WEST ATLANTIC
\begin{tabular}{|c|c|c|c|c|c|c|}
\hline$\sim$ lat. N-S & Area & Marsh & Marg mar & Fjords & Shelf & Deep sea \\
\hline 70 & E Greenland & & & & & \\
\hline 73 & Arctic Canada & & & & & \\
\hline $50-43$ & Canada & & & & & \\
\hline $45-40$ & E USA & & & & & \\
\hline $40-25$ & E USA & & & & & \\
\hline 30 & N Gulf of Mexico & & & & & \\
\hline $25-18$ & S Gulf of Mexico & & & & & \\
\hline $18-12$ & Caribbean Sea & & & & & \\
\hline 5 & French Guiana & & & & & \\
\hline $24-31$ & Brazil & & & & & \\
\hline $38-54$ & Argentina & & & & & \\
\hline 58 & Scotia Sea & & & & & $\mathrm{x}$ \\
\hline 67 & Weddell Sea & & & & & \\
\hline
\end{tabular}

REST OF WORLD
\begin{tabular}{|c|c|c|c|c|c|c|}
\hline$\sim$ lat. & Area & Marsh & Marg mar & Fjords & Shelf & Deep sea \\
\hline 48 & Pacific Canada & & & & & \\
\hline $47-33$ & Pacific USA & & & & & \\
\hline 28 & Baja California & & & & & \\
\hline 12 & El Salvador-Nicaragua & & & & & \\
\hline 35 & Korea \& Japan & & & & & Max \\
\hline $\mathrm{X}$ & S China Sea & & & & & $\mathrm{X}$ \\
\hline 5 & Banda Sea & & & & & \\
\hline 40 & New Zealand & & & & & \\
\hline 18 & Atolls & & & & & \\
\hline & Red Sea/Arabian Gulf & & & & & \\
\hline 10 & Indian Ocean & & & & & \\
\hline 28 & S Africa & & & & & \\
\hline $15-30$ & Australia & & & & & \\
\hline 65 & Antarctic & & & & & \\
\hline
\end{tabular}

Fig. 19. Haplophragmoides bradyi.

Sea and New Zealand (Fig. 21). The marginal marine occurrences parallel those of the marshes but in lower abundance and there is an additional record from the South China Sea. The only shelf occurrence is off the Mississippi delta in the Gulf of Mexico. It is considered to be a generalist with a mode of life ranging from epiphytal on decaying phanerogam leaf debris (Matera \& Lee, 1972; Alve \& Murray, 1999) to infaunal down to $30 \mathrm{~cm}$ (Ozarko et al., 1997). It probably feeds on bacteria and decay products from the leaves. The range of salinity tolerated in marginal marine southern Scandinavia is 10-28 (Alve \& Murray, 1999).

Liebusella goesi. It is known from fjords, where it occurs in marine waters below the halocline (Alve \& Nagy, 1986) and especially on the continental shelf and shelf deeps (Skagerrak, Alve \& Murray, 1997) but its highest abundance is at $405 \mathrm{~m}$ on the slope near Dakar off NW Africa (Lutze, 1980) (Fig. 22).

Miliammina fusca. Extremely euryhaline tolerating salinities of $<1-35$ but there is no correlation between its abundance and salinity (De Rijk, 1995) although Debenay et al. (2002; 2004) found it more abundant in low salinity areas in French Guiana. It is epifaunal to slightly infaunal (Ozarko et al., 1997; Saffert \& Thomas, 1998) but Tobin et al. (2005) found it down to $20 \mathrm{~cm}$ in a Canadian marsh and to $30 \mathrm{~cm}$ in North Carolina, USA. It is epiphytic on filamentous algae on a marsh in southern England (Alve
Haplophragmoides shallow sp.

EAST ATLANTIC
\begin{tabular}{|c|c|c|c|c|c|c|}
\hline$\sim$ lat. N-S & Area & Marsh & Marg mar & Fjords & Shelf & Deep sea \\
\hline & Arctic Ocean & & & & & \\
\hline $70-60$ & N \& W Norway & & & & & \\
\hline 65 & Iceland-Norwegian Sea & & & & & \\
\hline $55-59$ & S Scandinavia/Baltic & & & & & \\
\hline 56 & Seas around UK & & $x$ & & & \\
\hline $43-45$ & Biscay & & & & & \\
\hline 39 & Portugal & Max & & & & \\
\hline 43 & W Mediterranean & & & & & \\
\hline 45 & E Mediterranean & & & & & \\
\hline 20 & NW Africa & & & & & \\
\hline 0 & Gulf of Guinea & & & & & \\
\hline $10-30$ & S Atlantic & & & & & \\
\hline $35-56$ & S Atlantic & & & & & \\
\hline
\end{tabular}
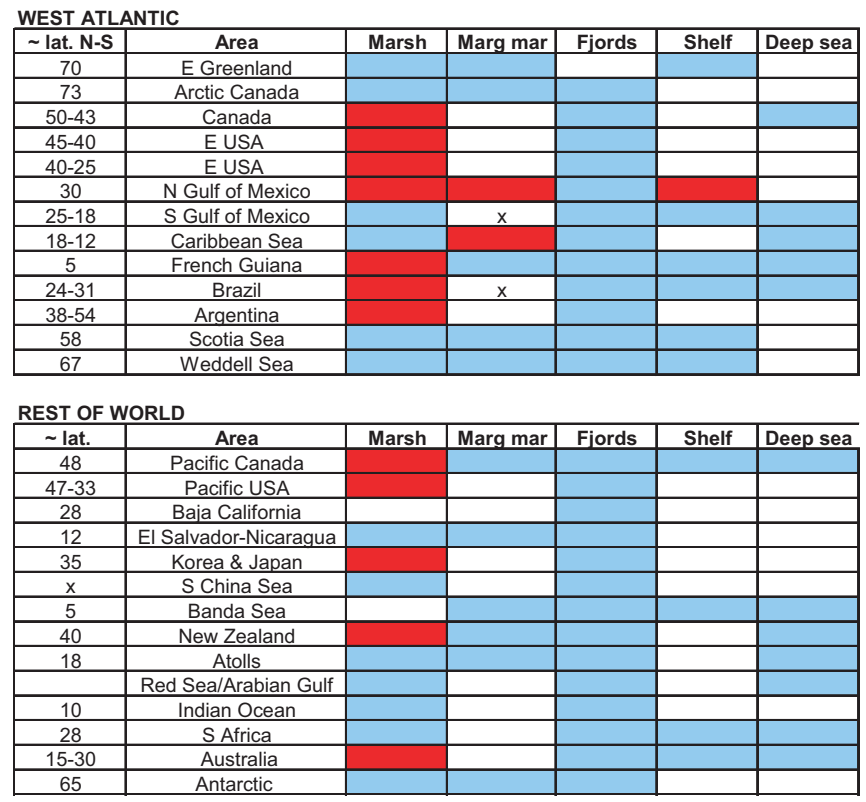

Fig. 20. Haplophragmoides shallow-water spp.

\& Murray, 1999) and in the Baltic it makes up to $50 \%$ of epiphytic assemblages on algae (Wefer, 1976). In an Australian mangal it is infaunal to $40 \mathrm{~cm}$ (Berkeley et al, 2008). This widespread species is found abundantly in marsh and marginal marine and occasionally in fjord and shelf environments in the Atlantic and Pacific oceans (Fig. 23). The upper salinity limit is 25 (Alve, 1995) although the range in marginal marine southern Scandinavia is $10-29$ and the maximum water depth is $2 \mathrm{~m}$ (Alve \& Murray, 1999). Under experimental conditions using material from Georgia, USA, with varying temperature $\left(12\right.$ and $\left.22^{\circ} \mathrm{C}\right)$ and salinity $(12,22,36)$ it grew at all salinities but was most abundant at salinity 12 and it did least well at $12^{\circ} \mathrm{C}$ (Goldstein \& Alve, 2011). However, in Canada this is considered a cool tolerant species (Scott \& Medioli, 1980) so Goldstein \& Alve (2011) suggest that it may be a morphospecies complex of cryptic species with different environmental requirements. The US and Canadian representatives also show genetic differences.

Reophax moniliformis. This species is confined to the NE Atlantic with a rare occurrence in the Mediterranean (Fig. 24). It is mainly present in marginal marine environments but also occurs on marsh, fjord and shelf. It probably feeds on debris from higher plants and green algae (Alve \& Murray, 1999) and the green pigment may indicate either symbiosis with diatoms or their chloroplasts (Knight \& Mantoura, 1985). The optimum temperature may 


EAST ATLANTIC
\begin{tabular}{|c|c|c|c|c|c|c|}
\hline$\sim$ lat. N-S & Area & Marsh & Marg mar & Fjords & Shelf & Deep sea \\
\hline & Arctic Ocean & & & & & \\
\hline $70-60$ & N \& W Norway & & & & & \\
\hline 65 & Iceland-Norwegian Sea & & & & & \\
\hline $55-59$ & S Scandinavia/Baltic & & & X & & \\
\hline 56 & Seas around UK & & & & & \\
\hline $43-45$ & Biscay & & & & & \\
\hline 39 & Portugal & & & & & \\
\hline 43 & W Mediterranean & & & & & \\
\hline 45 & E Mediterranean & & & & & \\
\hline 20 & NW Africa & & & & & \\
\hline 0 & Gulf of Guinea & & & & & \\
\hline $10-30$ & S Atlantic & & & & & \\
\hline $35-56$ & S Atlantic & & & & & \\
\hline
\end{tabular}
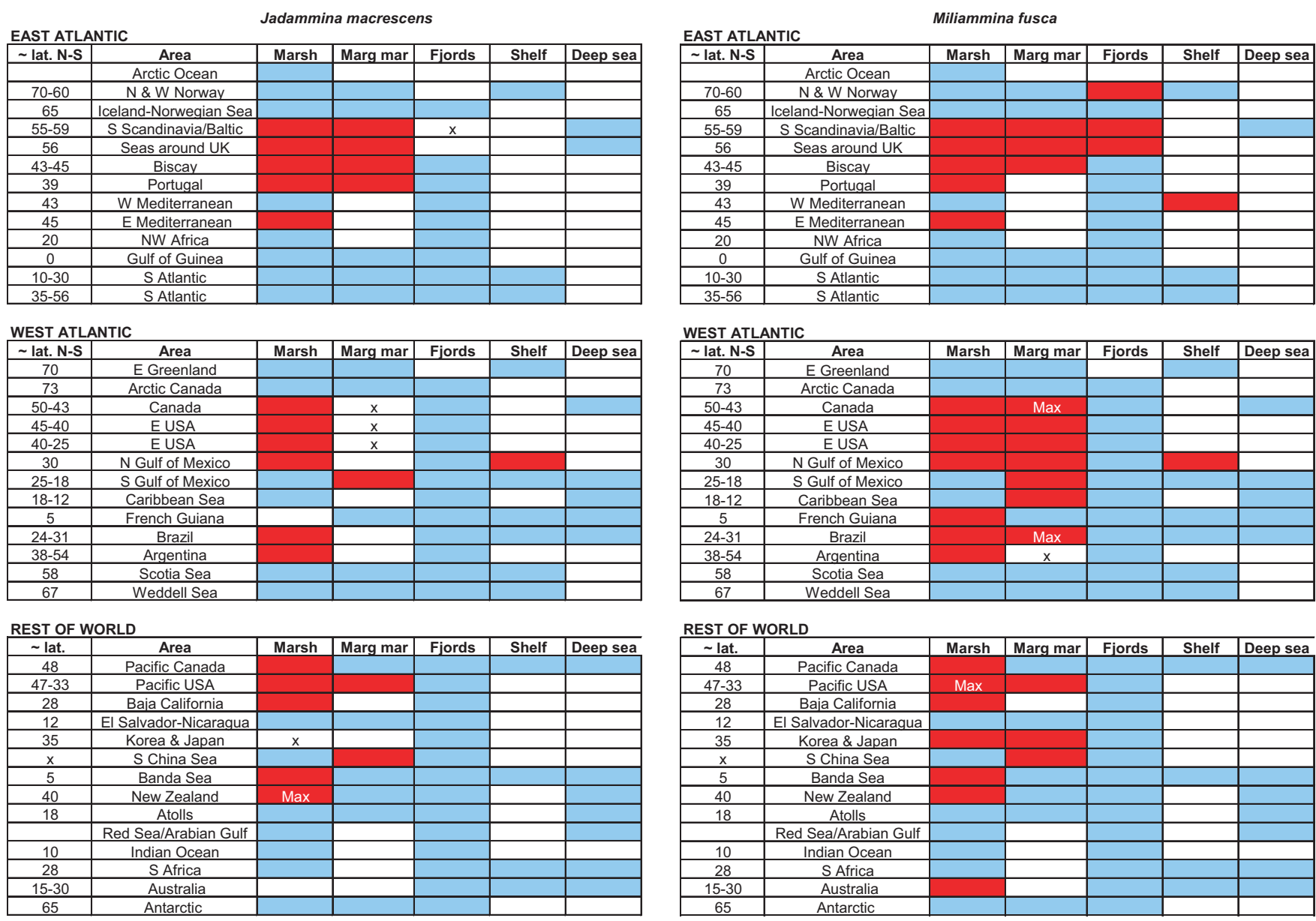

Fig. 21. Jadammina macrescens.
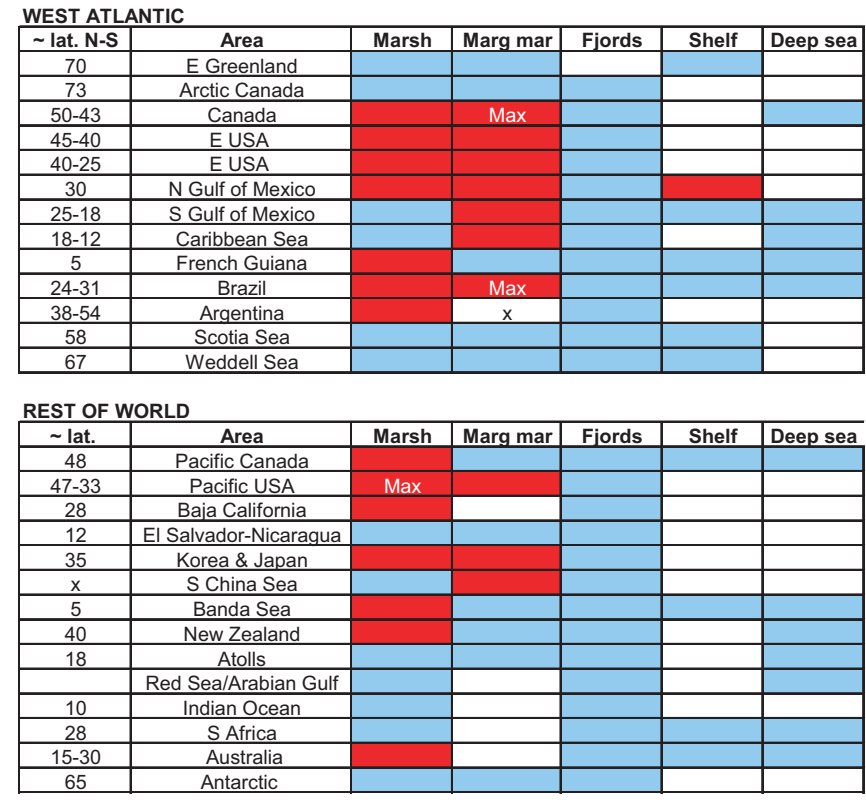

Fig. 23. Miliammina fusca.

Liebusella goesi

EAST ATLANTIC
\begin{tabular}{|c|c|c|c|c|c|c|}
\hline$\sim$ lat. N-S & Area & Marsh & Marg mar & Fjords & Shelf & Bathyal \\
\hline & Arctic Ocean & & & & & \\
\hline $70-60$ & N \& W Norway & & & & & \\
\hline 65 & Iceland-Norwegian Sea & & & & & \\
\hline $55-59$ & S Scandinavia/Baltic & & & & & \\
\hline 56 & Seas around UK & & & & & \\
\hline $43-45$ & Biscay & & & & & \\
\hline 39 & Portugal & & & & & \\
\hline 43 & W Mediterranean & & & & & \\
\hline 45 & E Mediterranean & & & & & \\
\hline 20 & NW Africa & & & & & Max \\
\hline 0 & Gulf of Guinea & & & & & \\
\hline $10-30$ & S Atlantic & & & & & \\
\hline $35-56$ & S Atlantic & & & & & \\
\hline
\end{tabular}

Fig. 22. Liebusella goesi.

be $15-20^{\circ} \mathrm{C}$ (Murray, 1968). The range of salinity tolerated in marginal marine southern Scandinavia is 15-28 (Alve \& Murray, 1999).

Reophax nana. The type specimens come from the mouth of the Para River, Brazil. It has inflated chambers so the periphery is lobulate rather than smooth as in $R$. moniliformis.

By contrast with the latter, $R$. nana is common in the West Atlantic (sometimes on marsh/mangal but typically marginal marine) from Canada to Brazil (Fig. 25) and likewise along the Pacific seaboard of North America and with 4 records from South Africa in the Indian Ocean. On the eastern side of the Atlantic it is rare in marshes in northern Spain and present on the shelf in Biscay and off the Ebro in the Mediterranean. In the Adriatic it is restricted to the top $4 \mathrm{~cm}$ (Barmawidjaja et al., 1992).

Siphotrochammina lobata. This primarily marsh/mangal species is found from North Carolina, USA, to French Guiana with marginal marine occurrences in Tobago and Brazil (Fig. 26). It is epiphytic on mangrove tree roots in Brazil (Eichler et al., 1995; Debenay et al., 1996) yet rare in French Guiana (Debenay et al., 2002).

Textularia earlandi. Sometimes recorded as T. tenuissima, this species is widespread (Arctic, Atlantic, Pacific, Indian, Southern oceans) and occurs in marsh/mangal, marginal marine, fjord, shelf and deep-sea environments (Fig. 27). In a two-year experiment, where the fauna was deprived of fresh phytodetritus, it increased in abundance, perhaps indicating a need for fresh food (Alve, 2010). In experiments using sediment collected from $320 \mathrm{~m}$ water depth in the Skagerrak aliquots were stored for 2 years in a cold room at the original ambient temperature of $5^{\circ} \mathrm{C}$ and then exposed to shallow-water conditions for 11 months; this was the only species that continued to flourish. The authors attributed this to its opportunistic lifestyle (Alve \& Goldstein, 2010).

Tiphotrocha comprimata. A marsh species found only in the Atlantic from southern Scandinavia to Portugal and from Canada 
Reophax moniliformis

EAST ATLANTIC
\begin{tabular}{|c|c|c|c|c|c|c|}
\hline$\sim$ lat. N-S & Area & Marsh & Marg mar & Fjords & Shelf & Deep sea \\
\hline & Arctic Ocean & & & & & \\
\hline $70-60$ & N \& W Norway & & & & & \\
\hline 65 & Iceland-Norwegian Sea & & & & & \\
\hline $55-59$ & S Scandinavia/Baltic & & Max & & & \\
\hline 56 & Seas around UK & & & & & \\
\hline $43-45$ & Biscay & & & & & \\
\hline 39 & Portugal & & & & & \\
\hline 43 & W Mediterranean & & & & & \\
\hline 45 & E Mediterranean & & & & X & \\
\hline 20 & NW Africa & & & & & \\
\hline 0 & Gulf of Guinea & & & & & \\
\hline $10-30$ & S Atlantic & & & & & \\
\hline $35-56$ & S Atlantic & & & & & \\
\hline
\end{tabular}

Fig. 24. Reophax moniliformis.

Reophax nana
\begin{tabular}{|c|c|c|c|c|c|c|}
\hline$\sim$ lat. N-S & Area & Marsh & Marg mar & Fjords & Shelf & Deep sea \\
\hline & Arctic Ocean & & & & & \\
\hline $70-60$ & N \& W Norway & & & & & \\
\hline 65 & Iceland-Norwegian Sea & & & & & \\
\hline $55-59$ & S Scandinavia/Baltic & & & & & \\
\hline 56 & Seas around UK & & & & & \\
\hline $43-45$ & Biscay & & $x$ & & & \\
\hline 39 & Portugal & & & & & \\
\hline 43 & W Mediterranean & & & & & \\
\hline 45 & E Mediterranean & & & & & \\
\hline 20 & NW Africa & & & & & \\
\hline 0 & Gulf of Guinea & & & & & \\
\hline $10-30$ & S Atlantic & & & & & \\
\hline $35-56$ & S Atlantic & & & & & \\
\hline
\end{tabular}

WEST ATLANTIC
\begin{tabular}{|c|c|c|c|c|c|c|}
\hline$\sim$ lat. N-S & Area & Marsh & Marg mar & Fjords & Shelf & Deep sea \\
\hline 70 & E Greenland & & & & & \\
\hline 73 & Arctic Canada & & & & & \\
\hline $50-43$ & Canada & & & & & \\
\hline $45-40$ & E USA & & & & & \\
\hline $40-25$ & E USA & & & & & \\
\hline 30 & N Gulf of Mexico & & & & & \\
\hline $25-18$ & S Gulf of Mexico & & & & & \\
\hline $18-12$ & Caribbean Sea & & & & & \\
\hline 5 & French Guiana & & & & & \\
\hline $24-31$ & Brazil & & & & & \\
\hline $38-54$ & Argentina & & & & & \\
\hline 58 & Scotia Sea & & & & & \\
\hline 67 & Weddell Sea & & & & & \\
\hline
\end{tabular}

REST OF WORLD
\begin{tabular}{|c|c|c|c|c|c|c|}
\hline$\sim$ lat. & Area & Marsh & Marg mar & Fjords & Shelf & Deep sea \\
\hline 48 & Pacific Canada & & & & & \\
\hline $47-33$ & Pacific USA & & Max & & & \\
\hline 28 & Baja California & & & & & \\
\hline 12 & El Salvador-Nicaragua & & & & & \\
\hline 35 & Korea \& Japan & & & & & \\
\hline X & S China Sea & & & & & \\
\hline 5 & Banda Sea & & & & & \\
\hline 40 & New Zealand & & & & & \\
\hline 18 & Atolls & & & & & \\
\hline & Red Sea/Arabian Gulf & & & & & \\
\hline 10 & Indian Ocean & & & & & \\
\hline 28 & S Africa & & & & & \\
\hline $15-30$ & Australia & & & & & \\
\hline 65 & Antarctic & & & & & \\
\hline
\end{tabular}

Fig. 25. Reophax nana.

WEST ATLANTIC
\begin{tabular}{|c|c|c|c|c|c|c|}
\hline$\sim$ lat. N-S & Area & Marsh & Marg mar & Fjords & Shelf & Deep sea \\
\hline 70 & E Greenland & & & & & \\
\hline 73 & Arctic Canada & & & & & \\
\hline $50-43$ & Canada & & & & & \\
\hline $45-40$ & E USA & & & & & \\
\hline $40-25$ & E USA & Max & & & & \\
\hline 30 & N Gulf of Mexico & & & & & \\
\hline $25-18$ & S Gulf of Mexico & & & & & \\
\hline $18-12$ & Caribbean Sea & & & & & \\
\hline 5 & French Guiana & & & & & \\
\hline $24-31$ & Brazil & & & & & \\
\hline $38-54$ & Argentina & & & & & \\
\hline 58 & Scotia Sea & & & & & \\
\hline 67 & Weddell Sea & & & & & \\
\hline
\end{tabular}

Fig. 26. Siphotrochammina lobata.
Textularia earlandi
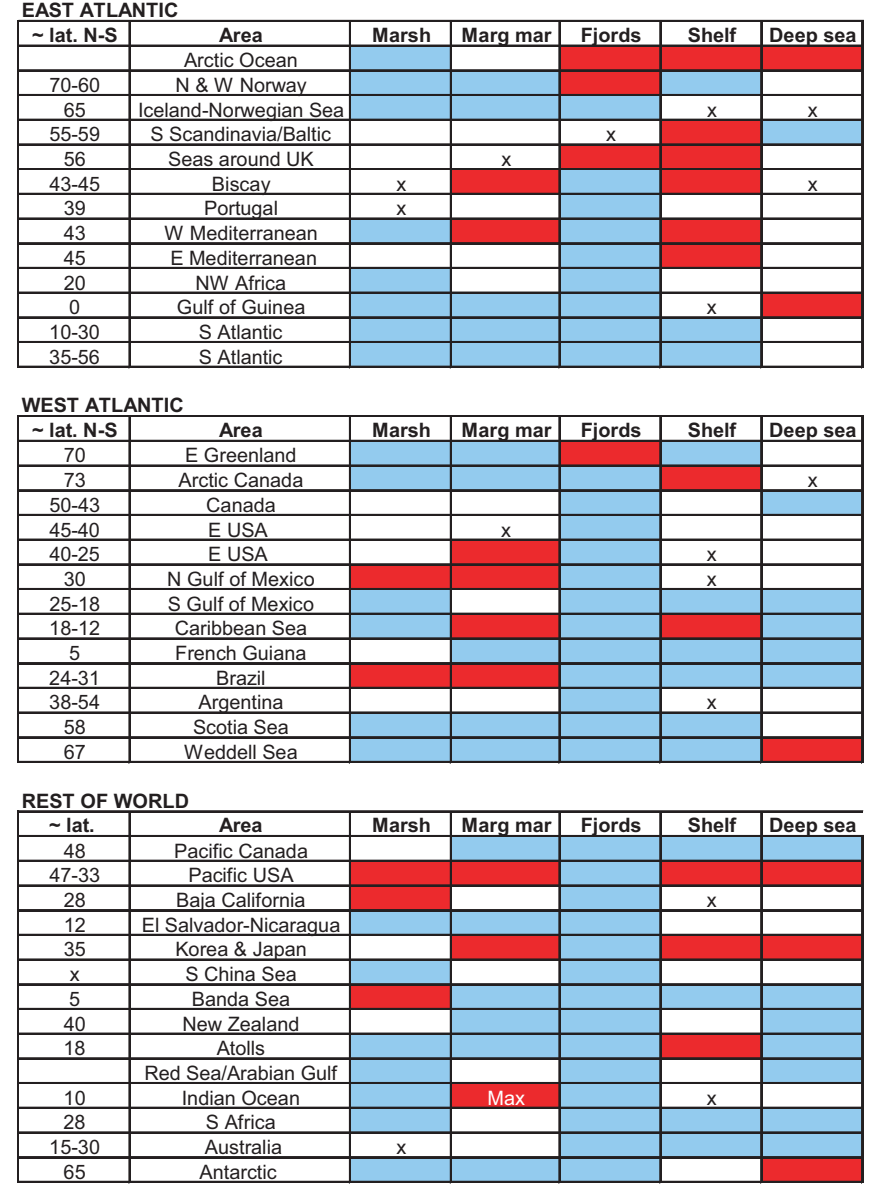

Fig. 27. Textularia earlandi.

to Brazil, with a few occurrences in marginal marine environments (Fig. 28). It is epifaunal, free or clinging to algae or infaunal down to $20 \mathrm{~cm}$ (Saffert \& Thomas, 1998) and a herbivore or detritivore. The range of salinity tolerated in marginal marine southern Scandinavia is 20-28 (Alve \& Murray, 1999).

Trochammina inflata. This is the typical marsh species widely distributed throughout the Atlantic and Pacific oceans but it also occurs in marginal marine settings including in the Indian Ocean. There are single records on the shelf off Japan and the Mississippi delta and 8 occurrences in the Adriatic Sea (Fig. 29). Although found in small numbers in epiphytic communities (Matera \& Lee, 1972), it is most commonly found living infaunally (e.g. Steineck \& Bergstein, 1979; Langer et al., 1989; Goldstein \& Harben, 1993; Ozarko et al., 1997; Saffert \& Thomas, 1998; Berkeley et al., 2008). It is a herbivore or detritivore feeding on bacteria (Matera \& Lee, 1972). The range of salinity tolerated in marginal marine southern Scandinavia is 10-28 (Alve \& Murray, 1999). Some records of dead T. inflata from the deep sea may be misidentifications of T. subturbinatus (see Murray \& Alve, 2011).

Trochammina lobata. There are only 21 records of this species, from the Scotian shelf, Canada, to North Carolina, USA, with a single occurrence on the slope at $850 \mathrm{~m}$ off the latter. 
Tiphotrocha comprimata

EAST ATLANTIC
\begin{tabular}{|c|c|c|c|c|c|c|}
\hline$\sim$ lat. N-S & Area & Marsh & Marg mar & Fjords & Shelf & Deep sea \\
\hline & Arctic Ocean & & & & & \\
\hline $70-60$ & N \& W Norway & & & & & \\
\hline 65 & Iceland-Norwegian Sea & & & & & \\
\hline $55-59$ & S Scandinavia/Baltic & & & & & \\
\hline 56 & Seas around UK & & & & & \\
\hline $43-45$ & Biscay & & & & & \\
\hline 39 & Portugal & & & & & \\
\hline 43 & W Mediterranean & & & & & \\
\hline 45 & E Mediterranean & & & & & \\
\hline 20 & NW Africa & & & & & \\
\hline 0 & Gulf of Guinea & & & & & \\
\hline $10-30$ & S Atlantic & & & & & \\
\hline $35-56$ & S Atlantic & & & & & \\
\hline
\end{tabular}

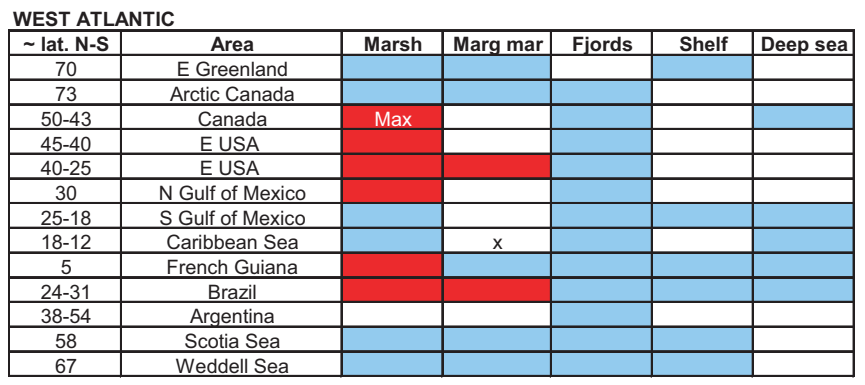

Fig. 28. Tiphotrocha comprimata.

Trochammina inflata

EAST ATLANTIC
\begin{tabular}{|c|c|c|c|c|c|c|}
\hline$\sim$ lat. N-S & Area & Marsh & Marg mar & Fjords & Shelf & Deep sea \\
\hline & Arctic Ocean & & & & & \\
\hline $70-60$ & N \& W Norway & & & & & \\
\hline 65 & Iceland-Norwegian Sea & & & & & \\
\hline $55-59$ & S Scandinavia/Baltic & & & & & \\
\hline 56 & Seas around UK & & & & & \\
\hline $43-45$ & Biscay & & & & & \\
\hline 39 & Portugal & & & & & \\
\hline 43 & W Mediterranean & & & & & \\
\hline 45 & E Mediterranean & & & & & \\
\hline 20 & NW Africa & & & & & \\
\hline 0 & Gulf of Guinea & & & & & \\
\hline $10-30$ & S Atlantic & & & & & \\
\hline $35-56$ & S Atlantic & & & & & \\
\hline
\end{tabular}
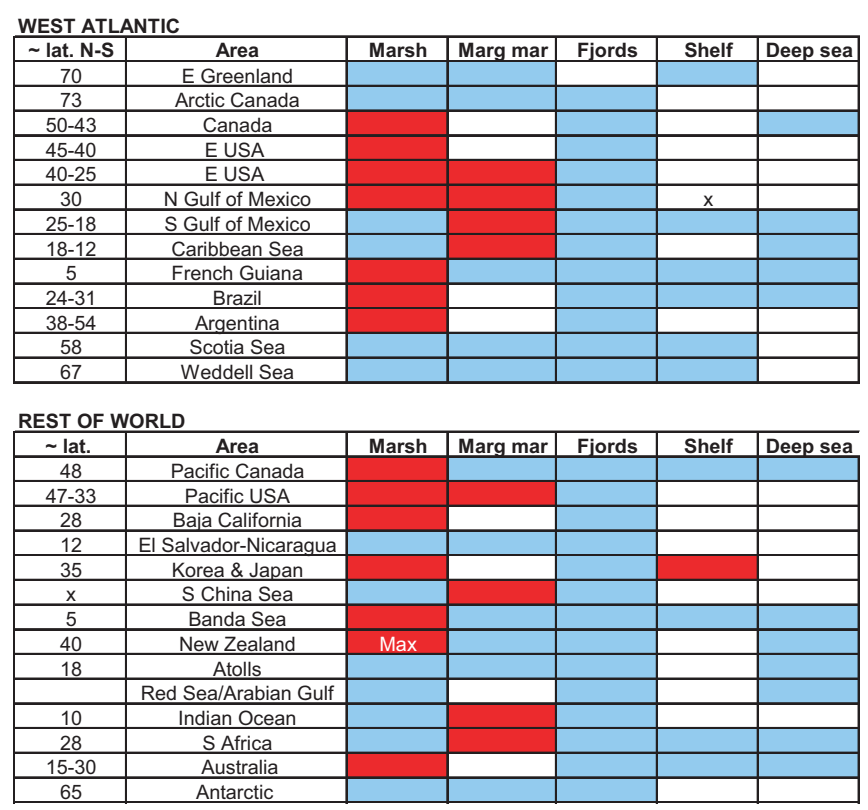

Fig. 29. Trochammina inflata.

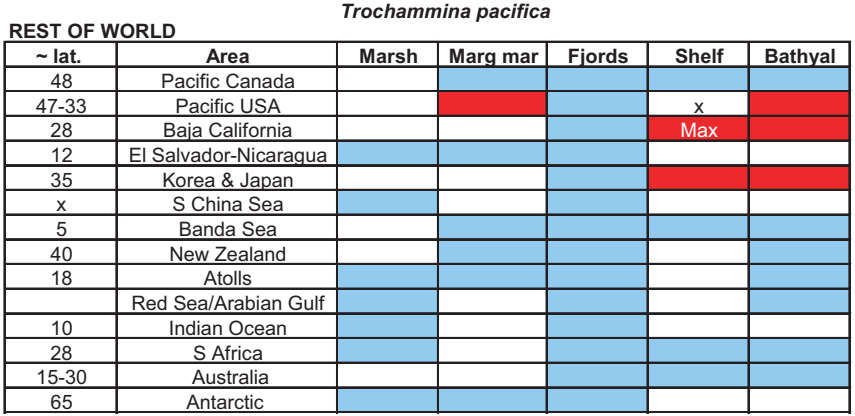

Fig. 30. Trochammina pacifica
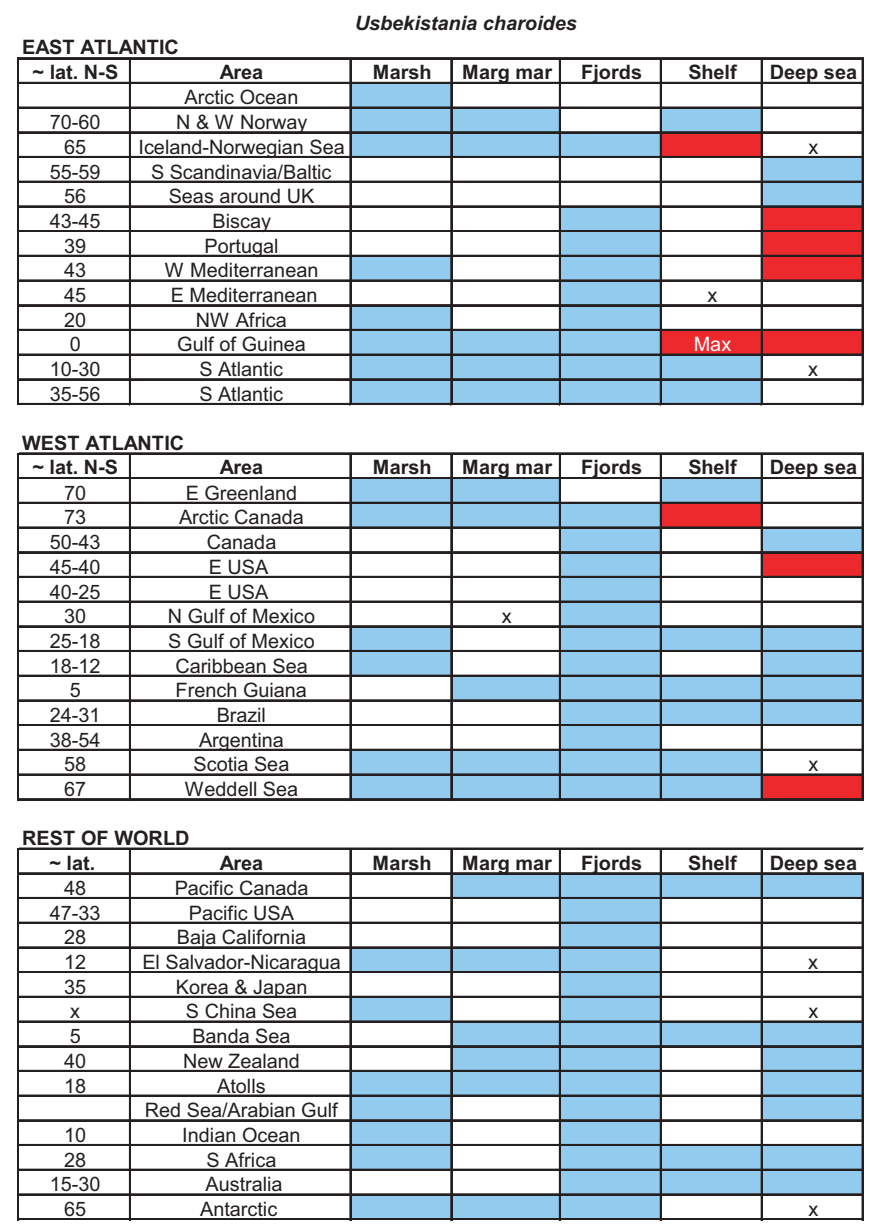

Fig. 31. Usbekistania charoides.

Trochammina pacifica. As the name suggests this is a Pacific species with occurrences in marginal marine, shelf and deep sea along the margin of North America and off Japan (Fig. 30).

Usbekistania charoides. With the exception of records from a lagoon in the Gulf of Mexico (which may be a misidentification), all occurrences are from shelf or deep sea, in the Atlantic and Pacific oceans and the South China Sea. The maximum abundance is on the shelf in the Gulf of Guinea (Fig. 31). In the Gulf of Cadiz the lower and upper limits in the sediment correspond with low and high oxygen so this species is not an indicator of low oxygen conditions (Schönfeld, 2001). 
Porcelaneous taxa

Cornuspira involvens/planorbis. Only a few species of Cornuspira have been described and the two most commonly recorded in modern sediments are $C$. involvens, based on material from the Tertiary of the Vienna basin, Austria (although d'Orbigny, 1839 also mentioned records from recent sediments off Cuba and Martinique) and C. planorbis, from Recent mud off Mozambique. The holotype of $C$. involvens is $1-2 \mathrm{~mm}$ in diameter while the type form illustrated for $C$. planorbis is a juvenile. The former seems to be microspheric and the latter megalospheric. There is taxonomic confusion surrounding these species because different workers have different views on morphological variability. Phleger \& Parker (1951) noted that because of this, recorded distributions may be inaccurate. However, in view of the features of the types, it seems highly probable that $C$. involvens and C. planorbis are one species (discussion with Elisabeth Alve, 2011) and are treated so here.

Cornuspira involvens/planorbis is widely distributed throughout the world's oceans, from marshes to bathyal (Fig. 32), in normal marine salinities but highly variable temperatures. Typically it ranges from zero to low abundance (rarely above 6-7\%). However, there are occasional high abundances (up to $55 \%$ ) which are almost certainly reproductive blooms coincident with the time of sampling. Such blooms are known from marginal

Cornuspira involvens
\begin{tabular}{|c|c|c|c|c|c|c|}
\hline$\sim$ lat. N-S & Area & Marsh & Marg mar & Fjords & Shelf & Deep sea \\
\hline & Arctic Ocean & & & & & \\
\hline $70-60$ & N \& W Norway & & & & & $\mathrm{X}$ \\
\hline 65 & Iceland-Norwegian Sea & & & & & \\
\hline $55-59$ & S Scandinavia/Baltic & & & & & \\
\hline 56 & Seas around UK & & $x$ & & & \\
\hline $43-45$ & Biscay & & & & & \\
\hline 39 & Portugal & & & & & \\
\hline 43 & W Mediterranean & & & & & $x$ \\
\hline 45 & E Mediterranean & & & & & \\
\hline 20 & NW Africa & & & & & \\
\hline 0 & Gulf of Guinea & & & & & $\mathrm{x}$ \\
\hline $10-30$ & S Atlantic & & & & & $\mathrm{x}$ \\
\hline $35-56$ & S Atlantic & & & & & \\
\hline
\end{tabular}

WEST ATLANTIC
\begin{tabular}{|c|c|c|c|c|c|c|}
\hline$\sim$ lat. N-S & Area & Marsh & Marg mar & Fjords & Shelf & Deep sea \\
\hline 70 & E Greenland & & & & & X \\
\hline 73 & Arctic Canada & & & & & \\
\hline $50-43$ & Canada & & & & & \\
\hline $45-40$ & E USA & & $x$ & & & \\
\hline $40-25$ & E USA & & & & & \\
\hline 30 & N Gulf of Mexico & & & & & \\
\hline $25-18$ & S Gulf of Mexico & & & & & \\
\hline $18-12$ & Caribbean Sea & & & & & \\
\hline 5 & French Guiana & & & & & \\
\hline $24-31$ & Brazil & & & & & \\
\hline $38-54$ & Argentina & & & & & \\
\hline 58 & Scotia Sea & & & & & \\
\hline 67 & Weddell Sea & & & & & $x$ \\
\hline
\end{tabular}

REST OF WORLD
\begin{tabular}{|c|c|c|c|c|c|c|}
\hline$\sim$ lat. & Area & Marsh & Marg mar & Fjords & Shelf & Deep sea \\
\hline 48 & Pacific Canada & & & & & \\
\hline $47-33$ & Pacific USA & & & & & \\
\hline 28 & Baja California & & & & & \\
\hline 12 & El Salvador-Nicaragua & & & & X & \\
\hline 35 & Korea \& Japan & & & & & \\
\hline $\mathrm{x}$ & S China Sea & & & & & \\
\hline 5 & Banda Sea & & & & & \\
\hline 40 & New Zealand & Max & & & & \\
\hline 18 & Atolls & & & & & \\
\hline & Red Sea/Arabian Gulf & & & & & \\
\hline 10 & Indian Ocean & & & & & \\
\hline 28 & S Africa & & & & & \\
\hline $15-30$ & Australia & & & & & \\
\hline 65 & Antarctic & & & & & \\
\hline
\end{tabular}

Fig. 32. Cornuspira involvens.
Pyrgo williamsoni

EAST ATLANTIC
\begin{tabular}{|c|c|c|c|c|c|c|}
\hline$\sim$ lat. N-S & Area & Marsh & Marg mar & Fjords & Shelf & Deep sea \\
\hline & Arctic Ocean & & $\mathrm{x}$ & & $\mathrm{x}$ & \\
\hline $70-60$ & N \& W Norway & & & $\mathrm{x}$ & & \\
\hline 65 & Iceland-Norwegian Sea & & & & & $\mathrm{x}$ \\
\hline $55-59$ & S Scandinavia/Baltic & & & $\mathrm{x}$ & & \\
\hline 56 & Seas around UK & & & & Max & \\
\hline $43-45$ & Biscay & & & & & \\
\hline 39 & Portugal & & & & & \\
\hline 43 & W Mediterranean & & & & & \\
\hline 45 & E Mediterranean & & & & & \\
\hline 20 & NW Africa & & & & & \\
\hline 0 & Gulf of Guinea & & & & & \\
\hline $10-30$ & S Atlantic & & & & & \\
\hline $35-56$ & S Atlantic & & & & & \\
\hline
\end{tabular}

Fig. 33. Pyrgo williamsoni.

\begin{tabular}{|c|c|c|c|c|c|c|}
\hline \multicolumn{7}{|c|}{ Amphicoryna spp. } \\
\hline$\sim$ lat. N-S & Area & Marsh & Marg mar & Fiords & Shelf & Deep sea \\
\hline & Arctic Ocean & & & & & \\
\hline $70-60$ & N \& W Norway & & & & & \\
\hline 65 & Iceland-Norwegian Sea & & & & & \\
\hline $55-59$ & S Scandinavia/Baltic & & & & & \\
\hline 56 & Seas around UK & & & & & \\
\hline $43-45$ & Biscay & & & & $x$ & \\
\hline 39 & Portugal & & & & & \\
\hline 43 & W Mediterranean & & & & $\operatorname{Max}$ & \\
\hline 45 & E Mediterranean & & & & $x$ & \\
\hline 20 & NW Africa & & & & & \\
\hline 0 & Gulf of Guinea & & & & & $x$ \\
\hline $10-30$ & S Atlantic & & & & & \\
\hline $35-56$ & S Atlantic & & & & & \\
\hline
\end{tabular}

REST OF WORLD

\begin{tabular}{|c|c|c|c|c|c|c|}
\hline$\sim$ lat. & Area & Marsh & Marg mar & Fjords & Shelf & Deep sea \\
\hline 48 & Pacific Canada & & & & & \\
\hline $47-33$ & Pacific USA & & & & & \\
\hline 28 & Baja California & & & & & \\
\hline 12 & El Salvador-Nicaragua & & & & & \\
\hline 35 & Korea \& Japan & & & & & \\
\hline $\mathrm{X}$ & S China Sea & & & & & \\
\hline 5 & Banda Sea & & & & & \\
\hline 40 & New Zealand & & & & & \\
\hline 18 & Atolls & & & & & \\
\hline & Red Sea/Arabian Gulf & & & & & \\
\hline 10 & Indian Ocean & & & & & \\
\hline 28 & S Africa & & & & & \\
\hline $15-30$ & Australia & & & & & \\
\hline 65 & Antarctic & & & & & \\
\hline
\end{tabular}

Fig. 34. Amphicoryna spp.

marine (northern Spain, summer; Barbuda, autumn), fjord (Svalbard and southern Norway, summer), continental shelf (Scotland, summer) and deep sea. It is epiphytic off Western Australia (Semeniuk, 2001).

Pyrgo williamsoni. Confined to the Arctic Ocean and the NW European seaboard in fjords, shelf and deep sea (Fig. 33) with maximum abundance on the shelf. In the Arctic Ocean it occurs in seasonally ice-free areas and also beneath permanent ice cover (Wollenburg \& Mackensen, 1998).

\section{Hyaline taxa}

Amphicoryna. This genus is present (mainly as A. scalaris) in low abundance in shelf and deep-sea settings in the eastern North and tropical Atlantic Ocean and in the Mediterranean (Fig. 34). It appears to be absent from the South Atlantic. There are a few records from the deep sea in the South China Sea. It occurs where the mean sea floor organic C flux is $\sim 40 \mathrm{~g} \mathrm{~m}^{2} \mathrm{a}^{-1}$ (Altenbach et al., 1999). The range tolerated in the Gulf of Guinea is $7.4-124.2 \mathrm{gm}^{2} \mathrm{a}^{-1}$ (Altenbach et al., 2003).

Astacolus. Three species have living representatives (A. crepidulus, A. hyalacrulus, $A$. insolitus) and other references are recorded 
EAST ATLANTIC

\begin{tabular}{|c|c|c|c|c|c|c|}
\hline$\sim$ lat. N-S & Area & Marsh & Marg mar & Fjords & Shelf & Deep sea \\
\hline & Arctic Ocean & & & $\mathrm{x}$ & & \\
\hline $70-60$ & N \& W Norway & & & $\mathrm{x}$ & & \\
\hline 65 & Iceland-Norwegian Sea & & & & & \\
\hline $55-59$ & S Scandinavia/Baltic & & & & & \\
\hline 56 & Seas around UK & & & & & \\
\hline $43-45$ & Biscay & & & & & \\
\hline 39 & Portugal & & & & & \\
\hline 43 & W Mediterranean & & & & $x$ & \\
\hline 45 & E Mediterranean & & & & $x$ & \\
\hline 20 & NW Africa & & & & & X \\
\hline 0 & Gulf of Guinea & & & & & \\
\hline $10-30$ & S Atlantic & & & & & \\
\hline $35-56$ & S Atlantic & & & & & \\
\hline
\end{tabular}

\section{WEST ATLANTIC}

\begin{tabular}{|c|c|l|l|l|l|l|}
\hline$\sim$ lat. N-S & Area & Marsh & Marg mar & Fjords & Shelf & Deep sea \\
\hline 70 & E Greenland & & & & & \\
\hline 73 & Arctic Canada & & & & & \\
\hline $50-43$ & Canada & & & & & \\
\hline $45-40$ & E USA & & & & & \\
\hline $40-25$ & E USA & & & & & \\
\hline 30 & N Gulf of Mexico & & & & & \\
\hline $25-18$ & S Gulf of Mexico & & & & & \\
\hline $18-12$ & Caribbean Sea & & & & & \\
\hline 5 & French Guiana & & & & & \\
\hline $24-31$ & Brazil & & & & & \\
\hline $38-54$ & Argentina & & & & & \\
\hline 58 & Scotia Sea & & & & & \\
\hline 67 & Weddell Sea & & & & & \\
\hline
\end{tabular}

Fig. 35. Astacolus spp..

as sp.. The genus occurs only in the Atlantic Ocean in fjords, shelf seas and deep sea but only in the latter two does the mean exceed $1 \%$ and the maximum abundance is $4.2 \%$ in a Norwegian fjord. It occurs down to $4495 \mathrm{~m}$ in the Scotia Sea (Fig. 35).

Asterigerina carinata. This low latitude, warm-water species is confined to marginal marine in the Caribbean Sea and shelf in southern USA and Nicaragua (Fig. 36).

Asterigerinata mamilla. Most records are from the NE Atlantic and Mediterranean in marginal marine and shelf environments but the author also recorded it on the shelf off the USA (Fig. 37) and at $1002 \mathrm{~m}$ off the UK. It is epifaunal clinging to larger detrital fragments (Sturrock \& Murray, 1981) or on submarine vegetation (Murray, 2006, p. 131).

Astrononion. Several species are known and four (echolsi, gallowayi, sidebottomi and stelligerum) are discussed below. These four species have a laterally compressed test, 8-10 chambers in the final whorl, and supplementary chamberlets arranged around the umbilici, distinct in all but $A$. echolsi. The types are from Recent sediments with $A$. echolsi and $A$. gallowayi from high latitudes and $A$. sidebottomi and A. stelligera from mid latitudes. Records for named species and including those left in open nomenclature show a distribution from marginal marine to deep sea in the Atlantic and Pacific oceans (Fig. 38) but the genus is typically present in shelf and deep sea.

Astrononion echolsi. The distinctive features are the compressed test with short, somewhat indistinct supplementary chambers with forward slanting apertures. It was described from the Ross Sea, Antarctica. There are no records of stained material from there but it occurs in the Scotia and Weddell seas as well as in the South Atlantic (Fig. 39).

Astrononion gallowayi. This is the most widely distributed species in fjords from Arctic Russia and Scandinavia, shelf seas from the
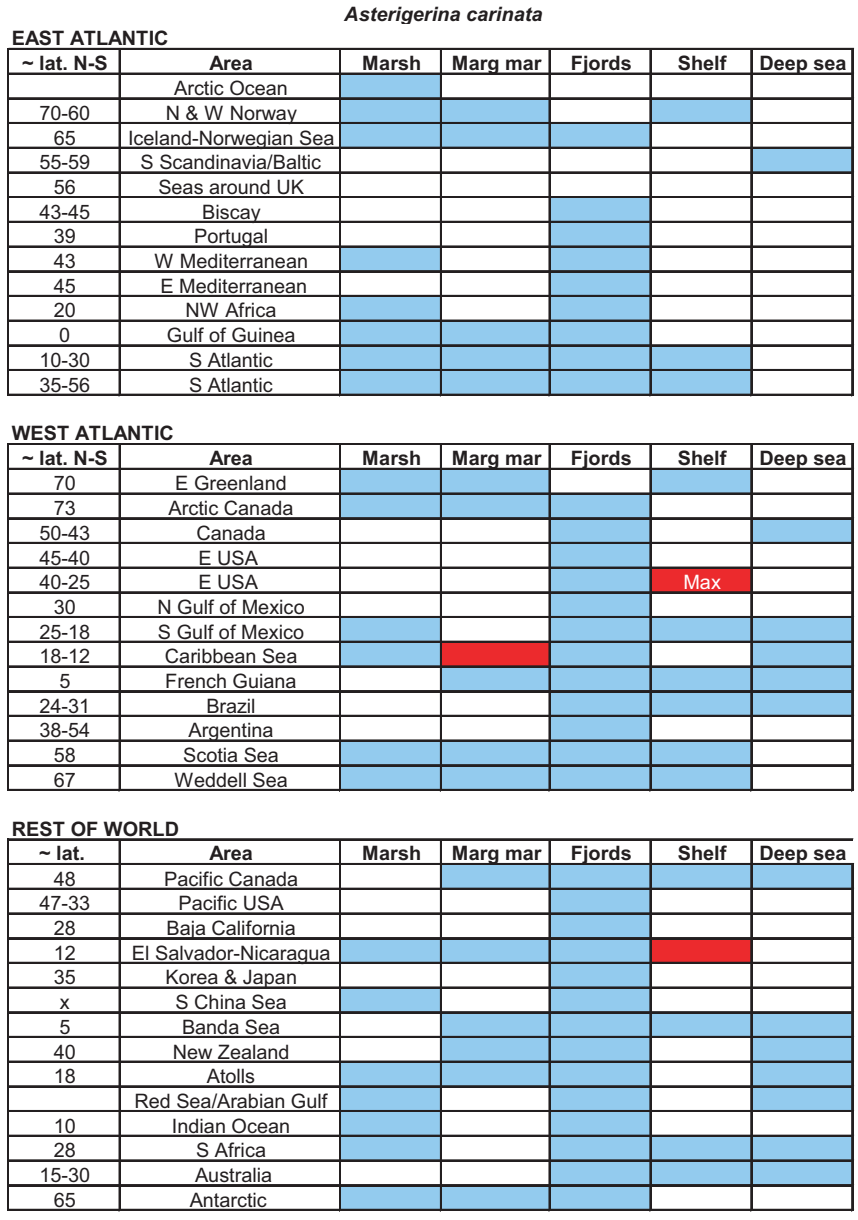

Fig. 36. Asterigerina carinata.

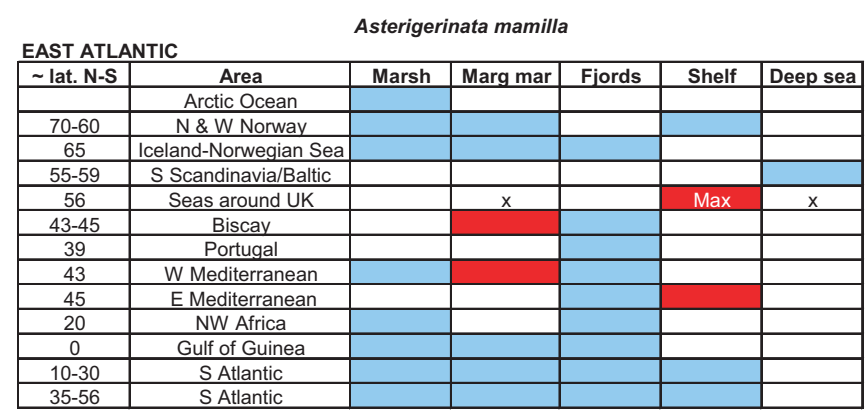

WEST ATLANTIC

WEST ATLANTIC
\begin{tabular}{|c|c|c|c|c|c|c|}
\hline$\sim$ lat. N-S & Area & Marsh & Marg mar & Fjords & Shelf & Deep sea \\
\hline 70 & E Greenland & & & & & \\
\hline 73 & Arctic Canada & & & & & \\
\hline $50-43$ & Canada & & & & & \\
\hline $45-40$ & E USA & & & & & \\
\hline $40-25$ & E USA & & & & & \\
\hline 30 & N Gulf of Mexico & & & & & \\
\hline $25-18$ & S Gulf of Mexico & & & & & \\
\hline $18-12$ & Caribbean Sea & & & & & \\
\hline 5 & French Guiana & & & & & \\
\hline $24-31$ & Brazil & & & & & \\
\hline $38-54$ & Argentina & & & & & \\
\hline 58 & Scotia Sea & & & & & \\
\hline 67 & Weddell Sea & & & & & \\
\hline
\end{tabular}

Fig. 37. Asterigerinata mamilla. 
Astrononion all spp.
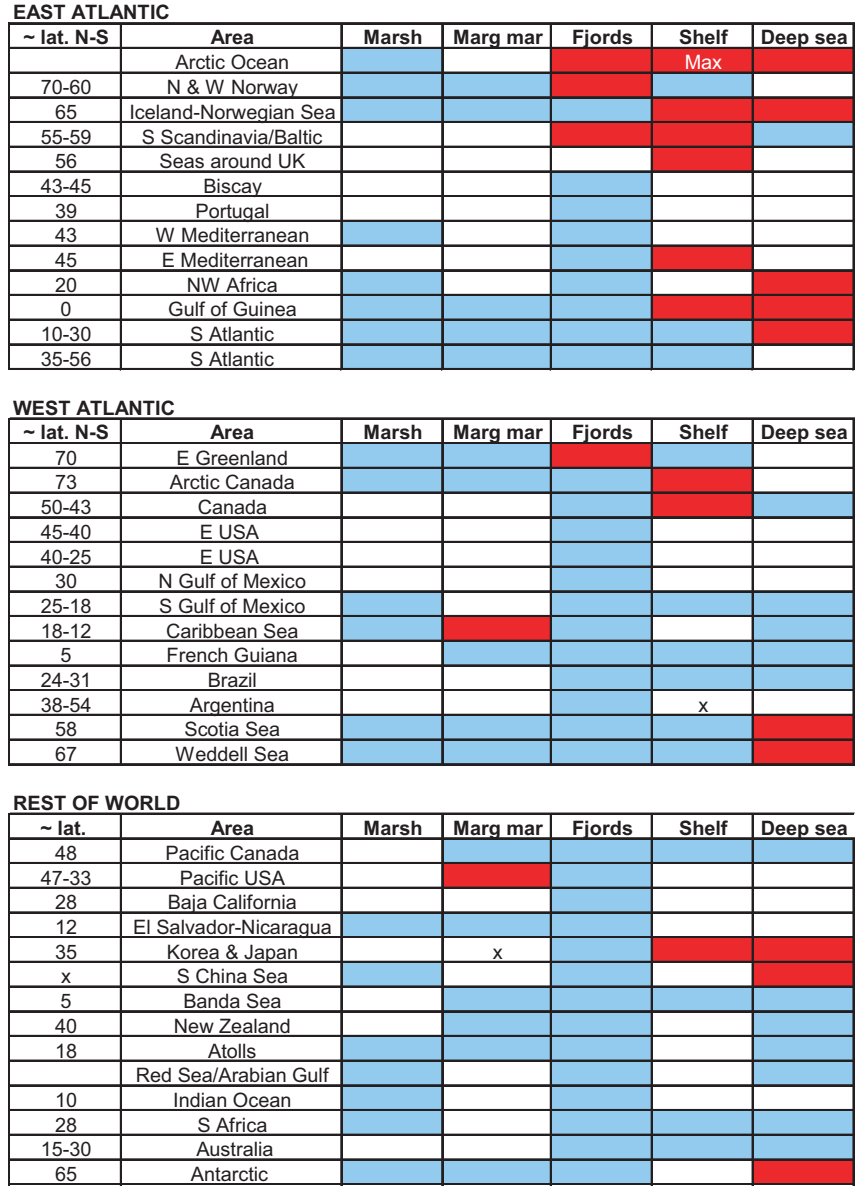

Fig. 38. Astrononion spp.

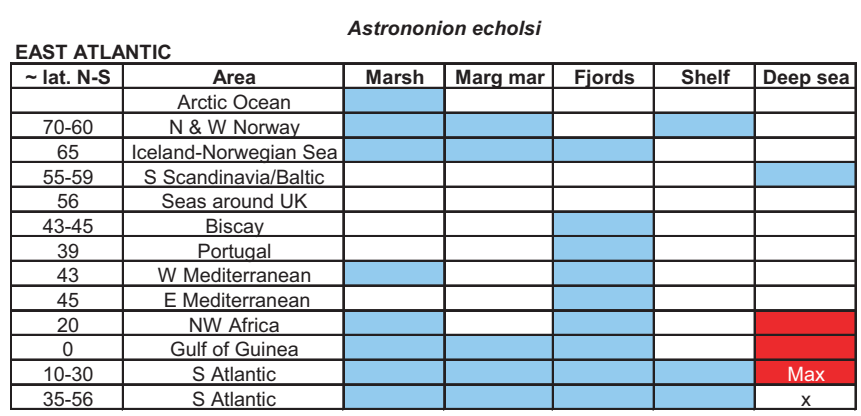

WEST ATLANTIC
\begin{tabular}{|c|c|c|c|c|c|c|}
\hline$\sim$ lat. N-S & Area & Marsh & Marg mar & Fjords & Shelf & Deep sea \\
\hline 70 & E Greenland & & & & & \\
\hline 73 & Arctic Canada & & & & & \\
\hline $50-43$ & Canada & & & & & \\
\hline $45-40$ & E USA & & & & & \\
\hline $40-25$ & E USA & & & & & \\
\hline 30 & N Gulf of Mexico & & & & & \\
\hline $25-18$ & S Gulf of Mexico & & & & & \\
\hline $18-12$ & Caribbean Sea & & & & & \\
\hline 5 & French Guiana & & & & & \\
\hline $24-31$ & Brazil & & & & & \\
\hline $38-54$ & Argentina & & & & & \\
\hline 58 & Scotia Sea & & & & & \\
\hline 67 & Weddell Sea & & & & & \\
\hline
\end{tabular}

Fig. 39. Astrononion echolsi.
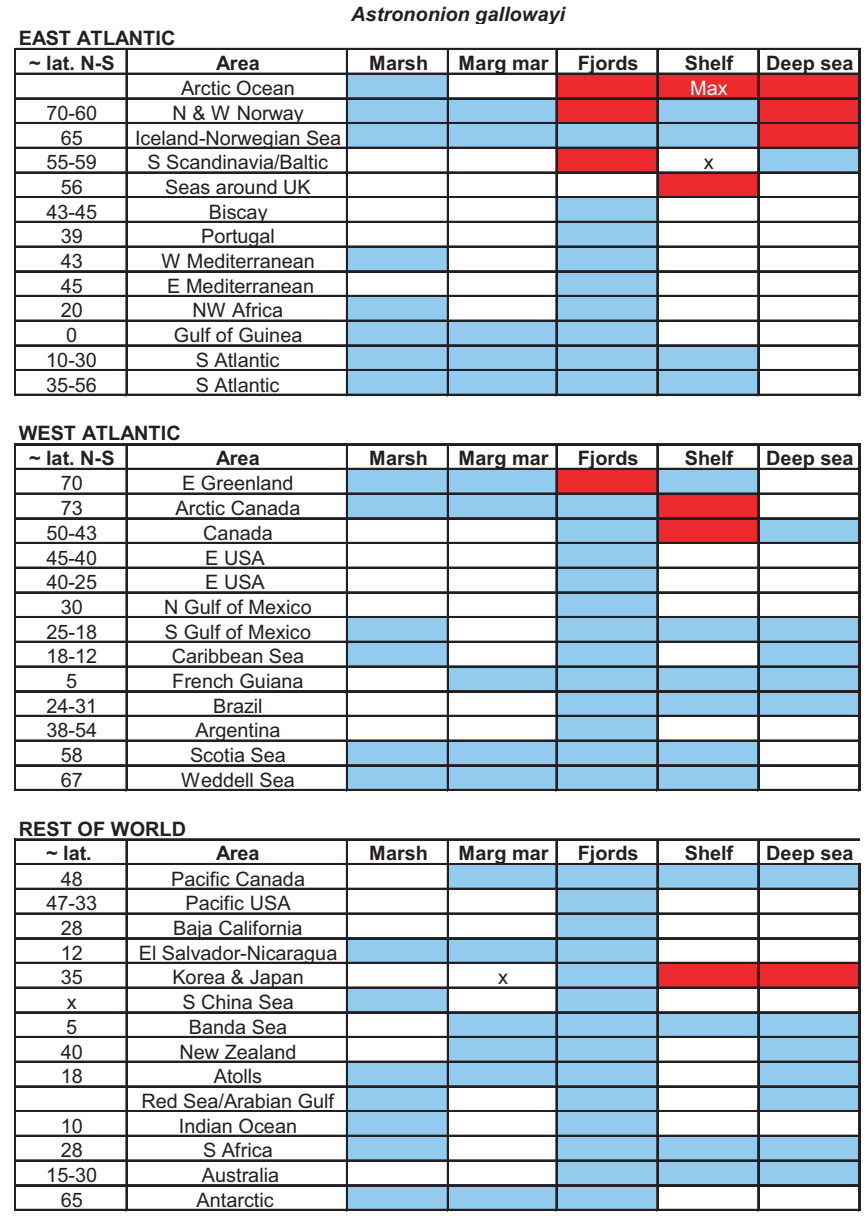

Fig. 40. Astrononion gallowayi.

Arctic Ocean to the North Sea and English Channel off Europe and to the Grand Banks off Canada, and deep sea from the Arctic Ocean to the Iceland-Faroe ridge. It is also recorded on the shelf and slope off Japan (Fig. 40). Of the 151 records, $87 \%$ are of abundances $<10 \%$ and the mean value for the whole dataset is $4 \%$. The highest abundances are in fjords and shelf seas. This species favours cold to temperate conditions (the types are from Alaska).

Astrononion sidebottomi. Confined to shallow shelf seas of the Adriatic where it has a low mean abundance (1\%) with a single high value $(11 \%)$ which may represent a reproductive bloom.

Astrononion stelligerum. There are 31 occurrences from shelf (Gulf of Guinea and Argentina), one from marginal marine (Tobago; probably a misidentification) and 7 from deep sea (Gulf of Guinea and South China Sea).

Buliminella elegantissima. This readily identified widely distributed species occurs from marsh to deep sea (Fig. 41) with most occurrences in marginal marine and shelf (Table 2) and it occurs in all the oceans. High abundances are found in very shallow water along the Pacific seaboard of North America from Washington, USA, to Baja California. In the North Sea it is infaunal down to $25 \mathrm{~cm}$ with peak abundance in the $0-4 \mathrm{~cm}$ interval (Moodley, 1990). In the Norwegian Sea it extends down to $896 \mathrm{~m}$. 
Buliminella elegantissima

EAST ATLANTIC
\begin{tabular}{|c|c|c|c|c|c|c|}
\hline$\sim$ lat. N-S & Area & Marsh & Marg mar & Fjords & Shelf & Deep sea \\
\hline & Arctic Ocean & & & & & \\
\hline $70-60$ & N \& W Norway & & & & & \\
\hline 65 & Iceland-Norwegian Sea & & & & & $x$ \\
\hline $55-59$ & S Scandinavia/Baltic & & & $x$ & $x$ & \\
\hline 56 & Seas around UK & & & & & \\
\hline $43-45$ & Biscay & & & & & \\
\hline 39 & Portugal & & & & & \\
\hline 43 & W Mediterranean & & & & & \\
\hline 45 & E Mediterranean & & & & & \\
\hline 20 & NW Africa & & & & & \\
\hline 0 & Gulf of Guinea & & & & & \\
\hline $10-30$ & S Atlantic & & & & & \\
\hline $35-56$ & S Atlantic & & & & & \\
\hline
\end{tabular}

WEST ATLANTIC
\begin{tabular}{|c|c|c|c|c|c|c|}
\hline$\sim$ lat. N-S & Area & Marsh & Marg mar & Fjords & Shelf & Deep sea \\
\hline 70 & E Greenland & & & & & \\
\hline 73 & Arctic Canada & & & & & \\
\hline $50-43$ & Canada & & & & & \\
\hline $45-40$ & E USA & & & & X & \\
\hline $40-25$ & E USA & & & & & \\
\hline 30 & N Gulf of Mexico & & & & & \\
\hline $25-18$ & S Gulf of Mexico & & & & & \\
\hline $18-12$ & Caribbean Sea & & & & & \\
\hline 5 & French Guiana & & & & & \\
\hline $24-31$ & Brazil & & & & & \\
\hline $38-54$ & Argentina & & & & & \\
\hline 58 & Scotia Sea & & & & & \\
\hline 67 & Weddell Sea & & & & & \\
\hline
\end{tabular}

REST OF WORLD
\begin{tabular}{|c|c|c|c|c|c|c|}
\hline$\sim$ lat. & Area & Marsh & Marg mar & Fjords & Shelf & Deep sea \\
\hline 48 & Pacific Canada & & & & & \\
\hline $47-33$ & Pacific USA & & & & & \\
\hline 28 & Baja California & & & & Max & \\
\hline 12 & El Salvador-Nicaragua & & & & & \\
\hline 35 & Korea \& Japan & & & & & \\
\hline $\mathrm{X}$ & S China Sea & & & & & \\
\hline 5 & Banda Sea & & & & & \\
\hline 40 & New Zealand & & & & & \\
\hline 18 & Atolls & & & & & \\
\hline & Red Sea/Arabian Gulf & & & & & \\
\hline 10 & Indian Ocean & & & & $\mathrm{x}$ & \\
\hline 28 & S Africa & & & & & \\
\hline $15-30$ & Australia & & & & & \\
\hline 65 & Antarctic & & & & & $\mathrm{x}$ \\
\hline
\end{tabular}

Fig. 41. Buliminella elegantissima.

Dentalina/Laevidentalina. Laevidentalina lacks the longitudinal costae of Dentalina (Loeblich \& Tappan, 1987). Although numerous species of these genera have been recorded, all are generally rare with the maximum abundance $(7.7 \%)$ occurring in the West Mediterranean in the shelf off Algeria (Milker et al., 2009). There are a few occurrences in marginal marine and fjord but mainly it is present in shelf and especially in deep-sea environments, in the Arctic, Atlantic, Pacific, Indian and Southern oceans (Fig. 42).

Ehrenbergina. Several species have been recorded but they are all so rare that it is appropriate to consider them collectively. Apart from a single occurrence in a lagoon on Tobago, it is otherwise known from shelf (Argentina, Ross Sea), borderland basins off California, USA, and deep sea (Portugal, West Africa, Nicaragua, Scotia Sea, Weddell Sea, and Ross Sea (Fig. 43). All abundances $>10 \%$ are from around Antarctica.

Fissurina. Thirty-six species of Fissurina have been recorded living (in one or more of 708 samples) together with Fissurina sp. in some of the same samples as well as in others, giving a total record of 1071 samples (nearly $15 \%$ of the primary dataset). Several of the minor Fissurina species occur in only one geographical area or in a single environment. However, the genus is widely distributed both geographically and environmentally (Tables 2, 3). It is, therefore, remarkable that abundances $>10 \%$
Dentalina spp.

EAST ATLANTIC
\begin{tabular}{|c|c|c|c|c|c|c|}
\hline$\sim$ lat. N-S & Area & Marsh & Marg mar & Fjords & Shelf & Deep sea \\
\hline & Arctic Ocean & & & $\mathrm{x}$ & & \\
\hline $70-60$ & N \& W Norway & & & & & \\
\hline 65 & Iceland-Norwegian Sea & & & & & $\mathrm{X}$ \\
\hline $55-59$ & S Scandinavia/Baltic & & & & & \\
\hline 56 & Seas around UK & & & & & \\
\hline $43-45$ & Biscay & & & & $\mathrm{x}$ & \\
\hline 39 & Portugal & & & & $\mathrm{x}$ & \\
\hline 43 & W Mediterranean & & & & Max & \\
\hline 45 & E Mediterranean & & & & $\mathrm{x}$ & $\mathrm{x}$ \\
\hline 20 & NW Africa & & & & & \\
\hline 0 & Gulf of Guinea & & & & $\mathrm{X}$ & $\mathrm{X}$ \\
\hline $10-30$ & S Atlantic & & & & & \\
\hline $35-56$ & S Atlantic & & & & & \\
\hline
\end{tabular}

WEST ATLANTIC
\begin{tabular}{|c|c|c|c|c|c|c|}
\hline$\sim$ lat. N-S & Area & Marsh & Marg mar & Fjords & Shelf & Deep sea \\
\hline 70 & E Greenland & & & & & \\
\hline 73 & Arctic Canada & & & & $\times$ & \\
\hline $50-43$ & Canada & & & & & \\
\hline $45-40$ & E USA & & & & & \\
\hline $40-25$ & E USA & & & & & \\
\hline 30 & N Gulf of Mexico & & & & & \\
\hline $25-18$ & S Gulf of Mexico & & & & & \\
\hline $18-12$ & Caribbean Sea & & & & & \\
\hline 5 & French Guiana & & & & & \\
\hline $24-31$ & Brazil & & & & & \\
\hline $38-54$ & Argentina & & & & & \\
\hline 58 & Scotia Sea & & & & & $\mathrm{x}$ \\
\hline 67 & Weddell Sea & & & & & $\mathrm{x}$ \\
\hline
\end{tabular}

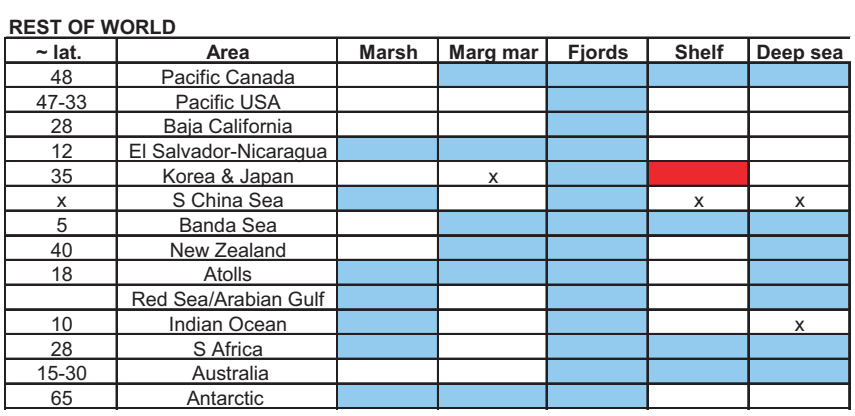

Fig. 42. Dentalina/Laevidentalina spp.

are present in $<1 \%$ of the samples and the mean abundance is merely $1.09 \%$.

Fissurina marginata was interpreted to be an ectoparasite on Discorbis (Le Calvez, 1947) based on observations on live individuals but he did not conduct experiments to prove his interpretation. Other authors have noted a similar positional relationship between Fissurina and a presumed host: $F$. marginata on Cibicides lobatulus (Walker \& Jacob), on Chlamys shells (Haward \& Haynes, 1976); F. submarginata (Boomgart) on Rosalina (Collen \& Newell, 1999). Haward \& Haynes illustrated two F. marginata on an 'arenaceous cover' (i.e. feeding cyst) on Cibicides lobatulus. The protoplasm of the two seemed to be in contact but it is possible that rather than being ectoparasitic the Fissurinas were merely taking food from the feeding cyst (Haynes, pers. comm., 2011). If there is any regular association between these species then they should show some related distributions and abundances. Whereas $C$. lobatulus is very common in current-swept areas, F. marginata is not. The two species behave differently hydrodynamically (one much larger than the other) so this may be part of the explanation for the disparate occurrence of dead tests but it should not affect the living forms. Williamson (1848) recorded F. marginata (as Entosolenia), Rosalina globularis and 'Polystomella crispa' all adhering epifaunally on branching bryozoa but without any obvious association between species. 
Ehrenbergina spp.

EAST ATLANTIC
\begin{tabular}{|c|c|c|c|c|c|c|}
\hline$\sim$ lat. N-S & Area & Marsh & Marg mar & Fjords & Shelf & Deep sea \\
\hline & Arctic Ocean & & & & & \\
\hline $70-60$ & N \& W Norway & & & & & \\
\hline 65 & Iceland-Norwegian Sea & & & & & \\
\hline $55-59$ & S Scandinavia/Baltic & & & & & \\
\hline 56 & Seas around UK & & & & & \\
\hline $43-45$ & Biscay & & & & & \\
\hline 39 & Portugal & & & & & \\
\hline 43 & W Mediterranean & & & & & \\
\hline 45 & E Mediterranean & & & & & \\
\hline 20 & NW Africa & & & & & \\
\hline 0 & Gulf of Guinea & & & & & \\
\hline $10-30$ & S Atlantic & & & & & \\
\hline $35-56$ & S Atlantic & & & & & \\
\hline
\end{tabular}

WEST ATLANTIC
\begin{tabular}{|c|c|c|c|c|c|c|}
\hline$\sim$ lat. N-S & Area & Marsh & Marg mar & Fjords & Shelf & Deep sea \\
\hline 70 & E Greenland & & & & & \\
\hline 73 & Arctic Canada & & & & & \\
\hline $50-43$ & Canada & & & & & \\
\hline $45-40$ & E USA & & & & & \\
\hline $40-25$ & E USA & & & & & \\
\hline 30 & N Gulf of Mexico & & & & & \\
\hline $25-18$ & S Gulf of Mexico & & & & & \\
\hline $18-12$ & Caribbean Sea & & $x$ & & & \\
\hline 5 & French Guiana & & & & & \\
\hline $24-31$ & Brazil & & & & & \\
\hline $38-54$ & Argentina & & & & $x$ & \\
\hline 58 & Scotia Sea & & & & & \\
\hline 67 & Weddell Sea & & & & & \\
\hline
\end{tabular}

REST OF WORLD
\begin{tabular}{|c|c|c|c|c|c|c|}
\hline$\sim$ lat. & Area & Marsh & Marg mar & Fjords & Shelf & Deep sea \\
\hline 48 & Pacific Canada & & & & & \\
\hline $47-33$ & Pacific USA & & & & & \\
\hline 28 & Baja California & & & & & \\
\hline 12 & El Salvador-Nicaragua & & & & & X \\
\hline 35 & Korea \& Japan & & & & & \\
\hline $\mathrm{X}$ & S China Sea & & & & & \\
\hline 5 & Banda Sea & & & & & \\
\hline 40 & New Zealand & & & & & \\
\hline 18 & Atolls & & & & & \\
\hline & Red Sea/Arabian Gulf & & & & & \\
\hline 10 & Indian Ocean & & & & & \\
\hline 28 & S Africa & & & & & \\
\hline $15-30$ & Australia & & & & & \\
\hline 65 & Antarctic & & & & Max & \\
\hline
\end{tabular}

Fig. 43 Ehrenbergina spp.

The supposed ectoparasitic mode of life of $F$. marginata has yet to be demonstrated for other species of Fissurina even though Haynes (1981, p. 54) stated that both Fissurina and Lagena are parasitic on other foraminifera. Haynes (pers. comm., 2011) noted that the case of Lagena 'was suggestive but not conclusive'.

Fissurina laevigata occurs in Arctic fjords and a range of environments in the North Atlantic and Mediterranean but with a single record on a marsh and only three records in the deep sea (Fig. 44) down to $3736 \mathrm{~m}$ in the Gulf of Guinea.

Fissurina lucida. This is by far the most frequently occurring Fissurina species (401 samples) but is geographically restricted, being absent from the Arctic and Southern oceans and the Gulf of Mexico-Caribbean Sea (Fig. 45). It occurs on marshes in northern Spain (27 samples), California (32) and New Zealand (1). The majority of occurrences are in marginal marine environments (236) and shelf seas (122) and it is uncommon in the deep sea (13) where it is recorded down to $1224 \mathrm{~m}$ in the Norwegian Sea. It has not yet been recorded in fjords. This may reflect a preference for somewhat less cool conditions. In a 27-month time-series study of pairs of replicates from two stations in the Hamble estuary, England, it occurred 44 times in the lower intertidal station (sta. 1, close to neap low water) and only 7 times in the mid intertidal station (sta. 2, Murray \& Alve, 2000a). There was great
Fissurina laevigata

\begin{tabular}{|c|c|c|c|c|c|c|}
\hline$\sim$ lat. N-S & Area & Marsh & Marg mar & Fjords & Shelf & Deep sea \\
\hline & Arctic Ocean & & & & & \\
\hline $70-60$ & N \& W Norway & & & $\mathrm{x}$ & & \\
\hline 65 & Iceland-Norwegian Sea & & & & & \\
\hline $55-59$ & S Scandinavia/Baltic & & & & & \\
\hline 56 & Seas around UK & & & & & \\
\hline $43-45$ & Biscay & & & & & \\
\hline 39 & Portugal & & & & & \\
\hline 43 & W Mediterranean & & & & & \\
\hline 45 & E Mediterranean & & & & $\mathrm{x}$ & \\
\hline 20 & NW Africa & & & & & \\
\hline 0 & Gulf of Guinea & & & & & $x$ \\
\hline $10-30$ & S Atlantic & & & & & \\
\hline $35-56$ & S Atlantic & & & & & \\
\hline
\end{tabular}

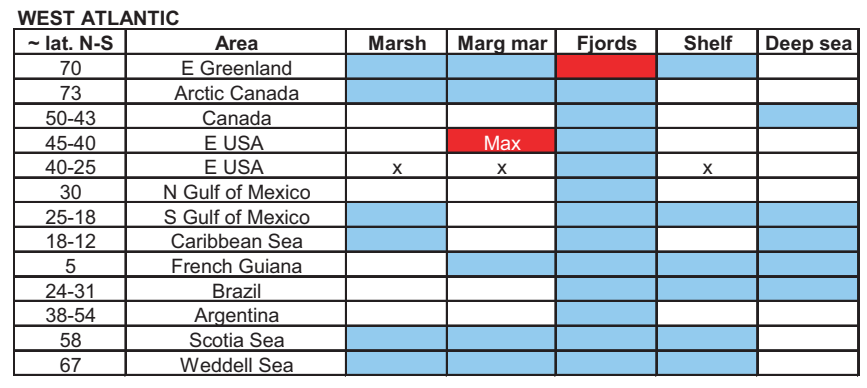

Fig. 44. Fissurina laevigata.

Fissurina lucida
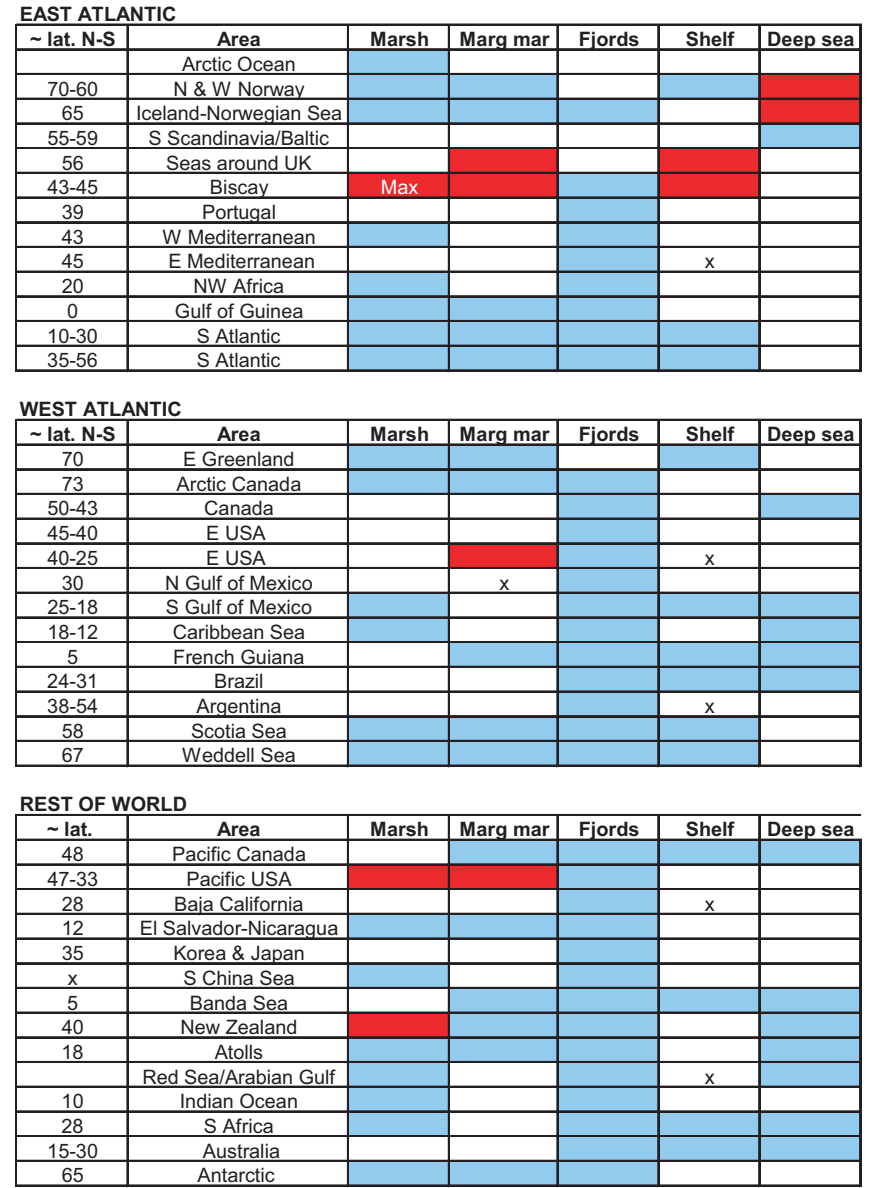

Fig. 45. Fissurina lucida. 


Fissurina marginata
\begin{tabular}{|c|c|c|c|c|c|c|}
\hline EAST ATLANTIC & Mrea & Marsh & Marg mar & Fjords & Shelf & Deep sea \\
\hline$\sim$ & Arctic Ocean & & & & & \\
\hline $70-60$ & N \& W Norway & & & $x$ & & \\
\hline 65 & Iceland-Norwegian Sea & & & & & \\
\hline $55-59$ & S Scandinavia/Baltic & & & & & \\
\hline 56 & Seas around UK & & $x$ & & & \\
\hline $43-45$ & Biscay & & & & & \\
\hline 39 & Portugal & & & & & \\
\hline 43 & W Mediterranean & & & & & \\
\hline 45 & E Mediterranean & & & & & \\
\hline 20 & NW Africa & & & & & \\
\hline 0 & Gulf of Guinea & & & & & \\
\hline $10-30$ & S Atlantic & & & & & \\
\hline $35-56$ & S Atlantic & & & & & \\
\hline
\end{tabular}

WEST ATLANTIC
\begin{tabular}{|c|c|l|l|l|l|l|}
\hline$\sim$ lat. N-S & Area & Marsh & Marg mar & Fjords & Shelf & Deep sea \\
\hline 70 & E Greenland & & & & & \\
\hline 73 & Arctic Canada & & & & & \\
\hline $50-43$ & Canada & & & & & \\
\hline $45-40$ & E USA & & & & & \\
\hline $40-25$ & E USA & & & & & \\
\hline 30 & N Gulf of Mexico & & & & & \\
\hline $25-18$ & S Gulf of Mexico & & & & & \\
\hline $18-12$ & Caribbean Sea & & & & & \\
\hline 5 & French Guiana & & & & & \\
\hline $24-31$ & Brazil & & & & & \\
\hline $38-54$ & Argentina & & & & & \\
\hline 58 & Scotia Sea & & & & & \\
\hline 67 & Weddell Sea & & & & & \\
\hline
\end{tabular}

REST OF WORLD
\begin{tabular}{|c|c|l|l|l|l|l|}
\hline$\sim$ lat. & Area & Marsh & Marg mar & Fjords & Shelf & Deep sea \\
\hline 48 & Pacific Canada & & & & & \\
\hline $47-33$ & Pacific USA & & & & & \\
\hline 28 & Baja California & & & & & \\
\hline 12 & El Salvador-Nicaragua & & & & & \\
\hline 35 & Korea \& Japan & & & & & Max \\
\hline$x$ & S China Sea & & & & & \\
\hline 5 & Banda Sea & & & & & \\
\hline 40 & New Zealand & & & & & \\
\hline 18 & Atolls & & & & & \\
\hline & Red Seal/Arabian Gulf & & & & & \\
\hline 10 & Indian Ocean & & & & & \\
\hline 28 & SAfrica & & & & & \\
\hline $15-30$ & Australia & & & & & \\
\hline 65 & Antarctic & & & & & \\
\hline
\end{tabular}

Fig. 46. Fissurina marginata.

variability in standing crop, biomass and species diversity and no clear correlations with any of the measured environmental parameters, although biomass and diversity seemed to be the best guides to seasonality. Nevertheless, there must be undetected subtle differences between the two stations that make sta. 2 less attractive to F. lucida. Examination under the microscope of live individuals of the associated common species showed no physical association between any of them and F. lucida.

Fissurina marginata. Occurs mainly in the North Atlantic with few occurrences in the Arctic, Pacific and Southern oceans (in the latter as subsp. fissa). It ranges from marginal marine to deep sea (Fig. 46).

Fissurina orbignyana. Occurs in the North Atlantic and Mediterranean (in the latter mainly as subsp. caribaea) primarily on the shelf with a single marginal marine record (Barbuda) and a few in the deep sea (Fig. 47).

Fursenkoina and Stainforthia. Loeblich \& Tappan (1987) place Stainforthia in the Superfamily Turrilinacea and Fursenkoina in the Superfamily Fursenkoinacea, whereas Haynes (1981) placed them both in the Buliminida. Stainforthia is initially triserial then biserial with an optically radial wall, while Fursenkoina is biserial with an optically granular wall. The majority of species in both genera were originally attributed to Virgulina. The species of
Fissurina orbignyana

EAST ATLANTIC
\begin{tabular}{|c|c|c|c|c|c|c|}
\hline$\sim$ lat. N-S & Area & Marsh & Marg mar & Fjords & Shelf & Deep sea \\
\hline & Arctic Ocean & & & & & \\
\hline $70-60$ & N \& W Norway & & & & & \\
\hline 65 & Iceland-Norwegian Sea & & & & $x$ & $x$ \\
\hline $55-59$ & S Scandinavia/Baltic & & & & & \\
\hline 56 & Seas around UK & & & & $x$ & \\
\hline $43-45$ & Biscay & & & & $x$ & \\
\hline 39 & Portugal & & & & & \\
\hline 43 & W Mediterranean & & & & Max & \\
\hline 45 & E Mediterranean & & & & & \\
\hline 20 & NW Africa & & & & & \\
\hline 0 & Gulf of Guinea & & & & & $\times$ \\
\hline $10-30$ & S Atlantic & & & & & \\
\hline $35-56$ & S Atlantic & & & & & \\
\hline
\end{tabular}

WEST ATLANTIC
\begin{tabular}{|c|c|c|l|l|l|l|}
\hline$\sim$ lat. N-S & Area & Marsh & Marg mar & Fjords & Shelf & Deep sea \\
\hline 70 & E Greenland & & & & & \\
\hline 73 & Arctic Canada & & & & & \\
\hline $50-43$ & Canada & & & & & \\
\hline $45-40$ & E USA & & & & & \\
\hline $40-25$ & E USA & & & & & \\
\hline 30 & N Gulf of Mexico & & & & & \\
\hline $25-18$ & S Gulf of Mexico & & & & & \\
\hline $18-12$ & Caribbean Sea & & & & & \\
\hline 5 & French Guiana & & & & & \\
\hline $24-31$ & Brazil & & & & & \\
\hline $38-54$ & Argentina & & & & & \\
\hline 58 & Scotia Sea & & & & & \\
\hline 67 & Weddell Sea & & & & & \\
\hline
\end{tabular}

Fig. 47. Fissurina orbignyana.

Fursenkoina can be divided into those with elongate tests (bramletti, complanata, earlandi, punctata, sandiegoensis, schreibersiana, spinosa) and those with short tests (apertura, mexicana). Fursenkoina pontoni is intermediate.

Fursenkoina apertura. This differs from other species in its very large aperture. The types are from the San Diego Trough in southern California, USA, and all other occurrences are from the Pacific Ocean (San Pedro Basin, California, USA, Japan and Sea of Okhotsk). This is a deep-water species with just a few occurrences shallower than $200 \mathrm{~m}$ (San Diego Trough, Uchio, 1960). In San Pedro Basin the species is most common at $2-3 \mathrm{~cm}$ sediment depth in the $63-150 \mu \mathrm{m}$ fraction in April and October. It is deep infaunal (ALD $3.6 \mathrm{~cm}$ ) in the Okhotsk Sea (Bubenshchikova et al., 2008).

The seasonal deposition of phytodetritus in Sagami Bay, Japan, is related to the spring bloom in phytoplankton (late February to May). In a time-series study in 1997-1998, S. apertura migrated into the phytodetritus layer in May and their protoplasm was green showing that they were feeding on fresh phytodetritus containing chlorophyll- $a$. There was a high concentration of juvenile individuals in the fluffy detritus layer and fewer in the sediment (Kitazato et al., 2000).

Fursenkoina bramletti. This is rare with only 30 occurrences all in California borderland basins, USA.

Fursenkoina complanata. This has a very elongate test with 4-5 chambers in each row. There are scattered records from the Atlantic, Pacific and Southern oceans from marginal marine to deep sea. The greatest abundance is in the deep sea off Japan (Fig. 48).

Fursenkoina earlandi. It looks like a bolivinid rather than Fursenkoina. It occurs in the deep sea in the Gulf of Guinea, South Atlantic, Weddell Sea, Scotia Sea (where it reaches a maximum abundance of $67 \%$ ) and Ross Sea. 
Fursenkina complanata

EAST ATLANTIC
\begin{tabular}{|c|c|c|c|c|c|c|}
\hline$\sim$ lat. N-S & Area & Marsh & Marg mar & Fjords & Shelf & Deep sea \\
\hline & Arctic Ocean & & & & & \\
\hline $70-60$ & N \& W Norway & & & & & \\
\hline 65 & Iceland-Norwegian Sea & & & & & \\
\hline $55-59$ & S Scandinavia/Baltic & & & & & \\
\hline 56 & Seas around UK & & & & & \\
\hline $43-45$ & Biscay & & & & & \\
\hline 39 & Portugal & & & & & \\
\hline 43 & W Mediterranean & & & & & X \\
\hline 45 & E Mediterranean & & & & & \\
\hline 20 & NW Africa & & & & & \\
\hline 0 & Gulf of Guinea & & & & & \\
\hline $10-30$ & S Atlantic & & & & & \\
\hline $35-56$ & S Atlantic & & & & & \\
\hline
\end{tabular}

WEST ATLANTIC
\begin{tabular}{|c|c|c|c|c|c|c|}
\hline$\sim$ lat. N-S & Area & Marsh & Marg mar & Fjords & Shelf & Deep sea \\
\hline 70 & E Greenland & & & & & \\
\hline 73 & Arctic Canada & & & & & \\
\hline $50-43$ & Canada & & & & & \\
\hline $45-40$ & E USA & & & & & \\
\hline $40-25$ & E USA & & & & & \\
\hline 30 & N Gulf of Mexico & & & & $x$ & $x$ \\
\hline $25-18$ & S Gulf of Mexico & & & & & \\
\hline $18-12$ & Caribbean Sea & & $x$ & & & \\
\hline 5 & French Guiana & & & & & \\
\hline $24-31$ & Brazil & & & & & \\
\hline $38-54$ & Argentina & & & & & \\
\hline 58 & Scotia Sea & & & & & \\
\hline 67 & Weddell Sea & & & & & \\
\hline
\end{tabular}

REST OF WORLD
\begin{tabular}{|c|c|c|c|c|c|c|}
\hline$\sim$ lat. & Area & Marsh & Marg mar & Fjords & Shelf & Deep sea \\
\hline 48 & Pacific Canada & & & & & \\
\hline $47-33$ & Pacific USA & & & & & X \\
\hline 28 & Baja California & & & & & \\
\hline 12 & El Salvador-Nicaragua & & & & & \\
\hline 35 & Korea \& Japan & & & & & Max \\
\hline $\mathrm{X}$ & S China Sea & & & & & \\
\hline 5 & Banda Sea & & & & & \\
\hline 40 & New Zealand & & & & & \\
\hline 18 & Atolls & & & & & \\
\hline & Red Sea/Arabian Gulf & & & & & \\
\hline 10 & Indian Ocean & & & & & \\
\hline 28 & S Africa & & & & & \\
\hline $15-30$ & Australia & & & & & \\
\hline 65 & Antarctic & & & & & \\
\hline
\end{tabular}

Fig. 48. Fursenkoina complanata.

Fursenkoina mexicana. It looks like a polymorphinid. There are few occurrences in the marginal marine (Indian River, USA, and NW African shelf), with most from the deep sea from North Africa to the South Atlantic and maximum off Japan.

Fursenkoina pontoni. This was described from the Miocene of Florida, USA. It is confined to the east and west coasts of the USA, the Caribbean and Baja California (Fig. 49). It is the most abundant species of Fursenkoina with nearly half the occurrences $>10 \%$. It occurs primarily in lagoon and shelf environments but it is also recorded from the continental slope in the Gulf of Mexico. Although most records are from sediment samples it is also found to be epiphytal in low abundance on various calcareous algae on Nevis (Wilson, 2007; Wilson \& Ramsook, 2007).

The areas of high abundance are: San Francisco Bay, California, USA (Lesen, 2005), NW Gulf of Mexico (Phleger, 1951; 1956) and Puerto Rico (Seiglie, 1974). San Francisco Bay is an estuary with turbid water which is of normal salinity in the summer but diluted by runoff during the winter and spring (annual range of salinity 15-32). There are pronounced spring phytoplankton blooms. The standing crop of $F$. pontoni collected monthly over two years ranged from 0 to 304 per $10 \mathrm{~cm}^{3}$ sediment and was positively correlated with sediment TOC, nitrogen, amino acids and chlorophyll- $a$ but not with sediment bacteria. Lesen (2005) suggests that measurement of as many potential food resources as
Fursenkoina pontoni

WEST ATLANTIC
\begin{tabular}{|c|c|c|c|c|c|c|}
\hline$\sim$ lat. N-S & Area & Marsh & Marg mar & Fjords & Shelf & Deep sea \\
\hline 70 & E Greenland & & & & & \\
\hline 73 & Arctic Canada & & & & & \\
\hline $50-43$ & Canada & & & & & \\
\hline $45-40$ & E USA & & & & & \\
\hline $40-25$ & E USA & & $x$ & & & \\
\hline 30 & N Gulf of Mexico & & & & & \\
\hline $25-18$ & S Gulf of Mexico & & & & & \\
\hline $18-12$ & Caribbean Sea & & & & Max & \\
\hline 5 & French Guiana & & & & & \\
\hline $24-31$ & Brazil & & & & & \\
\hline $38-54$ & Argentina & & & & & \\
\hline 58 & Scotia Sea & & & & & \\
\hline 67 & Weddell Sea & & & & & \\
\hline
\end{tabular}

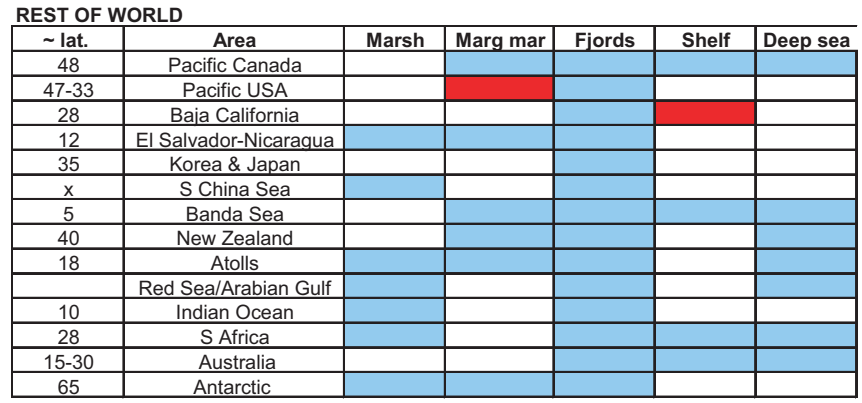

Fig. 49. Fursenkoina pontoni.

WEST ATLANTIC
\begin{tabular}{|c|c|c|c|c|c|c|}
\hline$\sim$ lat. N-S & Area & Marsh & Marg mar & Fjords & Shelf & Deep sea \\
\hline 70 & E Greenland & & & & & \\
\hline 73 & Arctic Canada & & & & & \\
\hline $50-43$ & Canada & & & & & \\
\hline $45-40$ & E USA & & & & & \\
\hline $40-25$ & E USA & & & & & \\
\hline 30 & N Gulf of Mexico & & & & & \\
\hline $25-18$ & S Gulf of Mexico & & & & & \\
\hline $18-12$ & Caribbean Sea & & Max & & & \\
\hline 5 & French Guiana & & & & & \\
\hline $24-31$ & Brazil & & & & & \\
\hline $38-54$ & Argentina & & & & & \\
\hline 58 & Scotia Sea & & & & & \\
\hline 67 & Weddell Sea & & & & & \\
\hline
\end{tabular}

REST OF WORLD

\begin{tabular}{|c|c|c|c|c|c|c|}
\hline$\sim$ lat. & Area & Marsh & Marg mar & Fjords & Shelf & Deep sea \\
\hline 48 & Pacific Canada & & & & & \\
\hline $47-33$ & Pacific USA & & & & & \\
\hline 28 & Baja California & & & & & \\
\hline 12 & El Salvador-Nicaragua & & & & & \\
\hline 35 & Korea \& Japan & & & & & \\
\hline $\mathrm{X}$ & S China Sea & & & & & \\
\hline 5 & Banda Sea & & & & & \\
\hline 40 & New Zealand & & & & & \\
\hline 18 & Atolls & & & & & \\
\hline & Red Sea/Arabian Gulf & & & & & \\
\hline 10 & Indian Ocean & & & & & \\
\hline 28 & S Africa & & & & & \\
\hline $15-30$ & Australia & & & & & \\
\hline 65 & Antarctic & & & & & \\
\hline
\end{tabular}

Fig. 50. Fursenkoina punctata.

possible is necessary to fully evaluate the food supply. The shelf and upper slope in the NW Gulf of Mexico have salinities of $35.5-36$, temperatures of $\sim 10-20^{\circ} \mathrm{C}$ but no records were made of potential food supply. Abundances reach $>10 \%$ in $56 \%$ of the shelf samples and $44 \%$ of those from the slope (down to $227 \mathrm{~m}$ ). The standing crop is $0-111$ per $10 \mathrm{~cm}^{3}$.

The shelf off Puerto Rico has high abundances 0-91\%, mean $41 \%$. The standing crop ranges from $0-321$ per $10 \mathrm{~cm}^{3}$. The inner shelf has salinities of $33.3-36.8$, temperatures of $24-29^{\circ} \mathrm{C}$ and silty clay substrate. The area is subject to pollution from 


Fursenkoina schreibersiana
\begin{tabular}{|c|c|c|c|c|c|c|}
\hline$\sim$ lat. N-S & Area & Marsh & Marg mar & Fjords & Shelf & Deep sea \\
\hline & Arctic Ocean & & & & Max & \\
\hline $70-60$ & N \& W Norway & & & & & \\
\hline 65 & Iceland-Norwegian Sea & & & & & $\times$ \\
\hline $55-59$ & S Scandinavia/Baltic & & & & & \\
\hline 56 & Seas around UK & & & & & \\
\hline $43-45$ & Biscay & & & & $x$ & \\
\hline 39 & Portugal & & & & $x$ & \\
\hline 43 & W Mediterranean & & & & & \\
\hline 45 & E Mediterranean & & & & & \\
\hline 20 & NW Africa & & & & & \\
\hline 0 & Gulf of Guinea & & & & & \\
\hline $10-30$ & S Atlantic & & & & & \\
\hline $35-56$ & S Atlantic & & & & & \\
\hline
\end{tabular}

WEST ATLANTIC
\begin{tabular}{|c|c|c|c|c|c|c|}
\hline$\sim$ lat. N-S & Area & Marsh & Marg mar & Fjords & Shelf & Deep sea \\
\hline 70 & E Greenland & & & & & \\
\hline 73 & Arctic Canada & & & & & \\
\hline $50-43$ & Canada & & & & & \\
\hline $45-40$ & E USA & & & & & \\
\hline $40-25$ & E USA & & & & & \\
\hline 30 & N Gulf of Mexico & & & & & \\
\hline $25-18$ & S Gulf of Mexico & & & & & \\
\hline $18-12$ & Caribbean Sea & & & & & \\
\hline 5 & French Guiana & & & & & \\
\hline $24-31$ & Brazil & & & & & \\
\hline $38-54$ & Argentina & & & & & \\
\hline 58 & Scotia Sea & & & & & \\
\hline 67 & Weddell Sea & & & & & \\
\hline
\end{tabular}

REST OF WORLD
\begin{tabular}{|c|c|l|l|l|l|l|}
\hline lat. & Area & Marsh & Marg mar & Fjords & Shelf & Deep sea \\
\hline 48 & Pacific Canada & & & & & \\
\hline $47-33$ & Pacific USA & & & & & \\
\hline 28 & Baja California & & & & & \\
\hline 12 & El Salvador-Nicaragua & & & & & \\
\hline 35 & Korea \& Japan & & & & & \\
\hline$x$ & S China Sea & & & & & \\
\hline 5 & Banda Sea & & & & & \\
\hline 40 & New Zealand & & & & & \\
\hline 18 & Atolls & & & & & \\
\hline & Red Sea/Arabian Gulf & & & & & \\
\hline 10 & Indian Ocean & & & & & \\
\hline 28 & SAfrica & & & & & \\
\hline $15-30$ & Australia & & & & & \\
\hline 65 & Antarctic & & & & & \\
\hline
\end{tabular}

Fig. 51. Fursenkoina schreibersiana.

industry (fish-canning, animal feed, fertilizer factories) as well as from the human population. Near-bottom dissolved oxygen values range from $4.4-6.8 \mathrm{ppm}$. There had been a change in the microfauna prior to sampling and $F$. pontoni became the dominant species. As no other environmental factor had undergone any major change, the increase was attributed to pollution (although no measurements of pollutants were reported) so this cannot be confirmed.

In summary, $F$. pontoni is a warm-temperate stenohaline species able to tolerate low oxygen conditions and possibly elevated levels of organic pollutants. It is restricted to southern North America and the Caribbean.

Fursenkoina punctata. Occurs in marginal marine environments in the Caribbean (where it reaches its highest abundance) and on the shelf in the Atlantic and Pacific oceans (Fig. 50).

Fursenkoina sandiegoensis. It is found in marginal marine and borderland basins off California, USA, and in the deep sea off El Salvador.

Fursenkoina schreibersiana. This has a few occurrences in marginal marine environments and in the deep sea but is mainly a shelf form with maximum abundance in the Arctic. Most records are from the East Atlantic with a few from the Caribbean and Pacific USA (Fig. 51).
Glandulina spp.

EAST ATLANTIC
\begin{tabular}{|c|c|c|c|c|c|c|}
\hline$\sim$ lat. N-S & Area & Marsh & Marg mar & Fjords & Shelf & Deep sea \\
\hline & Arctic Ocean & & & & & \\
\hline $70-60$ & N \& W Norway & & & $x$ & & \\
\hline 65 & Iceland-Norwegian Sea & & & & & $x$ \\
\hline $55-59$ & S Scandinavia/Baltic & & & & & \\
\hline 56 & Seas around UK & & & & & \\
\hline $43-45$ & Biscay & & & & & $\times$ \\
\hline 39 & Portugal & & & & & $x$ \\
\hline 43 & W Mediterranean & & & & & \\
\hline 45 & E Mediterranean & & & & & \\
\hline 20 & NW Africa & & & & & \\
\hline 0 & Gulf of Guinea & & & & $x$ & \\
\hline $10-30$ & S Atlantic & & & & & \\
\hline $35-56$ & S Atlantic & & & & & \\
\hline
\end{tabular}

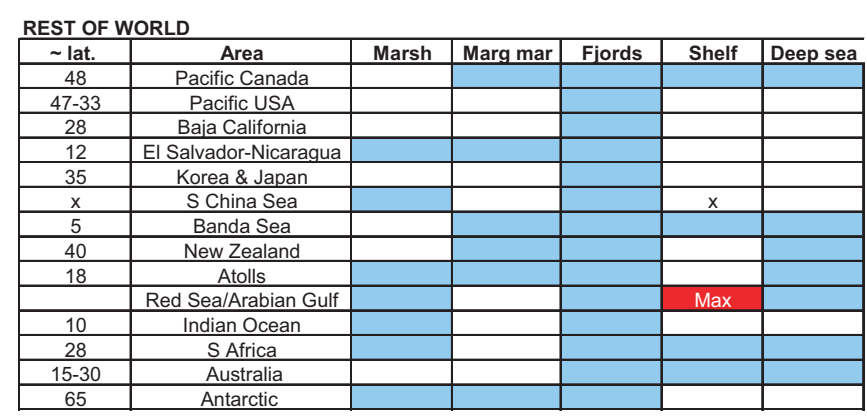

Fig. 52. Glandulina spp..

Glandulina. Most records are of Glandulina laevigata. This genus is restricted to the Arctic, Atlantic and Indian oceans with records from fjord, shelf and deep sea (Fig. 52). The highest abundance is in the slightly hypersaline Arabian Gulf shelf.

Globocassidulina subglobosa. Although there are a few records from marginal marine environments this is essentially a shelf and deep-sea species occurring widely throughout the Atlantic, Pacific and Southern oceans (Fig. 53). It occurs where the mean sea floor organic C flux is $\sim 15 \mathrm{~g} \mathrm{~m}^{2} \mathrm{a}^{-1}$ (Altenbach et al., 1999). The range tolerated in the Gulf of Guinea is $0.8-80 \mathrm{~g} \mathrm{~m}^{2} \mathrm{a}^{-1}$ (Altenbach et al., 2003). Schönfeld (2001) found it to be an oxic species based on measurements of pore water.

Globulina, Vasiglobulina and polymorphinids sensu lato. Many authors treat polymorphinids as a group. They occur in fjords, shelf and deep sea in the Arctic, Atlantic, Mediterranean and Pacific (Fig. 54). Although Globulina and Vasiglobulina span the same range of environments they are primarily shelf forms confined to the Arctic and Atlantic (Fig. 55). Originally the subspecies myristiformis was placed in Globulina gibba but subsequently it was not only raised to species status but transferred to Vasiglobulina. Most records of Globulina are of G. gibba and all are from fjord, shelf or deep sea in the eastern North Atlantic. Vasiglobulina myristiformis is likewise a shelf form known from the NE Atlantic and Mediterranean (Adriatic). Vasiglobulina sp. is recorded from the shelf of eastern USA (listed as a new but unnamed species by Poag et al., 1980). It is permanently anchored to large detrital grains and in this respect differs from Globulina. However, there is no evidence that $V$. myristiformis has an attached mode of life.

Guttulina. The species most widely distributed is Guttulina lactea which occurs in marginal marine, fjord and shelf environments in the North Atlantic with a single occurrence on the shelf off Japan. Guttulina problema, described from the Tertiary of Italy, occurs 
Globocassidulina subglobosa

EAST ATLANTIC
\begin{tabular}{|c|c|c|c|c|c|c|}
\hline$\sim$ lat. N-S & Area & Marsh & Marg mar & Fjords & Shelf & Bathyal \\
\hline & Arctic Ocean & & & & & \\
\hline $70-60$ & N \& W Norway & & & & & \\
\hline 65 & Iceland-Norwegian Sea & & & & & \\
\hline $55-59$ & S Scandinavia/Baltic & & & & & \\
\hline 56 & Seas around UK & & & & & \\
\hline $43-45$ & Biscay & & & & $x$ & $x$ \\
\hline 39 & Portugal & & & & & \\
\hline 43 & W Mediterranean & & & & & $\mathrm{X}$ \\
\hline 45 & E Mediterranean & & & & $\mathrm{X}$ & \\
\hline 20 & NW Africa & & & & & \\
\hline 0 & Gulf of Guinea & & & & & \\
\hline $10-30$ & S Atlantic & & & & & Max \\
\hline $35-56$ & S Atlantic & & & & & \\
\hline
\end{tabular}
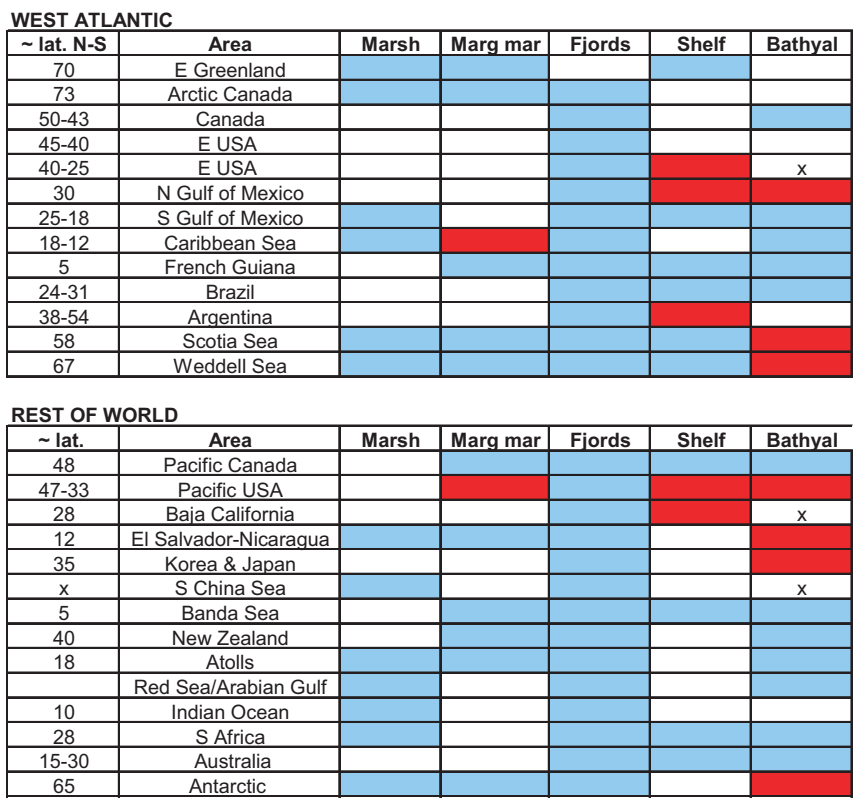

Fig. 53. Globocassidulina subglobosa.

in shelf sediments in the Adriatic Sea and east USA. The other species, G. australis, G. austrica, G. communis, G. harrisi, G. quinqueloba, G. rectiornata and G. yamagazii have very restricted distributions. An unidentified species is very abundant in the $\mathrm{Ob}$ estuary, Russia, with a maximum abundance of $45.4 \%$ and a mean of $15.5 \%$ (5 samples). Considering all Guttulina species together, they occupy marginal marine (in the Arctic), fjord, shelf and deep-sea environments but mostly shelf seas (125 of 151 samples) in the Atlantic and Pacific oceans (Fig. 56).

Gyroidina/Gyroidinoides. There has long been confusion in the assignment of species between Gyroidina and Gyroidinopsis. Loeblich \& Tappan (1987) consider that most species correctly belong in Gyroidinoides or Hansenisca. Fourteen species have stained (living) records and six of these are known only from the deep sea in the Pacific Ocean (broekhiana, gemma, multilocula, nitidula, quinqueloba and rotundimargo), Atlantic (perlucida) and Southern oceans (subplanata). Three species occur in shelf seas as well as the deep sea (neosoldani, orbicularis, umbonata). Gyroidina orbicularis occurs at variable sediment depths down to $8 \mathrm{~cm}$ in Sea of Okhotsk $\mathrm{ALD}_{8} 1.9 \mathrm{~cm}$ (Bubenshchikova et al., 2008). It occurs where the mean sea floor organic $C$ flux is $\sim 3.5 \mathrm{~g} \mathrm{~m}^{2} \mathrm{a}^{-1}$ (Altenbach et al., 1999). Taking all species together the distribution is shelf and deep sea in the East Atlantic and deep
Polymorphinids

EAST ATLANTIC
\begin{tabular}{|c|c|c|c|c|c|c|}
\hline$\sim$ lat. N-S & Area & Marsh & Marg mar & Fjords & Shelf & Deep sea \\
\hline & Arctic Ocean & & & & & Max \\
\hline $70-60$ & N \& W Norway & & & & & \\
\hline 65 & Iceland-Norwegian Sea & & & & & \\
\hline $55-59$ & S Scandinavia/Baltic & & & & $x$ & \\
\hline 56 & Seas around UK & & & & & \\
\hline $43-45$ & Biscay & & & & & X \\
\hline 39 & Portugal & & & & & \\
\hline 43 & W Mediterranean & & & & & X \\
\hline 45 & E Mediterranean & & & & X & \\
\hline 20 & NW Africa & & & & & \\
\hline 0 & Gulf of Guinea & & & & & \\
\hline $10-30$ & S Atlantic & & & & & \\
\hline $35-56$ & S Atlantic & & & & & \\
\hline
\end{tabular}
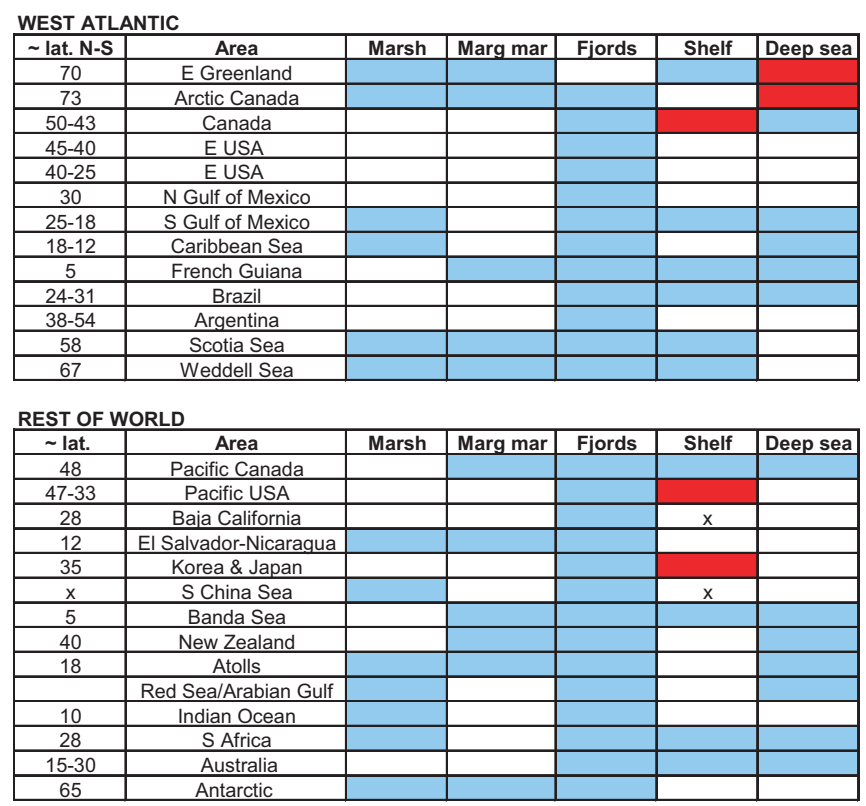

Fig. 54. Polymorphinids.
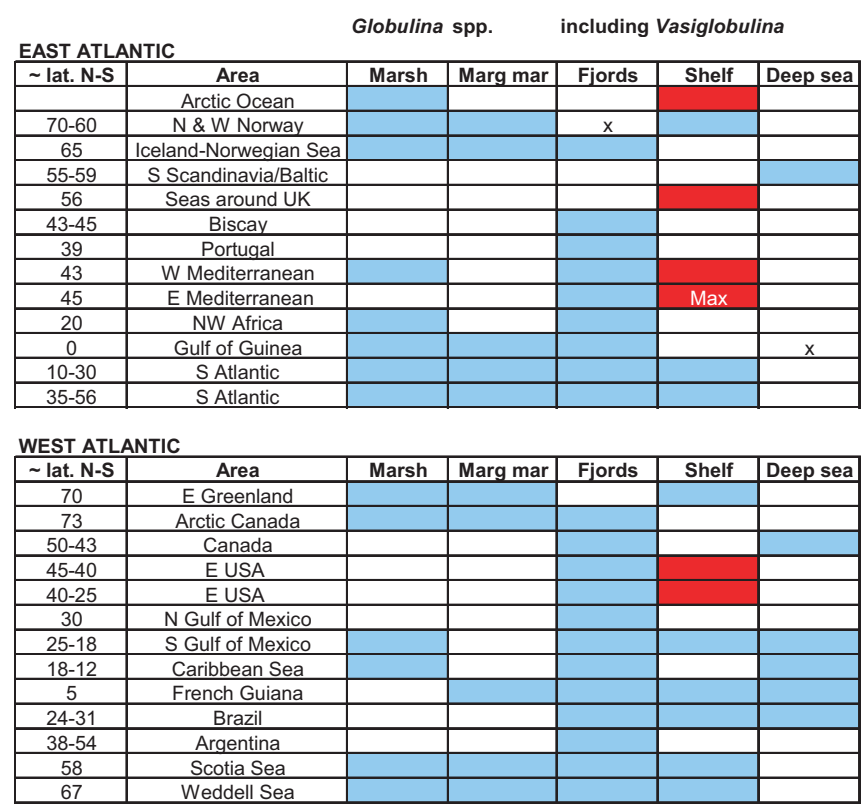

Fig. 55. Globulina and Vasiglobulina. 
Guttulina all spp.

EAST ATLANTIC
\begin{tabular}{|c|c|c|c|c|c|c|}
\hline$\sim$ lat. N-S & Area & Marsh & Marg mar & Fjords & Shelf & Deep sea \\
\hline & Arctic Ocean & & Max & x & x & \\
\hline $70-60$ & N \& W Norway & & & & & \\
\hline 65 & Iceland-Norwegian Sea & & & & & $x$ \\
\hline $55-59$ & S Scandinavia/Baltic & & & & & \\
\hline 56 & Seas around UK & & & & & \\
\hline $43-45$ & Biscay & & $x$ & & $x$ & \\
\hline 39 & Portugal & & & & & \\
\hline 43 & W Mediterranean & & & & & \\
\hline 45 & E Mediterranean & & & & & \\
\hline 20 & NW Africa & & & & & \\
\hline 0 & Gulf of Guinea & & & & & \\
\hline $10-30$ & S Atlantic & & & & & \\
\hline $35-56$ & S Atlantic & & & & & \\
\hline
\end{tabular}

WEST ATLANTIC
\begin{tabular}{|c|c|c|c|c|c|c|}
\hline$\sim$ lat. N-S & Area & Marsh & Marg mar & Fjords & Shelf & Deep sea \\
\hline 70 & E Greenland & & & & & \\
\hline 73 & Arctic Canada & & & & & \\
\hline $50-43$ & Canada & & & & $x$ & \\
\hline $45-40$ & E USA & & & & & \\
\hline $40-25$ & E USA & & & & $x$ & \\
\hline 30 & N Gulf of Mexico & & & & & \\
\hline $25-18$ & S Gulf of Mexico & & $x$ & & & \\
\hline $18-12$ & Caribbean Sea & & & & & \\
\hline 5 & French Guiana & & & & & \\
\hline $24-31$ & Brazil & & & & & \\
\hline $38-54$ & Argentina & & & & & \\
\hline 58 & Scotia Sea & & & & & \\
\hline 67 & Weddell Sea & & & & & \\
\hline
\end{tabular}

REST OF WORLD

REST OF WORLD
\begin{tabular}{|c|c|c|c|c|c|c|}
\hline$\sim$ lat. & Area & Marsh & Marg mar & Fjords & Shelf & Deep sea \\
\hline 48 & Pacific Canada & & & & & \\
\hline $47-33$ & Pacific USA & & & & & \\
\hline 28 & Baja California & & & & & \\
\hline 12 & El Salvador-Nicaragua & & & & & $x$ \\
\hline 35 & Korea \& Japan & & & & & \\
\hline $\mathrm{x}$ & S China Sea & & & & & $\mathrm{X}$ \\
\hline 5 & Banda Sea & & & & & \\
\hline 40 & New Zealand & & & & & \\
\hline 18 & Atolls & & & & & \\
\hline & Red Sea/Arabian Gulf & & & & & \\
\hline 10 & Indian Ocean & & & & & \\
\hline 28 & S Africa & & & & & \\
\hline $15-30$ & Australia & & & & & \\
\hline 65 & Antarctic & & & & & \\
\hline
\end{tabular}

Fig. 56. Guttulina spp.

sea only in the West Atlantic, Pacific and Southern oceans (Fig. 57). In only one out of 573 occurrences is the abundance $>10 \%$ and the mean percentages of all species ranges from 1.03 to $1.74 \%$ (Table 2). In the South Atlantic Gyroidinoides is associated with North Atlantic Deep Water (NADW) (Mackensen et al., 1995).

Haynesina germanica. This has been recorded under various species names, including Protelphidium anglicum and Nonion tisburyensis. It is one of the characteristic shallow infaunal species of marginal marine environments (Murray, 2006). It occurs in $15 \%$ of the samples and has a mean abundance of $28 \%$ (Table 2) and maximum abundances of $100 \%$. There have been several time-series studies of this form (Murray, 1968; Cearreta, 1988; 1989; Murray \& Alve, 2000a) so it is known to be abundant throughout the year rather than just occurring at one season. It is strongly euryhaline, shallow infaunal, and feeds on diatoms and cyanobacteria (Murray, 2006). Molecular genetics shows it to be a single species (Langer, 2000). It is most commonly present in intertidal to shallow subtidal brackish marginal marine environments but it is also present on marshes and there are a few occurrences in fjord and shelf environments (Fig. 58 lower). The North Atlantic and Gulf of Mexico are the main areas of occurrence. In the NE Atlantic the northern limit appears to be southern Scandinavia (Oslofjord, Norway). Its absence from the Baltic cannot be due to a salinity control as the species is euryhaline.
Gyroidina - Gyroidinoides all spp.

EAST ATLANTIC
\begin{tabular}{|c|c|c|c|c|c|c|}
\hline$\sim$ lat. N-S & Area & Marsh & Marg mar & Fjords & Shelf & Deep sea \\
\hline & Arctic Ocean & & & & & \\
\hline $70-60$ & N \& W Norway & & & $x$ & & \\
\hline 65 & Iceland-Norwegian Sea & & & & & \\
\hline $55-59$ & S Scandinavia/Baltic & & & & & \\
\hline 56 & Seas around UK & & & & $x$ & \\
\hline $43-45$ & Biscay & & & & & \\
\hline 39 & Portugal & & & & & \\
\hline 43 & W Mediterranean & & & & & \\
\hline 45 & E Mediterranean & & & & $x$ & \\
\hline 20 & NW Africa & & & & & \\
\hline 0 & Gulf of Guinea & & & & & \\
\hline $10-30$ & S Atlantic & & & & & \\
\hline $35-56$ & S Atlantic & & & & & \\
\hline
\end{tabular}
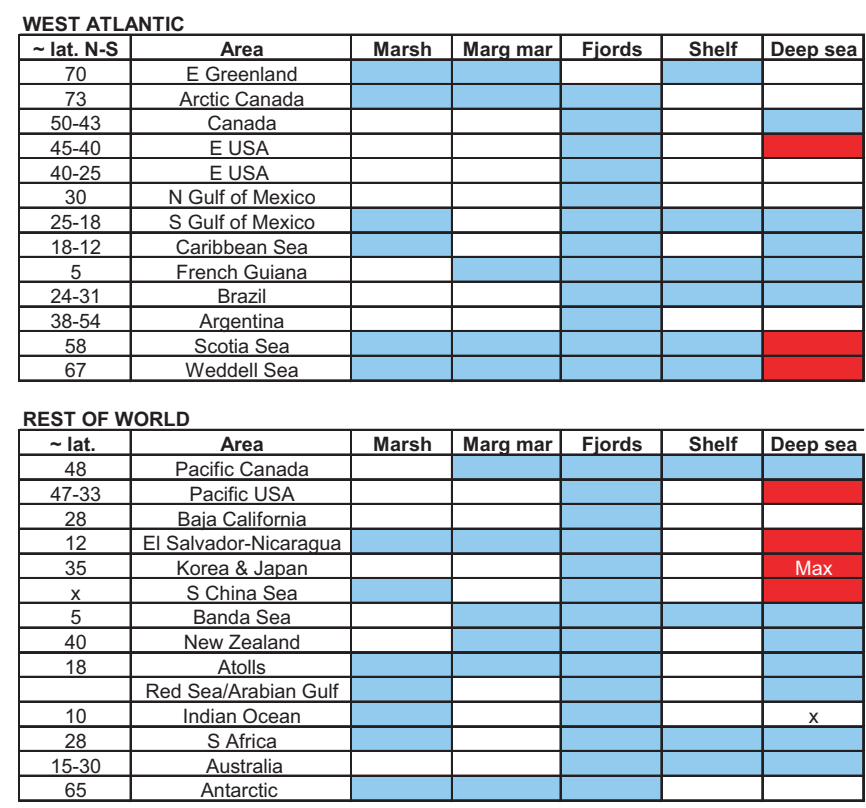

Fig. 57. Gyroidina/Gyroidinoides.

Perhaps the water temperature never reaches a level suitable for reproduction. In the Adriatic it avoids substrates with seagrass and higher amounts of blue-green algae and shows a good correlation with the diatom Nitzschia as a food source (Hohenegger et al., 1989). In the NW Atlantic its northern limits vary: it does not occur in marshes north of Georgia or in marginal marine environments north of Cape Cod. The only record in the Pacific Ocean is from marsh in New Zealand.

Under experimental conditions sediment collected from 140 and $195 \mathrm{~m}$ from Oslofjord was kept in small sealed jars (to simulate shallow-water conditions) for 34 weeks at the end of which small Haynesina germanica were present in some of the containers although they were not present in the samples when collected (Alve \& Goldstein, 2003). Under experimental conditions with varying temperature $\left(12\right.$ and $\left.22^{\circ} \mathrm{C}\right)$ and salinity $(12,22,36)$ it grew abundantly at all salinities and the highest numbers were reached at $12^{\circ} \mathrm{C}$ (Goldstein \& Alve, 2011). When buried in sediment under experimental conditions it did not climb up to the sediment surface (Lee et al., 1969).

Haynesina orbiculare. This is perhaps the cooler-water equivalent of $H$. germanica although it may require warm summer temperatures for reproduction (Scott et al., 1977). It occurs predominantly in marginal marine environments (maximum abundance in Canada) and to a lesser extent in marshes and fjords. It features in 
Haynesina germanica

EAST ATLANTIC
\begin{tabular}{|c|c|c|c|c|c|c|}
\hline$\sim$ lat. N-S & Area & Marsh & Marg mar & Fjords & Shelf & Deep sea \\
\hline & Arctic Ocean & & & & & \\
\hline $70-60$ & N \& W Norway & & & & & \\
\hline 65 & Iceland-Norwegian Sea & & & & & \\
\hline $55-59$ & S Scandinavia/Baltic & & & & & \\
\hline 56 & Seas around UK & Max & & & & \\
\hline $43-45$ & Biscay & & & & & \\
\hline 39 & Portugal & & $x$ & & & \\
\hline 43 & W Mediterranean & & Max & & & \\
\hline 45 & E Mediterranean & & & & & \\
\hline 20 & NW Africa & & & & & \\
\hline 0 & Gulf of Guinea & & & & & \\
\hline $10-30$ & S Atlantic & & & & & \\
\hline $35-56$ & S Atlantic & & & & & \\
\hline
\end{tabular}

WEST ATLANTIC
\begin{tabular}{|c|c|c|c|c|c|c|}
\hline$\sim$ lat. N-S & Area & Marsh & Marg mar & Fjords & Shelf & Deep sea \\
\hline 70 & E Greenland & & & & & \\
\hline 73 & Arctic Canada & & & & & \\
\hline $50-43$ & Canada & & & & & \\
\hline $45-40$ & E USA & & & & & \\
\hline $40-25$ & E USA & & & & & \\
\hline 30 & N Gulf of Mexico & & $x$ & & & \\
\hline $25-18$ & S Gulf of Mexico & & & & & \\
\hline $18-12$ & Caribbean Sea & & & & & \\
\hline 5 & French Guiana & & & & & \\
\hline $24-31$ & Brazil & & & & & \\
\hline $38-54$ & Argentina & & & & & \\
\hline 58 & Scotia Sea & & & & & \\
\hline 67 & Weddell Sea & & & & & \\
\hline
\end{tabular}

REST OF WORLD
\begin{tabular}{|c|c|c|c|c|c|c|}
\hline$\sim$ lat. & Area & Marsh & Marg mar & Fjords & Shelf & Deep sea \\
\hline 48 & Pacific Canada & & & & & \\
\hline $47-33$ & Pacific USA & & & & & \\
\hline 28 & Baja California & & & & & \\
\hline 12 & El Salvador-Nicaragua & & & & & \\
\hline 35 & Korea \& Japan & & & & & \\
\hline $\mathrm{X}$ & S China Sea & & & & & \\
\hline 5 & Banda Sea & & & & & \\
\hline 40 & New Zealand & & & & & \\
\hline 18 & Atolls & & & & & \\
\hline & Red Sea/Arabian Gulf & & & & & \\
\hline 10 & Indian Ocean & & & & & \\
\hline 28 & S Africa & & & & & \\
\hline $15-30$ & Australia & & & & & \\
\hline 65 & Antarctic & & & & & \\
\hline
\end{tabular}

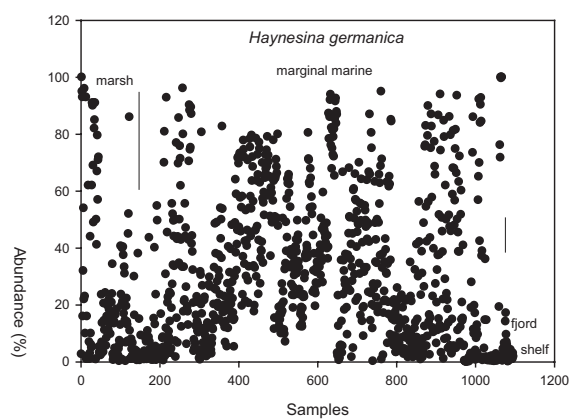

Fig. 58. Haynesina germanica.

the Arctic Ocean and the most southerly occurrence in the NW Atlantic is in Long Island Sound, USA (Fig. 59). The record in Arcachon lagoon, Biscay, is almost certainly a misidentification. In an experiment it was found to be a highly mobile species (Schafer \& Young, 1977).

Helenina anderseni. Apart from occurrences in the Mediterranean this species is absent from the East Atlantic. It occurs on marshes/mangals and in marginal marine environments in the Atlantic seaboard of North America and Caribbean and in the Pacific (Fig. 60). It is found down to $45-50 \mathrm{~cm}$ sediment depth in an Australian mangal (Berkeley et al., 2008).
Haynesina orbiculare

EAST ATLANTIC
\begin{tabular}{|c|c|c|c|c|c|c|}
\hline$\sim$ lat. N-S & Area & Marsh & Marg mar & Fjords & Shelf & Deep sea \\
\hline & Arctic Ocean & & & & & \\
\hline $70-60$ & N \& W Norway & & & & & \\
\hline 65 & Iceland-Norwegian Sea & & & & & \\
\hline $55-59$ & S Scandinavia/Baltic & & & & & \\
\hline 56 & Seas around UK & & & & & \\
\hline $43-45$ & Biscay & & $? ?$ & & & \\
\hline 39 & Portugal & & & & & \\
\hline 43 & W Mediterranean & & & & & \\
\hline 45 & E Mediterranean & & & & & \\
\hline 20 & NW Africa & & & & & \\
\hline 0 & Gulf of Guinea & & & & & \\
\hline $10-30$ & S Atlantic & & & & & \\
\hline $35-56$ & S Atlantic & & & & & \\
\hline
\end{tabular}

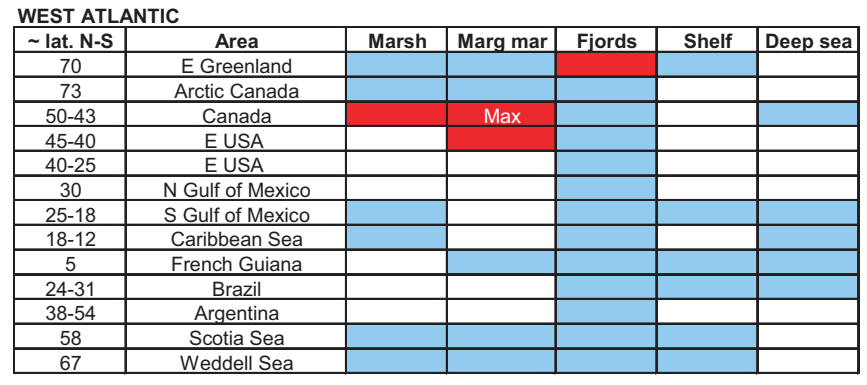

Fig. 59. Haynesina orbiculare.

EAST ATLANTIC
\begin{tabular}{|c|c|c|c|c|c|c|}
\hline$\sim$ lat. N-S S & Area & Marsh & Marg mar & Fjords & Shelf & Deep sea \\
\hline & Arctic Ocean & & & & & \\
\hline $70-60$ & N \& W Norway & & & & & \\
\hline 65 & Iceland-Norwegian Sea & & & & & \\
\hline $55-59$ & S Scandinavia/Baltic & & & & & \\
\hline 56 & Seas around UK & & & & & \\
\hline $43-45$ & Biscay & & & & & \\
\hline 39 & Portugal & & & & & \\
\hline 43 & W Mediterranean & & & & & \\
\hline 45 & E Mediterranean & & & & & \\
\hline 20 & NW Africa & & & & & \\
\hline 0 & Gulf of Guinea & & & & & \\
\hline $10-30$ & S Atlantic & & & & & \\
\hline $35-56$ & S Atlantic & & & & & \\
\hline
\end{tabular}

WEST ATLANTIC
\begin{tabular}{|c|c|c|c|c|c|c|}
\hline$\sim$ lat. N-S & Area & Marsh & Marg mar & Fjords & Shelf & Deep sea \\
\hline 70 & E Greenland & & & & & \\
\hline 73 & Arctic Canada & & & & & \\
\hline $50-43$ & Canada & Max & & & & \\
\hline $45-40$ & E USA & & & & & \\
\hline $40-25$ & E USA & & & & & \\
\hline 30 & N Gulf of Mexico & & & & & \\
\hline $25-18$ & S Gulf of Mexico & & & & & \\
\hline $18-12$ & Caribbean Sea & & & & & \\
\hline 5 & French Guiana & & & & & \\
\hline $24-31$ & Brazil & & & & & \\
\hline $38-54$ & Argentina & & & & & \\
\hline 58 & Scotia Sea & & & & & \\
\hline 67 & Weddell Sea & & & & & \\
\hline
\end{tabular}

\section{REST OF WORLD}

\begin{tabular}{|c|c|c|c|c|c|c|}
\hline$\sim$ lat. & Area & Marsh & Marg mar & Fjords & Shelf & Deep sea \\
\hline 48 & Pacific Canada & & & & & \\
\hline $47-33$ & Pacific USA & & & & & \\
\hline 28 & Baja California & & & & & \\
\hline 12 & El Salvador-Nicaragua & & & & & \\
\hline 35 & Korea \& Japan & & & & & \\
\hline$x$ & S China Sea & & & & $\mathrm{x}$ & \\
\hline 5 & Banda Sea & & & & & \\
\hline 40 & New Zealand & & & & & \\
\hline 18 & Atolls & & & & & \\
\hline & Red Sea/Arabian Gulf & & & & & \\
\hline 10 & Indian Ocean & & & & & \\
\hline 28 & S Africa & & & & & \\
\hline $15-30$ & Australia & & & & & \\
\hline 65 & Antarctic & & & & & \\
\hline
\end{tabular}

Fig. 60. Helenina anderseni. 

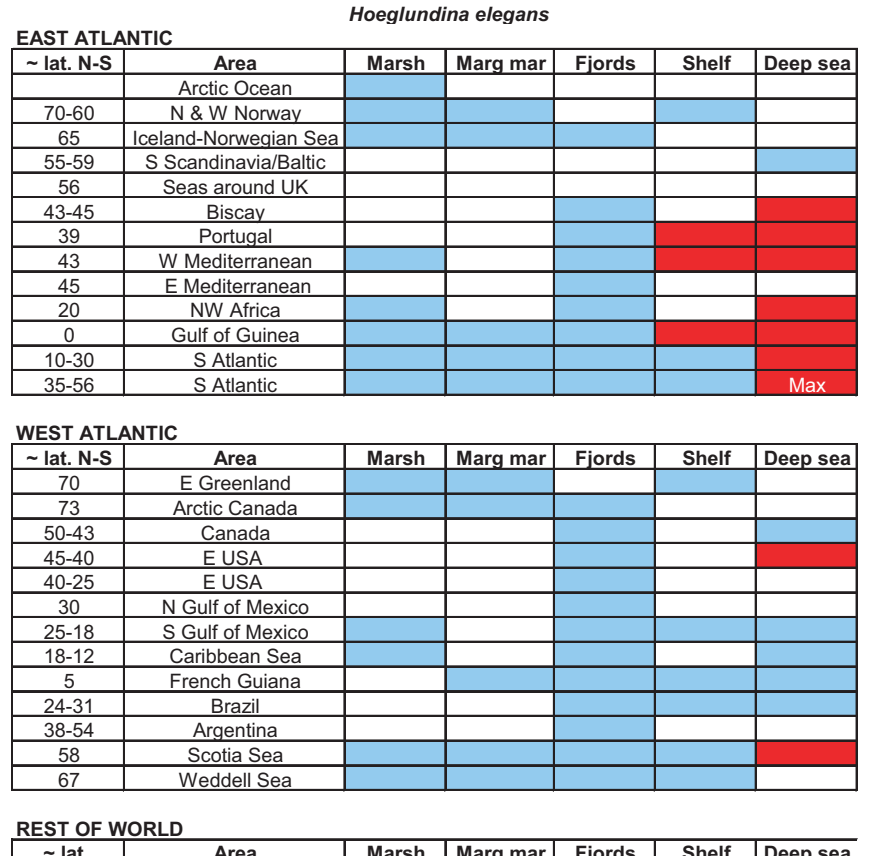

REST OF WORLD
\begin{tabular}{|c|c|c|l|l|c|c|}
\hline$\sim$ lat. & Area & Marsh & Marg mar & Fjords & Shelf & Deep sea \\
\hline 48 & Pacific Canada & & & & & \\
\hline $47-33$ & Pacific USA & & & & & \\
\hline 28 & Baja California & & & & & \\
\hline 12 & El Salvador-Nicaragua & & & & & \\
\hline 35 & Korea \& Japan & & & & & \\
\hline$x$ & S China Sea & & & & & $x$ \\
\hline 5 & Banda Sea & & & & & \\
\hline 40 & New Zealand & & & & & \\
\hline 18 & Atolls & & & & & \\
\hline & Red Sea/Arabian Gulf & & & & & \\
\hline 10 & Indian Ocean & & & & & $x$ \\
\hline 28 & S Africa & & & & & \\
\hline $15-30$ & Australia & & & & & \\
\hline 65 & Antarctic & & & & & \\
\hline
\end{tabular}

Fig. 61. Hoeglundina elegans.

Hoeglundina elegans. This epifaunal aragonitic species from the Atlantic, Pacific and Indian oceans typically occurs on the continental slope but is also known from shelf seas (Fig. 61). High abundance is known from Biscay and the South Atlantic, although the mean abundance is modest. It occurs where the mean sea floor organic $\mathrm{C}$ flux is $10-15 \mathrm{~g} \mathrm{~m}^{2} \mathrm{a}^{-1}$ (Altenbach et al., 1999). In Biscay it occurs in eutrophic to oligotrophic conditions and is shallow infaunal (Fontanier et al., 2002; 2006; Mojtahid et al., 2010). The range tolerated in the Gulf of Guinea is 0.8-62.3 $\mathrm{g} \mathrm{m}^{2} \mathrm{a}^{-1}$ (Altenbach et al., 2003). Schönfeld (2001) found it to be an oxic species based on measurements of pore water. In the South Atlantic it is associated with NADW (Mackensen et al., 1995).

Hopkinsina pacifica atlantica. The occurrences in the Atlantic, Mediterranean, Pacific and Indian oceans are confined to marginal marine and shelf environments (47 and 53\% respectively, Table 2) mainly in temperate settings (Fig. 62). The highest abundance is in marginal marine Tomales Bay, California, USA, in muddy sediments and it is especially abundant in winter (maximum $56 \%$; 28 out of 38 samples $>10 \%$ ). The annual salinity range is $20.3-33.5$ and temperature $7-12^{\circ} \mathrm{C}$ so the species was regarded by the authors as estuarine but it is also correlated with fine-grained sediment (McCormick et al., 1994). On the Adriatic shelf a single station at $32 \mathrm{~m}$ was sampled several times
Hopkinsina pacifica atlantica
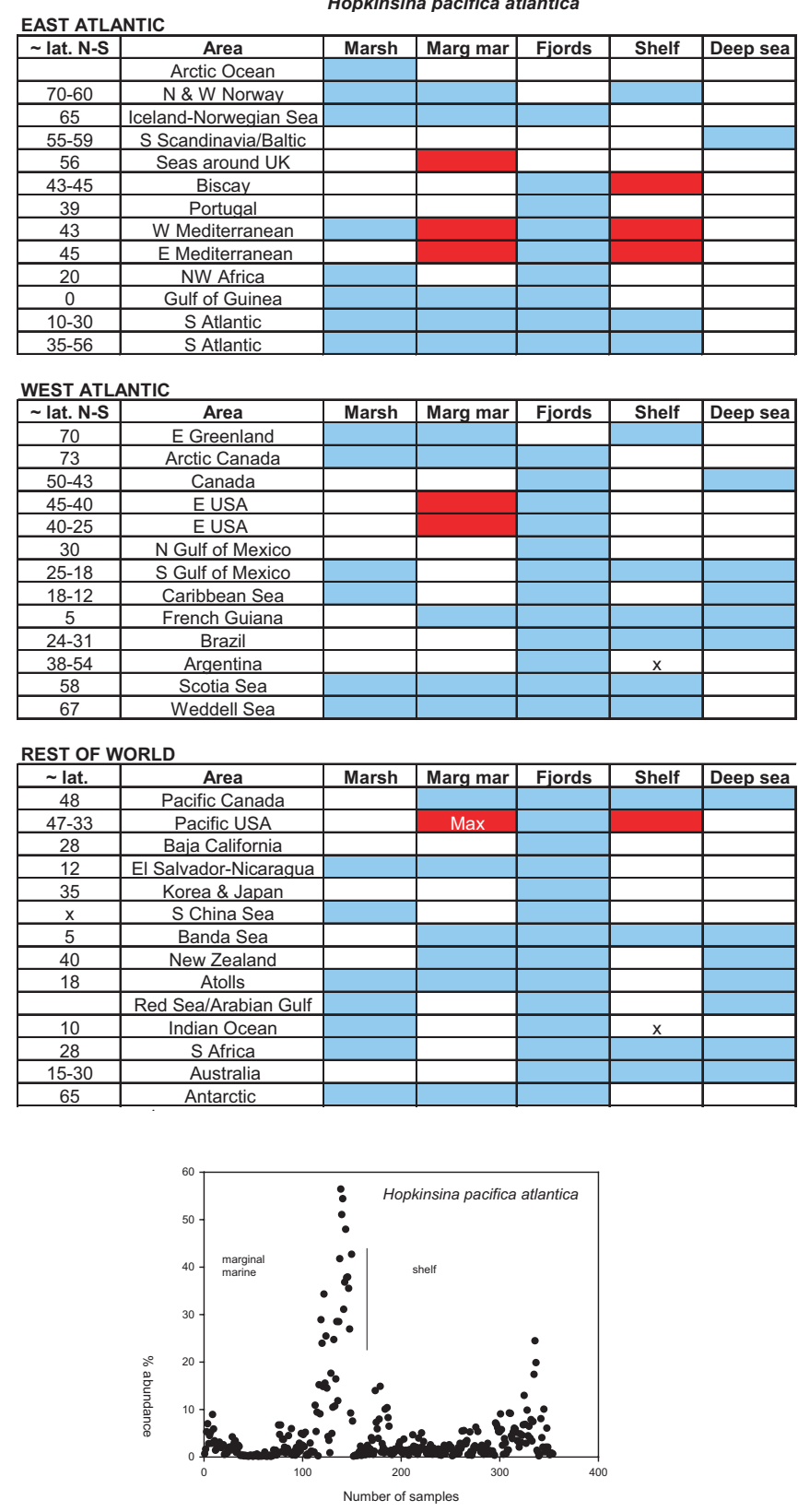

Fig. 62. Hopkinsina pacifica atlantica.

throughout the year. This species occurs predominantly in the top centimetre of the muddy sediment but at different times of the year it also extends down to the maximum depth sampled $(7 \mathrm{~cm})$ so has been described as 'potential infauna' (Barmawidjaja et al., 1992).

Hyalinea balthica. The types are from the Baltic where it was recorded adherent on seaweed. Although there are rare occurrences in the Pacific and Indian oceans, this is essentially a NE Atlantic and Mediterranean species occurring in fjord, shelf and deep sea (Fig. 63). It has peak abundance in the top $\mathrm{cm}$ of sediment in Biscay (Hess \& Jorissen, 2009).

Lagena. Morphospecies of the unilocular genus Lagena can be differentiated only on a few criteria, namely the shape of the chamber, 
Hyalinea balthica

EAST ATLANTIC
\begin{tabular}{|c|c|c|c|c|c|c|}
\hline$\sim$ lat. N-S & Area & Marsh & Marg mar & Fjords & Shelf & Bathyal \\
\hline & Arctic Ocean & & & & $\mathrm{x}$ & \\
\hline $70-60$ & N \& W Norway & & & & & \\
\hline 65 & Iceland-Norwegian Sea & & & & & $\mathrm{X}$ \\
\hline $55-59$ & S Scandinavia/Baltic & & & & & \\
\hline 56 & Seas around UK & & & & & \\
\hline $43-45$ & Biscay & & & & & \\
\hline 39 & Portugal & & & & & \\
\hline 43 & W Mediterranean & & & & & Max \\
\hline 45 & E Mediterranean & & & & $\mathrm{x}$ & \\
\hline 20 & NW Africa & & & & & \\
\hline 0 & Gulf of Guinea & & & & & \\
\hline $10-30$ & S Atlantic & & & & & \\
\hline $35-56$ & S Atlantic & & & & & \\
\hline
\end{tabular}

REST OF WORLD
\begin{tabular}{|c|c|c|c|c|c|c|}
\hline$\sim$ lat. & Area & Marsh & Marg mar & Fjords & Shelf & Bathyal \\
\hline 48 & Pacific Canada & & & & & \\
\hline $47-33$ & Pacific USA & & & & & \\
\hline 28 & Baja California & & & & & \\
\hline 12 & El Salvador-Nicaragua & & & & & \\
\hline 35 & Korea \& Japan & & & & & \\
\hline $\mathrm{x}$ & S China Sea & & & & $\mathrm{x}$ & $\mathrm{x}$ \\
\hline 5 & Banda Sea & & & & & \\
\hline 40 & New Zealand & & & & & \\
\hline 18 & Atolls & & & & & \\
\hline & Red Sea/Arabian Gulf & & & & $\mathrm{x}$ & \\
\hline 10 & Indian Ocean & & & & & \\
\hline 28 & S Africa & & & & & \\
\hline $15-30$ & Australia & & & & & \\
\hline 65 & Antarctic & & & & & \\
\hline
\end{tabular}

Fig. 63. Hyalinea balthica.

the presence or absence of any wall surface texture ('ornament') and the nature of the aperture. Notwithstanding this basically simple morphology, numerous genera have been erected primarily on the shape of the chamber. Here species that have been selected as types of other genera are also considered under Lagena as there seems no benefit in increasing taxonomic confusion by adding these new genera: acuticosta, type of Obliquina Seguenza, 1862; gracilis, type of Procerolagena Puri, 1954; hispidula, type of Pygmaeoseistron Patterson \& Richardson, 1987. It has been claimed that Lagena is parasitic on other foraminifera (Haynes, 1981, p. 54) but no evidence in support of this has been published. MacGillivray observed L. laevis adherent on seaweeds and on the byssus of a modiolid bivalve (cited in Williamson, 1848).

Although more than 30 species of Lagena are recorded in living (stained) assemblages in $10.3 \%$ of the dataset, in only 4 samples out of a total of 825 do they have an abundance $>10 \%$ and their mean abundance is merely $0.82 \%$ so they are undoubtedly rare. Collectively they are distributed in marginal marine to deep sea of all the oceans with just a single record from a mangal. However, individual species show restricted distributions. The highest abundance of Lagena is an unidentified species in an Indonesian mangal (14\%). The other high abundances are all $10 \%$ and from off Japan: L. apiopleura and L. sulcata spicata at $150 \mathrm{~m}$ and L. striata at $300 \mathrm{~m}$.

Lagena clavata. This occurs primarily on shelf seas in the North Atlantic and Adriatic (mean $0.66 \%$ ) with a few occurrences in marginal marine and deep-sea settings in the North Atlantic (Fig. 64).

Lagena gracillima. With a mean abundance of $0.70 \%$ it has a similar geographical distribution to L. clavata but also with occurrences in Arctic Ocean fjords and shelf. In the North Atlantic it occurs primarily in shelf and deep-sea settings.

Lagena laevis. With a mean abundance of $0.74 \%$ it occurs mainly in shelf seas in the North Atlantic but with a single occurrence in
Lagena clavata

EAST ATLANTIC
\begin{tabular}{|c|c|c|c|c|c|c|}
\hline$\sim$ lat. N-S & Area & Marsh & Marg mar & Fjords & Shelf & Deep sea \\
\hline & Arctic Ocean & & & & & \\
\hline $70-60$ & N \& W Norway & & & & & \\
\hline 65 & Iceland-Norwegian Sea & & & & & \\
\hline $55-59$ & S Scandinavia/Baltic & & & & & \\
\hline 56 & Seas around UK & & & & Max & X \\
\hline $43-45$ & Biscay & & & & $\times$ & \\
\hline 39 & Portugal & & & & & \\
\hline 43 & W Mediterranean & & & & & \\
\hline 45 & E Mediterranean & & & & & \\
\hline 20 & NW Africa & & & & & \\
\hline 0 & Gulf of Guinea & & & & & \\
\hline $10-30$ & S Atlantic & & & & & \\
\hline $35-56$ & S Atlantic & & & & & \\
\hline
\end{tabular}

WEST ATLANTIC
\begin{tabular}{|c|c|c|c|c|c|c|}
\hline$\sim$ lat. N-S & Area & Marsh & Marg mar & Fjords & Shelf & Deep sea \\
\hline 70 & E Greenland & & & & & \\
\hline 73 & Arctic Canada & & & & & \\
\hline $50-43$ & Canada & & & & & \\
\hline $45-40$ & E USA & & & & $\times$ & \\
\hline $40-25$ & E USA & & & & & \\
\hline 30 & N Gulf of Mexico & & & & & \\
\hline $25-18$ & S Gulf of Mexico & & & & & \\
\hline $18-12$ & Caribbean Sea & & & & & \\
\hline 5 & French Guiana & & & & & \\
\hline $24-31$ & Brazil & & & & & \\
\hline $38-54$ & Argentina & & & & & \\
\hline 58 & Scotia Sea & & & & & \\
\hline 67 & Weddell Sea & & & & & \\
\hline
\end{tabular}

Fig. 64. Lagena clavata.

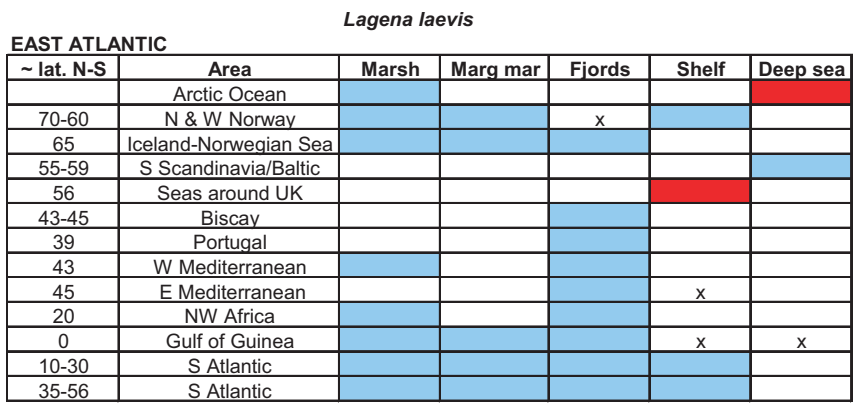

WEST ATLANTIC
\begin{tabular}{|c|c|c|c|c|c|c|}
\hline$\sim$ lat. N-S & Area & Marsh & Marg mar & Fjords & Shelf & Deep sea \\
\hline 70 & E Greenland & & & & & \\
\hline 73 & Arctic Canada & & & & & \\
\hline $50-43$ & Canada & & & & & \\
\hline $45-40$ & E USA & & & & & \\
\hline $40-25$ & E USA & & & & & \\
\hline 30 & N Gulf of Mexico & & & & & \\
\hline $25-18$ & S Gulf of Mexico & & & & & \\
\hline $18-12$ & Caribbean Sea & & & & Max & \\
\hline 5 & French Guiana & & & & & \\
\hline $24-31$ & Brazil & & & & & \\
\hline $38-54$ & Argentina & & & & $x$ & \\
\hline 58 & Scotia Sea & & & & & \\
\hline 67 & Weddell Sea & & & & & \\
\hline
\end{tabular}

Fig. 65. Lagena laevis.

the South Atlantic (Fig. 65). It is also present in the Arctic Ocean down to $374 \mathrm{~m}$ and in a marginal marine lagoon in the Caribbean.

Lagena striata. With a mean abundance of $0.69 \%$ it is most commonly present on the Adriatic Shelf but is also sporadically present in the North and South Atlantic as well as the Pacific (Fig. 66). Its maximum abundance is in the deep sea off Japan (300 m) and it occurs down to $494 \mathrm{~m}$ in the Gulf of Cadiz and $3891 \mathrm{~m}$ in the Gulf of Guinea.

Lagena substriata. With a mean abundance of $0.73 \%$ it is sporadically present from marginal marine to deep sea in the 

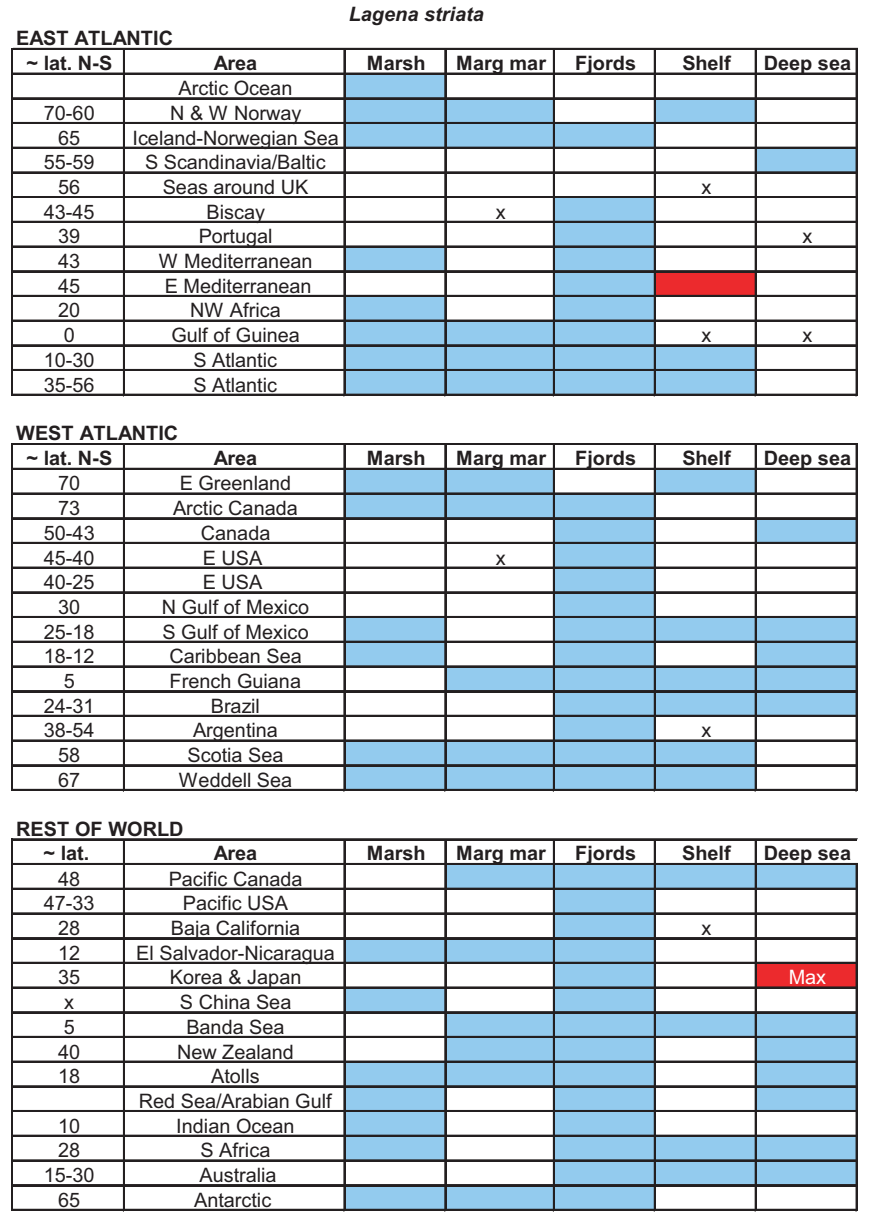

Fig. 66. Lagena striata.

North Atlantic and shelf in the Mediterranean (Fig. 67). In the Norwegian Sea it extends down to $693 \mathrm{~m}$.

Lamarckina haliotidea. This species is generally rare (mean $1.42 \%$ ) and the maximum abundance is $7 \%$ on the shelf off northern Spain (Diz et al., 2004). In this area it is also recorded down to a depth of $9 \mathrm{~cm}$ in the sediment. It occurs sporadically in estuaries in southern England, a Thalassia habitat in Jamaica, and a fjord (Loch Etive, Scotland) but is generally found in shelf environments off NW Europe and eastern USA (Fig. 68). Of the 61 occurrences only 3 are from the USA and Jamaica with a maximum abundance of $0.30 \%$ and a mean of $0.26 \%$.

Laticarinina pauperata. There are surprisingly few records of this species (35) and all are from the deep sea in the Atlantic Ocean, South China and Weddell seas (Fig. 69). Notwithstanding this rarity, 22 live individuals collected from $775 \mathrm{~m}$ off New England, USA, were used in experiments. They were placed on the sediment surface (using sediment from the sampling location) and photographed at regular intervals over a period of days. They moved over and in the sediment and climbed the walls of the containers. Surface tracks were made by individuals moving in a flat position and also by others moving with the test held vertically. Subsurface movement led to cracks in the sediment surface. Feeding traces were arc-shaped and made by the pseudopodia
Lagena substriata

EAST ATLANTIC
\begin{tabular}{|c|c|c|c|c|c|c|}
\hline$\sim$ lat. N-S & Area & Marsh & Marg mar & Fjords & Shelf & Deep sea \\
\hline & Arctic Ocean & & & & & \\
\hline $70-60$ & N \& W Norway & & & $x$ & & \\
\hline 65 & Iceland-Norwegian Sea & & & & & $x$ \\
\hline $55-59$ & S Scandinavia/Baltic & & & & & \\
\hline 56 & Seas around UK & & & & & \\
\hline $43-45$ & Biscay & & & & & \\
\hline 39 & Portugal & & & & & \\
\hline 43 & W Mediterranean & & & & X & \\
\hline 45 & E Mediterranean & & & & & \\
\hline 20 & NW Africa & & & & & \\
\hline 0 & Gulf of Guinea & & & & & \\
\hline $10-30$ & S Atlantic & & & & & \\
\hline $35-56$ & S Atlantic & & & & & \\
\hline
\end{tabular}

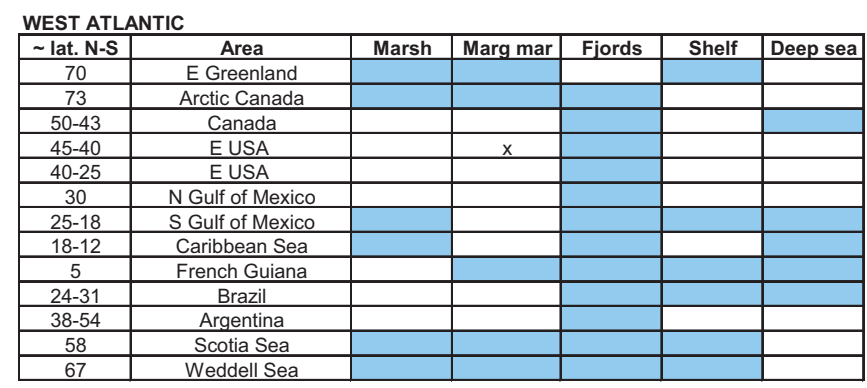

Fig. 67. Lagena substriata.
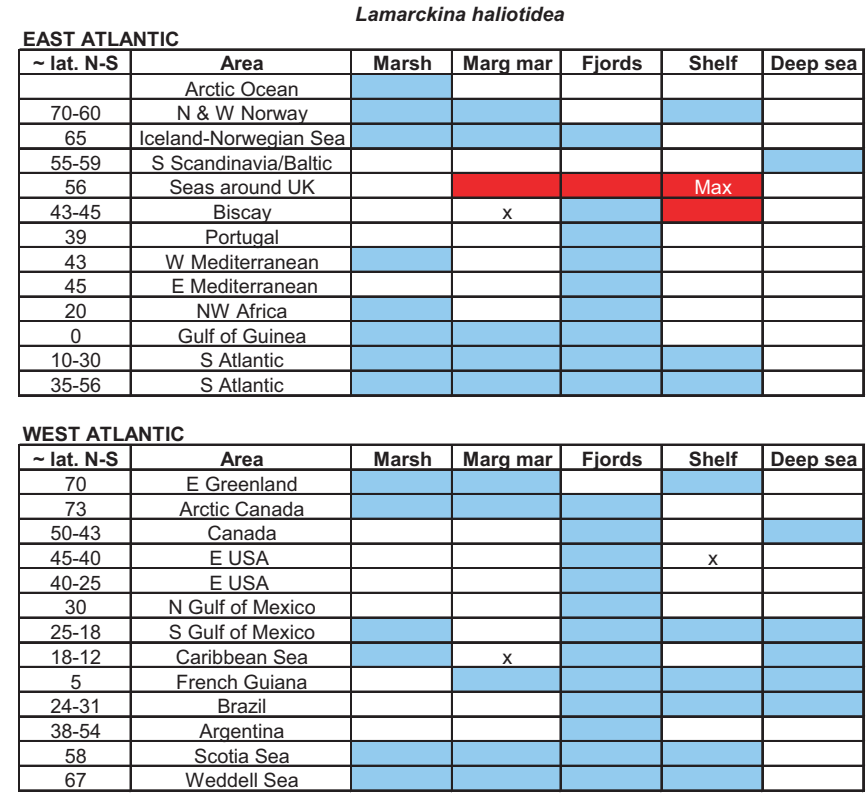

Fig. 68. Lamarckina haliotidea.

moving over the sediment surface. Average daily movements were 16.43 and $11.54 \mathrm{~mm}_{\text {individual }}{ }^{-1}$ for two consecutive months (Weinberg, 1991). The only record of the genus occurring in shelf seas is that of Laticarinina sp. living down to $9 \mathrm{~cm}$ (limit of sampling) in coarse sediments subject to disturbance off northern Spain (Diz et al., 2004).

Lenticulina. Many records are left in open nomenclature but 18 species are also recorded and one of these (peregrina) is sometimes assigned to Neolenticulina. This is primarily a deep-sea species but it also occurs in small numbers on the shelf. With the exception of rare occurrences in the South China Sea this species 
Laticarinina pauperata

EAST ATLANTIC
\begin{tabular}{|c|c|c|c|c|c|c|}
\hline$\sim$ lat. N-S & Area & Marsh & Marg mar & Fjords & Shelf & Deep sea \\
\hline & Arctic Ocean & & & & & \\
\hline $70-60$ & N \& W Norway & & & & & \\
\hline 65 & Iceland-Norwegian Sea & & & & & \\
\hline $55-59$ & S Scandinavia/Baltic & & & & & \\
\hline 56 & Seas around UK & & & & & \\
\hline $43-45$ & Biscay & & & & & \\
\hline 39 & Portugal & & & & & \\
\hline 43 & W Mediterranean & & & & & \\
\hline 45 & E Mediterranean & & & & & \\
\hline 20 & NW Africa & & & & & $\times$ \\
\hline 0 & Gulf of Guinea & & & & & X \\
\hline $10-30$ & S Atlantic & & & & & \\
\hline $35-56$ & S Atlantic & & & & & \\
\hline
\end{tabular}

WEST ATLANTIC
\begin{tabular}{|c|c|c|c|c|c|c|}
\hline$\sim$ lat. N-S & Area & Marsh & Marg mar & Fjords & Shelf & Deep sea \\
\hline 70 & E Greenland & & & & & \\
\hline 73 & Arctic Canada & & & & & \\
\hline $50-43$ & Canada & & & & & \\
\hline $45-40$ & E USA & & & & & \\
\hline $40-25$ & E USA & & & & & \\
\hline 30 & N Gulf of Mexico & & & & & \\
\hline $25-18$ & S Gulf of Mexico & & & & & \\
\hline $18-12$ & Caribbean Sea & & & & & \\
\hline 5 & French Guiana & & & & & \\
\hline $24-31$ & Brazil & & & & & \\
\hline $38-54$ & Argentina & & & & & \\
\hline 58 & Scotia Sea & & & & & \\
\hline 67 & Weddell Sea & & & & & Max \\
\hline
\end{tabular}

REST OF WORLD
\begin{tabular}{|c|c|c|c|c|c|c|}
\hline$\sim$ lat. & Area & Marsh & Marg mar & Fjords & Shelf & Deep sea \\
\hline 48 & Pacific Canada & & & & & \\
\hline $47-33$ & Pacific USA & & & & & \\
\hline 28 & Baja California & & & & & \\
\hline 12 & El Salvador-Nicaragua & & & & & X \\
\hline 35 & Korea \& Japan & & & & & \\
\hline $\mathrm{x}$ & S China Sea & & & & & $\mathrm{X}$ \\
\hline 5 & Banda Sea & & & & & \\
\hline 40 & New Zealand & & & & & \\
\hline 18 & Atolls & & & & & \\
\hline & Red Sea/Arabian Gulf & & & & & \\
\hline 10 & Indian Ocean & & & & & \\
\hline 28 & S Africa & & & & & \\
\hline $15-30$ & Australia & & & & & \\
\hline 65 & Antarctic & & & & & \\
\hline
\end{tabular}

Fig. 69. Laticarinina pauperata.

is confined to the eastern Atlantic. It is tolerant of dysoxic and suboxic pore water but its maximum abundance is in high oxic waters close to the sediment surface, therefore, it is not a reliable indicator of low oxygen conditions (Schönfeld, 2001). With a mean abundance of $0.39 \%$ it occurs very infrequently in marginal marine and fjord and mainly in shelf and deep-sea environments, in the Arctic, Atlantic, Mediterranean, Pacific, Indian and Southern oceans (Fig. 70). The only abundance $>10 \%$ is from the shelf off Japan. Lenticulina gibba (mean $0.48 \%$, maximum $1.72 \%$ ) is found in shelf and deep sea in the North Atlantic, Mediterranean and South China Sea.

Marginulina/Marginulopsis. These genera have been recorded in only 26 samples with an overall mean of $0.41 \%$. Each species is very restricted: bachei (1 record), bradyi (2), glabra (15), obesa (8). All records are from the North Atlantic, Mediterranean and South China Sea shelf and deep sea (maximum $1.32 \%$ off Greenland) (Fig. 71). Marginulina glabra occurs where the mean sea floor organic C flux is $\sim 20 \mathrm{~g} \mathrm{~m}^{2} \mathrm{a}^{-1}$ (Altenbach et al., 1999).

Melonis. Basically there are two morphotypes of Melonis: compressed or inflated. The compressed forms are generally identified as $M$. barleeanum but sometimes as $M$. affinis, M. parkerae or M. zandamae. Some authors have found it impossible to separate
Lenticulina spp.

EAST ATLANTIC
\begin{tabular}{|c|c|c|c|c|c|c|}
\hline$\sim$ lat. N-S & Area & Marsh & Marg mar & Fjords & Shelf & Deep sea \\
\hline & Arctic Ocean & & & & & Max \\
\hline $70-60$ & N \& W Norway & & & & & \\
\hline 65 & Iceland-Norwegian Sea & & & & & \\
\hline $55-59$ & S Scandinavia/Baltic & & & $x$ & $x$ & \\
\hline 56 & Seas around UK & & & & $x$ & \\
\hline $43-45$ & Biscay & & & & $x$ & \\
\hline 39 & Portugal & & & & $x$ & \\
\hline 43 & W Mediterranean & & & & & \\
\hline 45 & E Mediterranean & & & & & X \\
\hline 20 & NW Africa & & & & & $x$ \\
\hline 0 & Gulf of Guinea & & & & & $x$ \\
\hline $10-30$ & S Atlantic & & & & & \\
\hline $35-56$ & S Atlantic & & & & & \\
\hline
\end{tabular}

WEST ATLANTIC
\begin{tabular}{|c|c|c|c|c|c|c|}
\hline$\sim$ lat. N-S & Area & Marsh & Marg mar & Fjords & Shelf & Deep sea \\
\hline 70 & E Greenland & & & & & x \\
\hline 73 & Arctic Canada & & & & & \\
\hline $50-43$ & Canada & & & & & \\
\hline $45-40$ & E USA & & $x$ & & & \\
\hline $40-25$ & E USA & & & & $x$ & \\
\hline 30 & N Gulf of Mexico & & & & & \\
\hline $25-18$ & S Gulf of Mexico & & & & & \\
\hline $18-12$ & Caribbean Sea & & & & & \\
\hline 5 & French Guiana & & & & & \\
\hline $24-31$ & Brazil & & & & & \\
\hline $38-54$ & Argentina & & & & $x$ & \\
\hline 58 & Scotia Sea & & & & & \\
\hline 67 & Weddell Sea & & & & & $x$ \\
\hline
\end{tabular}

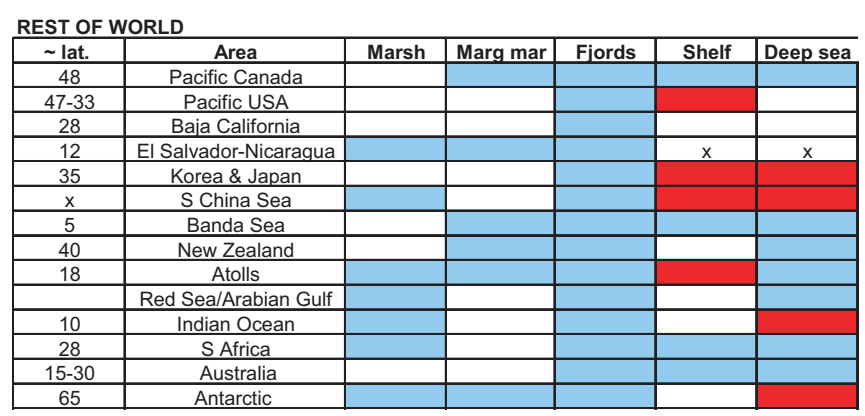

Fig. 70. Lenticulina spp.

barleeanum and zandamae (Schmiedl et al., 1997). The inflated forms are $M$. pompilioides otherwise sometimes called M. sphaeroides

Melonis barleeanum. This is occasionally present in fjords but it is primarily a shelf and deep-sea form occurring widely in the Arctic, Atlantic, Pacific and Southern oceans (Fig. 72). In the Arctic Ocean it occurs in seasonally ice-free areas (Wollenburg \& Mackensen, 1998). The mean values are $6.4 \%$ fjord, $7.5 \%$ shelf and $8 \%$ deep sea and maximum values reach $86 \%$ off Portugal. It is the dominant species in the top $2 \mathrm{~cm}$ of sediment on the continental slope and in canyons off Portugal (Nardelli et al., 2010). In the South Atlantic it is present beneath surface waters showing seasonally varying productivity (Mackensen et al., 1995). It occurs where the mean sea floor organic $\mathrm{C}$ flux is $8 \mathrm{~g} \mathrm{~m}^{2} \mathrm{a}^{-1}$ although it tolerates a much greater range (Altenbach et al., 1999). Off NE Greenland the peak abundance is at $1-3 \mathrm{~cm}$ down core (Ahrens et al., 1997) but in Biscay it is deep infaunal (Fontanier et al., 2003). It shows vertical migration according to changing environmental conditions and availability of food (Linke \& Lutze, 1993). Off Iberia there is tolerance of dysoxic and suboxic pore water but its maximum abundance is in high oxic waters close to the sediment surface so it is not a reliable indicator of low oxygen conditions (Schönfeld, 2001). But elsewhere, it seems to favour dysoxic sediments linked to a redox front (Licari 
Marginulina spp.

EAST ATLANTIC
\begin{tabular}{|c|c|c|c|c|c|c|}
\hline$\sim$ lat. N-S & Area & Marsh & Marg mar & Fjords & Shelf & Deep sea \\
\hline & Arctic Ocean & & & & & \\
\hline $70-60$ & N \& W Norway & & & & & \\
\hline 65 & Iceland-Norwegian Sea & & & & & $\mathrm{x}$ \\
\hline $55-59$ & S Scandinavia/Baltic & & & & & \\
\hline 56 & Seas around UK & & & & & \\
\hline $43-45$ & Biscay & & & & & $\mathrm{X}$ \\
\hline 39 & Portugal & & & & & \\
\hline 43 & W Mediterranean & & & & & \\
\hline 45 & E Mediterranean & & & & $\mathrm{x}$ & \\
\hline 20 & NW Africa & & & & & $\mathrm{X}$ \\
\hline 0 & Gulf of Guinea & & & & $\mathrm{X}$ & \\
\hline $10-30$ & S Atlantic & & & & & \\
\hline $35-56$ & S Atlantic & & & & & \\
\hline
\end{tabular}

WEST ATLANTIC
\begin{tabular}{|c|c|c|c|c|c|c|}
\hline$\sim$ lat. N-S & Area & Marsh & Marg mar & Fjords & Shelf & Deep sea \\
\hline 70 & E Greenland & & & & & Max \\
\hline 73 & Arctic Canada & & & & & \\
\hline $50-43$ & Canada & & & & & \\
\hline $45-40$ & E USA & & & & & \\
\hline $40-25$ & E USA & & & & & \\
\hline 30 & N Gulf of Mexico & & & & & \\
\hline $25-18$ & S Gulf of Mexico & & & & & \\
\hline $18-12$ & Caribbean Sea & & & & & \\
\hline 5 & French Guiana & & & & & \\
\hline $24-31$ & Brazil & & & & & \\
\hline $38-54$ & Argentina & & & & & \\
\hline 58 & Scotia Sea & & & & & \\
\hline 67 & Weddell Sea & & & & & \\
\hline
\end{tabular}

\section{REST OF WORLD}

REST OF WORLD
\begin{tabular}{|c|c|c|c|c|c|c|}
\hline$\sim$ lat. & Area & Marsh & Marg mar & Fjords & Shelf & Deep sea \\
\hline 48 & Pacific Canada & & & & & \\
\hline $47-33$ & Pacific USA & & & & & \\
\hline 28 & Baja California & & & & & \\
\hline 12 & El Salvador-Nicaragua & & & & & \\
\hline 35 & Korea \& Japan & & & & & \\
\hline $\mathrm{x}$ & S China Sea & & & & $\mathrm{x}$ & $\mathrm{x}$ \\
\hline 5 & Banda Sea & & & & & \\
\hline 40 & New Zealand & & & & & \\
\hline 18 & Atolls & & & & & \\
\hline & Red Sea/Arabian Gulf & & & & & \\
\hline 10 & Indian Ocean & & & & & \\
\hline 28 & S Africa & & & & & \\
\hline $15-30$ & Australia & & & & & \\
\hline 65 & Antarctic & & & & & \\
\hline
\end{tabular}

Fig. 71. Marginulina/Marginulopsis.

et al., 2003; Fontanier et al., 2005). It seems to be adapted to live in organic-rich sediments in submarine canyons (Schmiedl et al., 2000). In Biscay it occurs in eutrophic to mesotrophic conditions (Mojtahid et al., 2010). There appears to be a 2-3 month delay between the maximum arrival of food and reproduction because bioturbation is superficial and slows the rate of food transfer into the sediment (Fontanier et al., 2003). In a two-year experiment, where the fauna was deprived of fresh phytodetritus, it increased in abundance indicating that it feeds on degraded food (Alve, 2010) but others have considered that it is independent of the vertical flux of food (Fontanier et al., 2005).

Melonis pompilioides. This is generally less abundant than M. barleeanum (Table 2). There are a few somewhat doubtful records from lagoons in the Caribbean but most occurrences are on the shelf and deep sea in the Atlantic Ocean (Fig. 73). In Biscay it occurs in oligotrophic conditions (Mojtahid et al., 2010). In the South Atlantic it is present beneath surface waters showing seasonally varying productivity (Mackensen et al., 1995).

Nodosaria. With the exception of two records from marginal marine and fjord environments, this genus is otherwise confined to shelf and deep sea (Fig. 74). The mean abundance is $0.60 \%$ and the maximum $2.0 \%$. Half the records are as sp. (26 out of 52)
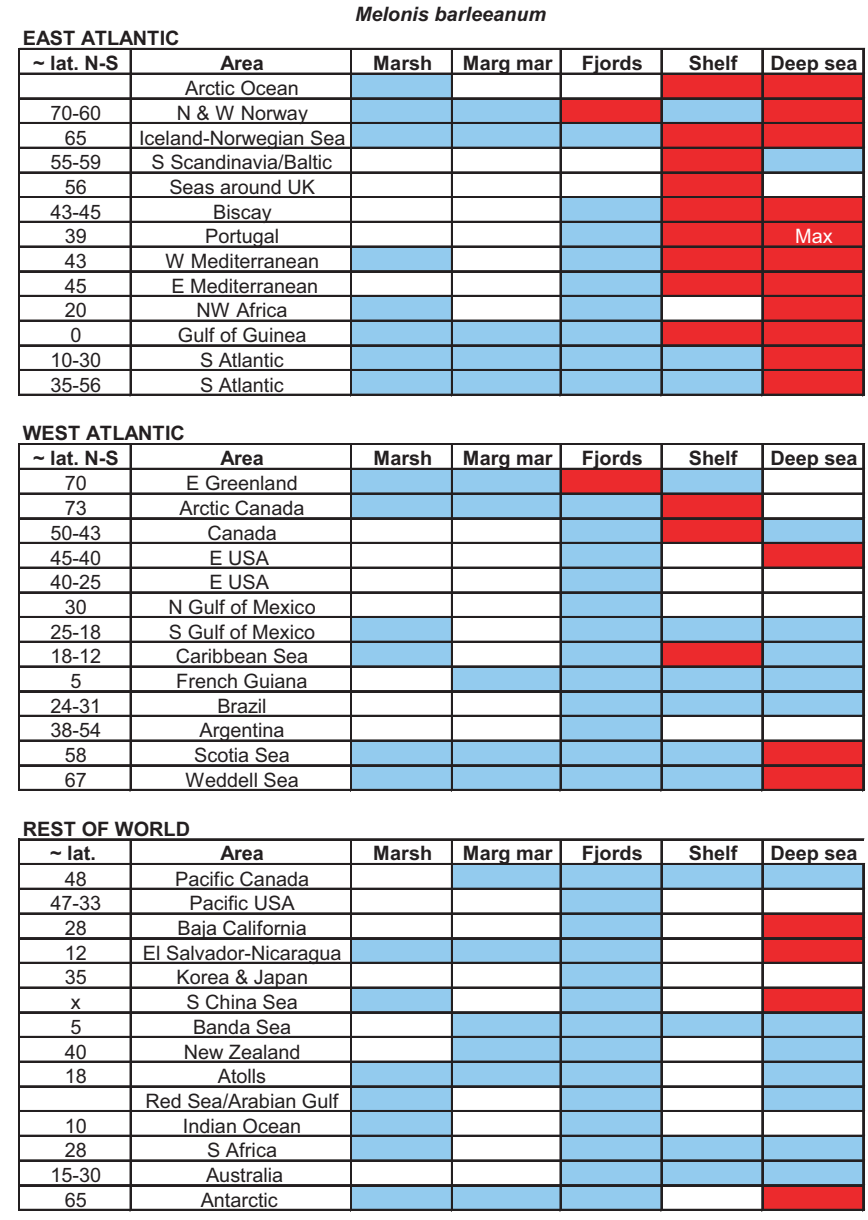

Fig. 72. Melonis barleeanum.
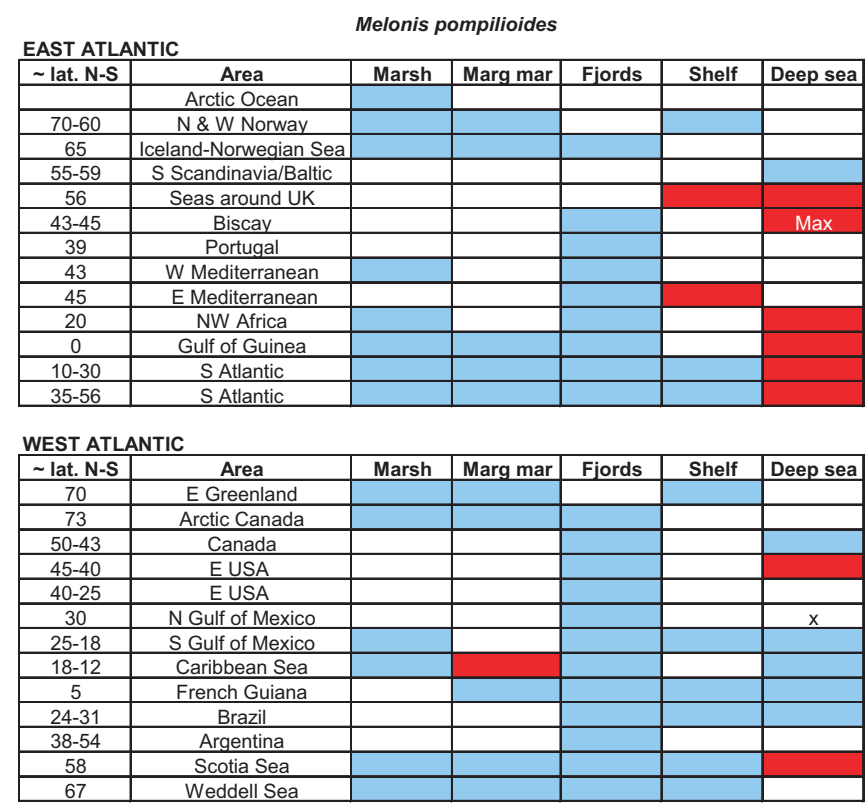

Fig. 73. Melonis pompilioides. 
Nodosaria spp.

EAST ATLANTIC
\begin{tabular}{|c|c|c|c|c|c|c|}
\hline$\sim$ lat. N-S & Area & Marsh & Marg mar & Fjords & Shelf & Deep sea \\
\hline & Arctic Ocean & & & & & \\
\hline $70-60$ & N \& W Norway & & & $x$ & & \\
\hline 65 & Iceland-Norwegian Sea & & & & & Max \\
\hline $55-59$ & S Scandinavia/Baltic & & & & $x$ & \\
\hline 56 & Seas around UK & & & & & \\
\hline $43-45$ & Biscay & & & & & $\mathrm{X}$ \\
\hline 39 & Portugal & & & & & $\mathrm{x}$ \\
\hline 43 & W Mediterranean & & & & & $\mathrm{x}$ \\
\hline 45 & E Mediterranean & & & & $\mathrm{x}$ & \\
\hline 20 & NW Africa & & & & & \\
\hline 0 & Gulf of Guinea & & & & $\mathrm{X}$ & $\mathrm{X}$ \\
\hline $10-30$ & S Atlantic & & & & & \\
\hline $35-56$ & S Atlantic & & & & & \\
\hline
\end{tabular}

WEST ATLANTIC
\begin{tabular}{|c|c|c|c|c|c|c|}
\hline$\sim$ lat. N-S & Area & Marsh & Marg mar & Fjords & Shelf & Deep sea \\
\hline 70 & E Greenland & & & & & \\
\hline 73 & Arctic Canada & & & & & \\
\hline $50-43$ & Canada & & & & & \\
\hline $45-40$ & E USA & & $x$ & & & \\
\hline $40-25$ & E USA & & & & $x$ & \\
\hline 30 & N Gulf of Mexico & & & & & \\
\hline $25-18$ & S Gulf of Mexico & & & & & \\
\hline $18-12$ & Caribbean Sea & & & & & \\
\hline 5 & French Guiana & & & & & \\
\hline $24-31$ & Brazil & & & & & \\
\hline $38-54$ & Argentina & & & & $x$ & \\
\hline 58 & Scotia Sea & & & & & \\
\hline 67 & Weddell Sea & & & & & $\mathrm{x}$ \\
\hline
\end{tabular}

Fig. 74. Nodosaria spp.

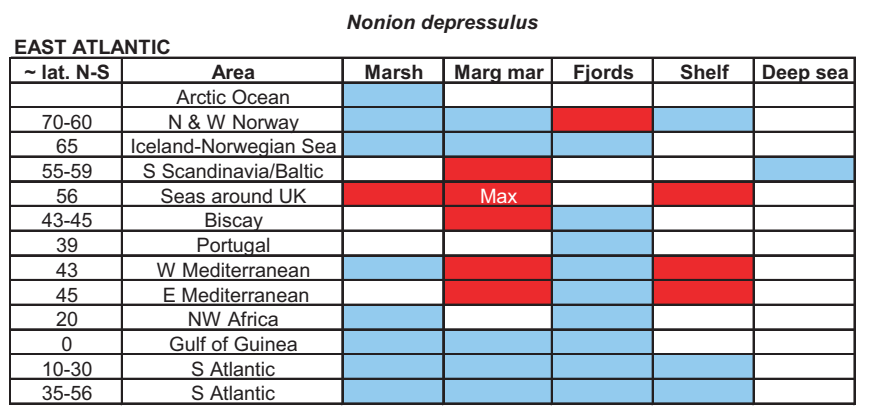

WEST ATLANTIC
\begin{tabular}{|c|c|c|c|c|c|c|}
\hline$\sim$ lat. N-S & Area & Marsh & Marg mar & Fjords & Shelf & Deep sea \\
\hline 70 & E Greenland & & & & & \\
\hline 73 & Arctic Canada & & & & & \\
\hline $50-43$ & Canada & & & & & \\
\hline $45-40$ & E USA & & & & & \\
\hline $40-25$ & E USA & & & & & \\
\hline 30 & N Gulf of Mexico & & & & & \\
\hline $25-18$ & S Gulf of Mexico & & & & & \\
\hline $18-12$ & Caribbean Sea & & & & & \\
\hline 5 & French Guiana & & & & & \\
\hline $24-31$ & Brazil & & & & & \\
\hline $38-54$ & Argentina & & & & & \\
\hline 58 & Scotia Sea & & & & & \\
\hline 67 & Weddell Sea & & & & & \\
\hline
\end{tabular}

\section{REST OF WORLD}

REST OF WORLD
\begin{tabular}{|c|c|c|c|c|c|c|}
\hline$\sim$ lat. & Area & Marsh & Marg mar & Fjords & Shelf & Deep sea \\
\hline 48 & Pacific Canada & & & & & \\
\hline $47-33$ & Pacific USA & & & & & \\
\hline 28 & Baja California & & & & & \\
\hline 12 & El Salvador-Nicaragua & & & & & \\
\hline 35 & Korea \& Japan & & & & & \\
\hline $\mathrm{X}$ & S China Sea & & & & & \\
\hline 5 & Banda Sea & & & & & \\
\hline 40 & New Zealand & & & & & \\
\hline 18 & Atolls & & & & & \\
\hline & Red Sea/Arabian Gulf & & & & & \\
\hline 10 & Indian Ocean & & & & & \\
\hline 28 & S Africa & & & & & \\
\hline $15-30$ & Australia & & & & & \\
\hline 65 & Antarctic & & & & & \\
\hline
\end{tabular}

Fig. 75. Nonion depressulus.
Nonionellina labradorica

EAST ATLANTIC
\begin{tabular}{|c|c|c|c|c|c|c|}
\hline$\sim$ lat. N-S & Area & Marsh & Marg mar & Fjords & Shelf & Deep sea \\
\hline & Arctic Ocean & & & & & \\
\hline $70-60$ & N \& W Norway & & & & & \\
\hline 65 & Iceland-Norwegian Sea & & & & & \\
\hline $55-59$ & S Scandinavia/Baltic & & & & X & \\
\hline 56 & Seas around UK & & & & & \\
\hline $43-45$ & Biscay & & & & & \\
\hline 39 & Portugal & & & & & \\
\hline 43 & W Mediterranean & & & & & \\
\hline 45 & E Mediterranean & & & & & \\
\hline 20 & NW Africa & & & & & \\
\hline 0 & Gulf of Guinea & & & & & \\
\hline $10-30$ & S Atlantic & & & & & \\
\hline $35-56$ & S Atlantic & & & & & \\
\hline
\end{tabular}
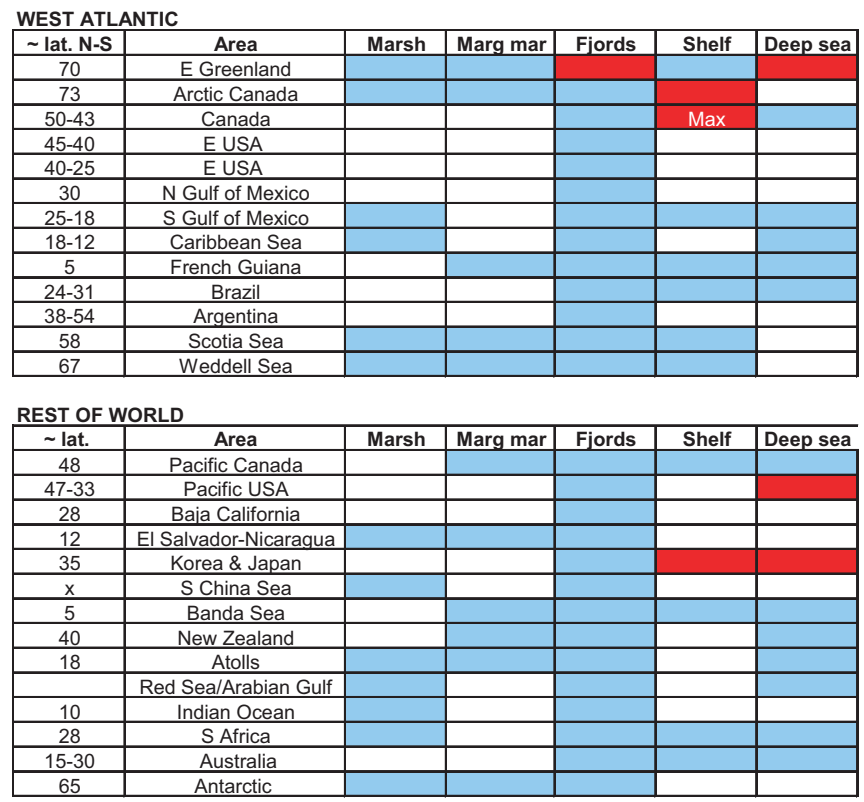

Fig. 76. Nonionellina labradorica.

and individual species have few occurrences: albatrossi (1), calomorpha (12), catesbyi (2), perversa (7), subsoluta (2).

Nonion depressulus. With the exception of occurrences in an Australian mangal (as Haynesina which may be a misidentification for $H$. germanica), this form is confined to the Atlantic Ocean on marsh (rare), marginal marine, fjord and shelf (Fig. 75). In Christchurch Harbour, England, the optimum temperature appeared to be $5-10^{\circ} \mathrm{C}$ (Murray, 1968). This species is abundant in the intertidal zone of the Exe estuary, England, because the salinities are only slightly brackish (Murray, 1980; 1983) and it reproduces every 3-4 months throughout the year. The range of salinity tolerated in marginal marine southern Scandinavia is 2428 (Alve \& Murray, 1999) but the upper limit is higher (35), as seen from the shelf occurrences. In the Adriatic it shows a high correlation with the density of seagrass and to food resources of blue-green algae and diatoms (Hohenegger et al., 1989).

Nonionellina labradorica. More than half the occurrences are in fjords and the rest evenly divided between shelf and deep sea. This is a cold-water species confined to the Arctic, and high-latitude North Atlantic and Pacific oceans (Fig. 76). In the Arctic Ocean it 
occurs in seasonally ice-free areas (Wollenburg \& Mackensen, 1998). Korsun \& Hald $(1998 ; 2000)$ found it to be associated with nutrient-rich glacially-distal areas of fjords where it reproduces in spring in response to the phytoplankton diatom bloom. The maximum abundance of $87.7 \%$ is on the Grand Banks, Canada. The only record from the Pacific seaboard of North America is from cold methane seeps at 500-525 m off northern California, USA, where it occurs in very low numbers down to $3 \mathrm{~cm}$ in the sediment (Rathburn et al., 2000). This is similar to the subsurface depths in the Sea of Okhotsk (Bubenshchikova et al., 2008) and off NE Greenland (Ahrens et al., 1997) although it extends down to $10 \mathrm{~cm}$ in the Barents Sea (Ivanova et al., 2008). It migrated vertically by $\sim 1 \mathrm{~cm}$ in response to experimentally altered oxygen conditions (Alve \& Bernhard, 1995).

Nuttallides pusillus. A deep-sea species found only in the East Atlantic in Biscay, Gulf of Guinea and the South Atlantic, although the types were from off Tasmania, Australia.

Nuttallides umboniferus. Like N. pusillus this is confined to the deep sea in Biscay, Portugal, Gulf of Guinea to the Scotia Sea and Weddell Sea with rare occurrences in the West Mediterranean and off the USA (Fig. 77). In Biscay it occurs in oligotrophic conditions (Mojtahid et al., 2010) in the surface layers of sediment (Fontanier et al., 2002).

Oolina. Although numerous species are recorded they are all rare. There are isolated occurrences in marsh, marginal marine, and fjord but most are from the shelf and deep sea (Fig. 78). The mean is low $(0.86 \%)$ and the maxima $5.88 \%$ and $5.62 \%$ from the shelf and deep sea, respectively.

Oridorsalis. Of the three species discussed two (O. sidebottomi Scotia and Weddell seas and $O$. tener Scotia Sea) are confined to the deep sea, while $O$. umbonatus also rarely extends on to the shelf (Fig. 79). The mean for O. umbonatus is low (3.39\%) but high abundances $(56 \%)$ are attained to the north and west of Norway. It occurs where the mean sea floor organic $\mathrm{C}$ flux is $2 \mathrm{~g} \mathrm{~m}^{2} \mathrm{a}^{-1}$ while that for tener is $3 \mathrm{~g} \mathrm{~m}^{2} \mathrm{a}^{-1}$ (Altenbach et al., 1999). The molecular genetics of bipolar examples of $O$. umbonatus show high similarity (Pawlowski et al., 2007).

Osangularia culter. This deep-sea form is known only from the Gulf of Guinea and SE Atlantic and from the South China Sea.

Patellina corrugata. This is a very distinctive species with little possibility of it being misidentified, as pointed out by Williamson when he named it in 1858. Although Williamson gave no reason for choosing the generic name Patellina it must surely be based on the morphological similarity with the limpet (Patella). With its planoconvex form it has the morphology of an attached or clinging species and this has been confirmed by observation. Myers $(1935 \mathrm{a}, \mathrm{b})$ studied material from tide pools of California, USA, and noted that the tests are attached to various firm substrates 'that support a sparse population of diatoms and other unicellular organisms which may serve as food'. However, the tests were not permanently anchored because when he washed coralline algae from the pool, individuals of $P$. corrugata crawled up the sides of the dish. Unfortunately Myers gave no information about the abundance of the species in the tide pools beyond stating that they
Nuttallides umboniferus
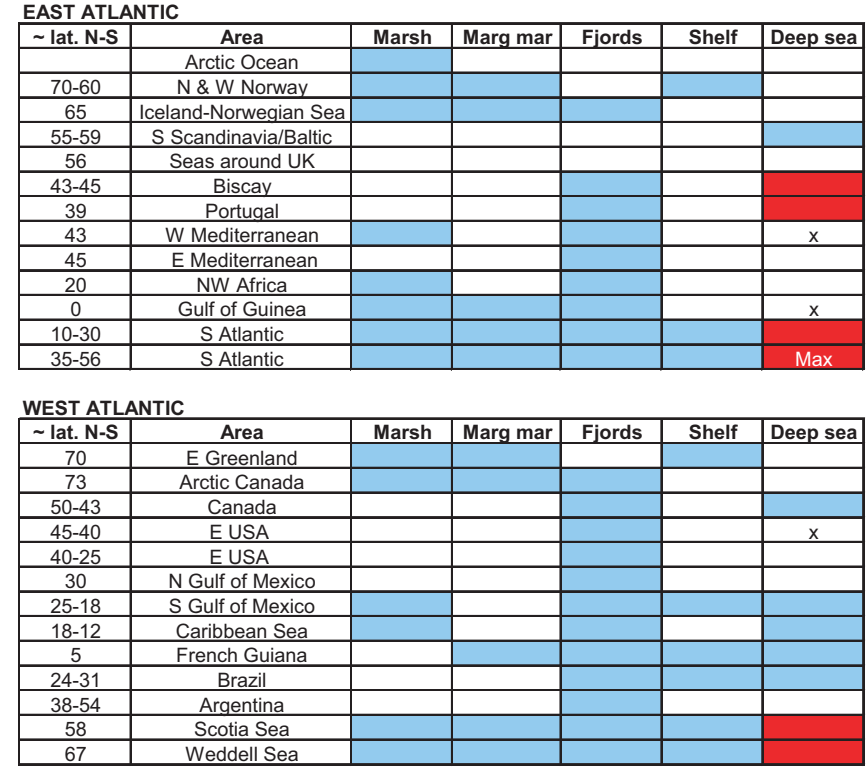

Fig. 77. Nuttallides umboniferus.

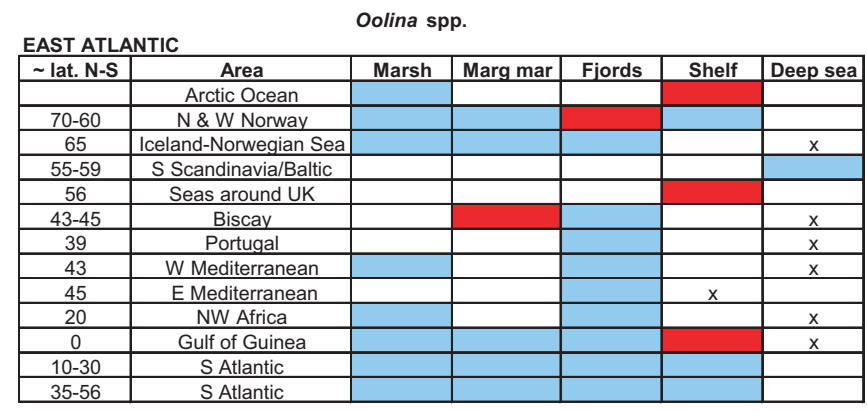

WEST ATLANTIC

WEST ATLANTIC
\begin{tabular}{|c|c|c|c|c|c|c|}
\hline$\sim$ lat. N-S & Area & Marsh & Marg mar & Fjords & Shelf & Deep sea \\
\hline 70 & E Greenland & & & & & $\mathrm{x}$ \\
\hline 73 & Arctic Canada & & & & $\mathrm{x}$ & $\mathrm{x}$ \\
\hline $50-43$ & Canada & & & & & \\
\hline $45-40$ & E USA & & & & & $\mathrm{x}$ \\
\hline $40-25$ & E USA & & & & & \\
\hline 30 & N Gulf of Mexico & & & & & \\
\hline $25-18$ & S Gulf of Mexico & & & & & \\
\hline $18-12$ & Caribbean Sea & & & & & \\
\hline 5 & French Guiana & & & & & \\
\hline $24-31$ & Brazil & & & & & \\
\hline $38-54$ & Argentina & & & & $x$ & \\
\hline 58 & Scotia Sea & & & & & \\
\hline 67 & Weddell Sea & & & & & \\
\hline
\end{tabular}

REST OF WORLD

\begin{tabular}{|c|c|c|c|c|c|c|}
\hline$\sim$ lat. & Area & Marsh & Marg mar & Fjords & Shelf & Deep sea \\
\hline 48 & Pacific Canada & & & & & \\
\hline $47-33$ & Pacific USA & & & & & \\
\hline 28 & Baja California & & & & & \\
\hline 12 & El Salvador-Nicaragua & & & & & \\
\hline 35 & Korea \& Japan & & & & Max & \\
\hline $\mathrm{X}$ & S China Sea & & & & & $\mathrm{X}$ \\
\hline 5 & Banda Sea & & & & & \\
\hline 40 & New Zealand & & & & & \\
\hline 18 & Atolls & & & & & \\
\hline & Red Sea/Arabian Gulf & & & & & \\
\hline 10 & Indian Ocean & & & & & \\
\hline 28 & S Africa & & & & & \\
\hline $15-30$ & Australia & & & & & \\
\hline 65 & Antarctic & & & & & \\
\hline
\end{tabular}

Fig. 78. Oolina spp. 
Oridorsalis umbonatus

EAST ATLANTIC
\begin{tabular}{|c|c|c|c|c|c|c|}
\hline$\sim$ lat. N-S & Area & Marsh & Marg mar & Fjords & Shelf & Deep sea \\
\hline & Arctic Ocean & & & & & \\
\hline $70-60$ & N \& W Norway & & & & & Max \\
\hline 65 & Iceland-Norwegian Sea & & & & & Max \\
\hline $55-59$ & S Scandinavia/Baltic & & & & & \\
\hline 56 & Seas around UK & & & & & \\
\hline $43-45$ & Biscay & & & & & \\
\hline 39 & Portugal & & & & & \\
\hline 43 & W Mediterranean & & & & & \\
\hline 45 & E Mediterranean & & & & & \\
\hline 20 & NW Africa & & & & & \\
\hline 0 & Gulf of Guinea & & & & $x$ & $\times$ \\
\hline $10-30$ & S Atlantic & & & & & \\
\hline $35-56$ & S Atlantic & & & & & \\
\hline
\end{tabular}

WEST ATLANTIC
\begin{tabular}{|c|c|c|c|c|c|c|}
\hline$\sim$ lat. N-S & Area & Marsh & Marg mar & Fjords & Shelf & Deep sea \\
\hline 70 & E Greenland & & & & & \\
\hline 73 & Arctic Canada & & & & & \\
\hline $50-43$ & Canada & & & & & \\
\hline $45-40$ & E USA & & & & & X \\
\hline $40-25$ & E USA & & & & & \\
\hline 30 & N Gulf of Mexico & & & & & \\
\hline $25-18$ & S Gulf of Mexico & & & & & \\
\hline $18-12$ & Caribbean Sea & & & & & \\
\hline 5 & French Guiana & & & & & \\
\hline $24-31$ & Brazil & & & & & \\
\hline $38-54$ & Argentina & & & & & \\
\hline 58 & Scotia Sea & & & & & \\
\hline 67 & Weddell Sea & & & & & \\
\hline
\end{tabular}

\section{REST OF WORLD}

REST OF WORLD
\begin{tabular}{|c|c|c|c|c|c|c|}
\hline$\sim$ lat. & Area & Marsh & Marg mar & Fjords & Shelf & Deep sea \\
\hline 48 & Pacific Canada & & & & & \\
\hline $47-33$ & Pacific USA & & & & & \\
\hline 28 & Baja California & & & & & \\
\hline 12 & El Salvador-Nicaragua & & & & & $x$ \\
\hline 35 & Korea \& Japan & & & & & \\
\hline $\mathrm{x}$ & S China Sea & & & & $\mathrm{x}$ & $\mathrm{x}$ \\
\hline 5 & Banda Sea & & & & & \\
\hline 40 & New Zealand & & & & & \\
\hline 18 & Atolls & & & & & \\
\hline & Red Sea/Arabian Gulf & & & & & \\
\hline 10 & Indian Ocean & & & & & \\
\hline 28 & S Africa & & & & & \\
\hline $15-30$ & Australia & & & & & \\
\hline 65 & Antarctic & & & & & \\
\hline
\end{tabular}

Fig. 79. Oridorsalis umbonatus.

were the source of 'the most plentiful supplies'. However, Cooper (1961) recorded abundances of $<3 \%$ of this species in his study of Californian tide pools.

The life cycle was worked out by Myers (1935a) and Berthold (1976) and the cultures used by the latter were 'derived from a single agamont'. Myers was the first to demonstrate the whole dimorphic life cycle in a foraminiferan. Under experimental conditions maximum gamontogamous (requiring two or more individuals to come together) reproduction occurred at $21^{\circ} \mathrm{C}$ with an (obligatory) alternation of generations occurring on average every 41 days (Myers, 1935b; Goldstein, 1999).

Apart from the localities from around the British Isles listed by Williamson, he recorded $P$. corrugata from Hunde Island off the west coast of Greenland in Davis Strait (material collected by Dr Sutherland, Williamson, 1858, p. xix). Thus, from the start, this species was clearly shown to be widespread.

As $P$. corrugata is a small species (often $<150 \mu \mathrm{m}$ in diameter), it can live clinging to larger sedimentary particles, such as shell fragments and larger sand grains, as well as algae in shallow water. In assessing its geographical distribution, note must be taken of this mode of life. If suitable substrates have not been sampled then it will be absent. The majority of occurrences are from the shelf $(80 \%)$ followed by deep sea $(12 \%)$ with few from marginal marine or fjord. It is present in all the oceans (Fig. 80).
Patellina corrugata

EAST ATLANTIC
\begin{tabular}{|c|c|c|c|c|c|c|}
\hline$\sim$ lat. N-S & Area & Marsh & Marg mar & Fjords & Shelf & Deep sea \\
\hline & Arctic Ocean & & & & & \\
\hline $70-60$ & N \& W Norway & & & X & & \\
\hline 65 & Iceland-Norwegian Sea & & & & & \\
\hline $55-59$ & S Scandinavia/Baltic & & & & & \\
\hline 56 & Seas around UK & & $\mathrm{x}$ & & & \\
\hline $43-45$ & Biscay & & $\mathrm{x}$ & & & \\
\hline 39 & Portugal & & & & & \\
\hline 43 & W Mediterranean & & & & & \\
\hline 45 & E Mediterranean & & & & $\mathrm{X}$ & \\
\hline 20 & NW Africa & & & & & \\
\hline 0 & Gulf of Guinea & & & & & \\
\hline $10-30$ & S Atlantic & & & & & \\
\hline $35-56$ & S Atlantic & & & & & \\
\hline
\end{tabular}
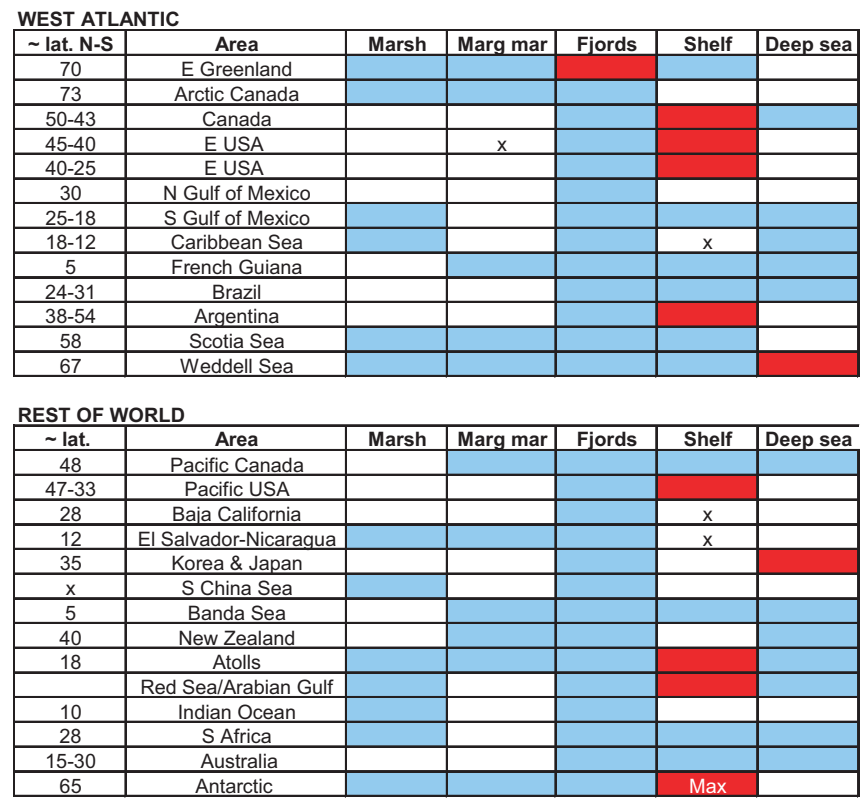

Fig. 80. Patellina corrugata.

The majority of records are from surface sediments but off Vigo, northern Spain, it has been recorded down to $9 \mathrm{~cm}$ in coarse sediment (Diz et al., 2004). In most surface samples its abundance ranges from zero to a few $\%$ but a few blooms are recorded from a Svalbard fjord, the continental shelf off northern Spain, Cape Cod, USA, Argentina and the Antarctic Peninsula. It is especially abundant in protected tide pools off Tierra del Fuego, Argentina, where the surface water temperature is $\sim 6^{\circ} \mathrm{C}$ (Thompson, 1978). Off Antarctic Peninsula the greatest abundance is at 12 and $30 \mathrm{~m}$ water depth in rocky cliff microhabitats with seaweeds which provide a substrate for the foraminifera (Lipps \& DeLaca, 1980). The water temperature there ranges from $-1.5^{\circ} \mathrm{C}$ in winter to $1.8^{\circ} \mathrm{C}$ in summer.

The type area for $P$. corrugata, probably the inner continental shelf off Scotland (Arran or Skye), has a bottom water temperature of $\sim 10^{\circ} \mathrm{C}$ in summer (Lee \& Ramster, 1981). From its widespread distribution this species clearly lives well outside the $21^{\circ} \mathrm{C}$ optimum for reproduction determined experimentally.

Pullenia. The species can be divided into two main groups based on test shape: globular (bulloides, osloensis, subsphaerica); flattened (elegans, quinqueloba, salisburyi, simplex, subcarinata). With the exception of $P$. osloensis all are typically deep sea with limited occurrences on the shelf. 

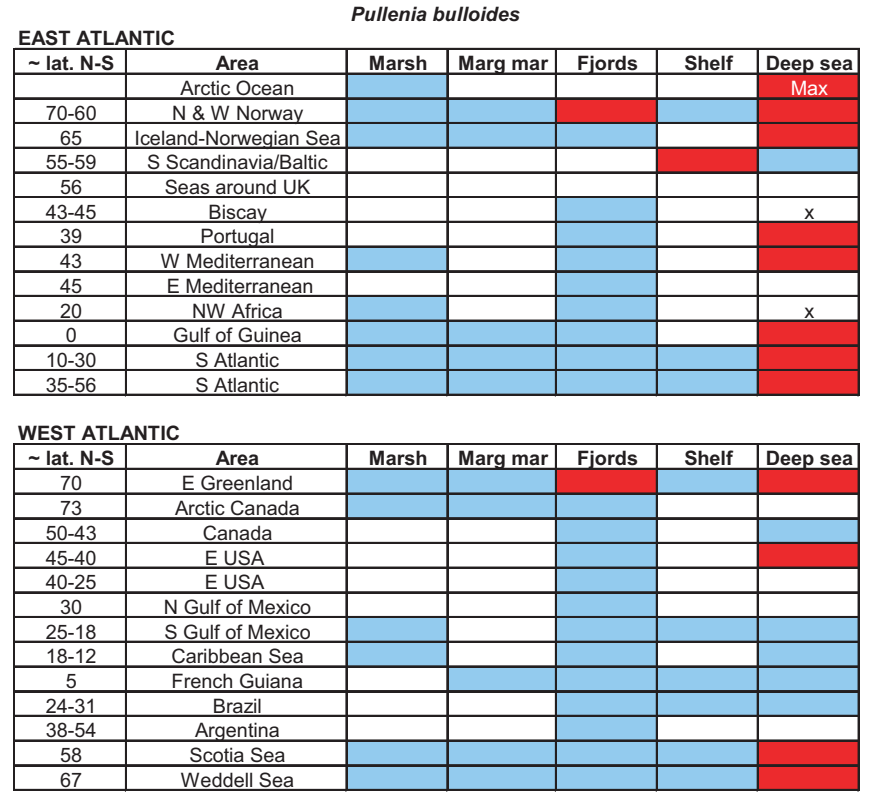

REST OF WORLD
\begin{tabular}{|c|c|l|l|l|c|c|}
\hline$\sim$ lat. & Area & Marsh & Marg mar & Fjords & Shelf & Deep sea \\
\hline 48 & Pacific Canada & & & & & \\
\hline $47-33$ & Pacific USA & & & & & \\
\hline 28 & Baja California & & & & & $x$ \\
\hline 12 & El Salvador-Nicaragua & & & & & $x$ \\
\hline 35 & Korea \& Japan & & & & & \\
\hline $\mathrm{x}$ & S China Sea & & & & & $\times$ \\
\hline 5 & Banda Sea & & & & & \\
\hline 40 & New Zealand & & & & & \\
\hline 18 & Atolls & & & & & \\
\hline & Red SealArabian Gulf & & & & & \\
\hline 10 & Indian Ocean & & & & & \\
\hline 28 & S Africa & & & & & \\
\hline $15-30$ & Australia & & & & & \\
\hline 65 & Antarctic & & & & & \\
\hline
\end{tabular}

Fig. 81. Pullenia bulloides.

Pullenia bulloides. The mean values are generally low, especially in the Pacific Ocean and the maximum is in the Barents Sea (Fig. 81). In the Arctic Ocean it occurs in seasonally ice-free areas (Wollenburg \& Mackensen, 1998). Most records are from the deep sea but it has also been recorded in fjords and shelf. It occurs where the mean sea floor organic C flux is $\sim 5 \mathrm{~g} \mathrm{~m}^{2} \mathrm{a}^{-1}$ (Altenbach et al., 1999). Pullenia subsphaerica described from Antarctica looks very similar and may be a synonym.

Pullenia elegans. This is like quinqueloba but with 7 chambers in the final whorl. It is known only from the shelf off California, USA (Lankford \& Phleger, 1973).

Pullenia osloensis. This is quite distinct being much smaller than bulloides and less spherical. It was described from the Quaternary of southern Norway. Most records are from fjords and shelf adjacent to Norway and the Barents Sea with just a few individuals recorded from the Weddell Sea so the distribution is disjunct (Fig. 82) but no molecular genetic studies have yet been carried out so it is not known whether it is a single or two species. In the Arctic Ocean it occurs in seasonally ice-free areas (Wollenburg \& Mackensen, 1998). In a two-year experiment, where the fauna was deprived of fresh phytodetritus, it decreased in abundance perhaps showing its need for fresh food (Alve, 2010).
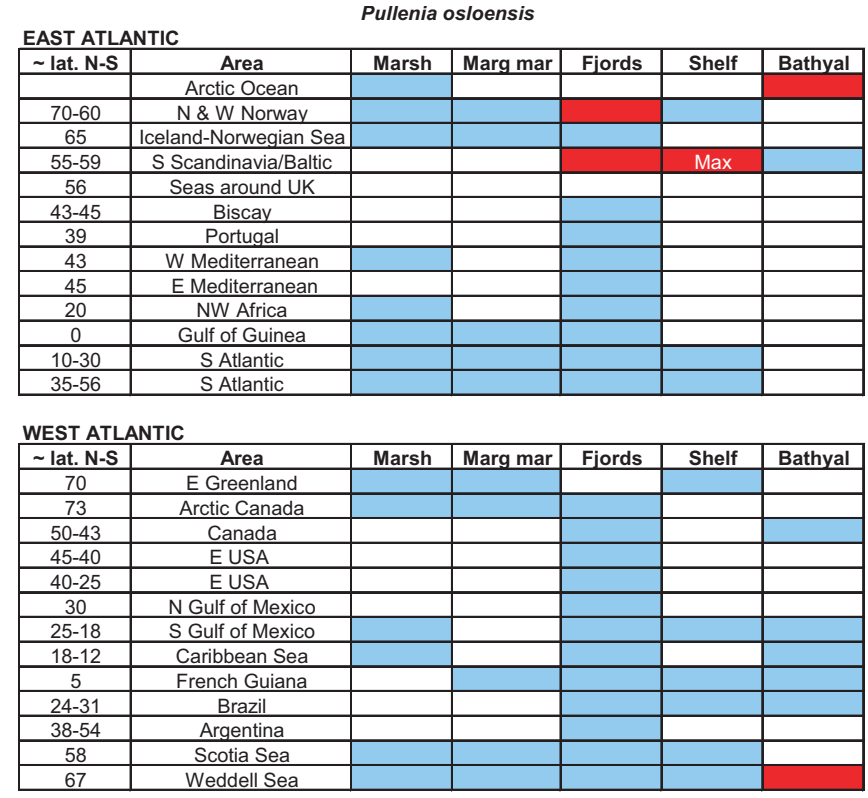

Fig. 82. Pullenia osloensis.

Pullenia quinqueloba. Most records are from the Atlantic Ocean but it is also present in the Pacific and rarely in the Indian Ocean (Fig. 83). It occurs where the mean sea floor organic C flux is $\sim 5 \mathrm{~g} \mathrm{~m}^{2} \mathrm{a}^{-1}$ (Altenbach et al., 1999).

Pullenia salisburyi. This has 6 chambers in the final whorl and is said to be more compressed than quinqueloba. It is exclusively deep sea with rare occurrences in the South Atlantic, Pacific USA (where it is more common) and South China Sea.

Pullenia simplex. Not widely distributed (Portugal, South Atlantic, Scotia and Weddell seas) with maximum abundances of $25 \%$ Portugal and $24 \%$ Weddell Sea. It is said to differ from quinqueloba by its more rounded test but the two may be conspecific.

Pullenia subcarinata. The type looks more like Melonis than Pullenia. It is primarily a deep-sea form (82\%) with some shelf and fjord records. It occurs in the Atlantic and Pacific oceans (Fig. 84). In the South Atlantic it is present beneath surface waters showing seasonally varying productivity (Mackensen et al., 1995). It is infaunal with $\mathrm{ALD}_{8} 2.6 \mathrm{~cm}$ in Sea of Okhotsk (Bubenshchikova et al., 2008).

Reussella. Only two species are commonly recorded: atlantica and spinulosa with 84 and 223 occurrences, respectively. The former was originally described as a variety of the latter, differing in being smaller, more slender, thinner walled and with a tendency for the adult chambers to decrease in diameter. Rarer forms include aculeata and pacifica (Tables 2,3) but often the forms are left in open nomenclature so the biogeographical plot is given for all species (Fig. 85). The genus is known primarily from the shelf, with atlantica also being common in marginal marine environments especially in the Caribbean and it is confined to the Atlantic and Gulf of Mexico. The most commonly reported form is $R$. spinulosa: from shelf seas in the Adriatic, east USA, Puerto Rico, Japan and Scilly atoll (Pacific). The three abundances $>10 \%$ 
Pullenia quinqueloba

EAST ATLANTIC
\begin{tabular}{|c|c|c|c|c|c|c|}
\hline$\sim$ lat. N-S & Area & Marsh & Marg mar & Fjords & Shelf & Deep sea \\
\hline & Arctic Ocean & & & & & \\
\hline $70-60$ & N \& W Norway & & & & & \\
\hline 65 & Iceland-Norwegian Sea & & & & & \\
\hline $55-59$ & S Scandinavia/Baltic & & & & & \\
\hline 56 & Seas around UK & & & & & \\
\hline $43-45$ & Biscay & & & & & \\
\hline 39 & Portugal & & & & & \\
\hline 43 & W Mediterranean & & & & & \\
\hline 45 & E Mediterranean & & & & & \\
\hline 20 & NW Africa & & & & & Max \\
\hline 0 & Gulf of Guinea & & & & & \\
\hline $10-30$ & S Atlantic & & & & & \\
\hline $35-56$ & S Atlantic & & & & & \\
\hline
\end{tabular}

WEST ATLANTIC
\begin{tabular}{|c|c|c|c|c|c|c|}
\hline$\sim$ lat. N-S & Area & Marsh & Marg mar & Fjords & Shelf & Deep sea \\
\hline 70 & E Greenland & & & & & \\
\hline 73 & Arctic Canada & & & & & \\
\hline $50-43$ & Canada & & & & & \\
\hline $45-40$ & E USA & & & & & \\
\hline $40-25$ & E USA & & & & & \\
\hline 30 & N Gulf of Mexico & & & & & \\
\hline $25-18$ & S Gulf of Mexico & & & & & \\
\hline $18-12$ & Caribbean Sea & & & & & \\
\hline 5 & French Guiana & & & & & \\
\hline $24-31$ & Brazil & & & & & \\
\hline $38-54$ & Argentina & & & & & \\
\hline 58 & Scotia Sea & & & & & $\mathrm{x}$ \\
\hline 67 & Weddell Sea & & & & & \\
\hline
\end{tabular}

REST OF WORLD
\begin{tabular}{|c|c|c|c|c|c|c|}
\hline$\sim$ lat. & Area & Marsh & Marg mar & Fjords & Shelf & Deep sea \\
\hline 48 & Pacific Canada & & & & & \\
\hline $47-33$ & Pacific USA & & & & & \\
\hline 28 & Baja California & & & & & \\
\hline 12 & El Salvador-Nicaragua & & & & & \\
\hline 35 & Korea \& Japan & & & & & \\
\hline $\mathrm{x}$ & S China Sea & & & & $\mathrm{x}$ & $\mathrm{X}$ \\
\hline 5 & Banda Sea & & & & & \\
\hline 40 & New Zealand & & & & & \\
\hline 18 & Atolls & & & & & \\
\hline & Red Sea/Arabian Gulf & & & & & \\
\hline 10 & Indian Ocean & & & & & $\mathrm{x}$ \\
\hline 28 & S Africa & & & & & \\
\hline $15-30$ & Australia & & & & & \\
\hline 65 & Antarctic & & & & & \\
\hline
\end{tabular}

Fig. 83. Pullenia quinqueloba.

are from the Adriatic and Scilly atoll. It may be epiphytic with slight tolerance of increased salinities and to oxygen deficiency (Van der Zwaan, 1982). It is also considered to be epiphytic in the Adriatic (Donnici \& Serandrei Barbero, 2002). The main occurrence of $R$. aculeata is on the Mediterranean shelf off Spain (with a single record from a lagoon), Japan and the Red Sea. The few records of $R$. pacifica are from Baja California, Gulf of California and Japan. Reussella appears to favour temperate to warm fully marine environments.

Robertina/Robertinoides. Höglund (1947) separated Robertinoides from Robertina on the basis of subtle differences in the apertures and the internal partitions. Only two species are commonly recorded (arctica and charlottensis) and many records are left in open nomenclature. Robertina/Robertinoides occur mainly in the deep sea and shelf with few records from fjords and marginal marine environments (Fig. 86). They span the Arctic, Atlantic, Mediterranean, Pacific and Southern oceans. Overall they appear to favour cooler waters.

Robertina arctica. This is the most common form occurring in marginal marine, fjord, shelf and deep-sea environments of the North Atlantic, Mediterranean and Arctic oceans (Fig. 87).
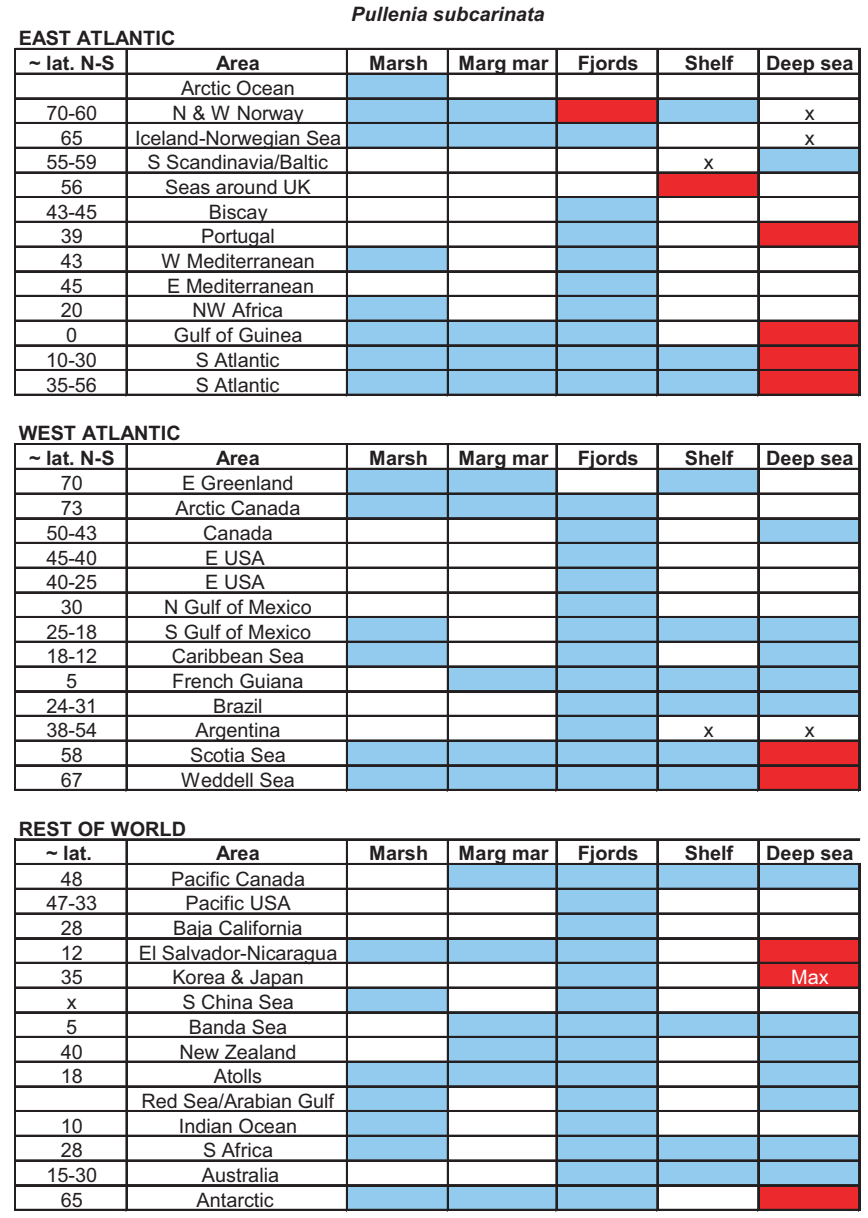

Fig. 84. Pullenia subcarinata.

Robertinoides charlottensis. This is confined to shelf and deep sea off Greenland, Grand Banks and eastern and western USA and Japan (Fig. 88).

Siphonina. Five species have been recorded in 76 samples and each occurs infrequently so the entire group is very rare. None occurs in marsh or fjord environments but all occur in shelf seas. Siphonina pulchra and $S$. tubulosa also occur in marginal marine environments (only in the Caribbean). Siphonina bradyana occurs mainly in the deep sea and $S$. pulchra has a single deep-sea occurrence at $253 \mathrm{~m}$ in the Gulf of Guinea. All occurrences are in the Atlantic Ocean, Mediterranean or Caribbean except for three deep-sea occurrences in the South China Sea (Fig. 89).

Sphaeroidina bulloides. This deep-sea species occurs in the East Atlantic and the Scotia Sea, in the Mediterranean and in the South China Sea (Fig. 90). It occurs where the mean sea floor organic C flux is $7 \mathrm{~g} \mathrm{~m}^{2} \mathrm{a}^{-1}$ (Altenbach et al., 1999). The range tolerated in the Gulf of Guinea is $0.9-22 \mathrm{~g} \mathrm{~m}^{2} \mathrm{a}^{-1}$ (Altenbach et al., 2003).

Spirillina vivipara. This is an easily identified species with little scope for error. It has a wide distribution from marsh to deep sea but the majority of records are from the shelf $(76 \%)$. It occurs in 
Reussella spp.

EAST ATLANTIC
\begin{tabular}{|c|c|c|c|c|c|c|}
\hline$\sim$ lat. N-S & Area & Marsh & Marg mar & Fjords & Shelf & Deep sea \\
\hline & Arctic Ocean & & & & & \\
\hline $70-60$ & N \& W Norway & & & & & \\
\hline 65 & Iceland-Norwegian Sea & & & & & \\
\hline $55-59$ & S Scandinavia/Baltic & & & & & \\
\hline 56 & Seas around UK & & & & & \\
\hline $43-45$ & Biscay & & & & & \\
\hline 39 & Portugal & & & & & \\
\hline 43 & W Mediterranean & & $x$ & & Max & \\
\hline 45 & E Mediterranean & & & & & \\
\hline 20 & NW Africa & & & & & \\
\hline 0 & Gulf of Guinea & & & & & \\
\hline $10-30$ & S Atlantic & & & & & \\
\hline $35-56$ & S Atlantic & & & & & \\
\hline
\end{tabular}

WEST ATLANTIC
\begin{tabular}{|c|c|c|c|c|c|c|}
\hline$\sim$ lat. N-S & Area & Marsh & Marg mar & Fjords & Shelf & Deep sea \\
\hline 70 & E Greenland & & & & & \\
\hline 73 & Arctic Canada & & & & & \\
\hline $50-43$ & Canada & & & & & \\
\hline $45-40$ & E USA & & & & & \\
\hline $40-25$ & E USA & & & & & \\
\hline 30 & N Gulf of Mexico & & & & & \\
\hline $25-18$ & S Gulf of Mexico & & & & & \\
\hline $18-12$ & Caribbean Sea & & & & & \\
\hline 5 & French Guiana & & & & & \\
\hline $24-31$ & Brazil & & & & & \\
\hline $38-54$ & Argentina & & & & & \\
\hline 58 & Scotia Sea & & & & & \\
\hline 67 & Weddell Sea & & & & & \\
\hline
\end{tabular}

\section{REST OF WORLD}

REST OF WORLD
\begin{tabular}{|c|c|c|c|c|c|c|}
\hline$\sim$ lat. & Area & Marsh & Marg mar & Fjords & Shelf & Deep sea \\
\hline 48 & Pacific Canada & & & & & \\
\hline $47-33$ & Pacific USA & & & & & \\
\hline 28 & Baja California & & $x$ & & & \\
\hline 12 & El Salvador-Nicaragua & & & & & \\
\hline 35 & Korea \& Japan & & & & & \\
\hline $\mathrm{x}$ & S China Sea & & & & $\mathrm{x}$ & \\
\hline 5 & Banda Sea & & & & & \\
\hline 40 & New Zealand & & & & & \\
\hline 18 & Atolls & & & & Max & \\
\hline & Red Sea/Arabian Gulf & & & & $\mathrm{x}$ & \\
\hline 10 & Indian Ocean & & & & $\mathrm{x}$ & \\
\hline 28 & S Africa & & & & & \\
\hline $15-30$ & Australia & & & & & \\
\hline 65 & Antarctic & & & & & \\
\hline
\end{tabular}

Fig. 85. Reussella spp.

the Atlantic, Mediterranean, Pacific and Indian oceans but is absent from polar regions (Fig. 91). It is recorded down to 1010 $\mathrm{m}$ off Portugal, $247 \mathrm{~m}$ in the Gulf of Guinea, $290 \mathrm{~m}$ off Japan and $902 \mathrm{~m}$ in the Arabian Sea. Its maximum abundance (89\%) is on a marsh (Georgia, USA) but it is also abundant on carbonate sediments off New Caledonia, Algeria and southern England. It is epiphytic off Western Australia (Semeniuk, 2001). In a ria in northern Spain in high energy coarse sediments it is locally common down to $9 \mathrm{~cm}$ (Diz et al., 2004). The mode of life is attached mobile: clinging to stable substrates using pseudopodia but also able to move freely through the sediment (Sturrock \& Murray, 1981). The reproductive cycle was determined by Myers (1936). It is dimorphic and, under experimental conditions, the optimum temperature is $21^{\circ} \mathrm{C}$ with a minimum of 18 days to complete the full life cycle. At $>26^{\circ} \mathrm{C}$ there is degeneration of some or all of the young while at $18^{\circ} \mathrm{C}$ the rate of reproduction is much reduced.

Stainforthia concava. The types are from Gullmar fjord, Sweden, where it was described as 'sparsely distributed' (Höglund, 1947, p. 258). It is now known to occur in a fjord on Svalbard and in shelf sediments from Iceland, Celtic Sea to the Gulf of Guinea including the western Mediterranean and Adriatic, the continental slope from Biscay to the Gulf of Guinea. There are isolated
Robertina and Robertinoides all spp.
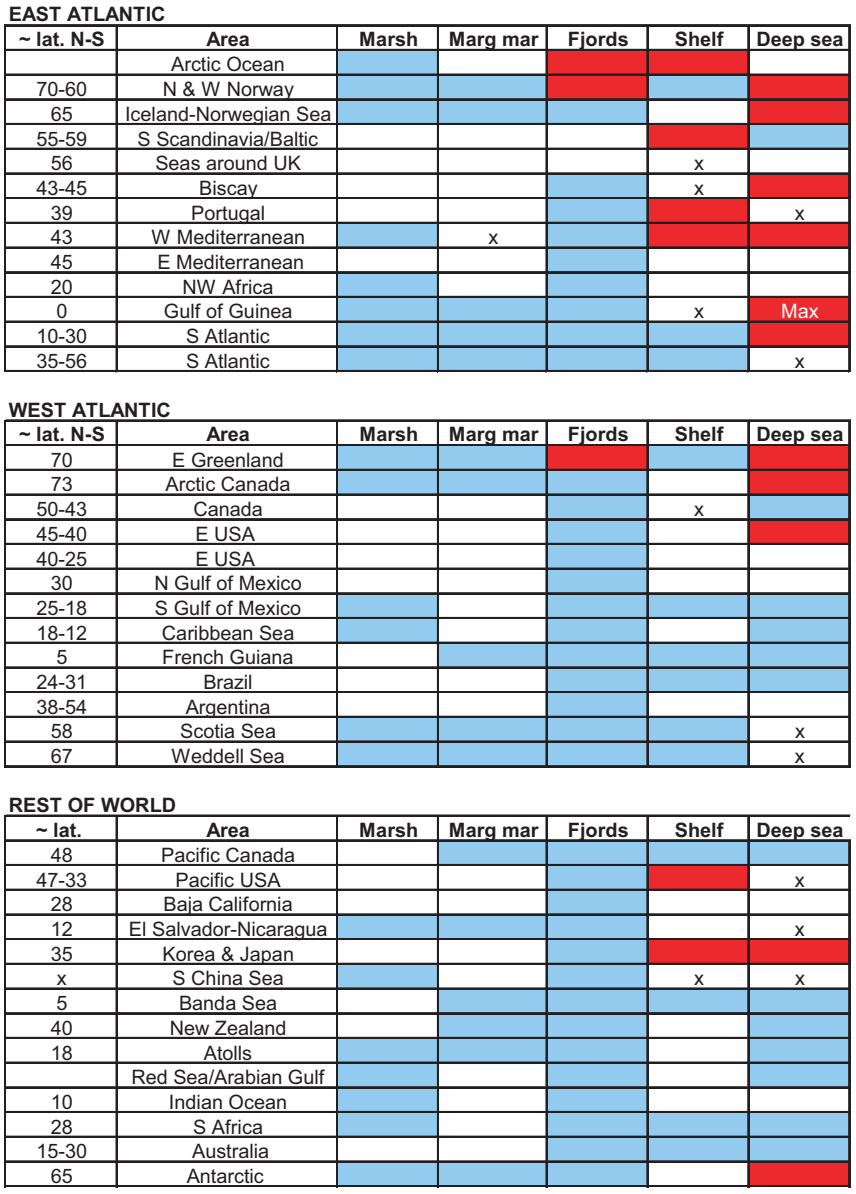

Fig. 86. Robertina/Robertinoides spp..
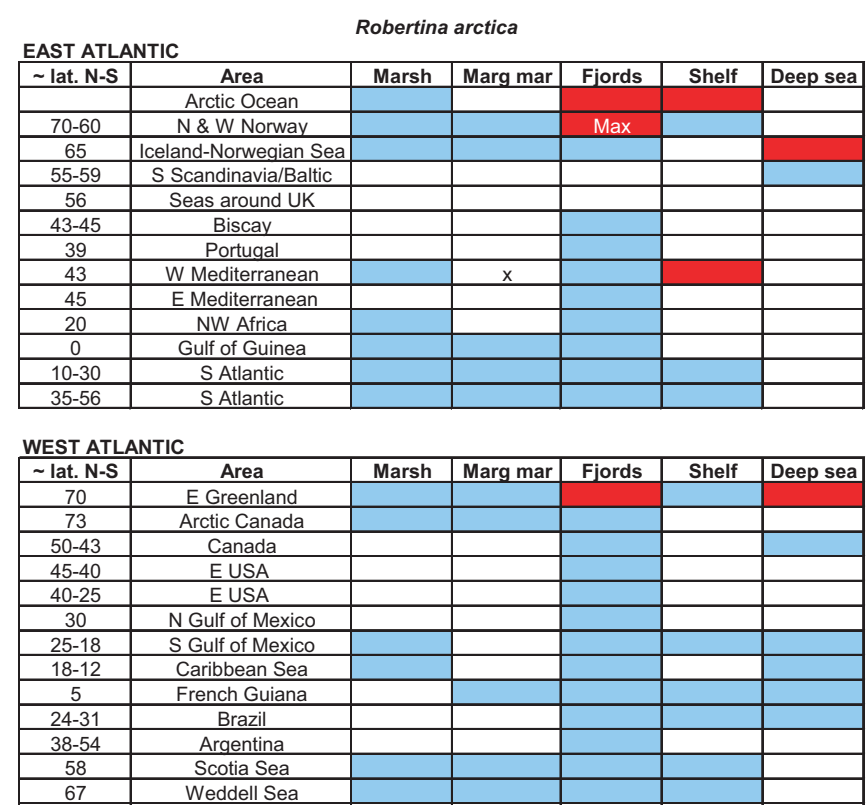

Fig. 87. Robertina arctica. 
Robertinoides charlottensis

WEST ATLANTIC
\begin{tabular}{|c|c|c|c|c|c|c|}
\hline$\sim$ lat. N-S & Area & Marsh & Marg mar & Fjords & Shelf & Deep sea \\
\hline 70 & E Greenland & & & & & \\
\hline 73 & Arctic Canada & & & & & \\
\hline $50-43$ & Canada & & & & $x$ & \\
\hline $45-40$ & E USA & & & & & \\
\hline $40-25$ & E USA & & & & & \\
\hline 30 & N Gulf of Mexico & & & & & \\
\hline $25-18$ & S Gulf of Mexico & & & & & \\
\hline $18-12$ & Caribbean Sea & & & & & \\
\hline 5 & French Guiana & & & & & \\
\hline $24-31$ & Brazil & & & & & \\
\hline $38-54$ & Argentina & & & & & \\
\hline 58 & Scotia Sea & & & & & \\
\hline 67 & Weddell Sea & & & & & \\
\hline
\end{tabular}

\section{REST OF WORLD}

\begin{tabular}{|c|c|c|c|c|c|c|}
\hline$\sim$ lat. & Area & Marsh & Marg mar & Fjords & Shelf & Deep sea \\
\hline 48 & Pacific Canada & & & & & \\
\hline $47-33$ & Pacific USA & & & & & X \\
\hline 28 & Baja California & & & & & \\
\hline 12 & El Salvador-Nicaragua & & & & & \\
\hline 35 & Korea \& Japan & & & & & Max \\
\hline $\mathrm{X}$ & S China Sea & & & & & \\
\hline 5 & Banda Sea & & & & & \\
\hline 40 & New Zealand & & & & & \\
\hline 18 & Atolls & & & & & \\
\hline & Red Sea/Arabian Gulf & & & & & \\
\hline 10 & Indian Ocean & & & & & \\
\hline 28 & S Africa & & & & & \\
\hline $15-30$ & Australia & & & & & \\
\hline 65 & Antarctic & & & & & \\
\hline
\end{tabular}

Fig. 88. Robertinoides charlottensis.

Siphonina spp.

EAST ATLANTIC
\begin{tabular}{|c|c|c|c|c|c|c|}
\hline$\sim$ lat. N-S & Area & Marsh & Marg mar & Fjords & Shelf & Deep sea \\
\hline & Arctic Ocean & & & & & \\
\hline $70-60$ & N \& W Norway & & & & & \\
\hline 65 & Iceland-Norwegian Sea & & & & & \\
\hline $55-59$ & S Scandinavia/Baltic & & & & & \\
\hline 56 & Seas around UK & & & & $x$ & \\
\hline $43-45$ & Biscay & & & & & \\
\hline 39 & Portugal & & & & & \\
\hline 43 & W Mediterranean & & & & & $\times$ \\
\hline 45 & E Mediterranean & & & & $x$ & \\
\hline 20 & NW Africa & & & & & \\
\hline 0 & Gulf of Guinea & & & & & $\times$ \\
\hline $10-30$ & S Atlantic & & & & & \\
\hline $35-56$ & S Atlantic & & & & & \\
\hline
\end{tabular}

WEST ATLANTIC
\begin{tabular}{|c|c|c|c|c|c|c|}
\hline$\sim$ lat. N-S & Area & Marsh & Marg mar & Fjords & Shelf & Deep sea \\
\hline 70 & E Greenland & & & & & \\
\hline 73 & Arctic Canada & & & & & \\
\hline $50-43$ & Canada & & & & & \\
\hline $45-40$ & E USA & & & & & \\
\hline $40-25$ & E USA & & & & & \\
\hline 30 & N Gulf of Mexico & & & & & \\
\hline $25-18$ & S Gulf of Mexico & & & & & \\
\hline $18-12$ & Caribbean Sea & & Max & & X & \\
\hline 5 & French Guiana & & & & & \\
\hline $24-31$ & Brazil & & & & & \\
\hline $38-54$ & Argentina & & & & & \\
\hline 58 & Scotia Sea & & & & & \\
\hline 67 & Weddell Sea & & & & & \\
\hline
\end{tabular}

REST OF WORLD
\begin{tabular}{|c|c|c|c|c|c|c|}
\hline$\sim$ lat. & Area & Marsh & Marg mar & Fjords & Shelf & Deep sea \\
\hline 48 & Pacific Canada & & & & & \\
\hline $47-33$ & Pacific USA & & & & & \\
\hline 28 & Baja California & & & & & \\
\hline 12 & El Salvador-Nicaragua & & & & & \\
\hline 35 & Korea \& Japan & & & & & \\
\hline $\mathrm{X}$ & S China Sea & & & & $\mathrm{x}$ & \\
\hline 5 & Banda Sea & & & & & \\
\hline 40 & New Zealand & & & & & \\
\hline 18 & Atolls & & & & & \\
\hline & Red Sea/Arabian Gulf & & & & & \\
\hline 10 & Indian Ocean & & & & & \\
\hline 28 & S Africa & & & & & \\
\hline $15-30$ & Australia & & & & & \\
\hline 65 & Antarctic & & & & & \\
\hline
\end{tabular}

Fig. 89. Siphonina spp.
Sphaeroidina bulloides

EAST ATLANTIC
\begin{tabular}{|c|c|c|c|c|c|c|}
\hline$\sim$ lat. N-S & Area & Marsh & Marg mar & Fjords & Shelf & Deep sea \\
\hline & Arctic Ocean & & & & & \\
\hline $70-60$ & N \& W Norway & & & & & \\
\hline 65 & Iceland-Norwegian Sea & & & & & \\
\hline $55-59$ & S Scandinavia/Baltic & & & & & \\
\hline 56 & Seas around UK & & & & & \\
\hline $43-45$ & Biscay & & & & & X \\
\hline 39 & Portugal & & & & & \\
\hline 43 & W Mediterranean & & & & & \\
\hline 45 & E Mediterranean & & & & & \\
\hline 20 & NW Africa & & & & & \\
\hline 0 & Gulf of Guinea & & & & & \\
\hline $10-30$ & S Atlantic & & & & & \\
\hline $35-56$ & S Atlantic & & & & & \\
\hline
\end{tabular}

WEST ATLANTIC
\begin{tabular}{|c|c|c|c|c|c|c|}
\hline$\sim$ lat. N-S & Area & Marsh & Marg mar & Fjords & Shelf & Deep sea \\
\hline 70 & E Greenland & & & & & \\
\hline 73 & Arctic Canada & & & & & \\
\hline $50-43$ & Canada & & & & & \\
\hline $45-40$ & E USA & & & & & \\
\hline $40-25$ & E USA & & & & & \\
\hline 30 & N Gulf of Mexico & & & & & \\
\hline $25-18$ & S Gulf of Mexico & & & & & \\
\hline $18-12$ & Caribbean Sea & & & & & \\
\hline 5 & French Guiana & & & & & \\
\hline $24-31$ & Brazil & & & & & \\
\hline $38-54$ & Argentina & & & & & \\
\hline 58 & Scotia Sea & & & & & \\
\hline 67 & Weddell Sea & & & & & \\
\hline
\end{tabular}

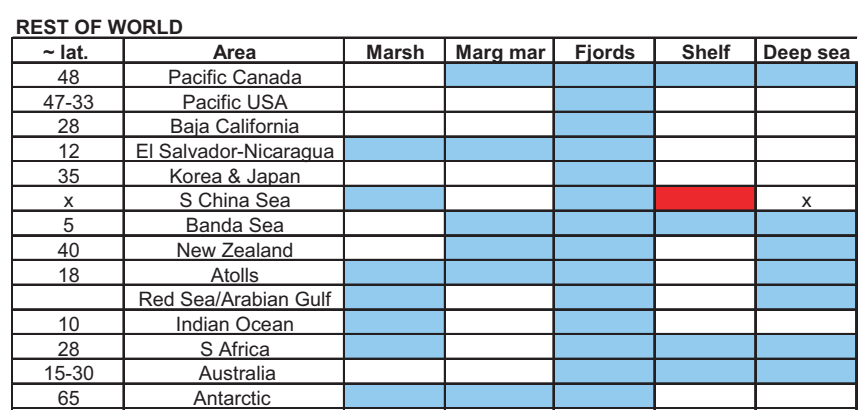

Fig. 90. Sphaeroidina bulloides.

occurrences on the Canadian Arctic shelf, and continental slope off Iceland, tropical eastern Atlantic and Nicaragua; also a single record from a lagoon (Arcachon, France) (Fig. 92). Overall, the abundance is low with a single high value on the shelf off Algeria where it occurs at $67 \mathrm{~m}$ in coarse0grained cool-water carbonate sediment.

Stainforthia fusiformis. This is the most commonly occurring species of Stainforthia. Because of its small size it is more reliably recorded in $>63 \mu \mathrm{m}$ assemblages than in coarser fractions. It occurs from marginal marine to deep sea but is absent from marshes (Fig. 93). In marginal marine settings it is present in muddy sediments in the slightly brackish areas of estuaries and lagoons off NW Europe and the eastern seaboard of the USA. Although it occurs in Swedish and Norwegian fjords, it is in the latter that it reaches high abundance with mean values $>40 \%$ and maximum occurrences of $88-98 \%$. In shelf seas it extends from NW Europe to the Gulf of Guinea and in some areas reaches abundances $>70 \%$ (Skagerrak, central North Sea, English Channel, Celtic Sea) and $>65 \%$ off NW Africa. It occurs off southern France and in the Adriatic. In the NW Atlantic it occurs from the Arctic as far south as Cape Hatteras, USA. In the deep sea it is present in small numbers not only in the North Atlantic but also in the South China Sea, the Arabian Sea (Indian Ocean) and the 

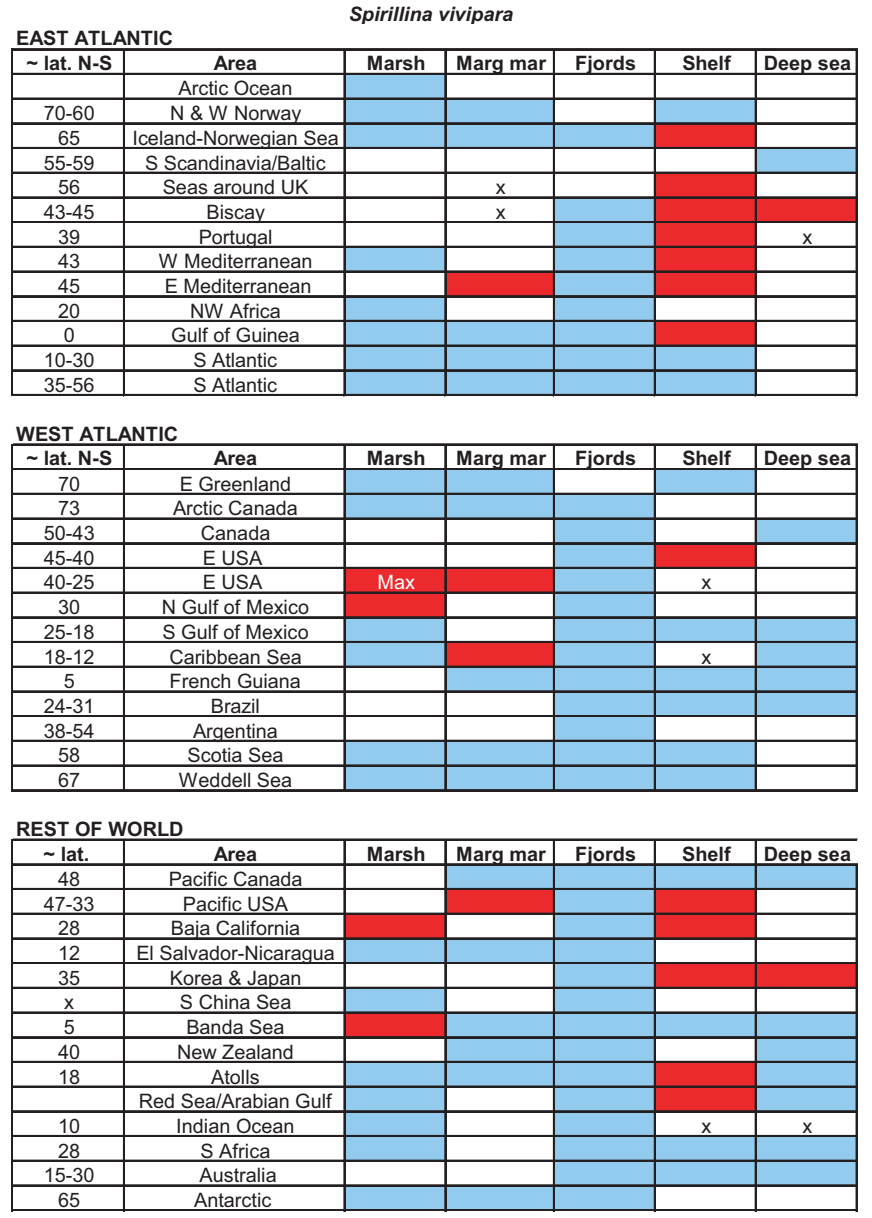

Fig. 91. Spirillina vivipara.

Scotia and Ross seas off Antarctica. It has not yet been recorded from the Pacific.

In the North Sea it may reproduce throughout the year (Murray, 1992). This species lives infaunally. In the southern North Sea on medium to fine sand substrates it occurs down to $25 \mathrm{~cm}$ but the majority of occurrences are at $<5 \mathrm{~cm}$ (Moodley, 1990). In the Adriatic it is restricted to the top $2 \mathrm{~cm}$ (Barmawidjaja et al., 1992).

This is an opportunistic species which is able to live at salinities $>28$, in sulphidic oxygen-depleted sediments $\left(<2 \mathrm{ml}^{-1} \mathrm{O}_{2}\right)$ rich in organic matter (Alve, 1990; 1994; 1995; 2003; Bernhard \& Bowser, 1999; Mojtahid et al., 2009). In a two-year experiment, where the fauna was deprived of fresh phytodetritus, S. fusiformis decreased in abundance (Alve, 2010). It was a very successful colonizer in experiments (Alve, 1999). It migrated vertically from an initial maximum of $0.5-2 \mathrm{~cm}$ to the top $0.5 \mathrm{~cm}$ and even epifaunally on to worm tubes in response to experimentally altered oxygen conditions and did not tolerate oxygen levels $<0.2 \mathrm{ml} \mathrm{l}^{-1}$ (Alve \& Bernhard, 1995). It is able to inhabit stressed environments subject to natural disturbance and it may also be able to do so where the disturbance is due to trawling (Alve \& Murray, 1997). In a review, Alve (2003) concluded that it occupies three very different settings: beneath hydrographic fronts, e.g. Celtic Sea and Skagerrak; physically disturbed sediments, e.g. heavily
Stainforthia concava

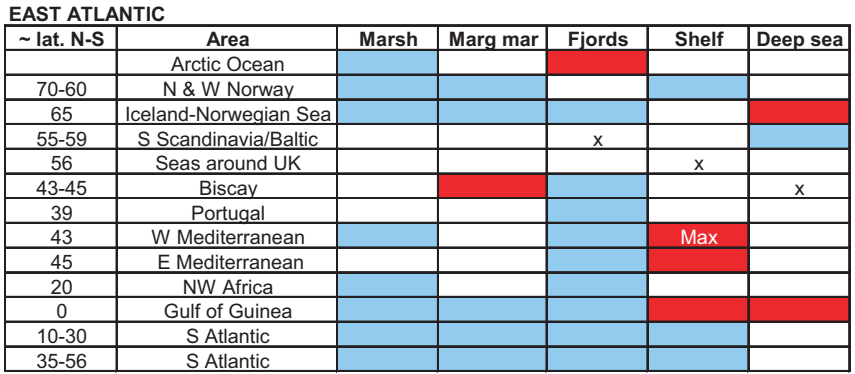

\section{WEST ATLANTIC}

\begin{tabular}{|c|c|c|c|c|c|c|}
\hline$\sim$ lat. N-S & Area & Marsh & Marg mar & Fjords & Shelf & Deep sea \\
\hline 70 & E Greenland & & & & & \\
\hline 73 & Arctic Canada & & & & X & \\
\hline $50-43$ & Canada & & & & & \\
\hline $45-40$ & E USA & & & & & \\
\hline $40-25$ & E USA & & & & & \\
\hline 30 & N Gulf of Mexico & & & & & \\
\hline $25-18$ & S Gulf of Mexico & & & & & \\
\hline $18-12$ & Caribbean Sea & & & & & \\
\hline 5 & French Guiana & & & & & \\
\hline $24-31$ & Brazil & & & & & \\
\hline $38-54$ & Argentina & & & & & \\
\hline 58 & Scotia Sea & & & & & \\
\hline 67 & Weddell Sea & & & & & \\
\hline
\end{tabular}

\section{REST OF WORLD}

\begin{tabular}{|c|c|c|c|c|c|c|}
\hline$\sim$ lat. & Area & Marsh & Marg mar & Fjords & Shelf & Deep sea \\
\hline 48 & Pacific Canada & & & & & \\
\hline $47-33$ & Pacific USA & & & & & \\
\hline 28 & Baja California & & & & & \\
\hline 12 & El Salvador-Nicaraqua & & & & & $x$ \\
\hline 35 & Korea \& Japan & & & & & \\
\hline $\mathrm{x}$ & S China Sea & & & & & \\
\hline 5 & Banda Sea & & & & & \\
\hline 40 & New Zealand & & & & & \\
\hline 18 & Atolls & & & & & \\
\hline & Red Sea/Arabian Gulf & & & & & \\
\hline 10 & Indian Ocean & & & & & \\
\hline 28 & S Africa & & & & & \\
\hline $15-30$ & Australia & & & & & \\
\hline 65 & Antarctic & & & & & \\
\hline
\end{tabular}

Fig. 92. Stainforthia concava.

trawled North Sea and areas where sewage is dumped; ephemerally dysoxic/anoxic basins, e.g. fjords. It is the ability to cope with environmental stress rather than the control of any single environmental parameter that enables it to predominate in these areas.

Stainforthia loeblichi. This species was distinguished from $S$. concava because it is 'somewhat larger and by the lack of a distinct apical spine'; however, Feyling-Hanssen (1964, p. 308) considered the possibility that the two species may be the same. The types are from the Late Quaternary of the Oslo area, Norway. Although this species has a restricted distribution in cool waters in the Northern Hemisphere, from fjord, shelf and continental slope of the Arctic Ocean to western Norway $(433 \mathrm{~m})$ and the Grand Banks off Canada $(330 \mathrm{~m})$, it has moderate abundance in several areas. In two northern fjords on Svalbard abundances $>10 \%$ occur in basins with water temperatures of 1.4 to $-0.3^{\circ} \mathrm{C}$ but the only factor showing good correlation with abundance is salinity (34.66, Hald \& Korsun, 1997). In subarctic Malangan fjord, Norway, a single occurrence $>10 \%$ occurs in the inner part in waters of 6.0 to $6.9^{\circ} \mathrm{C}$ and salinity 34-34.75 (Husum \& Hald, 2004). On the Grand Banks it occurs in water with a temperature of $\sim 4^{\circ} \mathrm{C}$ with a highest abundance of $33 \%$ (Sen Gupta, 1971). 
Stainforthia fusiformis

EAST ATLANTIC
\begin{tabular}{|c|c|c|c|c|c|c|}
\hline$\sim$ lat. N-S & Area & Marsh & Marg mar & Fjords & Shelf & Deep sea \\
\hline & Arctic Ocean & & & & & \\
\hline $70-60$ & N \& W Norway & & & & & \\
\hline 65 & Iceland-Norwegian Sea & & & & & $\mathrm{X}$ \\
\hline $55-59$ & S Scandinavia/Baltic & & & Max & & \\
\hline 56 & Seas around UK & & & & & \\
\hline $43-45$ & Biscay & & & & & $\times$ \\
\hline 39 & Portugal & & & & & $\mathrm{X}$ \\
\hline 43 & W Mediterranean & & & & & \\
\hline 45 & E Mediterranean & & & & & \\
\hline 20 & NW Africa & & & & & \\
\hline 0 & Gulf of Guinea & & & & & \\
\hline $10-30$ & S Atlantic & & & & & \\
\hline $35-56$ & S Atlantic & & & & & \\
\hline
\end{tabular}

WEST ATLANTIC
\begin{tabular}{|c|c|c|c|c|c|c|}
\hline$\sim$ lat. N-S & Area & Marsh & Marg mar & Fjords & Shelf & Deep sea \\
\hline 70 & E Greenland & & & & & \\
\hline 73 & Arctic Canada & & & & & \\
\hline $50-43$ & Canada & & & & & \\
\hline $45-40$ & E USA & & & & & \\
\hline $40-25$ & E USA & & & & & $x$ \\
\hline 30 & N Gulf of Mexico & & & & & \\
\hline $25-18$ & S Gulf of Mexico & & & & & \\
\hline $18-12$ & Caribbean Sea & & & & & \\
\hline 5 & French Guiana & & & & & \\
\hline $24-31$ & Brazil & & & & & \\
\hline $38-54$ & Argentina & & & & & \\
\hline 58 & Scotia Sea & & & & & \\
\hline 67 & Weddell Sea & & & & & \\
\hline
\end{tabular}

REST OF WORLD
\begin{tabular}{|c|c|c|c|c|c|c|}
\hline$\sim$ lat. & Area & Marsh & Marg mar & Fjords & Shelf & Deep sea \\
\hline 48 & Pacific Canada & & & & & \\
\hline $47-33$ & Pacific USA & & & & & \\
\hline 28 & Baja California & & & & & \\
\hline 12 & El Salvador-Nicaragua & & & & & \\
\hline 35 & Korea \& Japan & & & & & \\
\hline $\mathrm{X}$ & S China Sea & & & & & $\mathrm{X}$ \\
\hline 5 & Banda Sea & & & & & \\
\hline 40 & New Zealand & & & & & \\
\hline 18 & Atolls & & & & & \\
\hline & Red Sea/Arabian Gulf & & & & & \\
\hline 10 & Indian Ocean & & & & & $\mathrm{x}$ \\
\hline 28 & S Africa & & & & & \\
\hline $15-30$ & Australia & & & & & \\
\hline 65 & Antarctic & & & & & \\
\hline
\end{tabular}

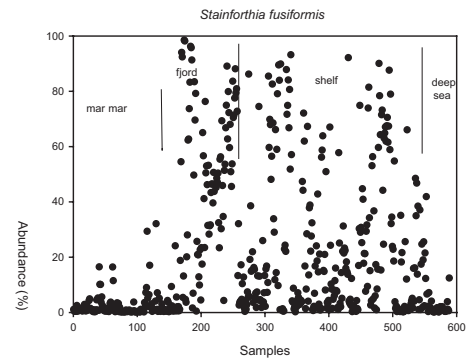

Fig. 93. Stainforthia fusiformis.

In the Barents Sea it reaches $12 \%$ on the continental slope at 433 $\mathrm{m}$ and with a TOC flux of $21 \mathrm{mg} \mathrm{C} \mathrm{m}^{-2} \mathrm{~d}^{-1}$ (Ivanova et al., 2008). Thus, the distribution of $S$. loeblichi is geographically more confined than that of $S$. concava and it seems to be restricted to somewhat cooler waters. There is no information on downcore occurrence but is likely to be infaunal.

Trifarina angulosa. Although there are occasional occurrences in marginal marine and fjord settings this is essentially a shelf and upper slope species and that is where it has its highest mean and maximum abundances ( $12 \%$ and $76 \%$, respectively). It is found in all oceans except the Indian Ocean (Fig. 94). It is epifaunal and favours shelf break areas where the sediment is sand to gravel under the influence of bottom currents
Trifarina angulosa
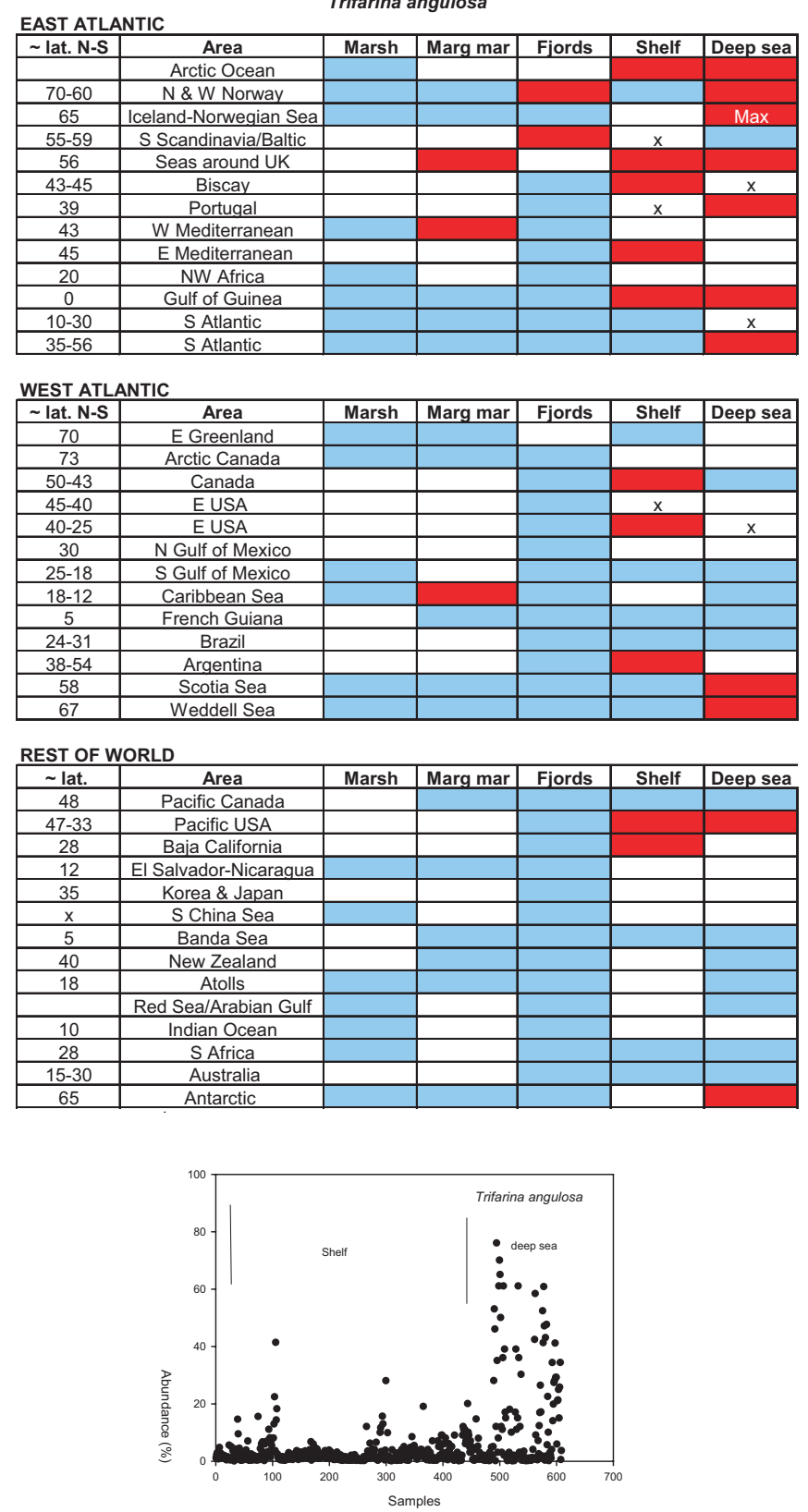

Fig. 94. Trifarina angulosa.

(Mackensen et al., 1993; 1995; Harloff \& Mackensen, 1997) and oxic conditions (Schönfeld, 2001). The flux rate of organic carbon tolerated in the Gulf of Guinea is $8.7-89.2 \mathrm{~g} \mathrm{~m}^{2} \mathrm{a}^{-1}$ (Altenbach et al., 2003).

Trifarina fluens. The types are from Alaska and are said to differ from $T$. angulosa in having a more ornamented test, more irregular and inflated later chambers and not being consistently triangular in cross-section. There are 74 records compared with 621 for T. angulosa. All occurrences are from the Arctic Ocean and northern North Atlantic, from fjords, shelf and deep sea. It reaches its maximum abundance in the Norwegian Sea (Fig. 95). It is clearly a cold-water species. 


Trifarina fluens
EAST ATLANTIC
\begin{tabular}{|c|c|c|l|l|c|c|}
\hline$\sim$ lat. N-S & Area & Marsh & Marg mar & Fjords & Shelf & Deep sea \\
\hline & Arctic Ocean & & & & & \\
\hline $70-60$ & N \& W Norway & & & & & Max \\
\hline 65 & Iceland-Norwegian Sea & & & & & Max \\
\hline $55-59$ & S Scandinavia/Baltic & & & & & \\
\hline 56 & Seas around UK & & & & & \\
\hline $43-45$ & Biscay & & & & & \\
\hline 39 & Portugal & & & & & \\
\hline 43 & W Mediterranean & & & & & \\
\hline 45 & E Mediterranean & & & & & \\
\hline 20 & NW Africa & & & & & \\
\hline 0 & Gulf of Guinea & & & & & \\
\hline $10-30$ & S Atlantic & & & & & \\
\hline $35-56$ & S Atlantic & & & & & \\
\hline
\end{tabular}

\section{WEST ATLANTIC}

\begin{tabular}{|c|c|c|c|c|c|c|}
\hline$\sim$ lat. N-S & Area & Marsh & Marg mar & Fjords & Shelf & Deep sea \\
\hline 70 & E Greenland & & & & & \\
\hline 73 & Arctic Canada & & & & & \\
\hline $50-43$ & Canada & & & & & \\
\hline $45-40$ & E USA & & & & & \\
\hline $40-25$ & E USA & & & & & \\
\hline 30 & N Gulf of Mexico & & & & & \\
\hline $25-18$ & S Gulf of Mexico & & & & & \\
\hline $18-12$ & Caribbean Sea & & & & & \\
\hline 5 & French Guiana & & & & & \\
\hline $24-31$ & Brazil & & & & & \\
\hline $38-54$ & Argentina & & & & & \\
\hline 58 & Scotia Sea & & & & & \\
\hline 67 & Weddell Sea & & & & & \\
\hline
\end{tabular}

Fig. 95. Trifarina fluens.

\section{NOTE ADDED IN PROOF}

After this paper had been accepted for publication and during the press editing phase, Andrew Gooday supplied the author with a pdf of the reference Gooday \& Jorissen (2012). This paper discusses various aspects of biogeography of deep sea foraminifera based on mainly presence/absence data for living and dead forms. It has useful discussion of the controls on deep-sea biogeographical patterns and on future issues.

\section{ACKNOWLEDGEMENTS}

Elisabeth Alve (University of Oslo, Norway) is thanked for encouragement, very helpful discussion and for reviewing the manuscript. The second referee, Sue Goldstein (University of Georgia, USA) also made helpful comments which led the author to avoid using the terms cosmopolitan and endemic. John Haynes provided thoughtful comments on lageninids. I thank the University of Southampton for the use of facilities and the Natural History Museum, London, for access to collections and libraries. The following kindly provided spreadsheets of data: Jean-Pierre Debenay, Francisco Fatela, Silvia Hess, Yvonne Milker, Dave Scott and Brent Wilson.

\section{Manuscript received 10 May 2012 Manuscript accepted 29 June 2012 \\ Scientific Editing by Bridget Wade}

\section{REFERENCES}

Ahrens, M.J., Graf, G. \& Altenbach, A.V. 1997. Spatial and temporal distribution of benthic foraminifera in the Northeast Water Polynya, Greenland. Journal of Marine Systems, 10: 445-465

Altenbach, A.V., Pflaumann, U., Schiebel, R., Thies, A., Timm, S. \& Trauth, M. 1999. Scaling percentages and distributional patterns of benthic foraminifera with flux rates of organic carbon. Journal of Foraminiferal Research, 29: 173-185.

Altenbach, A.V., Lutze, G.F., Schiebel, R. \& Schönfeld, J. 2003. Impact of interrelated and interdependent ecological controls on benthic foraminifera: An example from the Gulf of Guinea. Palaeogeography, Palaeoclimatology, Palaeoecology, 197: 213-238.

Alve, E. 1990. Variations in estuarine foraminiferal biofacies with diminishing oxygen conditions in Drammensfjord, SE Norway. In Hemleben, C., Kaminski, M.A., Kuhnt, W. \& Scott, D.B. (Eds), Paleoceanography and taxonomy of agglutinated foraminifera. Kluwer, Dordrecht, 661-694.

Alve, E. 1994. Opportunistic features of the foraminifer Stainforthia fusiformis (Williamson): Evidence from Frierfjord, Norway. Journal of Micropalaeontology, 13: 24.

Alve, E. 1995. Benthic foraminiferal distribution and recolonization of formerly anoxic environments in Drammensfjord, southern Norway. Marine Micropaleontology, 25: 169-186.

Alve, E. 1999. Colonization of new habitats by benthic foraminifera: A review. Earth-Science Reviews, 46: 167-185.

Alve, E. 2003. A common opportunistic foraminiferal species as an indicator of rapidly changing conditions in a range of environment. Estuarine, Coastal and Shelf Science, 57; 501-514.

Alve, E. 2010. Benthic foraminiferal response to absence of fresh phytodetritus: a two year experiment. Marine Micropaleontology, 76: 67-75.

Alve, E. \& Bernhard, J.M. 1995. Vertical migratory response of benthic foraminifera to controlled oxygen concentrations in an experimental mesocosm. Marine Ecology Progress Series, 116: 137-151.

Alve, E. \& Goldstein, S.T. 2003. Propagule transport as a key method of dispersal in benthic foraminifera. Limnology and Oceanography, 48 : 2163-2170.

Alve, E. \& Goldstein, S.T. 2010. Dispersal, survival and delayed growth of benthic foraminiferal propagules. Journal of Sea Research, 63: 36-51.

Alve, E. \& Murray, J.W. 1994. Ecology and taphonomy of benthic foraminifera in a temperate mesotidal inlet. Journal of Foraminiferal Research, 24: 18-27.

Alve, E. \& Murray, J.W. 1997. High benthic fertility and taphonomy of foraminifera: a case study of the Skagerrak, North Sea. Marine Micropaleontology, 31: 157-175.

Alve, E. \& Murray, J.W. 1999. Marginal marine environments of the Skagerrak and Kattegat: a baseline study of living (stained) benthic foraminiferal ecology. Palaeogeography, Palaeoclimatology, Palaeoecology, 146: 171-193.

Alve, E. \& Nagy, J. 1986. Estuarine foraminiferal distributions in Sandebukta, a branch of Oslo Fjord. Journal of Foraminiferal Research, 16: 261-284.

Alve, E., Murray, J.W. \& Skei, J. 2011. Deep-sea benthic foraminifera, carbonate dissolution and species diversity in Hardangerfjord, Norway: an initial assessment. Estuarine, Coastal and Shelf Science, 92: 90-102.

Anderson, S. 1994. Area and endemism. Quarterly Review of Biology, 69: 451-171.

Angel, M. 1995. Rarity: A biological conundrum. Ocean Challenge, 5: $8-9$.

Barmawidjaja, D.M., Jorissen, F.J., Puskaric, S. \& Van De Zwaan, G.J. 1992. Microhabitat selection by benthic foraminifera in the northern Adriatic Sea. Journal of Foraminiferal Research, 22: 297-317.

Barras, C., Fontanier, C., Jorissen, F. \& Hohenegger, J. 2010. A comparison of spatial and temporal variability of living benthic foraminiferal faunas at 550m depth in the Bay of Biscay. Micropaleontology, 56: 275-295.

Belasky, P. 1996. Biogeography of Indo-Pacific larger foraminifera and scleractinian corals: a probabilistic approach to estimating taxonomic diversity, faunal similarity, and sampling bias. Palaeogeography, Palaeoclimatology, Palaeoecology, 122: 119-141.

Berkeley, A., Perry, C.T., Smithers, S.G. \& Horton, B.P. 2008. The spatial and vertical distribution of living (stained) benthic foraminifera from a tropical, intertidal environment, north Queensland, Australia. Marine Micropaleontology, 69: 240-261.

Bernhard, J.M. 2000. Distinguishing live from dead foraminifera: methods review and proper applications. Micropaleontology, 46 (Suppl. 1): $38-46$. 
Bernhard, J.M. \& Bowser, S.S. 1999. Benthic foraminifera of dysoxic sediments: chloroplast sequestration and functional morphology. EarthScience Reviews, 46: 149-165.

Berthold, W.U. 1976. Test morphology and morphogenesis in Patellina corrugata Williamson. Journal of Foraminiferal Research, 6: 167-185.

Blanc-Vernet, L. 1969. Contribution à l'étude des Foraminifères de Méditerranée. Receuil des travaux de la station marine d'Endoume, $\mathbf{6 4}$ $1-281$.

Bubenshchikova, N., Nürnberg, D., Lembe-Jene, L. \& Pavlova, G. 2008. Living benthic foraminifera of the Okhotsk Sea: faunal composition, standing stock and microhabitats. Marine Micropaleontology, 69: 314-333.

Bugge, T., Befring, S., Belderson, R.H., Eidvin, T. \& Jansen, E. 1987. A giant three-stage slide off Norway. Geo-Marine Letters, 7: 191-198.

Buzas, M.A. 1965. The distribution and abundance of foraminifera in Long Island Sound. Smithsonian Miscellaneous Collections, 149: 1-89.

Buzas, M.A., Smith, R.K. \& Beem, K.A. 1977. Ecology and systematics of foraminifera in two Thalassia habitats, Jamaica, West Indies. Smithsonian Contributions to Paleobiology, 31: 1-139.

Buzas-Stephens, P. \& Buzas, M.A. 2005. Population dynamics and dissolution of foraminifera in Nueces Bay, Texas. Journal of Foraminiferal Research, 35: 248-258.

Buzas-Stephens, P., Buzas, M.A. \& Elliott, B.A. 2011. Foraminiferal population response to fluctuating inflow into Nueces Bay, Texas. Journal of Foraminiferal Research, 41: 14-21.

Cao, Y., Williams, D. \& Williams, N.E. 1998. How important are rare species in aquatic community ecology and bioassessment? Limnology and Oceanography, 43: 1403-1409.

Cearreta, A. 1988. Population dynamics of benthic foraminifera in the Santoña estuary, Spain. Revue de Paléobiologie, 2: 721-724.

Cearreta, A. 1989. Foraminiferal assemblages in the ria of San Vicente de la Barquera (Cantabria, Spain). Revista Española de Micropaleontología, 21: $67-80$

Collen, J.D. \& Newell, P. 1999. Fissurina as an ectoparasite. Journal of Micropalaeontology, 18: 110.

Cooper, W.C. 1961. Intertidal foraminifera of the California and Oregon coast. Contributions from the Cushman Foundation for Foraminiferal Research, 12: 47-63.

Culver, S.J. \& Buzas, M.A. 1999. Biogeography of neritic foraminifera. In Sen Gupta, B.K. (Ed.), Modern foraminifera. Kluwer, Dordrecht, 93-102.

Culver, S.J. \& Horton, B.P. 2005. Infaunal marsh foraminifera from the outer banks, North Carolina, USA. Journal of Foraminiferal Research, 35: $148-170$.

Cushman, J.A. 1922. The Foraminifera of the Atlantic Ocean, Part 3. Textulariidae. United States National Museum Bulletin, 104: 149pp.

Daniels, C.H. 1970. Quantitative ökologische Beobachtungenen an Foraminiferen im Limski kanal bei Rovinj/Jugoslawien (nördliche Adria). GöttingerArbeiten zur Geologie und Paläontologie, 8: 1-109.

Debenay, J.P. 2000. Foraminifers of tropical paralic environments. Micropaleontology, 46 (Suppl. 1): 153-160.

Debenay, J.P. \& Payri, C.E. 2010. Epiphytic foraminiferal assemblages on macroalgae in reefal environments of New Caledonia. Journal of Foraminiferal Research, 40: 36-60.

Debenay, J.P., Eichler, B.B., Bonetti, C. \& Coelho, C. 1996. Foraminifers, biomarkers in the mangrove swamps of Bertioga (Sao Paulo, Brazil). Anais da Reunião Especial da SBPC: Ecosistemas Costeiros - do conhecimento à gestao. SBPC, Florianopolis, 448pp.

Debenay, J.P., Guiral, D. \& Parra, M. 2002. Ecological factors acting on the microfauna in mangrove swamps. The case of foraminiferal assemblages in French Guiana. Estuarine, Coastal and Shelf Science, 55: 509-533.

Debenay, J.P., Guiral, D. \& Parra, M. 2004. Behaviour and taphonomic loss in foraminiferal assemblages of mangrove swamps of French Guiana. Marine Geology, 208: 295-314.
De Rijk, S.D. 1995. Salinity control on the distribution of salt marsh foraminifera (Great Marshes, Massachusetts). Journal of Foraminiferal Research, 25: 156-166.

De Rijk, S.D. \& Troelstra, S.R. 1999. The application of a foraminiferal actuo-facies model to salt marsh cores. Palaeogeography, Palaeoclimatology, Palaeoecology, 149: 59-66.

Diz, P., Francés, G., Costas, S. \& Alejo, I. 2004. Distribution of benthic foraminifera in coarse sediments, Ría de Vigo, NW Iberian margin. Journal of Foraminiferal Research, 34: 258-275.

Donnici, S. \& Serandrei Barbero, R. 2002. The benthic foraminiferal communities of the northern Adriatic continental shelf. Marine Micropaleontology, 44: 93-123.

Duchemin, G., Jorissen, F., Andieux-Loyer, F., Le Loc'h, F., Hily, C. \& Phillipon, X. 2005. Living benthic foraminifera from 'La Grande Vasière', French Atlantic continental shelf: Faunal composition and microhabitats. Journal of Foraminiferal Research, 35: 198-218.

Duchemin, G., Fontanier, C., Jorissen, F.J., Barras, C. \& Griveaud, C. 2007. Living small-sized $(63-150 \mu \mathrm{m})$ foraminifera from mid-shelf to mid-slope environments in the Bay of Biscay. Journal of Foraminiferal Research, 37: 12-32.

Duleba, W. \& Debenay, J.P. 2003. Hydrodynamic circulation in the estuaries of Estação ecológica Juréa-Itiatins, Brazil, inferred from the foraminifera and thecamoebian assemblages. Journal of Foraminiferal Research, 33: 62-93.

Eichler, B.B., Debenay, J.P., Bonetti, C. \& Duleba, W. 1995. Répartition des foraminifères benthiques dans le zone sud-ouest du système estuarien-lagunaire d'Iguape-Cananéia (Brésil). Boletim do Instituto Oceaográfico de USP, São Paulo, 43: 1-17.

Ellison, R.L. \& Murray, J.W. 1987. Geographical variation in the distribution of certain agglutinated foraminifera along the North Atlantic margins. Journal of Foraminiferal Research, 17: 123-131.

Erbacher, J. \& Nelskamp, S. 2006. Comparison of benthic foraminifera inside and outside a sulphur-oxidizing bacterial mat from the present oxygen-minimum zone off Pakistan (NE Arabian Sea). Deep-Sea Research. I, 53: 751-756.

Fatela, F., Moreno, J., Moreno, F. et al. 2009. Environmental constraints of foraminiferal assemblages distribution across a brackish tidal marsh (Caminha, NW Portugal). Marine Micropaleontology, 70: 70-88.

Feyling-Hanssen, R.W. 1964. Foraminifera in Late Quaternary deposits from the Oslofjord area. Norges Geologiske Untersökelse, 225: 1-383.

Finlay, B.J. 2002. Global dispersal of free-living microbial eukaryote species. Science, 296: 1061-1063.

Fontaneto, D. 2011. Biogeography of Microscopic organisms. Is Everything Small Everywhere? Cambridge University Press, Cambridge, 365pp.

Fontanier, C., Jorissen, F.J., Licari, L., Alexandre, P., Anschutz, P. \& Carbonel, P. 2002. Live benthic foraminiferal faunas from the Bay of Biscay: faunal density, composition, and microhabitats. Deep-Sea Research I, 49: 751-785.

Fontanier, C., Jorissen, F.J., Chaillou, G., David, C., Anschutz, P. \& Lafon, V. 2003. Seasonal and interannual variability of benthic foraminiferal faunas as $550 \mathrm{~m}$ depth in the Bay of Biscay. Deep-Sea Research. I, 50: 457-494.

Fontanier, C., Jorissen, F.J., Chailou, G., Anschutz, P., Gremare, A. \& Giveaud, C. 2005. Live foraminiferal faunas from a $2800 \mathrm{~m}$ deep lower canyon station from the Bay of Biscay: faunal response to focussing of refractory organic matter. Deep-Sea Research. I, 52: 1189-1227.

Fontanier, C., Jorissen, F., Anschutz, P. \& Chaillou, G. 2006. Seasonal variability of benthic foraminiferal faunas at $1000 \mathrm{~m}$ depth in the Bay of Biscay. Journal of Foraminiferal Research, 36: 61-76.

Fontanier, C., Jorissen, F., Geslin, E., Zaragosi, S., Duchemin, G., Laversin, M. \& Gaultier, M. 2008a. Live and dead foraminiferal faunas from Saint-Tropez Canyon (Bay of Fréjus): observations based on in situ incubated cores. Journal of Foraminiferal Research, 38: 137-156. 
Fontanier, C., Jorissen, F.J., Lansard, B. et al. 2008b. Live foraminifera from the open slope between Grand Rhône and Petit Rhône Canyons (Gulf of Lions, NW Mediterranean). Deep-Sea Research I, 55: $1532-1553$.

Forwick, M., Vorren, T.O., Hald, M. et al. 2010. Spatial and temporal influence of glaciers and rivers on the sedimentary environment in Sassenfjorden and tempelfjorden, Spitsbergen. In Howe, J.A., Austin, W.E.N., Korsun, S. \& Paetzel, M. (Eds), Fjord Systems and Archives. Geological Society, London, Special Publications, 344: 163-193.

Frontalini, F. \& Coccioni, R. 2008. Benthic foraminifera from heavy metal pollution monitoring: a case study from the central Adriatic coast of Italy. Estuarine, Coastal and Shelf Science, 76: 404-417.

Frontalini, F., Busi, C., Da Pelo, S., Coccioni, R., Cherchi, A. \& Bucci, C. 2009. Benthic foraminifera as bio-indicators of trace element pollution in the heavily contaminated Santa Gilla lagoon (Cagliari, Italy). Marine Pollution Bulletin, 58: 858-877.

Gaston, K.J. 1997. What is rarity? In Kunin, W.E. \& Gaston, K.J. (Eds), The Biology of Rarity. Causes and Consequences of Rare-common Differences. Chapman \& Hall, London, 31-47.

Gilpin, M.E. \& Soulé, M.E. 1986. Minimum viable populations: processes of species extinction. In Soulé, M.E. (Ed.), Conservation Biology: the Science of Scarcity and Diversity. Sinauer, Sunderland, USA, 19-34.

Goldstein, S.T. 1999. Foraminifera: a biological overview. In Sen Gupta, B.K. (Ed.), Modern Foraminifera. Kluwer, Dordrecht, 37-55.

Goldstein, S. \& Alve, E. 2011. Experimental assembly of foraminiferal communities from coastal propagule banks. Marine Ecology Progress Series, 437: 1-11.

Goldstein, S.T. \& Harben, E.B. 1993. Taphonomic implications of infaunal foraminiferal assemblages in a Georgia salt marsh, Sapelo Island. Micropaleontology, 39: 53-62.

Gooday, A.J. 2002. Biological responses to seasonally varying fluxes of organic matter to the ocean floor: a review. Journal of Oceanography, 58: $305-332$.

Gooday, A.J. \& Jorissen, F.J. 2012. Benthic foraminiferal biogeography: controls on global distribution patterns in deep-water settings. Annual Review of Marine Science, 4: 237-262. http://dx.doi.org/10.1146/ annurev-marine-120709-142737

Graf, G. 2003. Ecosystem functioning and biodiversity: bioengineering. In Wefer, G., Lamy, F. \& Mantoura, F. (Eds), Marine Science Frontiers for Europe. Springer-Verlag, Berlin, 243-250.

Grassle, J.F. \& Sanders, H. 1973. Life histories and the role of disturbance. Deep-Sea Research, 20: 643-659.

Griveaud, C., Jorissen, F. \& Anschutz, P. 2010. Spatial variability of live benthic foraminiferal faunas on the Portuguese margin. Micropaleontology, 56: 297-322.

Hald, M. \& Korsun, S. 1997. Distribution of modern benthic foraminifera from fjords of Svalbard, European Arctic. Journal of Foraminiferal Research, 27: 101-122.

Harloff, J. \& Mackensen, A. 1997. Recent benthic foraminiferal associations and ecology of the Scotia Sea and Argentine Basin. Marine Micropaleontology, 31: 1-29.

Haward, N.J.B. \& Haynes, J.R. 1976. Chlamys opercularis as a mobile substrate for foraminifera. Journal of Foraminiferal Research, 6: 30-38.

Hayek, L.C. \& Buzas, M.A. 2010. Surveying Natural Populations. Quantitative Tools for Assessing Biodiversity (2nd edn). Columbia University Press, New York, 590pp.

Haynes, J.R. 1973. 1973. Cardigan Bay Recent foraminifera (Cruises of R.V. Antur, 1962-1964). Bulletin of the British Museum (Natural History) Zoology, Suppl. 4, 245pp.

Haynes, J.R. 1981. Foraminifera. MacMillan, London, 433pp.

Hayward, B.W., Holzmann, M., Grenfell, H.R., Pawlowski, J. \& Triggs, C.M. 2004. Morphological distinction of molecular types in Ammonia - towards a taxonomic revision of the world's most commonly misidentified foraminifera. Marine Micropaleontology, 50: 237-271.
Heinz, P., Ruscmeier, W. \& Hemleben, C. 2008. Living benthic foraminiferal assemblages at the Pacific continental margin of Costa Rica and Nicaragua. Journal of Foraminiferal Research, 38: 215-227.

Heip, C., Brandt, A., Gattuso, J.P. et al. 2003. Ecosystem functioning and biodiversity. In Wefer, G., Lamy, F. \& Mantoura, F. (Eds), Marine Science Frontiers for Europe. Springer-Verlag, Berlin, 289-302.

Hess, S. \& Jorissen, F.J. 2009. Distribution patterns of living benthic foraminifera from Cap Breton Canyon, Bay of Biscay: faunal response to sediment instability. Deep-Sea Research I, 56: 1555-1578.

Hess, S., Jorissen, F.J., Venet, V. \& Abu-Zied, R. 2005. Benthic foraminiferal recovery after recent turbidite deposition in Cap Breton Canyon, Bay of Biscay. Journal of Foraminiferal Research, 35: 114-129.

Höglund, H. 1947. Foraminifera in the Gullmar Fjord and the Skagerak. Zoologiska Bidrag från Uppsala, 26: 1-328.

Hohenegger, J., Pillar, W. \& Baal, C. 1989. Reasons for spatial microdistributions of foraminifera in an intertidal pool (northern Adriatic Sea). PSZNI, Marine Ecology, 10: 43-78.

Hubbell, S.P. 2001. The Unified Neutral Theory of Biodiversity and Biogeography. Princeton University Press, Princeton, 375pp.

Husum, K. \& Hald, M. 2004. Modern foraminiferal distribution in the subarctic Malangen Fjord and adjoining shelf, northern Norway. Journal of Foraminiferal Research, 34: 34-48.

Ikeya, N. 1970. Population ecology of benthonic foraminifera in Ishikari Bay, Hokkaido, Japan. Records of Oceanographic Works in Japan, 10: 173-191.

Ivanova, E.V., Ovsepyan, E.A., Risebrobakken, B. \& Vetrov, A.A. 2008. Downcore distribution of living calcareous foraminifera and stable isotopes in the western Barents Sea. Journal of Foraminiferal Research, 38: $337-356$.

Kitazato, H., Shiramaya, Y., Nakatsuka, T. et al. 2000. Seasonal phytodetritus deposition and responses of bathyal benthic foraminiferal populations in Sagami Bay, Japan: preliminary results from "Project Sagami" 1996-1999. Marine Micropaleontology, 40: 135-149.

Klitgaard-Kristensen, D. \& Sejrup, H.P. 1996. Modern benthic foraminiferal facies across the northern North Sea. Sarsia, 81: 97-106.

Knight, R. \& Mantoura, R.F.C. 1985. Chlorophyll $a$ and carotenoid pigments in foraminifera and their symbiotic algae: analysis in high-performance liquid chromatography. Marine Ecology Progress Series, 23: 241-249.

Koho, K.A., Kouwenhoven, T.J., De Stigter, H.C. \& Van Der Zwaan, G.J. 2007. Benthic foraminifera in the Nazare Canyon, Portguese continental margin: sedimentary environments and disturbance. Marine Micropaleontology, 66: 27-51.

Korsun, S. \& Hald, M. 1998. Modern benthic foraminifera off Novaya Zemlya tidewater glaciers. Arctic and Alpine Research, 30: 61-77.

Korsun, S. \& Hald, M. 2000. Seasonal dynamics of benthic foraminifera in a glacially fed fjord of Svalbard, European arctic. Journal of Foraminiferal Research, 30: 251-271.

Kunin, W.E. 1997. Introduction: on the causes and consequences of rarecommon differences. In Kunin, W.E. \& Gaston, K.J. (Eds), The Biology of Rarity. Causes and Consequences of Rare-common Differences. Chapman \& Hall, London, 3-11.

Langer, M. 2000. Comparative molecular analysis of small-subunit ribosomal 18s DNA sequences from Haynesina germanica (Ehrenberg, 1840), a common intertidal foraminifer from the North Sea. Neues Jahrbuch für Geologie und Paläontologie, 11: 641-650.

Langer, M.R., Hottinger, L. \& Huber, B. 1989. Functional morphology in low-diverse benthic foraminiferal assemblages from tidal flats in the North Sea. Senckenbergiana Maritima, 20: 81-99.

Lankford, R.R. \& Phleger, F.P. 1973. Foraminifera from the nearshore turbulent zone, western North America. Journal of Foraminiferal Research, 3: 101-132.

Le Calvez, J. 1947. Entosolenia marginata (Walker and Boys), foraminifère apogamique ectoparasite d'une autre foraminifère: Discorbis villardeboanus (d'Orbigny). Comptes rendus hebdomadaire des séances de l'Academie des Sciences, Paris, 224: 1448-1450. 
Le Campion, J. 1970. Contribution á l'étude des foraminifères du Bassin d'Arcachon et du proche océan. Bulletin Institute Géologique du Bassin Aquitaine, 8: 3-98.

Lee, A.J. \& Ramster, J.W. 1981. Atlas of the seas around the British Isles. Ministry of Agriculture, Fisheries and Food, Lowestoft, England. Not paginated.

Lee, J.J. 1980. Nutrition and physiology of the foraminifera. In Levandowsky, M. \& Hunter, S.H. (Eds) Biochemistry and Physiology of Protozoa (2nd edn), Academic Press, New York, 3: 43-66.

Lee, J.J., Muller, W.A., Stone, R.J., McEnery, M.E. \& Zucker, W. 1969. Standing crop of foraminifera in sublittoral epiphytic communities of a Long Island salt marsh. Marine Biology, 4: 44-61.

Lesen, A.E. 2005. Relationship between benthic foraminifera and food resources in South San Francisco Bay, California, USA. Marine Ecology Progress Series, 297: 131-145.

Licari, L.N., Schumacher, S., Wenzhöfer, F., Zabel, M. \& Mackensen, A. 2003. Communities and microhabitats of living benthic foraminifera from the tropical east Atlantic: impact of different productivity regimes. Journal of Foraminiferal Research, 33: 10-31.

Linke, P. \& Lutze, G.F. 1993. Microhabitat preferences of benthic foraminifera: a static concept or a dynamic adaptation to optimise food acquisition? Marine Micropaleontology, 20: 215-234.

Lipps, J.H. \& DeLaca, T.E. 1980. Shallow-water foraminiferal ecology, Pacific Ocean. In Field, M.E., Bouma, A.H. et al (Eds), Quaternary Depositional Environments of the Pacific Coast, Pacific Coast Paleogeography Symposium. Society of Economic Paleontologists and Mineralogists, 325-340.

Lister, J.J. 1895. Contributions to the life-history of the Foraminifera. Philosophical Transactions of the Royal Society, B186: 401-453.

Loeblich, A.R. \& Tappan, H. 1987. Foraminiferal genera and their classification. Van Nostrand Reinhold, New York, 1: 970pp, 2: 212pp.

Ludwick, J.C. \& Walton, W.R. 1957. Shelf-edge, calcareous prominences in northeastern Gulf of Mexico. Bulletin of the American Association of Petroleum Geologists, 41: 2054-2101.

Lueck, K.L.O. \& Snyder, S.W. 1997. Lateral variations among populations of stained benthic foraminifera in surface sediments of the North Carolina continental shelf (U.S.A.). Journal of Foraminiferal Research, 27: $20-41$.

Lutze, G.F. 1980. Depth distribution of benthic foraminifera on the continental margin off NW Africa. "Meteor" Forschungs-Ergebnisse, Reihe C, 32: 31-80.

Lutze, G.F., Mackensen, A. \& Wefer, G. 1983. Foraminiferen der Kieler Bucht, 2. Salinitätsansprüche von Eggerella scabra (Williamson). Meyniana, 35: 55-65.

Maas, M. 2000. Verteilung lebendgefärbter benthischer Foraminiferen in einer intensivierten Sauerstoffminimumzone, Indo-Pakistanischer Kontintalrand, nördlisches Arabisches Meer. Meyniana, 52: 101-129.

Mackensen, A. 1985. Verbreitung und Umwelt Benthische Foraminiferen in der Norwegischen See. Kiel University, 126pp.

Mackensen, A. \& Douglas, R.G. 1989. Down-core distribution of live and dead deep-water benthic foraminifera in box cores from the Weddell Sea and California continental borderland. Deep-Sea Research, 36: 879-900.

Mackensen, A., Fütterer, D.K., Grobe, H. \& Schmiedl, G. 1993. Benthic foraminiferal assemblages from the South Atlantic Polar Front region between 35 and $57^{\circ} \mathrm{S}$ : distribution, ecology and fossilization potential. Marine Micropaleontology, 22: 33-69.

Mackensen, A., Schmiedl, G., Harloff, J. \& Giese, M. 1995. Deep-sea foraminifera in the South Atlantic Ocean. Micropaleontology, 41: 342358.

Matera, N.J. \& Lee, J.J. 1972. Environmental factors affecting the standing crop of foraminifera in sublittoral and psammolittoral communities of a Long Island salt marsh. Marine Biology, 14: 89-103.

McCann, K.S. 2000. The diversity-stability debate. Nature, 405: 228-233.
McCormick, J.M., Severin, K.P. \& Lipps, J.H. 1994. Summer and winter distribution of foraminifera in Tomales Bay, northern California. Cushman Foundation for Foraminiferal Research, Special Publication, 32: 69-101.

Milker, Y., Schmiedl, G., Betzler, C., Römer, M., Jaramillo-Vogel, D. \& Siccha, M. 2009. Distribution of recent foraminifera in shelf carbonate environments of the Western Mediterranean Sea. Marine Micropaleontology, 73: 207-225.

Mojtahid, M., Jorissen, F., Lansard, B., Fontanier, C., Bombled, B. \& Rabouille, C. 2009. Spatial distribution of live benthic foraminifera in the Rhône prodelta: faunal response to a continental-marine organic matter gradient. Marine Micropaleontology, 70: 177-200.

Mojtahid, M., Griveaud, C., Fontanier, C., Anschutz, P. \& Jorissen, F.P. 2010. Live benthic foraminiferal faunas along a bathymetric transect (180-4800m) in the Bay of Biscay (NE Atlantic). Revue de Micropaléontologie, 53: 139-162.

Moodley, L. 1990. Southern North Sea seafloor and subsurface distribution of living benthic foraminifera. Netherlands Journal of Sea Research, 27: 51-71.

Morvan, J., Debenay, J.P., Jorissen, F.J. et al. 2006. Patchiness and life cycle of intertidal foraminifera: implications for environmental and palaeoenvironmental interpretation. Marine Micropaleontology, 61: 131-154.

Murosky, M.W. \& Snyder, S.W. 1994. Vertical distribution of stained benthic foraminifera in sediments of southern Onslow Bay, North Carolina continental shelf. Journal of Foraminiferal Research, 24: 158-170.

Murray, J.W. 1968. The living Foraminiferida of Christchurch Harbour, England. Micropaleontology, 14: 83-96.

Murray, J.W. 1980. The Foraminifera of the Exe Estuary. Devonshire Association Special Volume, 2: 89-115.

Murray, J.W. 1983. Population dynamics of benthic foraminifera: results from the Exe estuary, England. Journal of Foraminiferal Research, 13: 1-12.

Murray, J.W. 1991. Ecology and palaeoecology of benthic foraminifera. Harlow, Longman, 397pp.

Murray, J.W. 1992. Distribution and population dynamics of benthic foraminifera from the southern North Sea. Journal of Foraminiferal Research, 22: 114-128.

Murray, J.W. 2003. Foraminiferal assemblage formation in depositional sinks on the continental shelf margin west of Scotland. Journal of Foraminiferal Research, 33: 101-121.

Murray, J.W. 2006. Ecology and Applications of Benthic Foraminifera. Cambridge University Press, Cambridge, 426pp.

Murray, J.W. 2007. Biodiversity of living benthic foraminifera: how many species are there?. Marine Micropaleontology, 64: 163-176.

Murray, J.W. \& Alve, E. $2000 a$. Major aspects of foraminiferal variability (standing crop and biomass) on a monthly scale in an intertidal zone. Journal of Foraminiferal Research, 30: 177-191.

Murray, J.W. \& Alve, E. 2000b. Do calcareous dominated shelf foraminiferal assemblages leave worthwhile ecological information after their dissolution? In Hart, M.B. Kaminski, M.A. \& Smart, C. (Eds), Proceedings of the Fifth International Workshop on Agglutinated Foraminifera, Plymouth England, September 1997. Grzybowski Foundation Special Publication, 7: 311-331.

Murray, J.W. \& Alve, E. 2002. Benthic foraminifera as indicators of environmental change: marginal marine, shelf and upper slope environments. In Haslett, S.K. (Ed.), Quaternary Environmental Micropalaeontology. Arnold, London, 59-90.

Murray, J.W. \& Alve, E. 2011. The distribution of agglutinated foraminifera in NW European seas: baseline data for the interpretation of fossil assemblages. Palaeontologia Electronica, 14(2): 14A 41p: palaeo-electronica.org.2011_2/248/index.html.

Murray, J.W. \& Bowser, S.S. 2000. Mortality, protoplasm decay rate, and reliability of staining techniques to recognise 'living' foraminifera: a review. Journal of Foraminiferal Research, 30: 66-77. 
Myers, E.H. 1935a. The life history of Patellina corrugata Williamson a foraminifer. Bulletin of the Scripps Institution of Oceanography, Technical Series, 3: 355-392.

Myers, E.H. 1935b. Morphogenesis of the test and the biological significance of dimorphism in the foraminifer, Patellina corrugata Williamson. Bulletin of the Scripps Institution of Oceanography, Technical Series, $\mathbf{3}$ : 393-404.

Myers, E.H. 1936. The life-cycle of Spirillina vivipara Ehrenberg with notes on morphogenesis, systematics and distribution of the foraminifera. Journal of the Royal Microscopical Society, 66: 120-146.

Nardelli, M., Jorissen, F.J., Pusceddu, A. et al. 2010. Living benthic foraminiferal assemblages along a latitudinal transect at $1000 \mathrm{~m}$ depth off the Portuguese margin. Micropaleontology, 56: 323-344.

Orbigny, A.d'. 1839. Formainifèves. In R. de la Sagna (Ed), Histoire physique politique et naturelle de L'Ile de Cuva, Paris, Artus Bertrand, 224 pp.

Ozarko, D.L., Patterson, R.T. \& Williamsn, H.F.L. 1997. Marsh foraminifera from Nanaimo, British Columbia (Canada): implications of infaunal habitat and taphonomic biasing. Journal of Foraminiferal Research, 27: 51-68.

Pavlyuk, O.N., Tarasova, T.S. \& Trebukhova, Y.A. 2008. Foraminifera and Nematoda within the area of Ahnfeltia tobuchiensis Field in Stark Strait (Peter the Great Bay of the Sea of Japan). Russian Journal of Marine Biology, 34: 151-158.

Pawlowski, J. \& Holzmann, M. 2008. Diversity and geographic distribution of benthic foraminifera: a molecular perspective. Biodiversity and Conservation, 17: 317-328.

Pawlowski, J., Fahrni, J., Lecroq, D. et al. 2007. Bipolar gene flow in deep-sea benthic foraminifera. Molecular Ecology, 16: 4089-4096.

Phleger, F.P. 1951. Ecology of foraminifera, northwest Gulf of Mexico. Part 1. Foraminiferal distribution. Geological Society of America, Memoir, 46: 1-88.

Phleger, F.P. 1956. Significance of living foraminiferal populations along the central Texas coast. Contributions from the Cushman Foundation for Foraminiferal Research, 7: 106-151.

Phleger, F.P. 1966. Patterns of living marsh foraminifera in South Texas coastal lagoons. Boletin de la Sociedad Geologica Mexicana, 28: $1-44$.

Phleger, F.P. \& Lankford, R.R. 1978. Foraminiferal and ecological processes in the Alvarado Lagoon area, Mexico. Journal of Foraminiferal Research, 8: 127-131.

Phleger, F.B. \& Parker, F.L. 1951. Ecology of foraminifera, northwest Gulf of Mexico. Part II Foraminiferal species. Geological Society of America Memoir, 46: 1-64.

Poag, C.W., Knebel, H.J. \& Todd, R. 1980. Distribution of modern benthic foraminifers on the New Jersey outer continental shelf. Marine Micropaleontology, 5: 43-69.

Polovodova, I., Nikulina, A., Schönfeld, J. \& Dullo, W.C. 2009. Recent benthic foraminifera in the Flensburg Fjord (Western Baltic Sea). Journal of Micropalaeontology, 28: 131-142.

Rabinowitz, D. 1981. Seven forms of rarity. In Synge, H. (Ed.), The Biological Aspects of Plant Conservation. John Wiley, Chichester, 205-217.

Rathburn, A.E., Levin, L.A., Held, Z. \& Lohmann, K.C. 2000. Benthic foraminifera associated with cold methane seeps on the northern California margin: ecology and stable isotopic compositions. Marine Micropaleontology, 38: 247-266.

Saffert, H. \& Thomas, E. 1998. Living foraminifera and total populations in salt marsh peat cores: Kelsey marsh (Clinton, CT) and the Great Marshes (Barnstable, MA). Marine Micropaleontology, 33: 175-202.

Schafer, C.T. 1982. Foraminiferal colonization of an offshore dump site in Chaleur Bay, New Brunswick, Canada. Journal of Foraminiferal Research, 12: 317-326.

Schafer, C.T. \& Young, J.A. 1977. Experiments on mobility and transportability of some nearshore benthonic foraminifera species. Geological Survey of Canada, Paper 99-1C: 27-31.
Schmiedl, G., Mackensen, A. \& Müller, P.J. 1997. Recent benthic foraminifera from the eastern South Atlantic Ocean; dependence on food supply and water masses. Marine Micropaleontology, 32: 221-230.

Schmiedl, G., De Bovée, F., Buscail, R. et al. 2000. Trophic control of benthic foraminiferal abundance and microhabitat in the bathyal Gulf of Lions, western Mediterranean. Marine Micropaleontology, 40: $167-188$.

Schönfeld, J. 2001. Benthic foraminifera and pore-water oxygen profiles: a re-assessment of species boundary conditions at the western Iberian margin. Journal of Foraminiferal Research, 31: 86-107.

Schönfeld, J. 2012. History and development of methods of Recent benthic foraminiferal studies. Journal of Micropalaeontology, 31: 53-72.

Schönfeld, J. \& Numberger, L. 2007. The benthic foraminiferal response to the 2004 spring bloom in the western Baltic Sea. Marine Micropaleontology, 65: 78-95.

Schönfeld, J., Dullo, W.C., Pfannkucke, O. et al. 2011. Recent benthic foraminiferal assemblages in the Porcupine Seabight. Facies, 57: $187-213$.

Schweizer, M., Polovodova, I., Nikulina, A. \& Schönfeld, J. 2011. Molecular identification of Ammonia and Elphidium species (Foraminifera, Rotaliida) from the Kiel Fjord (SW Baltic Sea) with rDNA sequences. Helgoland Marine Research, 65: 1-10. DOI 10.1007/ s10152-010-0194-3.

Scott, D.B. \& Medioli, F. 1980. Quantitative studies of marsh foraminiferal distribution in Nova Scotia: implications for sea level studies. Contributions from the Cushman Foundation for Foraminiferal research, Special Publication, 17: 1-58.

Scott, D.B., Medioli, F.S. \& Schafer, C.T. 1977. Temporal changes in foraminiferal distributions in Miramichi River estuary, New Brunswick. Canadian Journal of Earth Sciences, 14: 1566-1587.

Scott, D.B., Piper, D.J.W. \& Panagos, A.G. 1979. Recent salt marsh and intertidal mudflat foraminifera from the western coast of Greece. Rivista Italiana de Paleontologia, 85: 243-266.

Scott, G.A., Scourse, J.D. \& Austin, W.E.N. 2003. The distribution of benthic foraminifera in the Celtic Sea: the significance of seasonal stratification. Journal of Foraminiferal Research, 33: 32-61.

Seiglie, G.A. 1974. Foraminifers of Mayagüez and Añasco Bays and its surroundings. Caribbean Journal of Science, 14: 1-58.

Semeniuk, T.A. 2001. Epiphytic foraminifera along a climatic gradient, Western Australia. Journal of Foraminiferal Research, 31: 191-200.

Sen Gupta, B.K. 1971. The benthonic foraminifera of the tail of the Grand Banks. Micropaleontology, 17: 69-98.

Simpson, J.H. \& Sharples, J. 2012. Introduction to Physical and Chemical Oceanography of Shelf Seas. Cambridge University Press, Cambridge, p. 11.

Smart, C.W. \& Gooday, A.J. 2006. Benthic foraminiferal trends in relation to an organic enrichment gradient on the continental slope (850 $\mathrm{m}$ water depth) off North Carolina (USA). Journal of Foraminiferal Research, 36: 34-43.

Southall, K.E., Gehrels, W.R. \& Hayward, B.W. 2006. Foraminifera in a New Zealand salt marsh and their suitability as sea-level indicators. Marine Micropaleontology, 60: 167-179.

Steineck, P.L. \& Bergstein, J. 1979. Foraminifera from Hommocks salt-marsh, Larchmont Harbor, New York. Journal of Foraminiferal Research, 9: 147-158.

Sturrock, S. \& Murray, J.W. 1981. Comparison of low energy middle shelf foraminiferal faunas. Celtic Sea and Western English Channel. In Neale, J.W. \& Brasier, M.D. (Eds), Microfossils from Recent and fossil shelf seas. Ellis Horwood, Chichester, 250-260.

Szarek, R., Kuhnt, W., Kawanura, H. \& Kitazato, H. 2006. Distribution of recent benthic foraminifera on the Sunda Shelf (South China Sea). Marine Micropaleontology, 61: 171-195.

Szarek, R., Kuhnt, W., Kawanura, H. \& Nishi, H. 2009. Distribution of recent benthic foraminifera along continental slope of the Sunda Shelf (South China Sea). Marine Micropaleontology, 71: 41-159. 
Thompson, L.B. 1978. Distribution of living benthic foraminifera, Isla de los Estados, Tierra del Fuego, Argentina. Journal of Foraminiferal Research, 8: 241-257.

Tobin, R., Scott, D.B., Collins, E.S. \& Medioli, F. 2005. Infaunal benthic foraminifera in some North American marshes and their influence on fossil assemblages. Journal of Foraminiferal Research, 35: 130-147.

Tsujimoto, A., Nomura, R., Yasuhara, M. \& Yoshikawa, S. 2006. Benthic foraminiferal assemblages in Osaka Bay, southwestern Japan: faunal changes over the last 50 years. Paleontological Research, 10: 141-161.

Uchio, T. 1960. Ecology of living benthonic foraminifera from the San Diego, California, area. Cushman Foundation for Foraminiferal Research, Special Publication, 5: 1-72.

Van Der Zwaan, G.J. 1982. Paleoecology of late Miocene Mediterranean foraminifera. Utrecht Micropaleontological Bulletins, 25: 1-201.

Walton, W.R. 1952. Techniques for recognition of living foraminifera. Contributions from the Cushman Foundation for Foraminiferal Research, 3: 56-60.
Wefer, G. 1976. Environmental effects on growth rates of benthic foraminifera (shallow water, Baltic Sea). Maritime Sediments, Special Publication, 1: 39-50.

Weinberg, J.R. 1991. Rates of movement and sedimentary traces of deep-sea foraminifera and Mollusca in the laboratory. Journal of Foraminiferal Research, 21: 213-217.

Williamson, W.C. 1848. On the recent species of the genus Lagena. Annals and Magazine of Natural History, series 2: 1-20.

Williamson, W.C. 1858. Recent Foraminifera of Great Britain. Ray Society, London, 100pp.

Wilson, B. 2007. Guilds of epiphytal foraminifera on fibrous substrates, Nevis, West Indies. Marine Micropaleontology, 63: 1-18.

Wilson, B. \& Ramsook, A. 2007. Population densities and diversities of epiphytal foraminifera on nearshore substrates, Nevis, West Indies. Journal of Foraminiferal Research, 37: 213-222.

Wollenburg, J.E. \& Mackensen, A. 1998. On the vertical distribution of the living (rose Bengal stained) benthic foraminifers in the Arctic Ocean. Journal of Foraminiferal Research, 28: 268-285. 